San Jose State University

SJSU ScholarWorks

Master's Theses

Master's Theses and Graduate Research

Fall 2016

\title{
Structure and Volcanic Evolution of the Northern Highland Range, Colorado River Extensional Corridor, Clark County, Nevada
}

Ryan A. McKee

San Jose State University

Follow this and additional works at: https://scholarworks.sjsu.edu/etd_theses

\section{Recommended Citation}

McKee, Ryan A., "Structure and Volcanic Evolution of the Northern Highland Range, Colorado River Extensional Corridor, Clark County, Nevada" (2016). Master's Theses. 4768.

DOI: https://doi.org/10.31979/etd.c3qe-pa69

https://scholarworks.sjsu.edu/etd_theses/4768

This Thesis is brought to you for free and open access by the Master's Theses and Graduate Research at SJSU ScholarWorks. It has been accepted for inclusion in Master's Theses by an authorized administrator of SJSU ScholarWorks. For more information, please contact scholarworks@sjsu.edu. 

NEVADA

\author{
A Thesis \\ Presented to \\ The Faculty of the Department of Geology \\ San José State University \\ In Partial Fulfillment \\ of the Requirements for the Degree \\ Master of Science
}

by

Ryan A. McKee

December 2016 
(C) 2016

Ryan A. McKee

ALL RIGHTS RESERVED 
The Designated Committee Approves the Thesis Titled

STRUCTURE AND VOLCANIC EVOLUTION OF THE NORTHERN HIGHLAND RANGE, COLORADO RIVER EXTENSIONAL CORRIDOR, CLARK COUNTY, NEVADA

by

Ryan A. McKee

APPROVED FOR THE DEPARTMENT OF GEOLOGY

SAN JOSE STATE UNIVERSITY

December 2016

Dr. Jonathan Miller

Dr. Robert Miller

Dr. Ellen Metzger
Department of Geology

Department of Geology

Department of Geology 


\section{ABSTRACT \\ STRUCTURE AND VOLCANIC EVOLUTION OF THE NORTHERN HIGHLAND RANGE, COLORADO RIVER EXTENSIONAL CORRIDOR, CLARK COUNTY, NEVADA \\ by Ryan A. McKee}

A geologic map was drafted of the northern Highland Range (1:24,000 scale), rock units defined, and samples of the volcanic units were obtained and analyzed to produce a representative suite of chemical analyses to characterize the range of geochemical variability. The style, relative timing, and orientation of faults and dikes, and the magnitude and variability of stratal tilting was examined to evaluate the structural and magmatic evolution of the northern Highland Range in the context of models for the Colorado River Extensional Corridor and Black Mountains accommodation zone. Methods involved field mapping of the range scale structure and geometry of faulting, structural interpretation, and geochemical analysis of ten representative samples by X-ray spectrometry. Structural data was interpreted with stereonets; geochemical whole rock, and major elemental data was analyzed by comparing elemental oxides; trace elemental data was analyzed by normalizing to chondrite concentrations. The northern Highland Range is a ca. 3,000 m-thick sequence of volcanic and volcaniclastic flows and breccias overlain by regionally extensive tuffs (Mt. Davis and Bridge Spring). Unique mineralogy, geochemistry and lithologic character of some units and volcanic vent facies, as well as the presence of domes and dikes feeding the extrusives argue for local derivation from a dome/stratocone volcanic complex that was mostly restricted to the northern Highland Range. 


\section{ACKNOWLEDGEMENTS}

This thesis is the culmination of years of hard work, marking a time of professional and personal growth. I wish to thank all the faculty and staff of the San Jose State Department of Geology, for their love of geology is infectious and inspiring.

Thesis research was primarily funded through a grant from the National Cooperative Geologic Mapping Program EDMAP (10HQPA0004).

Many fellow SJSU geology students (Rachel Unger, Brent Johnson, Jon Sanchez, Chris Scudder, and Capt. Brendon Johnson), friends (James Bellenger, Adam Loveridge, and Chris Isaacs), and my father Roy McKee assisted me in the field, asking invaluable questions and making many enjoyable memories.

Much appreciation and thanks to Jim Faulds for his foundational work in the region and for his insight in the field.

Extensive copy editing was provided by Ryan Miller.

Thank you to my thesis advisor, Professor Jonathan Miller for great direction, and committee members, Professors Richard Sedlock (proposal stage), Ellen Metzger (completion stage), and Bob Miller.

I wish to also thank my friends and family who have supported me through this academic journey, with special thanks to Bert and Dale Dollahite, my parents Jan and Roy McKee, and my ever encouraging and amazing wife, Courtney M. McKee. 


\section{TABLE OF CONTENTS}

LIST OF FIGURES....................................................... viii

INTRODUCTION............................................................ 1

Geologic Setting.................................................. 3

Research Objectives and Rational.................................. 5

GEOLOGIC UNIT DESCRIPTIONS AND STRATIGRAPHY ........................ 8

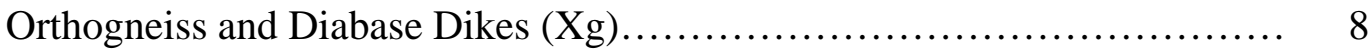

Basal Trachyandesite of the Highland Range (Thbb).................... 12

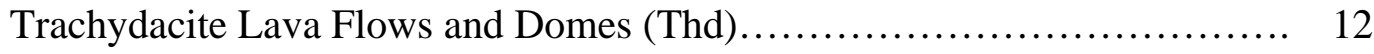

Volcanics of the Highland Range: Trachyandesite Flows and Volcanic

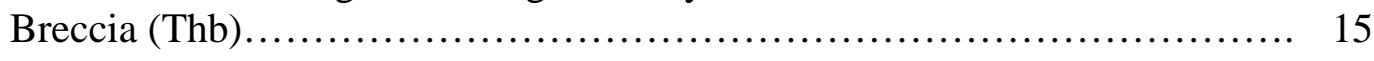

Volcanic Breccia: Lithic Tuff and Debris flows (Tvb).................. 18

Trachyandesite and Trachydacite Dikes (Thbi)...................... 23

Tuff of Bridge Spring and Tuff of Mount Davis (Tb/Tdt)................ 24

Neogene (Tertiary) Conglomerate (Tc) $\ldots \ldots \ldots \ldots \ldots \ldots \ldots \ldots \ldots \ldots \ldots \ldots . \ldots \ldots$

Quaternary Alluvium, Fan, and Debris Flow Deposits (Qal)............... 27

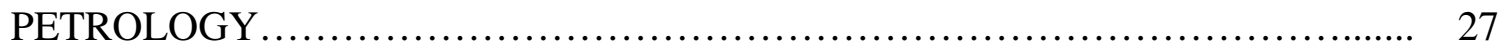

Petrography/Thin Sections....................................... 27

Whole Rock Analysis........................................... 28

Major Elements........................................... 29

Trace Elements............................................ 38

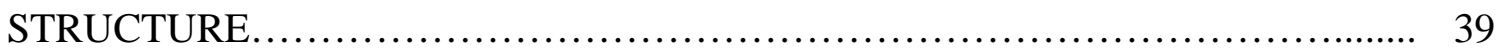




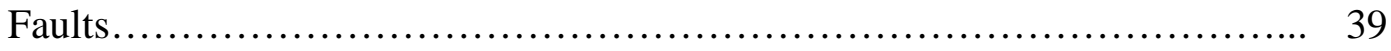

Fault Zones..................................................... 42

Orientation of Strata.................................................. 45

Dikes and Vents ..................................................... 47

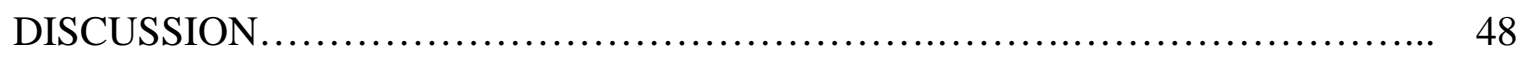

Volcanic Stratigraphy, Facies Relationships and Correlation................ 48

Petrologic Comparisons to Highland Range Rocks and Surrounding

Areas...................................................................... 61

Structure.................................................................. 67

Faulting.......................................................... 67

Tilting and Extension.............................................. 69

Relationship of the Northern Highland Range to the Black Mountains

Accommodation Zone and Lake Mead Extensional Domain....................... 72

Fault and Dike Interaction...................................... 74

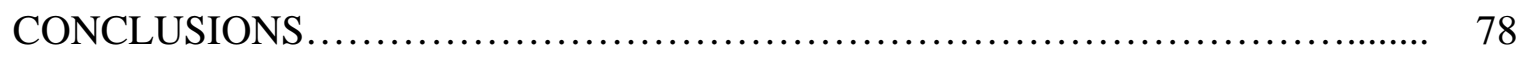

REFERENCES CITED...................................................... 81

APPENDIX A: Photomicrographs................................................ 105

APPENDIX B: Tables......................................................... 114

PLATE 1. GEOLOGIC MAP OF THE NORTHERN HIGHLAND RANGE

PLATE 2. CROSS SECTIONS OF THE NORTHERN HIGHLAND RANGE 


\section{LIST OF FIGURES}

Figure 1. Generalized geologic map of the Northern Colorado River extensional corridor...

Figure 2. Geologic map of the northern, central, and southern Highland Range........ 4

Figure 3. Block diagram of major faults within the central Highland Range showing anticline and syncline formed in an extensional setting................. 5

Figure 4. Stratigraphic column of the northern Highland Range.................. 9

Figure 5. View of the northern Highland Range looking south.................... 10

Figure 6. Outcrop of regionally extensive basement orthogneiss................. 11

Figure 7. Outcrop of hematite stained Trachydacite (Thd) $\ldots \ldots \ldots \ldots \ldots \ldots \ldots \ldots \ldots \ldots \ldots$

Figure 8. Trachydacite breccia domes (Thd) along the western flank of the northern Highland Range............................................ 14

Figure 9. View of the western flank of the main central ridge.................... 15

Figure 10. View of eastern flank of the main ridge........................... 16

Figure 11. Cliff face exposure of lava and autobreccia.......................... 17

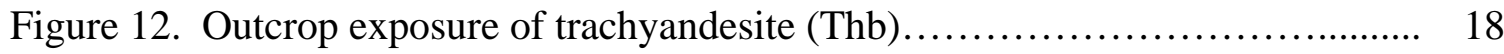

Figure 13. East tilted sequences of lava and volcanic breccia..................... 19

Figure 14. Tapering lava flow within volcanic breccia........................... 20

Figure 15. Outcrop exposure of typical volcanic breccia $(\mathrm{Tvb}) \ldots \ldots \ldots \ldots \ldots \ldots \ldots \ldots .21$

Figure 16. Detail of laminations in volcanic breccia........................... 22

Figure 17. Volcanic bomb within volcanic breccia............................. 22

Figure 18. North-striking dike and faults................................. 23

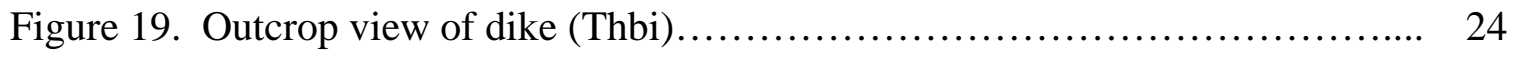


Figure 20. Pitting and replacement in thin section view.......................... 29

Figure 21. TAS plot of samples from the northern Highland Range................ 30

Figures 22a through 22n. Harker diagrams of major and trace oxides.............. 31-37

Figure 23. Trace element normalization diagram for northern Highland Range volcanic rocks normalized to chondrite............................... 38

Figure 24. REE normalized to Chondrite from the northern Highland Range.......... 39

Figure 25. Stereonet plot of east-dipping faults.................................. 40

Figure 26. Stereonet plot of west-dipping faults................................ 41

Figure 27. Northern Highland Range fault map................................ 43

Figure 28. North-striking faults of domain one................................ 44

Figure 29. Stereonet plot of bedding........................................ 46

Figure 30. Stereonet comparing upper and lower east-dipping bedding attitudes..... 47

Figure 31. Dikes and faults on the northeast side of the map area.................. 48

Figure 32. Stereonet of poles to dikes................................................................... 49

Figure 33. Trachyandesite dike or plug....................................... 50

Figure 34. Interactions of lava flows and volcanic breccia.......................................... 54

Figure 35A and 35A. Trachyte domes within Tvb................................. 56

Figure 36. Deformed trachyte lavas within volcanic breccia........................ 58

Figure 37. Stratigraphic Column of the northern, central, and southern Highland Range...........................................................

Figure 38. Cartoon cross section of the northern, central, and southern Highland Range.

Figure 39. TAS plot of samples from the northern Highland Range and regionally adjacent volcanics. 
Figure 40. Trace elements of the northern Highland Range and Nelson SW Quadrangle.

Figure 41. Trace elements of the northern Highland Range and surrounding local units.

Figure 42. REE of the northern Highland Range and surrounding local areas........ 66

Figure 43. Stereonet of faults in relation to zone.............................. 68

Figure 44. Schematic and simplified three-dimensional block diagram showing possible faulting relationships in the northern Highland Range............................. 74

Figure 45. Fault and dike orientations of the northern Highland Range.................... 75

Figure 46. Major faults of zone 1 and associated dikes....................................... 76

Figure 47. Stereonet of dike orientations......................................................... 77 


\section{INTRODUCTION}

The Colorado River Extensional Corridor of southern Nevada, southeastern California, and western Arizona is an area of large-magnitude Miocene extension and broadly syn-extensional magmatism within the southern Basin and Range province (Howard and John, 1987). Magmatism and extension in the Colorado River Extensional Corridor are the culmination of time-transgressive north to south and south to north sweeps of extension and magmatism across the western Cordillera during the Oligocene and Miocene (Christiansen and Yeats, 1992; Wernicke, 1992; Harlan et al., 1998; Faulds et al., 2001).

The axis of the Colorado River Extensional Corridor runs along the Colorado River from the Lake Mead area through the southern tip of Nevada, and extends over a region from 70 to $100 \mathrm{~km}$ wide (Fig. 1). Blocks of upper crust exposing 1 to 3-km-thick sections of Tertiary volcanic rocks, basin-filling volcaniclastic and sedimentary rocks, and Miocene plutons are moderately- to steeply-tilted along high- and low-angle normal faults that sole into major detachment faults (Howard and John, 1987; Bachl et al., 2001;

Faulds et al., 1990; 1995; 2001; 2002a; Feuerbach et al., 1993; Miller and Miller, 2002; Metcalf, 2004; Walker et al., 2007). The volcanic and sedimentary rocks lie nonconformably on Proterozoic gneiss that is intruded by Tertiary plutons and dikes; in some cases, the plutons intrude only slightly older volcanic sections (Bachl et al., 2001). Strata are rotated from $30^{\circ}$ to $90^{\circ}$ with most dips greater than $60^{\circ}$ (Faulds et al., 1995; 2002a). 


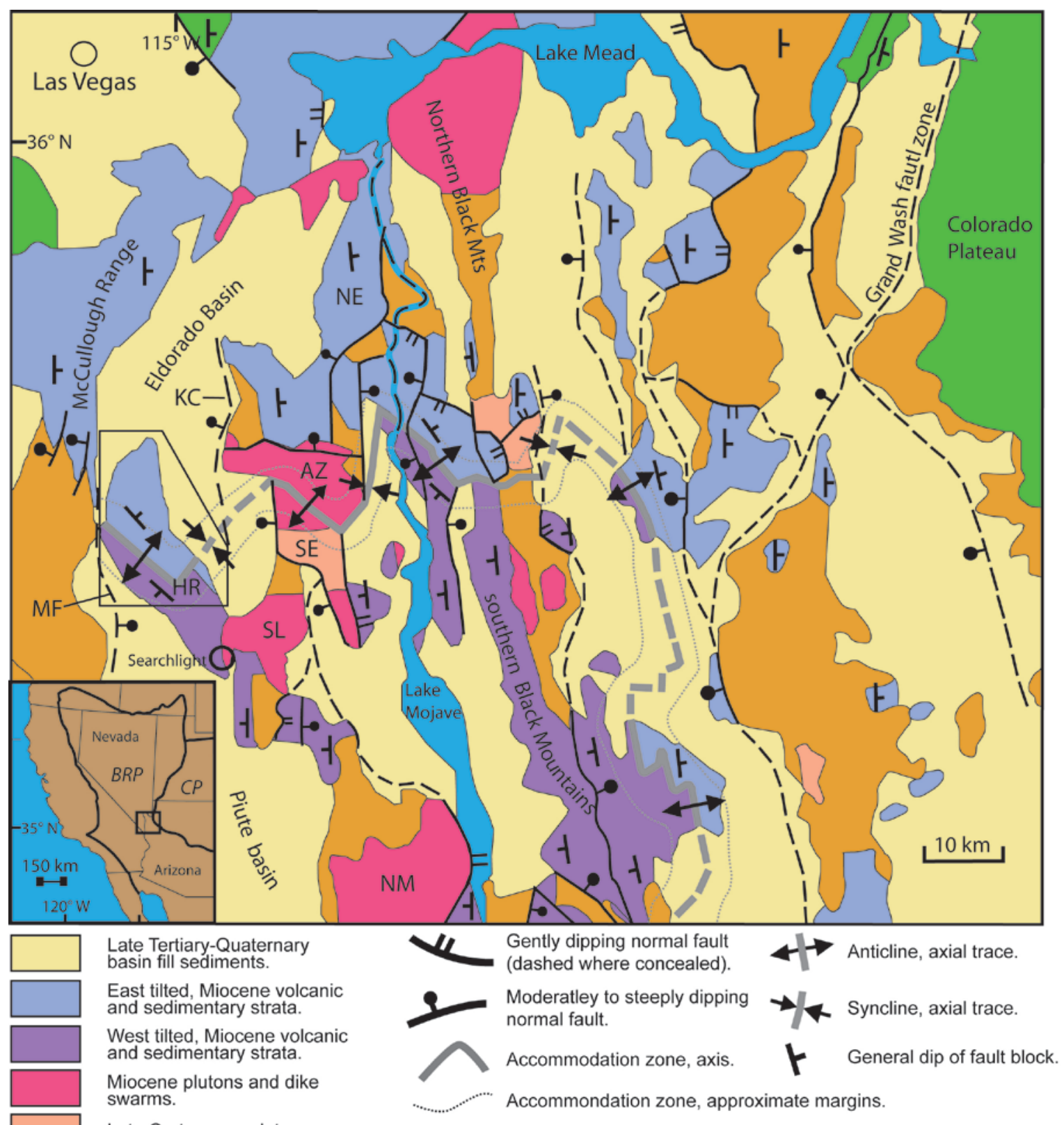

Late Cretaceous plutons.

Paleozoic sedimentary strata.

Proterozoic plutonic and metamorphic rock.

BRP, Basin and Range Province (inset); AZ, Aztec Wash pluton; $\mathrm{CP}$, Colorado Plateau (inset); HR, Highland Range; MF McCullough Fault; NE, northern Eldorado Mountains; NM, Newberry Mountains; SE, southern Eldorado Mountains; SL, Searchlight pluton.

Figure 1. Generalized geologic map of the Northern Colorado River extensional corridor. The box surrounds the map area in the Highland Range, which is shown in more detail in Plate 1. Figure is modified from Faulds et al. (2001). 


\section{Geologic Setting}

The Highland Range is important to the structural evolution of the Colorado River Extensional Corridor because it occurs at the western edge of the Black Mountains accommodation zone, a zone of complex, extension-related folding that stretches from the southern Black Mountains in western Arizona to the Highland Range (Fig. 1). Faulds and Varga (1998) delineated the boundaries of the Black Mountains accommodation zone based on the variations in regional tilting of strata within the Colorado River Extensional Corridor. Normal faults to the north of the accommodation zone (Lake Mead domain) are west-dipping and cause tilting of volcanic and volcaniclastic strata to the east and northeast. South of the accommodation zone (Whipple Mountain domain), normal faults are east-dipping and tilt strata consistently to the west (Faulds and Varga, 1998).

Within the Highland Range, the accommodation zone manifests itself as an extensional syncline and anticline formed by tilting and rotation of strata on oppositely dipping normal faults that terminate opposite each other (Figs. 2 and 3).

To the north of the axis of the accommodation zone, west-dipping normal faults are inferred to sole in to a few possible faults, but most likely the Grand Wash fault zone (Fig. 1). South of the accommodation zone, east-dipping normal faults sole to the McCullough Range fault that is exposed just to the west of the Highland Range (Faulds et al., 2001) (Fig. 1). The northern Highland Range lies in a fortuitous location to examine the structural relationships and relation of magmatism and structure at the western termination of the Black Mountains accommodation zone. 


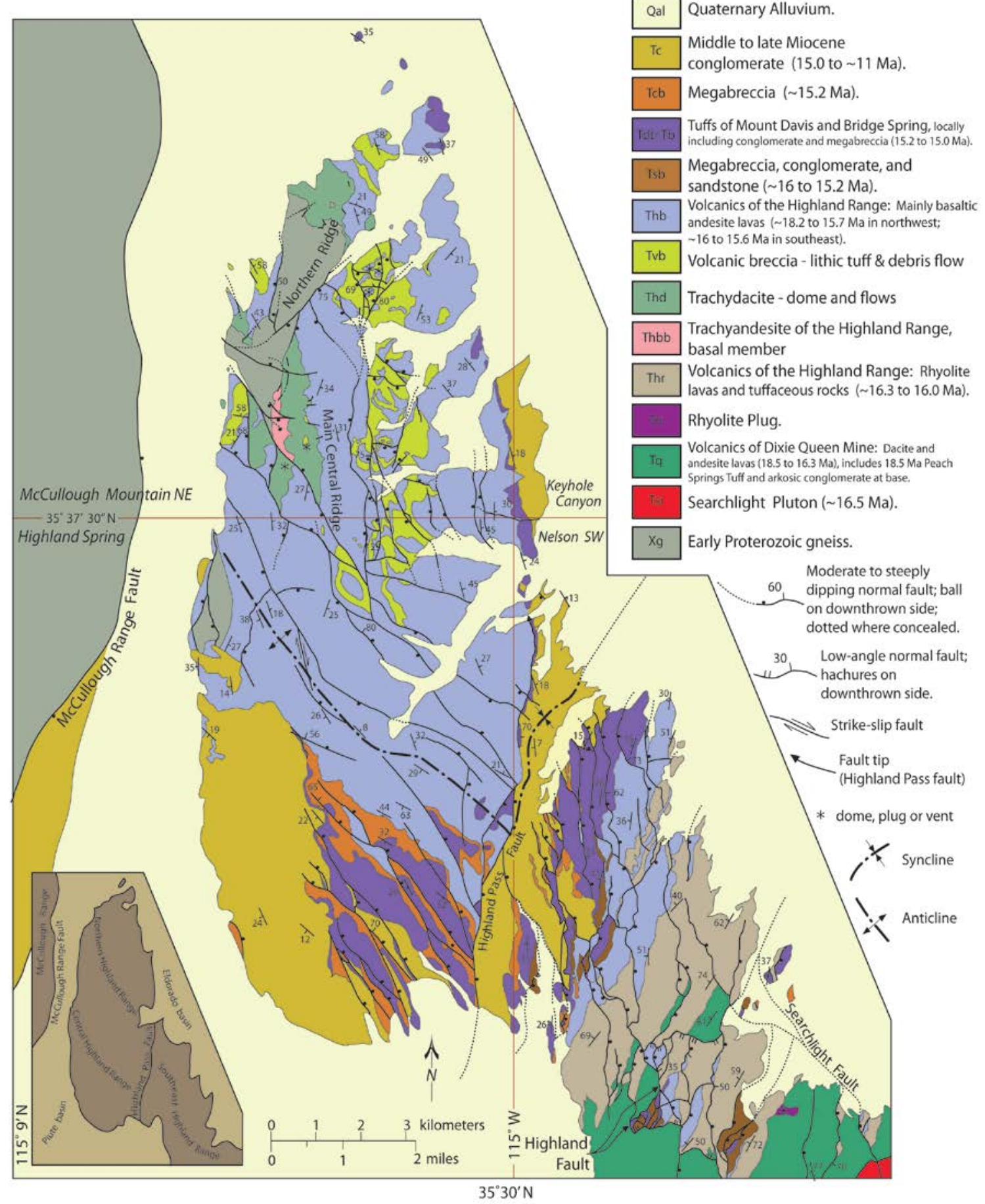

Figure 2. Geologic map of the northern, central, and southern Highland Range. Figure is modified from Faulds et al. (2002a). 


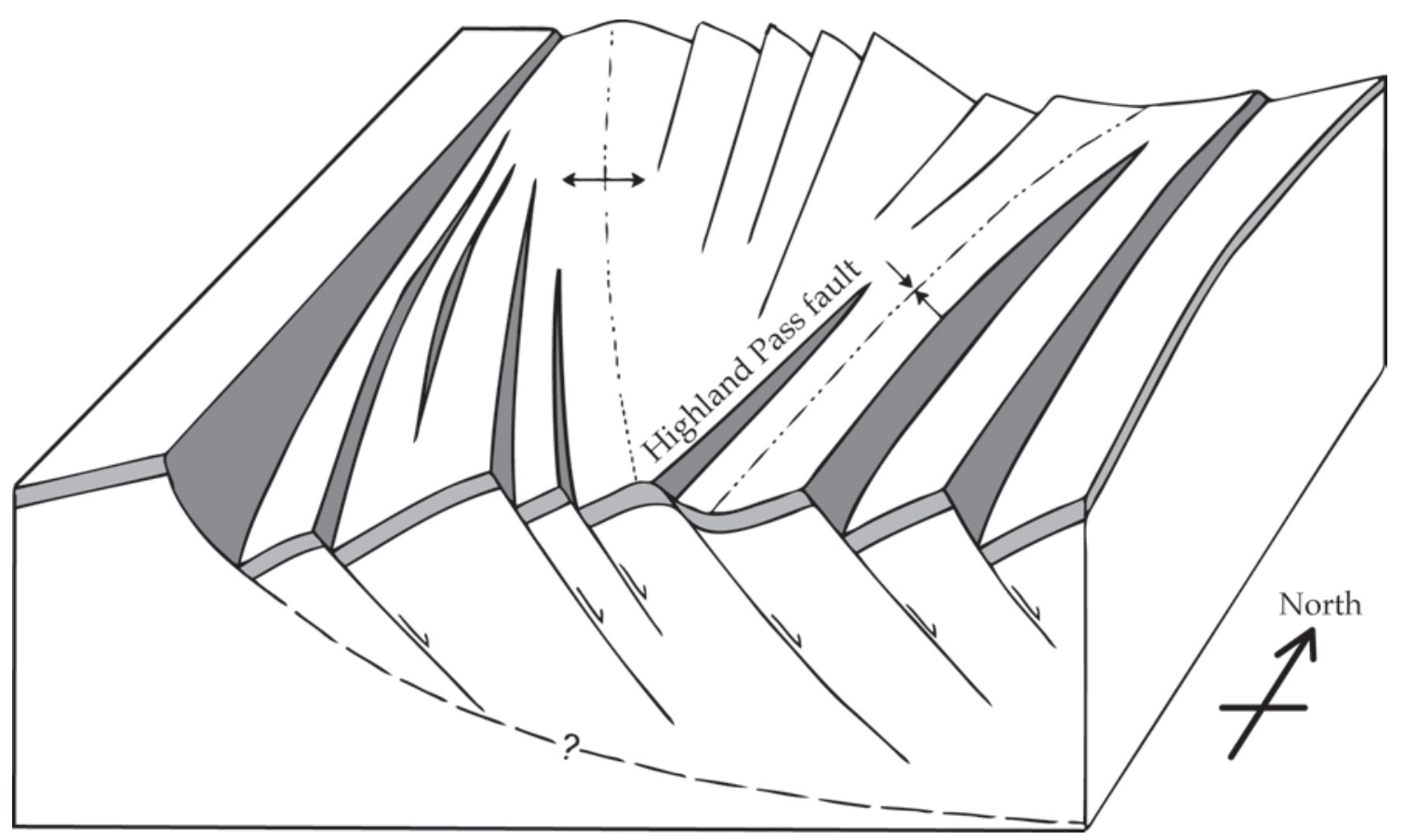

Figure 3. Block diagram of major faults within the central Highland Range showing anticline and syncline formed in an extensional setting. The Lake Mead domain lies north of the axis of the anticline and syncline, while the east-dipping faults within the Whipple Mountain domain lie to the south. Faults are hypothesized to sole to the McCullough Range fault that acts as a detachment. Figure is modified from Faulds et al. (2002a).

\section{Research Objectives and Rationale}

The general structural evolution and petrology of the Northern Highland Range has up until the present study remained largely unknown. The specific research objectives were to:

1. Make a geologic map at 1:24,000 scale of the northern Highland Range, including complete petrographic and field characterization of the rock units comprising the map area. The majority of the map (approximately 75\%) occurs within of the McCullough Range NE 7.5 minute USGS topographic quadrangle. The eastern, southern, and 
southeast corner of the map area come from the Keyhole Canyon, Highland Spring, and Nelson SW 7.5 minute USGS topographic quadrangles, respectively (Fig. 2).

2. Determine the vent sources of volcanic units in the map area if possible and obtain a representative suite of chemical analyses to characterize the range of geochemical variability within the volcanic rocks.

3. Examine the style, relative timing, and orientation of faults and dikes, and the magnitude and variability of stratal tilting.

4. Evaluate the structural and magmatic evolution of the northern Highland Range in the context of models for the Colorado River Extensional Corridor and Black Mountains accommodation zone.

Detailed geologic mapping in the northern Highland Range focused on the rangescale structure and geometry of faulting to understand how it relates to structures farther to the south within the accommodation zone.

Faulds et al. (2002a) showed that volcanic and sedimentary rocks filling halfgrabens, and concurrently development of fault arrays, and folding within and to the south of the accommodation zone were generally coeval with extensional deformation. In detail, extension appears to have initiated and the rate appears to have increased during eruption of the rhyolitic sequence in the southern Highland Range, as shown by dates of volcanic strata and shallowing of tilts within the stratigraphy. The complexity of faulting appears generally to decrease from the south to north, but faults and changes in stratal tilts north of the accommodation zone in the central and especially the northern Highland Range are poorly known. In addition, dikes up to 5 meters thick 
and continuous for $>1 \mathrm{~km}$ along strike are useful for constraining the orientation of extensional stresses in the area.

The stratigraphy throughout the Highland Range consists of volcanic and intercalated sedimentary rocks, which have significant along-strike variability (Faulds et al., 2002a; 2004). Faulds et al. (2002a) suggested that the basaltic trachyandesite and trachyandesite flows that comprise most of the central Highland Range strata have a source in the northern Highland Range. This is based on the thickening of the lava flow sequence from $35 \mathrm{~m}$ to close to $1200 \mathrm{~m}$ toward the north. However, reconnaissance of the northern Highland Range shows that in addition to the trachyandesite sequences, an appreciable quantity of lithic-rich tuff is present in the strata—enough to possibly constitute a significant pulse of felsic magmatism. Davis (1984) first described this tuff unit in her thesis and noted that it thickened toward the north, but its overall areal extent and volume remain unknown. Silicic lavas and tuffs locally constitute a significant fraction (up to $1 / 3$ ) of the stratigraphy of the southern Highland Range (Faulds et al., 2002a; 2004). Whether the lithic tuffs in the northern Highland Range can be tied to silicic magmatism in the southern Highland Range is not yet clear, but is important to establish through mapping, stratigraphic correlation, and geochemical analysis, because if related, these units may indicate a more widespread pulse of broadly contemporaneous, extension-related felsic magmatism.

Finding the volcanic sources/centers to the volcanic rocks in the northern Highland Range will also better illuminate the regional stratigraphy, provide a more complete picture of the areal distribution of magmatic centers, and present a more 
complete petrogenetic record that could be compared to the central and southern exposures in the Highland Range.

\section{GEOLOGIC UNIT DESCRIPTIONS AND STRATIGRAPHY}

The mapped area of the northern Highland Range consists of more than 3,000 m of predominantly intermediate lavas and numerous intercalated autobreccias, and lithicrich volcanic breccias overlying Precambrian orthogneiss (Fig. 2). Based on broadly correlative regional strata, the strata comprising the northern Highland Range are inferred to be early Miocene. The volcanic and volcaniclastic section is capped by the regionally recognized Tuffs of Bridge Spring (15.21 Ma) and Mt. Davis (15.00 Ma) (Faulds et al., 2002a). Intermediate dikes intrude through the entire volcanic sequence, but are not observed within or above the Tuffs of Bridge Spring or Mt. Davis. Capping Neogene to Holocene alluvial/fluvial conglomerates (0 to $400 \mathrm{~m}$ ) lie unconformably above the volcanic strata and thicken toward the basin axes (Fig. 4).

\section{Orthogneiss and Diabase Dikes (Xg)}

Early Proterozoic orthogneiss comprises the basement of the northern Highland Range, and is exposed along the western flank and northern end of the range (Plate 1). The orthogneiss exposures form cliffs up to 8-10 m high, but topography is generally subdued, in comparison to areas dominated by volcanic exposures (Fig. 5). Outcrops of orthogneiss are greenish gray, gray, and white with prominent cm-scale gneissic banding (Fig. 6). The orthogneiss is comprised of orthoclase, plagioclase, quartz, biotite, and hornblende, with trace amounts of garnet and rare muscovite. A biotite defined foliation 


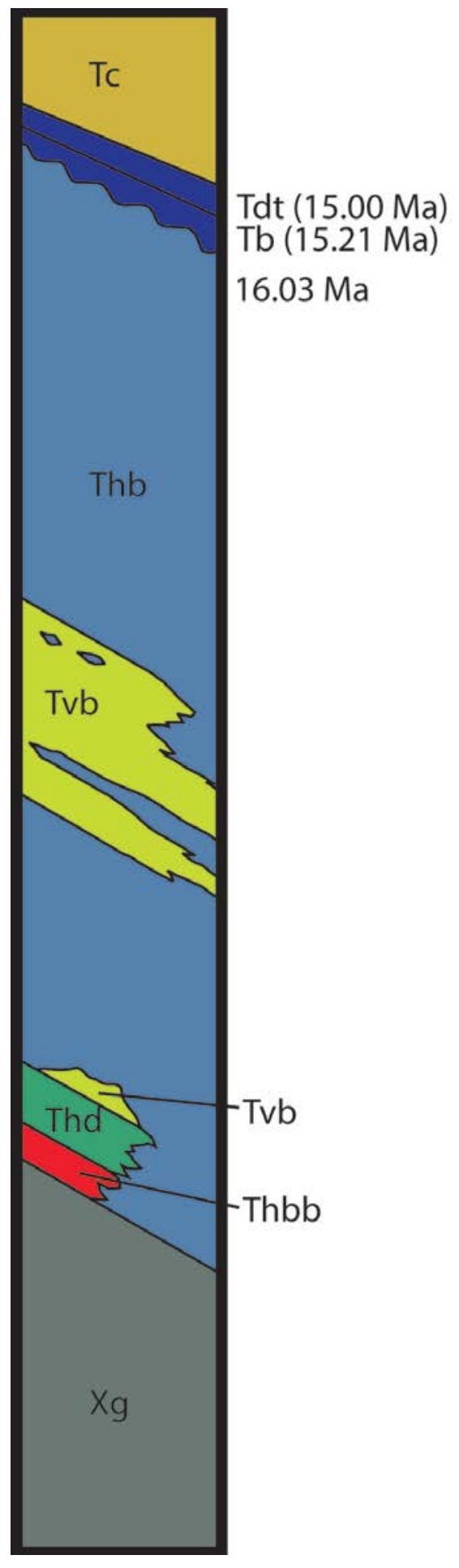

Figure 4. Stratigraphic column of the northern Highland Range. Geologic unit labels are explained in Figure 2. Dates in parenthesis from the central Highland Range. Figure is modified from Faulds et al., (2002a). Column represents approximately $5000 \mathrm{~m}$ of strata. 


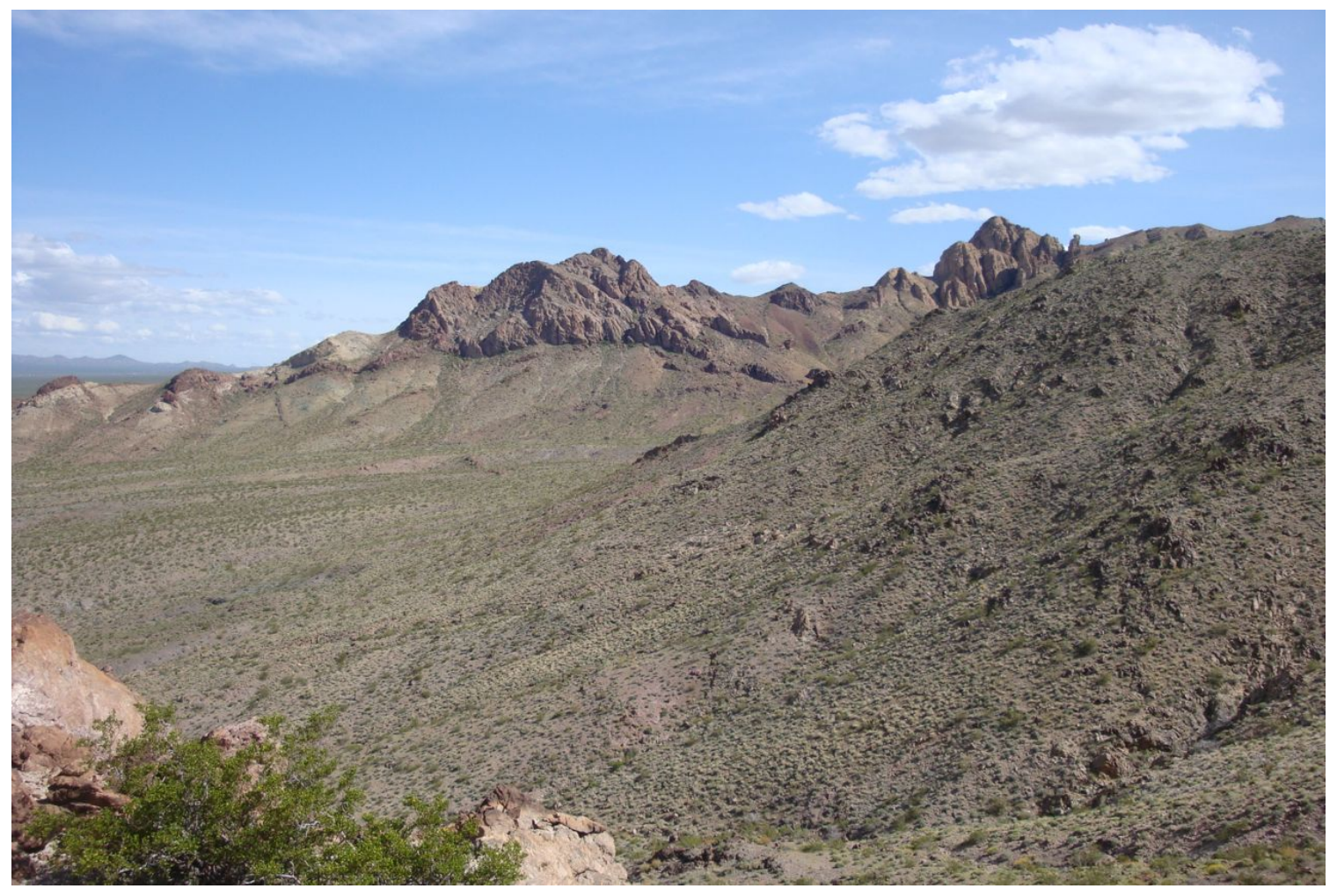

Figure 5. View of the northern Highland Range looking south. Precambrian orthogneiss hill in mid-view on right side of photograph. Orthogneiss slopes are generally less steep and topography is more subdued when compared to areas of volcanic breccia and cliffforming trachyandesite in distance.

varies from northeast- to northwest-striking, and moderate to steeply dipping with local (several meter square) domains of weak to absent deformation. Precambrian orthogneiss underlies Miocene volcanic and sedimentary rocks elsewhere within the region (Anderson, 1971; Davis, 1984; Neilson and Beratan, 1990). The orthogneiss unit in the northern Highland Range is correlated to similar orthogneiss found in the McCullough Range just to the west of the northern Highland Range. In the southern McCullough Range, similar orthogneiss has been dated at 1.71 Ga (Wooden and Miller, 1990).

Conspicuous lobate and lenticular dark green-gray diabase dikes are found locally; they are particularly well exposed along the western flank of the range in close 


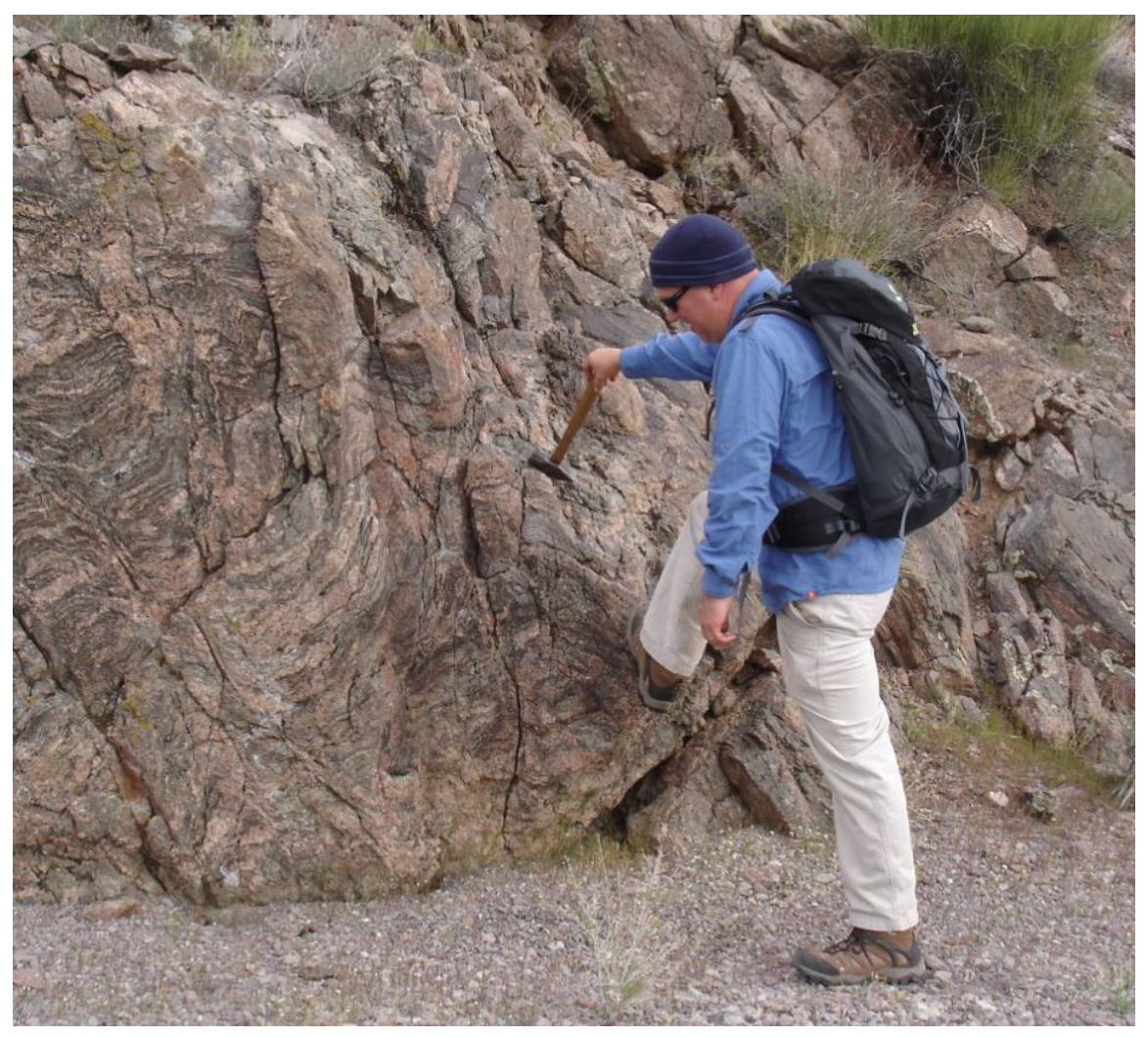

Figure 6. Outcrop of regionally extensive basement orthogneiss. Orthogneiss varies between felsic and mafic mineral concentrations with biotite prominently observed in this outcrop.

proximity to a highly faulted area within the orthogneiss $(3948000 \mathrm{~m} \mathrm{~N}, 676000 \mathrm{~m}$ E, all UTM in grid $11 \mathrm{~S}$ on NAD 83 Datum). Usually only 1-2 m thick and less than $20 \mathrm{~m}$ long, the dikes lack visible crystals. Pyroxene, plagioclase, and olivine are present in hand sample and commonly replaced by secondary minerals. In thin section, feldspar microlites and Fe-Ti oxides dominate the matrix. Similar diabase dikes of Mesoproterozoic age are found throughout Proterozoic granite and gneiss in southeastern California and Arizona (Howard, 1991). Dikes within the northern Highland Range are likely correlative. 


\section{Basal Trachyandesite of the Highland Range (Thbb)}

Dark brown, black, purple-gray, and dark gray trachyandesite flows (3 to 8 flows), approximately 10 to $60 \mathrm{~m}$ thick, are found along the western flank of the main north-striking ridge within the map area (Plate 1) (Fig. 4). Associated autobreccia horizons within the flow sequence, separating the individual flows, are gray where relatively fresh to orange-red where oxidized. The flows comprising the unit are sparsely porphyritic (5-20\%); phenocrysts are dominantly plagioclase and minor clinopyroxene but pseudomorphs of biotite and amphibole are also present and replaced by Fe-Ti oxides and secondary calcite. Thin section photomicrographs are presented in Appendix A. The trachyandesite lies nonconformably on the Proterozoic gneiss (Xg) and is overlain conformably by the trachydacite (Thd) unit. The basal trachyandesites are glassier, irregularly jointed, darker, and have significantly fewer and smaller phenocryts than all other volcanic units. The total north-to-south map distance of this unit is approximately $2 \mathrm{~km}$; it maintains a general thickness of $60 \mathrm{~m}$ over much of its north-to-south exposure but tapers appreciably to 6-10 meters at its northern and southern limits before being cut off by normal faults.

\section{Trachydacite Lava Flows and Domes (Thd)}

The trachydacite unit (Thd) has a maximum thickness of $170 \mathrm{~m}$ and lies nonconformably on Early Proterozoic orthogneiss (Xg) and conformably over the basal trachyandesite (Thbb). Conformably overlying the trachydacite is basaltic trachyandesite flows (Thb). Gray, buff, white, and tan, and pink blocky domes, flows, and breccias are found on the west flank of the main central ridge and across the prominent northern ridge 
(Fig. 2). The northernmost exposures of the trachydacite flows and breccias, found in the middle of the northern ridge, display similar dome-like features to those found on the western flank to the southwest, but a 3-5 m thick distinctive purple trachyandesite lava is found in the middle of the unit (3951000 m N, $675500 \mathrm{~m} \mathrm{E}$ ). Dominant phenocrysts are plagioclase, hornblende, and biotite comprising 35-40 volume percent of the rock locally with 20-25\% plagioclase, 5-8\% hornblende, and 5-8\% biotite. Plagioclase microlites make up the majority of the matrix accompanied by hematite. In contrast to the overlying trachyandesite flows (Thb), vesicles are rare. The majority of the unit is conspicuously brecciated with hematite staining, accentuating the blocky nature of domes and with lesser degrees of staining throughout flows and breccias. At the base of the unit on the west side of the map area, a few unbrecciated gray to white rounded fins are nearly absent of hematite staining (Fig. 7).

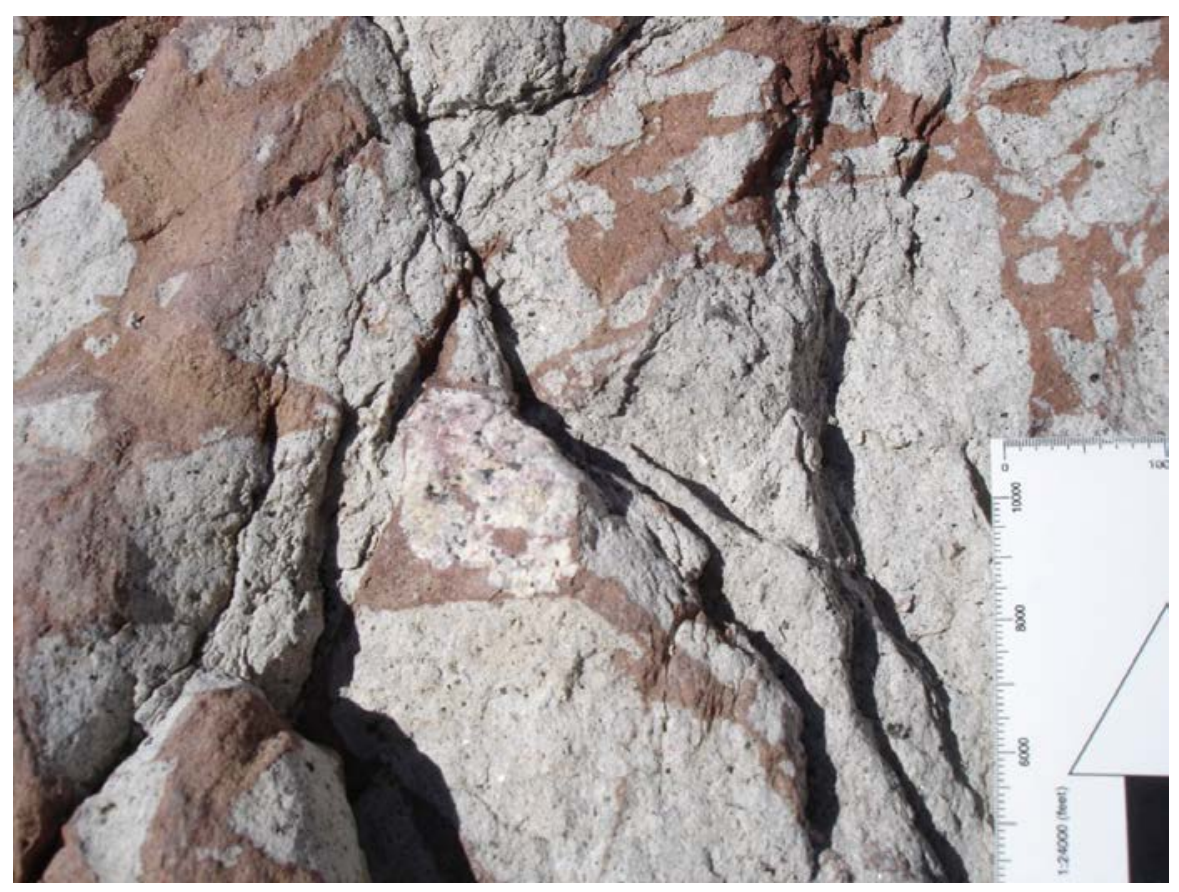

Figure 7. Outcrop of hematite-stained trachydacite (Thd). Note felsic clast in center. 
Outcrops of Thd showing the most obvious dome-like morphology are exposed in the central portion (394545m N, 676317m E; 3945125m N, 675806m E; and 3944898m N, 675714m E: asterisks on Plate 1 and Fig. 8) and in the lower half of the unit. The trachydacite unit thins moderately to the north and south and presumably continues to thin but is obscured by normal faults.

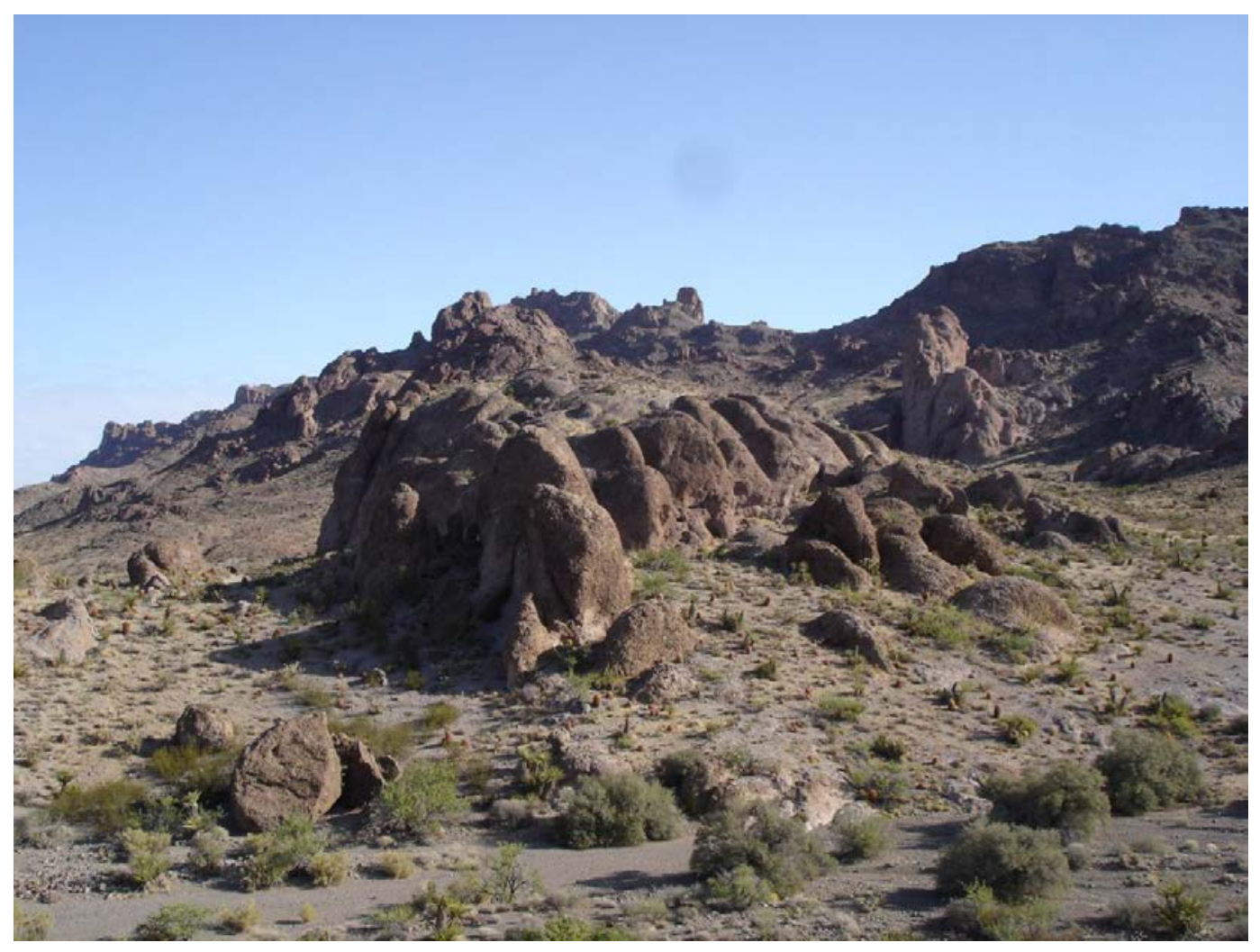

Figure 8. Trachydacite breccia domes (Thd) along the western flank of the northern Highland Range.

Near the top of the unit, purple and dark gray trachyandesite flows from 2 to $3 \mathrm{~m}$ thick are intercalated with the dacite. The uppermost 3 to 5 m occasionally displays conspicuous light-colored (tan to white) lava flows with 1 to $1.5 \mathrm{~cm}$ hornblende phenocrysts (3944460m N, 676880m E and 3951100m N, 677100m E). Flows and autobreccias have irregular steep to sub-horizontal dips. Porphyritic felsic phaneritic 
xenoliths are present, but rare (Fig. 7). Localized pockets of lithic tuff (Tvb) fill

paleotopography as buttress unconformities and are overlain by trachyandesite (Thb) lava flows (Fig. 9).

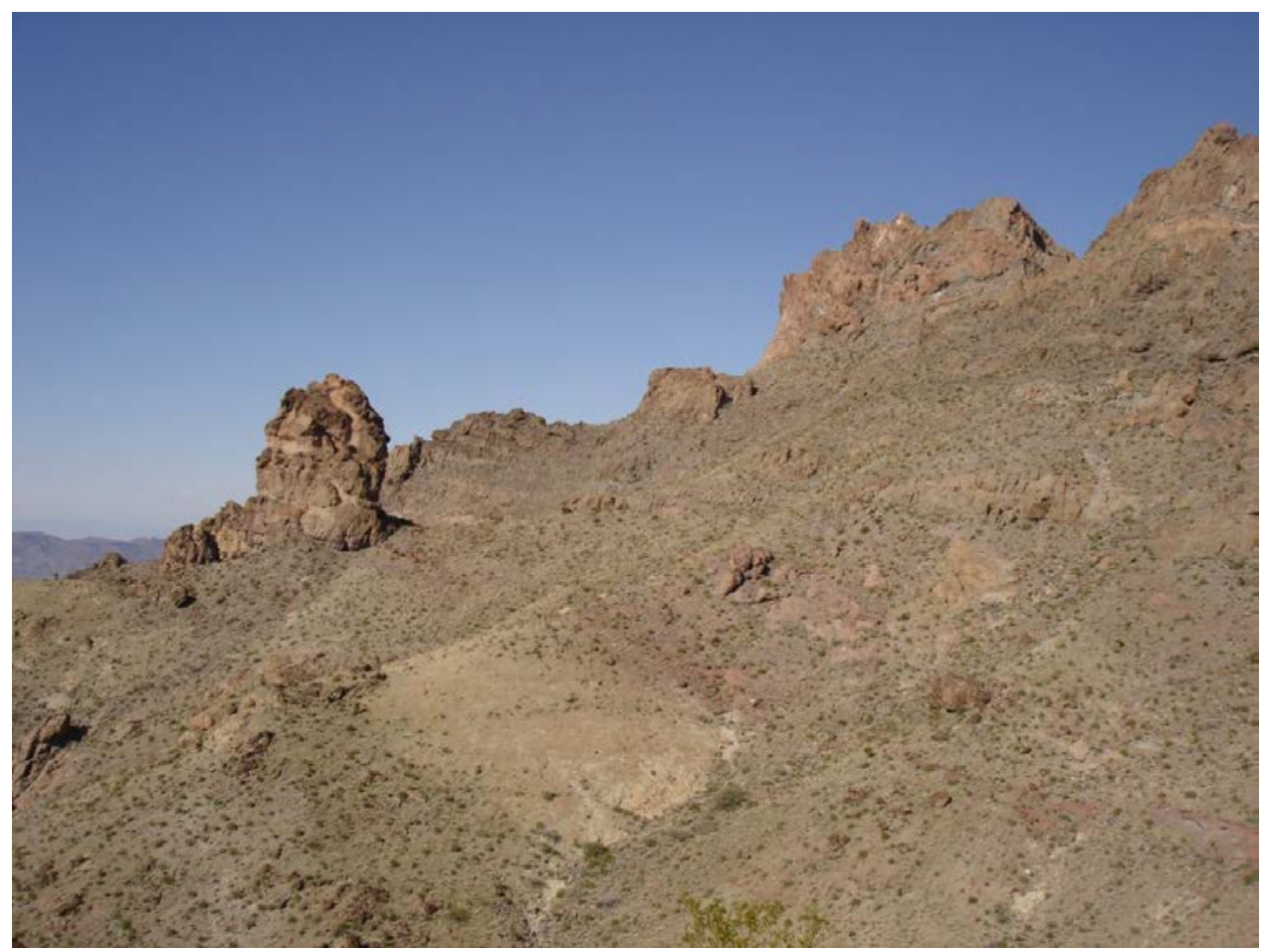

Figure 9. View of the western flank of the main central ridge (Fig 1). Teardrop shape of crumbly, buff-colored, slope-forming volcanic breccia (Tvb) buttressed against and covered by orange and reddish brown trachydacite (Thd) and trachyandesite flows (Thb).

\section{Volcanics of the Highland Range: Trachyandesite Flows and Volcanic Breccia (Thb)}

Trachyandesite flows and volcanic breccia lie conformably over the trachydacite unit and is capped by the Tuff of Mount Davis and Tuff of Bridge Spring (Tdt/Tb). Thb is a series of trachyandesite and basaltic trachyandesite flows and autobreccias in colors that include gray, purple-gray, brown, orange, dark gray, and black. The calculated aggregate thickness of this map unit is approximately 3,000 m, but it is important to note that this includes the intercalated Tvb, which has varying thickness within Thb. 
Two prominent 10-12 m thick, very continuous, cliff-forming lava flows are found near the highest elevation along the Main Central Ridge (Fig. 2), but are atypical (Fig. 10). Instead, most lava flows of Thb are dismembered into semi-continuous lenses where meter-thick autobreccia zones occur between more massive lava along the same depositional horizon (Fig. 11). Individual flows are differentiated by thick, lightercolored autobreccias surrounding the darker, more uniform, and crystalline core. Lava flows are commonly found at differing orientations to neighboring flows. The $200-300 \mathrm{~m}$ of Thb exposed on this cliff face displays this bedding character prominently, where lavas with 1 to $4 \mathrm{~m}$ autobreccia shells, are intercalated with localized debris flows/lahars, accretionary lapilli horizons, and epiclastic sandstone lenses, some of which can be traced into sandstone (clastic) dikes within flows.

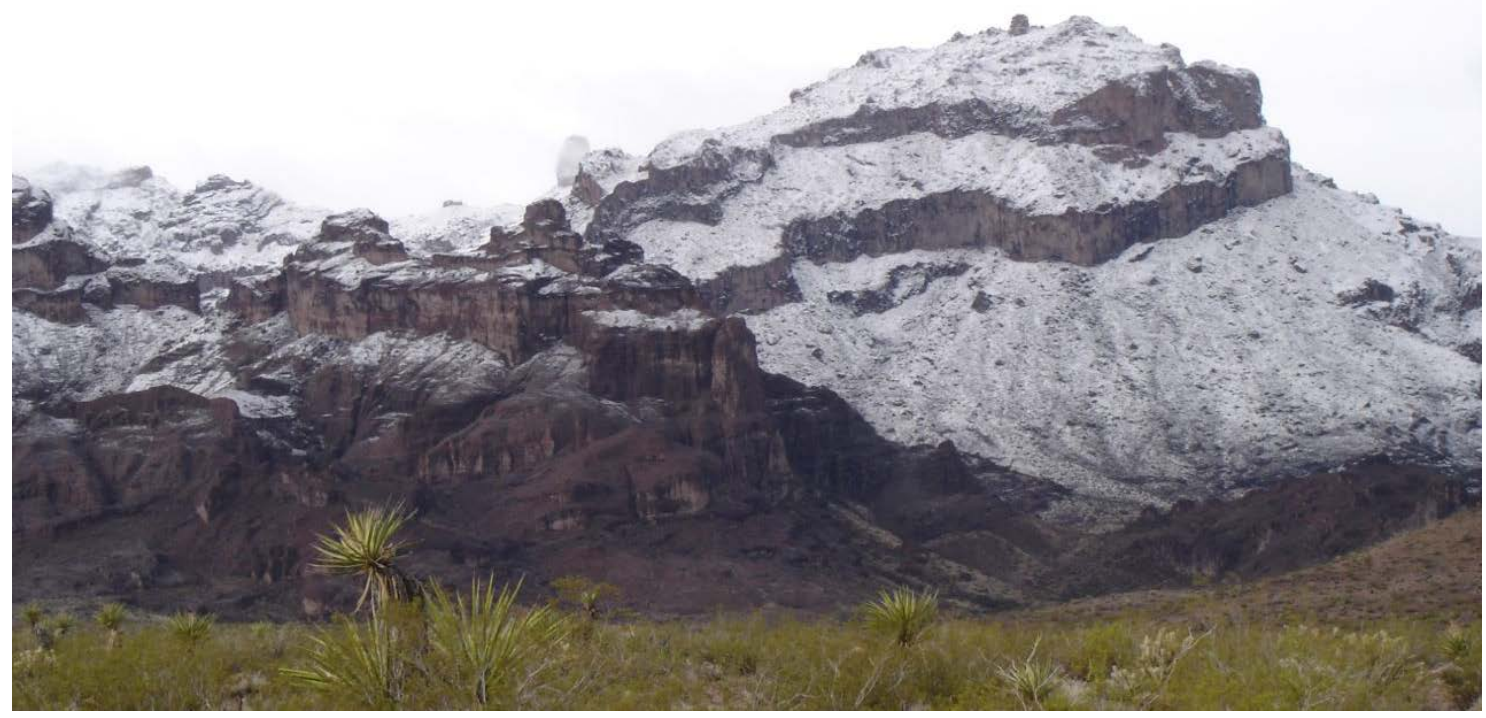

Figure 10. View of eastern flank of the Main Central Ridge. The regional moniker for this prominent peak is "The Castle" or "Third Molar Peak." A dusting of snow and hail accents two prominent trachyandesite lava flows (Thb). 


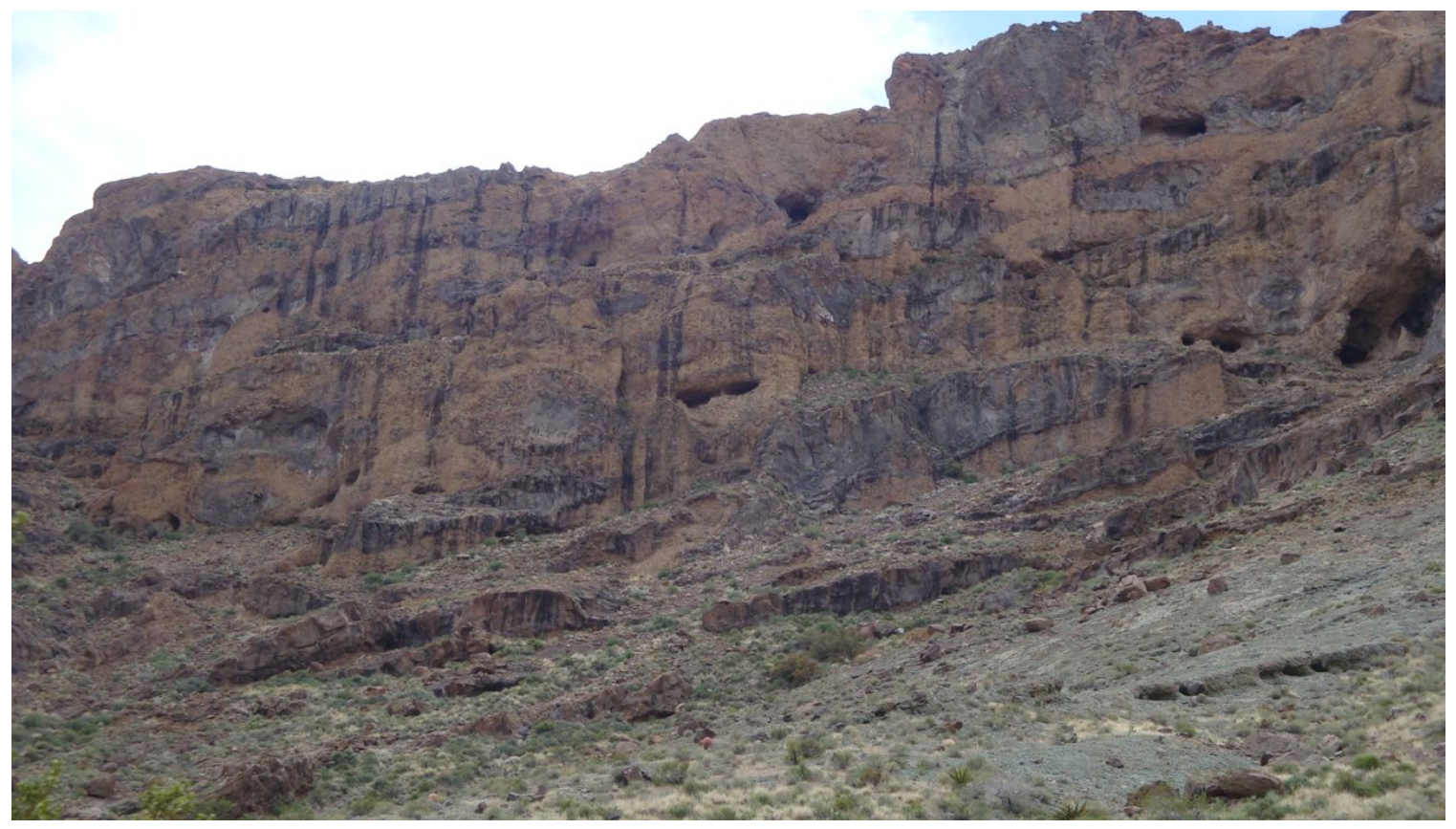

Figure 11. Cliff face exposure of lava and autobreccia. Irregular lenses of individual trachyandesite lava flows (Thb) encapsulated by orange autobreccia. Cliff face is approximately $70 \mathrm{~m}$ tall. Green volcanic breccia of Tvb forms the slope in the foreground.

The upper $500 \mathrm{~m}$ of the unit express the most variation. Autobreccia and lava clasts within the debris flows are black and gray, have fewer and smaller phenocrysts, and are richer in vesicles (5-20\%), compared to the more massive lava flow outcrops in the unit. Debris flows are found in greater abundance stratigraphically higher. Intercalated lava flow colors vary from maroon to brown and gray.

Clinopyroxene, 1-4 mm in length, is the primary phenocryst mineral, followed by 1-2 mm plagioclase phenocrysts that are prominent in weathered outcrops (Fig. 12). Orthopyroxene is sparse and usually small ( $<1$ to $1 \mathrm{~mm}$ ), but one flow contains large (4 mm) orthopyroxene crystals and clinopyroxene phenocrysts. Amphibole and biotite are small (1 to $2 \mathrm{~mm}$ ) and occur as either minor phases or are absent with titanomagnetite as a minor phenocryst mineral. 


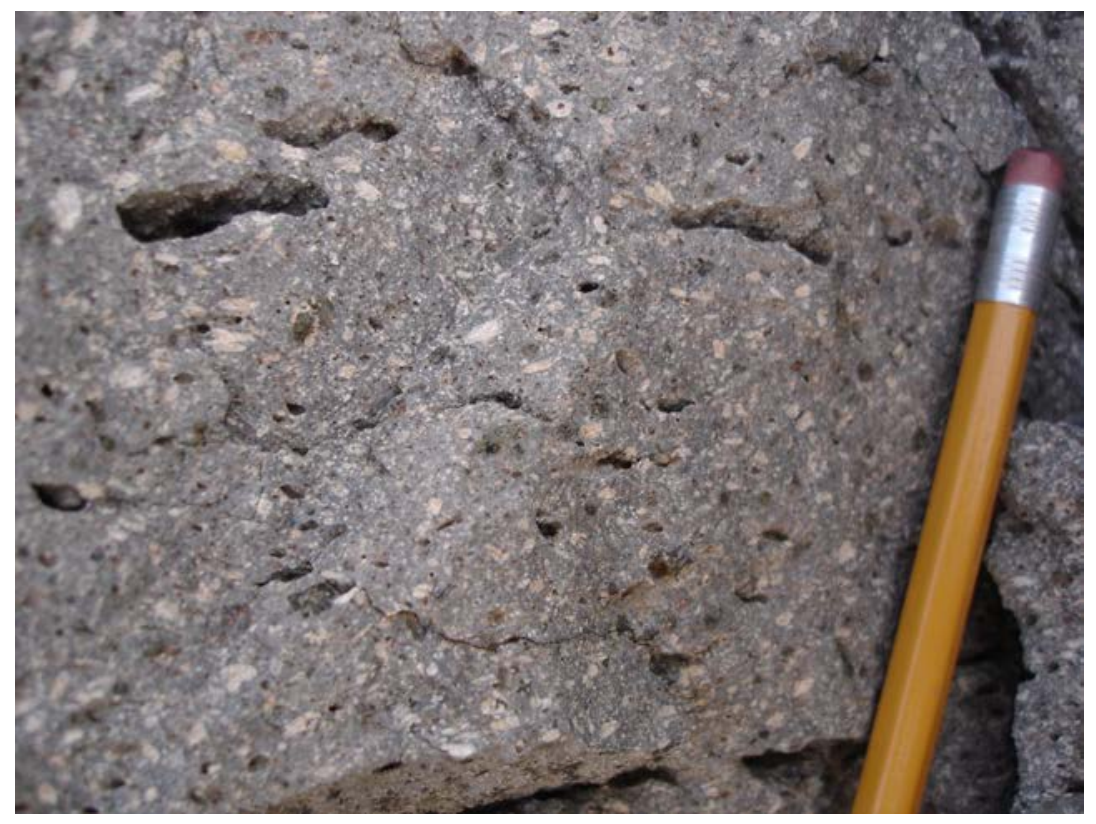

Figure 12. Outcrop exposure of trachyandesite (Thb). White- to pink-colored plagioclase and dark green and red pyroxenes are common diagnostic minerals.

Phenocryst mineralogy is consistent throughout the series of flows, but modal abundance varies appreciably (See Petrology section). Vesicles are found randomly, showing flattening closer to the edges or flows but not always representing horizontal, as most flows are non-continuous.

\section{Volcanic Breccia: Lithic Tuff and Debris flows (Tvb)}

Unit Tvb comprises a diverse group of tuffaceous rocks that are intercalated with Thd and Thb. Included within Tvb are: 1) green-yellow- to tan-colored, massive lithic tuff (non-welded); 2) tan to light gray, massive-bedded, matrix-supported debris flows; 3) white, tan, and red, thin-bedded, tuffaceous sandstones. Tvb extends from the central Highland Range to the northern edge of the map area, and is also found in the low western hills of the map area where it has been dropped down by normal faulting. Unit thickness varies from $0 \mathrm{~m}$ in the central Highland Range (just south of the map area) to 
approximately $670 \mathrm{~m}$ around latitude $3949000 \mathrm{~m} \mathrm{~N}$ in the central area of the Northern Ridge (Fig. 2). In the southern part of the map area, it is possible to distinguish a yellow, 20 to 30 m-thick lithic tuff from a stratigraphically higher, green lithic tuff of similar thickness. These two lithic tuffs are separated by up to approximately $100 \mathrm{~m}$ of Thb lava flows (Fig. 13). They were distinguished as "lower lithic tuff” (Tltl) and "upper lithic tuff” (Tltu) by Davis (1984), whose map area overlapped the present map area in the south.

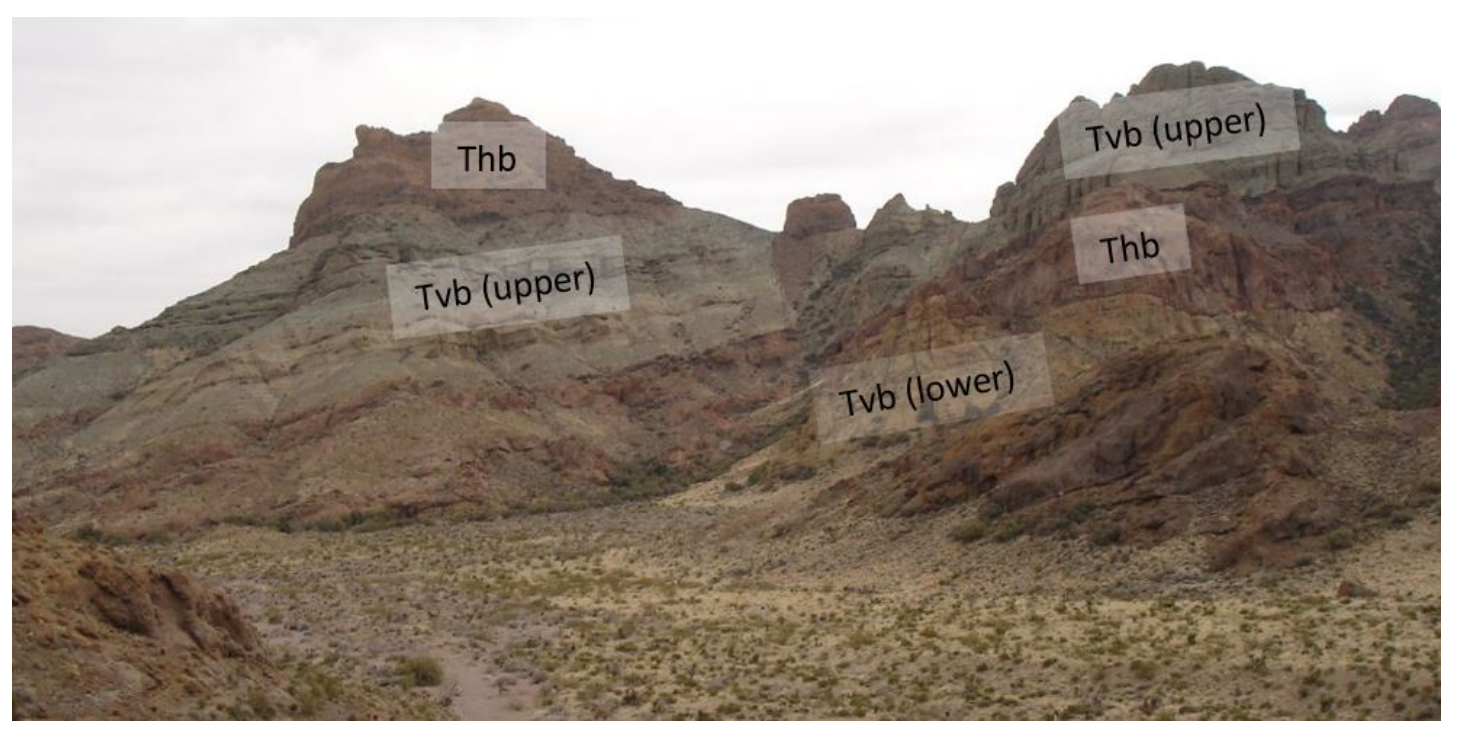

Figure 13. East-tilted sequences of lava and volcanic breccia. Yellow, green, and tan volcanic breccias (Tvb) intercalate with red-orange trachyandesite lava flows (Thb).

However, at roughly 3946500m N latitude, the intervening Thb lava flows thin appreciably and occur instead as discontinuous lenses interfingered within the continuous sequences of Davis’ upper and lower lithic tuff (Fig. 14). Other than the color contrast noted above, there is no obvious distinction between the two, and so they are here considered part of the same map unit (Tvb). Importantly, though, the presence of two 
distinct tuffs separated by lava flows in the southern part of the map area clearly shows that multiple pyroclastic units occur in Tvb, along with the numerous epiclastic rocks.

The yellow, green, and tan conspicuous volcanic breccia forms steep slopes and cliffs where overlain by the predominantly darker, more resistant lavas. Numerous canyons and cliffs are best developed on the east flank of the map area at the latitude 3944000m N (UTM 11 S) (Fig. 13). Outcrops and ridges lacking capping flows have gentle to steep slopes that erode to a crumbly and pocked surface as lithic fragments weather and pop out (Fig. 15).

Brown, orange, and gray andesite and dacite clasts dominate the lithic fragments with subordinate tuffaceous clasts and partially banded dacite and rhyolite. Clast size counts were not done in this unit, but clast size ranges from pebbles to boulders up to $3 \mathrm{~m}$

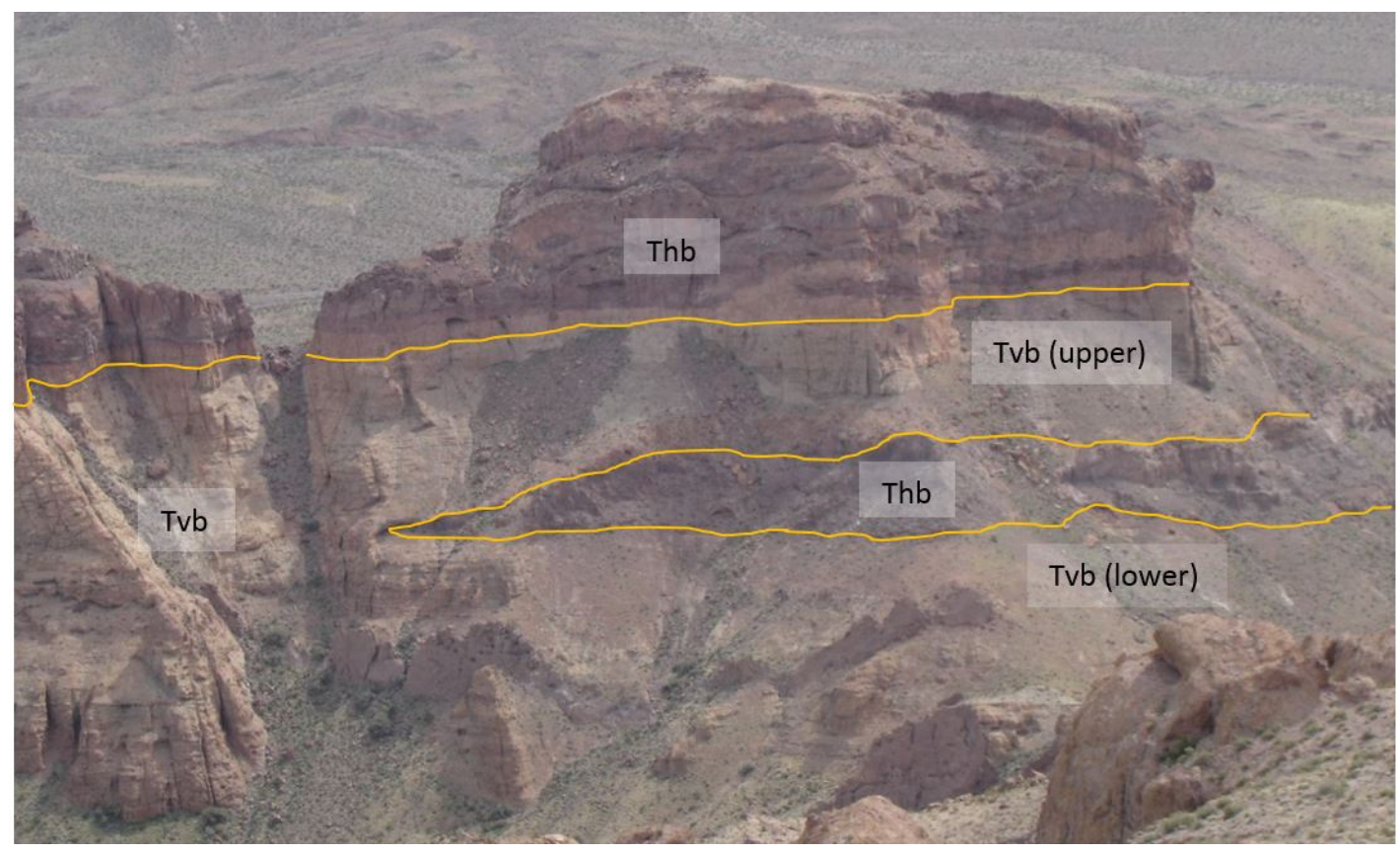

Figure 14. Tapering lava flow within volcanic breccia. View to the east. Trachyandesite (Thb) flow tapering to the north within a thick section of volcanic breccia (Tvb). Trachyandesite flows (Thb) also cap the ridge. Contacts are orange lines. 


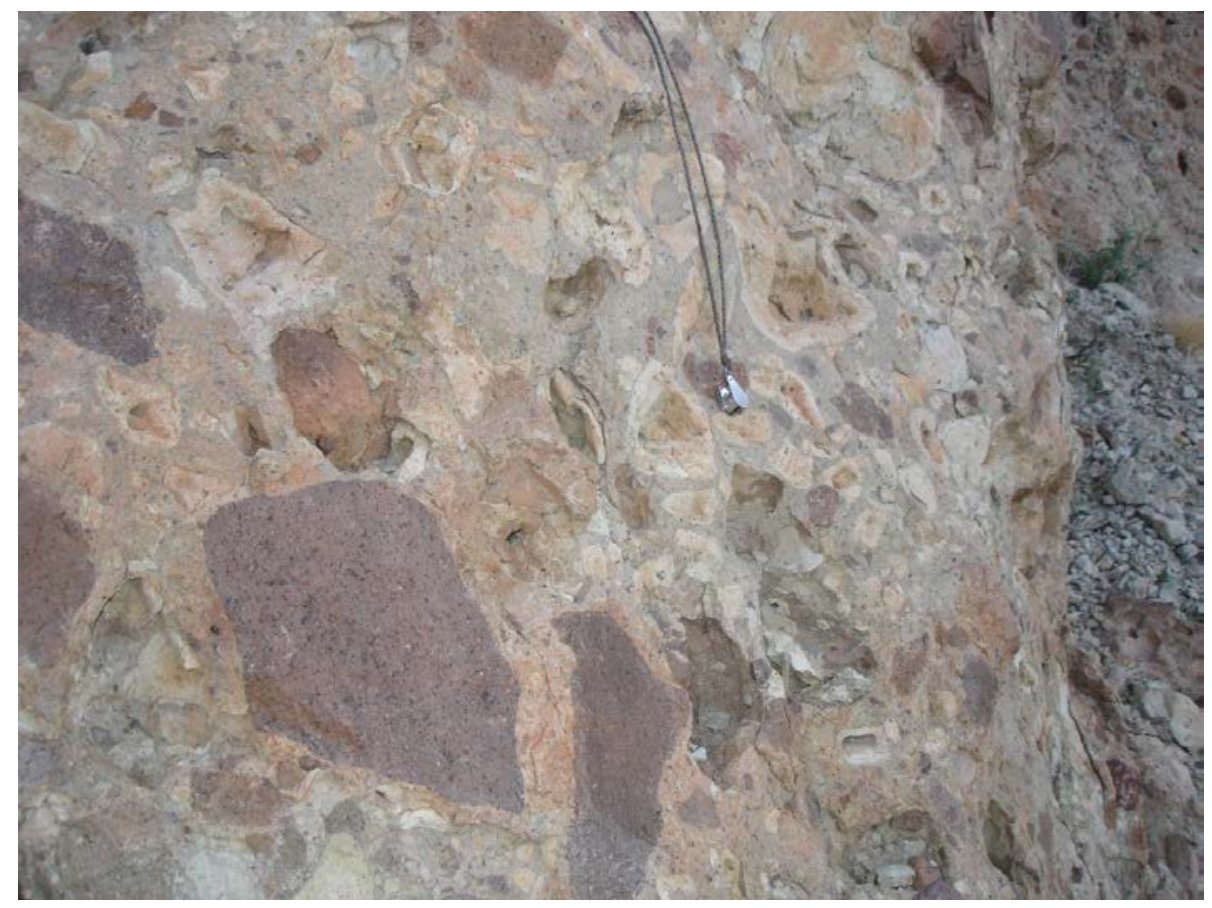

Figure 15. Outcrop of typical volcanic breccia (Tvb). Hand lens for scale.

with a preponderance of 10 to $15 \mathrm{~cm}$ clasts. From 50+ meter distances, lithic fragments appear to show moderate bedding, but bedding features are weak to absent at close examination (meters to a few meters). The majority of the matrix lacks glass and contains 1 to $2 \mathrm{~mm}$ plagioclase and pyroxene crystals, similar to what is observed in the clasts. The best expressions of depositional surfaces are represented as thin $(<30 \mathrm{~cm})$ lenses of laminated sandstone (Fig. 16) found sporadically throughout the unit. A $40 \mathrm{~cm}$ block of andesite appears to have punctured and deformed a well-sorted (tuffaceous?) fine-sandy lens, indicating it is a ballistically transported volcanic bomb landing in an unlithified or very weakly lithified sediment (Fig. 17). 


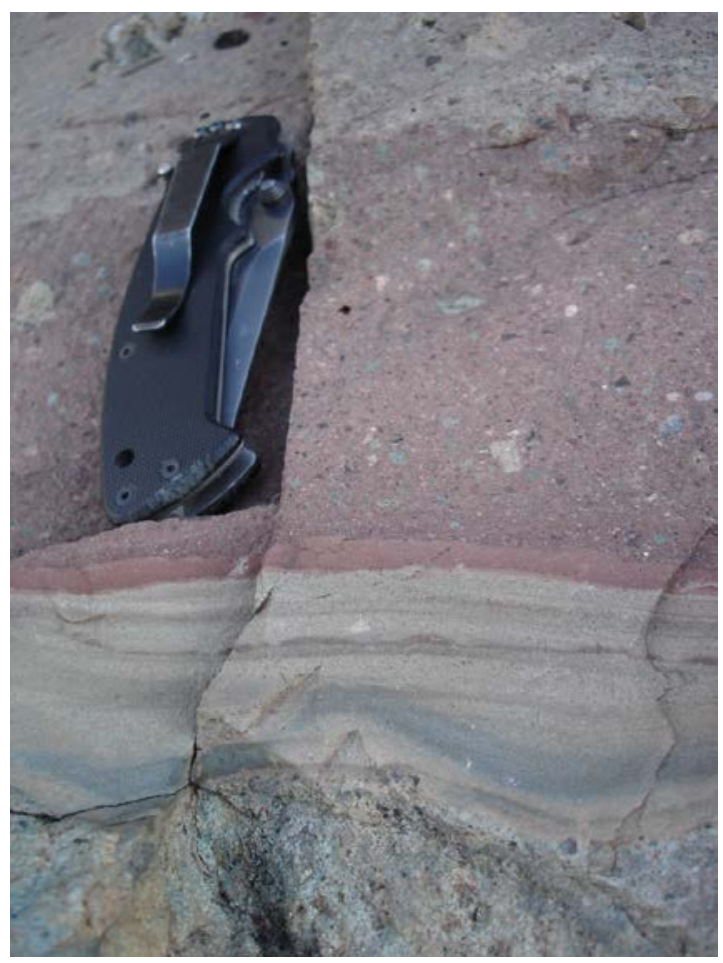

Figure 16. Detail of laminations in volcanic breccia. Thin lens of fine-grained sandstone within alternating hematite rich (above) and poor (below) lenses of the volcanic breccia. Note green propylitic alteration near the bottom of the sandstone lens and lower volcanic breccia. Knife is approximately $10 \mathrm{~cm}$ long.

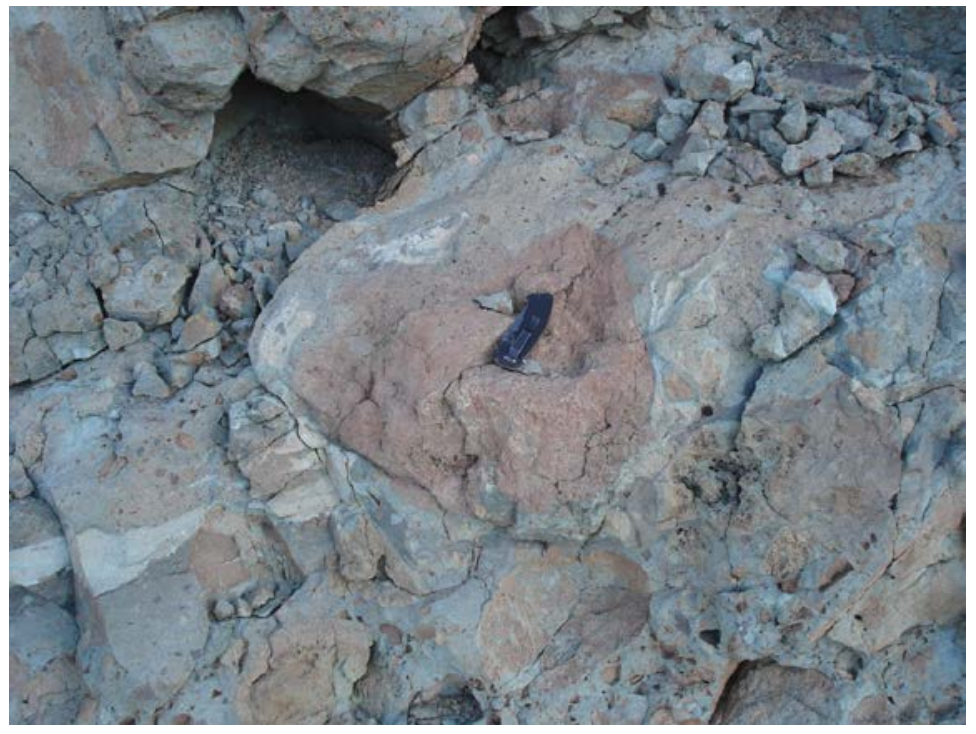

Figure 17. Volcanic bomb within volcanic breccia. Trachyandesite bomb displaces thin lens of fine-grained sandstone within Tvb unit. Knife is approximately $10 \mathrm{~cm}$ long.

The volcanic breccia contains small ( $<1$ to $2 \mathrm{~mm}$ ) phenocrysts of plagioclase (20\%), clinopyroxene (10\%), biotite (8\%) and sparse amphibole $(<3 \%)$, which are set in a 
plagioclase microlite-rich matrix. Higher in the stratigraphy, trachyandesite and trachydacite clasts increase in size and number, making up approximately 30 to $40 \%$ of the rock for the majority of the unit. At the lowest stratigraphic exposure, intermediate volcanic lithic clasts in Tvb do not typically exceed $1 \mathrm{~cm}$, but increase in size from lapilli to large blocks within $30 \mathrm{~m}$ higher up in the unit. Rare 3 to $6 \mathrm{~cm}$ granitoid and dioritic clasts are also present in Tvb.

\section{Trachyandesite and Trachydacite Dikes (Thbi)}

Many north-south- and northeast-southwest-striking dikes invade the eastern and northern parts of the northern Highland Range. Dikes are purple, gray, and maroon, ranging from 2 to $5 \mathrm{~m}$ in thickness, and dip moderately to steeply (50 ${ }^{\circ}$ to $85^{\circ}$ ) (Fig. 18 ).

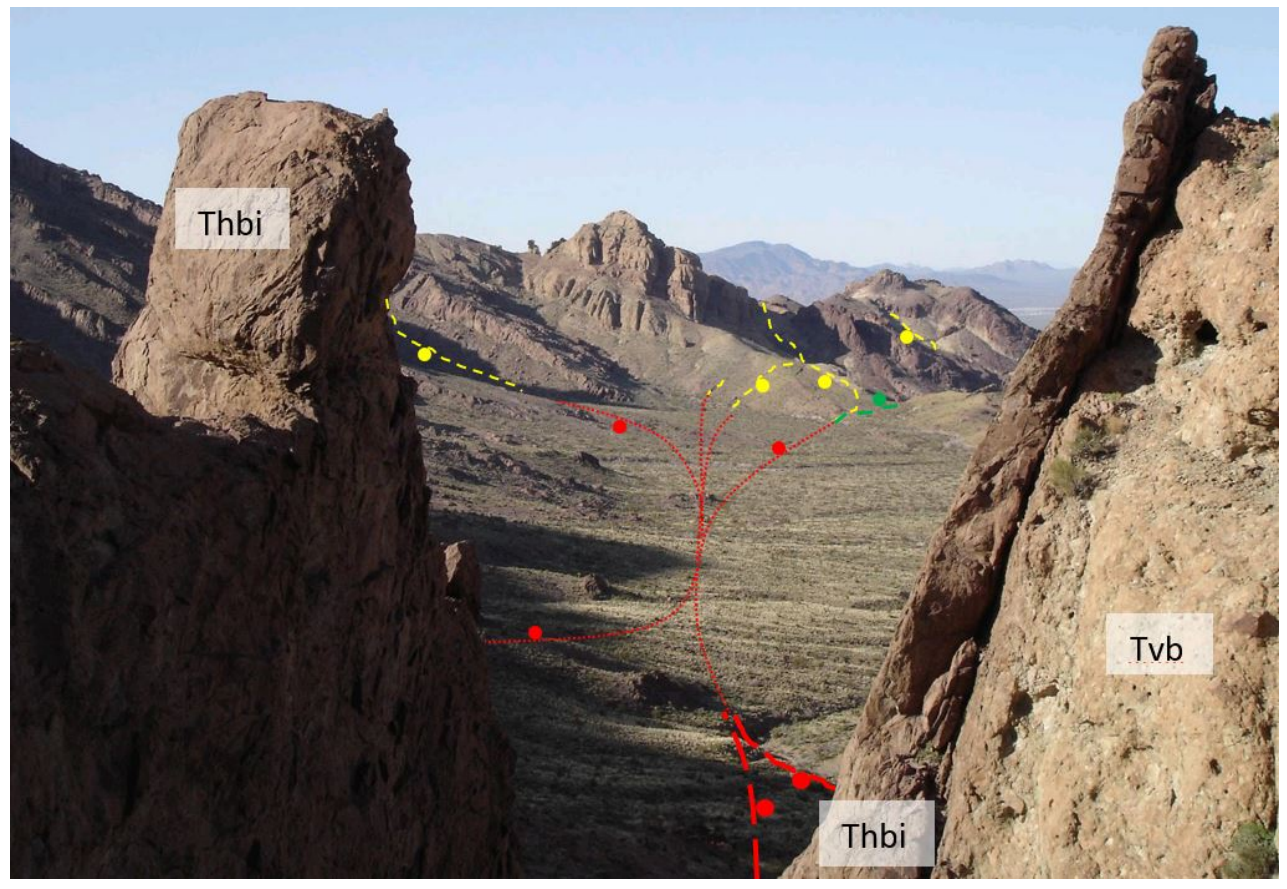

Figure 18. North-striking dike and faults. A 3 to $4 \mathrm{~m}$ thick west-dipping Trachyte dike (Thbi, 179/54) intrudes tan volcanic breccia (Tvb), all spilt by a subparallel east-dipping fault (330/75), ball is on downthrown side. The east-dipping fault is a minor spur of more prevalent west-dipping faults. View is on the fault looking along strike (330). 
A phenocryst assemblage of pyroxene (3 to 15\%), plagioclase (2 to 18\%), amphibole (3 to $5 \%$ ), and occasional biotite (1 to $2 \%$ ) is comparable to average values of trachyandesites (Thb and Tvb), but with somewhat less plagioclase and more amphibole (Fig. 19) (Appendix B: Table A). Dikes are generally more resistant than the surrounding rock, but occasionally thin or disappear into fault surfaces that define many valleys and drainages.

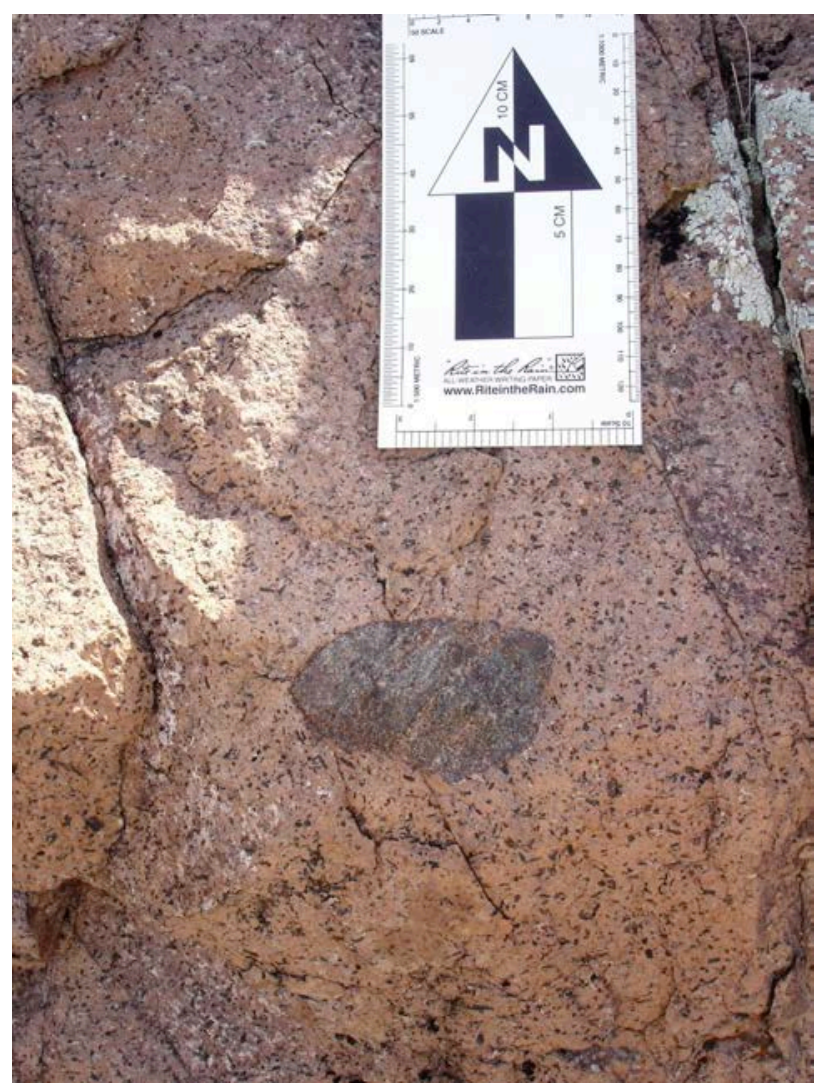

Figure 19. Outcrop view of dike (Thbi). Mafic gneiss xenolith surrounded by andesite with abundant pyroxene, plagioclase, and amphibole phenocrysts.

\section{Tuff of Bridge Spring and Tuff of Mount Davis (Tb/Tdt)}

The Tuff of Bridge Spring (15.20 Ma) and Tuff of Mt. Davis (15.00 Ma) sit conformably on intermediate flows and breccias of the northern Highland Range 
(Thb)(Fig. 4). Both units described by Faulds et al. (2001) (Plate 1) in the central and southern Highland Range continue to the north and dip moderately $\left(18^{\circ}\right.$ to $\left.38^{\circ}\right)$ to the east, along the eastern edge of the range (Fig. 2). Outcrops are highly resistant and form rounded cliffs of tan and peach-orange, crystal-rich, welded tuff locally ranging from 10 to 50 meters thick. Basal contacts are undulatory as they fill the paleo-topography made by the underlying lavas and breccias. Outcrop and hand samples reveal the tuffs contains chiefly sanidine, plagioclase, and biotite.

The Tuff of Bridge Spring was first described by Anderson (1971) and was later discovered in the stratigraphy of much of the northern Eldorado Mountains and immediately surrounding ranges (Anderson, 1971; Morikawa, 1994; Gans et al., 1994; Price and Faulds, 1999). The Tuff of Mount Davis is less well known and was first described by Faulds et al. (1995) in the Lake Mojave area. The Tuff of Mt. Davis and Tuff of Bridge Spring serve as an important regional marker units that cap the volcanic rocks of the Highland Range, and whose ages are well established (Faulds et al., 2001). Both tuffs are similar, but differ distinctly in crystal abundance and crystal size and have slightly different ages, as noted above. A megabreccia and/or conglomerate locally separates the two tuffs in the central Highland Range. The Tuff of Mount Davis has $10-20 \%$ more phenocrysts in welded parts, is nearly devoid of sphene, and is slightly darker than the Tuff of Bridge Spring (Faulds et al., 2002a; 2002b). No exposures of the separating conglomerate were observed in the northern Highland Range. Most outcrops in the map area are more likely tuff of Mount Davis based on crystal abundance and color as defined by Faulds et al., (2001; 2002a; 2002b). A few locations, at the base of 
outcrops, contain lower abundances of phenocrysts. These outcrops may be the Tuff of Bridge Spring. Without extensive thin section work or paleomagnetic data, it is difficult to determine conclusively if both tuffs are present in the map area. Therefore, the two units are mapped as one in the northern Highland Range.

\section{Neogene (Tertiary) Conglomerate (Tc)}

Sitting disconformably above the Tuff of Bridge Spring and the Tuff of Mount Davis is a tan, matrix- and clast-supported conglomerate of unknown thickness. Faulds et al. (2002a) observed it to be more than $400 \mathrm{~m}$ thick in the central Highland Range. Exposures found in the central Highland Range on the west side presumably continue north but are covered by Quaternary fan deposits from the McCullough Range. Neogene (formerly described as Tertiary) conglomerate is exposed on the eastern reaches of the northern Highland Range and is also overlain unconformably by Quaternary alluvium.

Conglomerate in the northern Highland Range is composed of cobbles, gravels, and boulders (most clasts ranging from 5 to $30 \mathrm{~cm}$ ) of trachyandesite, trachydacite, gneiss, Tuff of Bridge Spring, Tuff of Mount Davis, and other banded rhyolitic to dacitic clasts, and vesicular basalts of unknown origin. Boulders (0.5 to $2 \mathrm{~m}$ ) of Tuff of Bridge Spring and Tuff of Mount Davis are common and conspicuous. Clasts are generally equidimensional and subrounded to rounded. Bedding is poor and best expressed by horizons of carbonate accumulation on loosely imbricated gravels and cobbles within packets of moderately sorted conglomerate lenses. Many boulders and cobbles exposed at the surface have a dark brown to black desert varnish. 


\section{Quaternary Alluvium, Fan, and Debris Flow Deposits (Qal)}

Alluvium fills the broad valley floors, washes and drainages surrounding the northern Highland Range. Gravels, cobbles, and sands of mostly lithic tuff and trachyandesite fill ephemeral stream channels. Large cobbles and boulders are predominantly trachyandesite and gneiss that are similar to outcrop exposures upslope. Debris flows and colluvial accumulations are present below the steepest slopes and locally clog narrow drainages. Various ages of fan deposits are recognized by the degree of desert varnish and pavement, the amount of carbonate accumulation in soil horizons, and amount of incision. Fan deposits are slightly lithified to unconsolidated. Beds are common and extensive and can be traced for tens of meters in length; lenses of clast-supported gravels and cobbles with occasional boulder lag deposits

are common. Caliche and carbonate accretions highlight bedding features, root channels, and krotovina.

\section{PETROLOGY}

\section{Petrography/Thin Sections}

Thirty-six thin sections of representative field samples of the trachytic rock units (Thbb, Thd, Tvb, Thb, and Thbi) were examined to better characterize the volcanic and volcaniclastic rock units and to determine modal mineral abundances (Appendix A: Photomicrographs). Table A displays the mineral modes abundance (Appendix B: Tables).

Plagioclase ranges from 16 to 23 modal percent, clinopyroxene from 5 to 7 modal percent, and orthopyroxene from 2 to 3 modal percent. Plagioclase laths constitute the 
matrix. Minor amounts of biotite and amphibole (hornblende) are common. Trace quantities of hematite and iron-titanium oxides are observed in many samples.

The most common type of alteration is replacement of plagioclase by small amounts $(<1 \%)$ of sericite within the matrix. Amphibole and biotite, where present (mostly in the dikes and Thd), show pitting and replacement by opaque minerals along cores and rims (Fig. 20). Dikes are similar in matrix color to the majority of the cores of lava flows. Modal mineral assemblages in dikes (Thbi) and trachyandesite lavas (Thb) are similar, with dikes having lesser amounts of plagioclase and a greater abundance of amphibole. Unequivocal pumice lumps are relatively uncommon in the lithic tuffs, and the tuffs commonly show propylitic alteration, making it difficult to obtain fresh chemical analyses.

\section{Whole Rock Analysis}

A representative set of volcanic rocks from the northern Highland Range has been analyzed for major and trace elements (Appendix B: Table B) to more clearly define rock types, facilitate comparison to other volcanic strata, and contribute to the regional geochemical catalogue. After coarse crushing at San Jose State University, using hardened steel and ceramic jaw crushers, the samples were sent to GeoAnalytical Laboratory at Washington State University for analysis. Whole rock, major, and trace elemental data were collected using automated X-ray spectrometry by a Thermo ARL Xray Fluorescence Spectrometer. Procedures are described by Hooper et al. (1993) and Johnson et al. (1999) with technical notes found at the WSU Geoanalytical website: http://environment.wsu.edu/facilities/geolab/technotes/. 


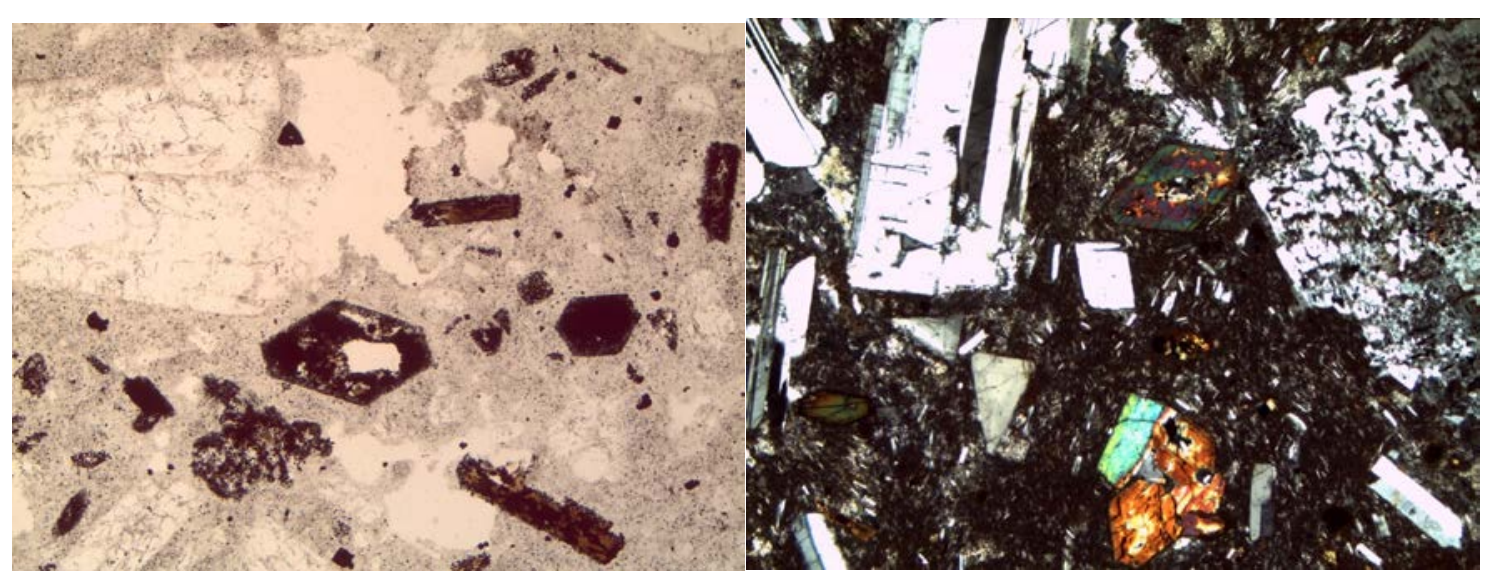

20a 14A - Thd 20b 362B - Thd

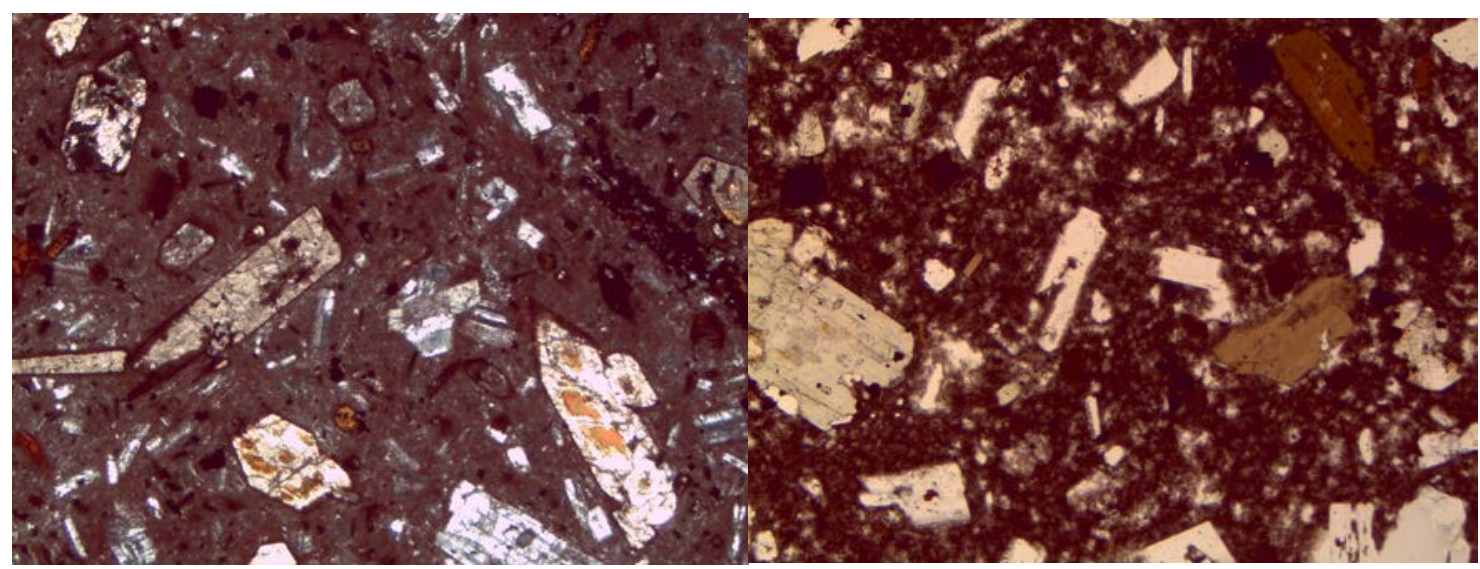

20c $\quad 56 \mathrm{~A}$ - Thd 20d 9B - Thbi

Figure 20. Pitting and replacement in thin section view. Width of field of view is approximately $3 \mathrm{~mm}$. Corresponding cross or plain polarized light view is found in Appendix A.

\section{Major Elements}

The ten representative samples collected from the map area (HR105A, HR98A, HR201A, HR78A, HR305A, HR228A, RAM9A, HR362B, RAM14A, and HR229A) are plotted on a total alkali-silica (TAS) diagram to classify the samples (Fig. 21). 

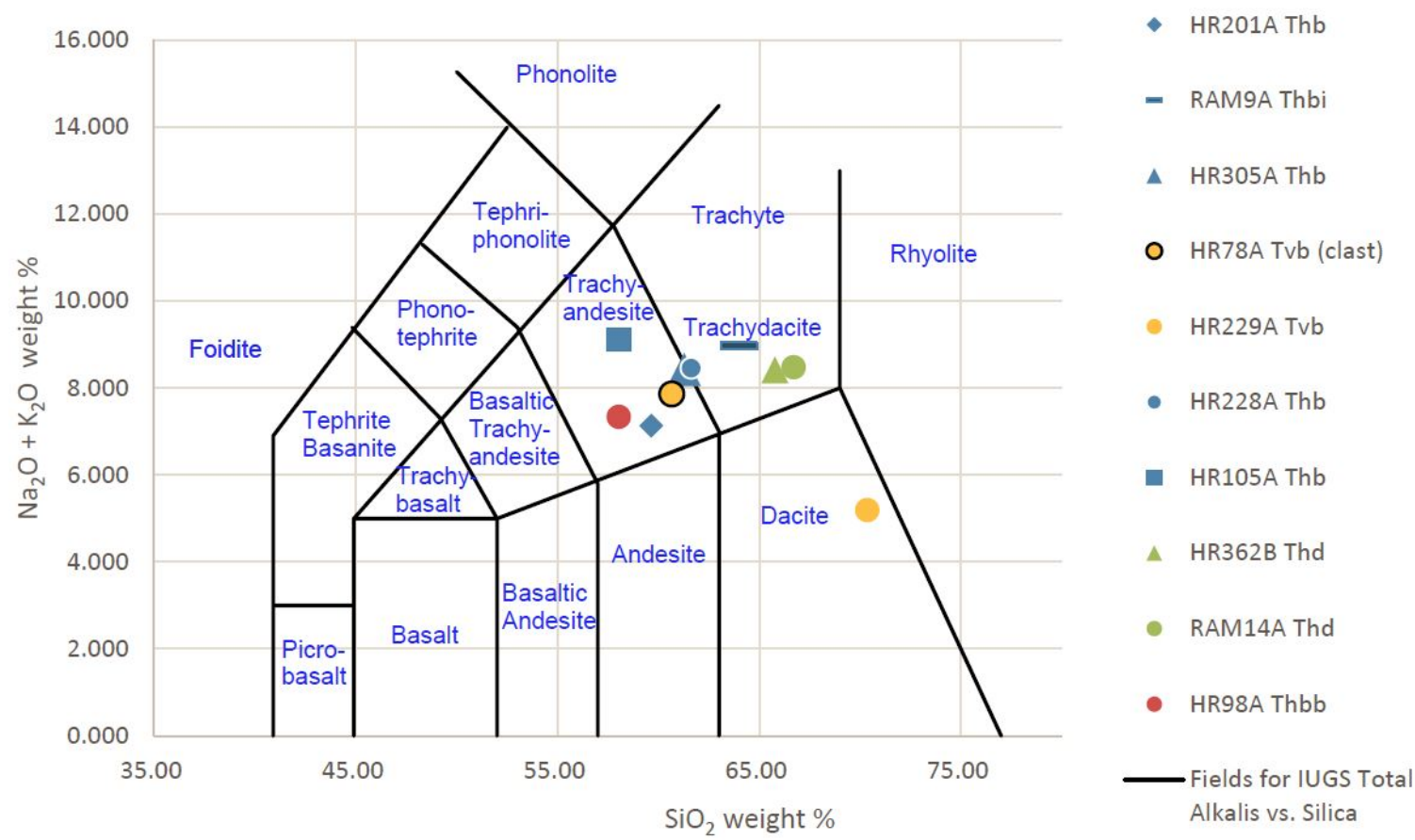

Figure 21. TAS plot of samples from the northern Highland Range. Orange circle: (Thbb), grey circle and triangle: (Thd), blue square, circle, triangle, and diamond: (Thb), yellow circles: (Tvb), blue bar (Thbi).

Samples generally fall into trachyandesite and trachydacite groups. The trachyandesite group includes samples from the Thbb, Thb and a lithic within Tvb. The trachydacite group includes the Thd, a dike (Thbi). One sample collected from the matrix of the volcanic breccia (Tvb) is an outlier and plots as a dacite. Given the widespread propylitic alteration noted earlier in Tvb, this sample may have experienced modest alkali loss, which would account for its separation from the main group of trachyandesitetrachydacite groups on the TAS diagram.

Major elements as oxides (weight \%) are plotted against concentrations of $\mathrm{SiO}_{2}$ as individual oxide Harker diagrams (Figs. 22a through 22n). Plots of $\mathrm{TiO}_{2}, \mathrm{FeO}^{*}\left(\mathrm{Fe}_{2} \mathrm{O}_{3}\right.$ and $\mathrm{FeO}$ combined), $\mathrm{MgO}, \mathrm{Zn}, \mathrm{Sc}$, Th, $\mathrm{K}_{2} \mathrm{O}, \mathrm{P}_{2} \mathrm{O}_{3}$, and $\mathrm{Rb}$ generally appear coherent with negative correlations. $\mathrm{Zn}, \mathrm{K}_{2} \mathrm{O}$, and $\mathrm{Rb}$ present two possible trends with the oldest and 
most basic sample (HR98A: Thbb) varying the furthest from the more populated trend. $\mathrm{Al}_{2} \mathrm{O}_{3}, \mathrm{Ba}, \mathrm{Na}_{2} \mathrm{O}$, and $\mathrm{Sr}$ appear to have little or no coherent trend.

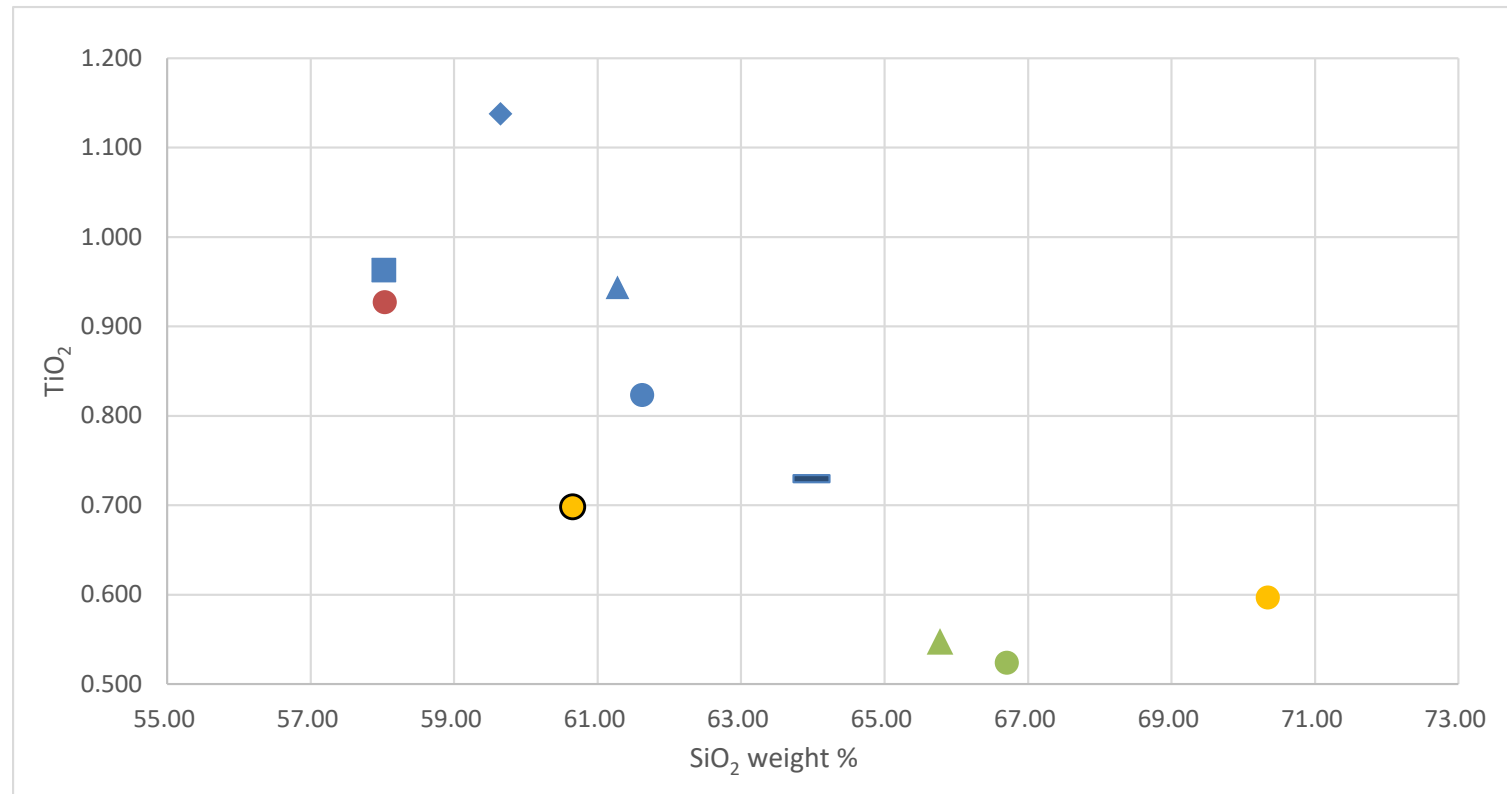

$22 \mathrm{a}-\mathrm{TiO}_{2}$

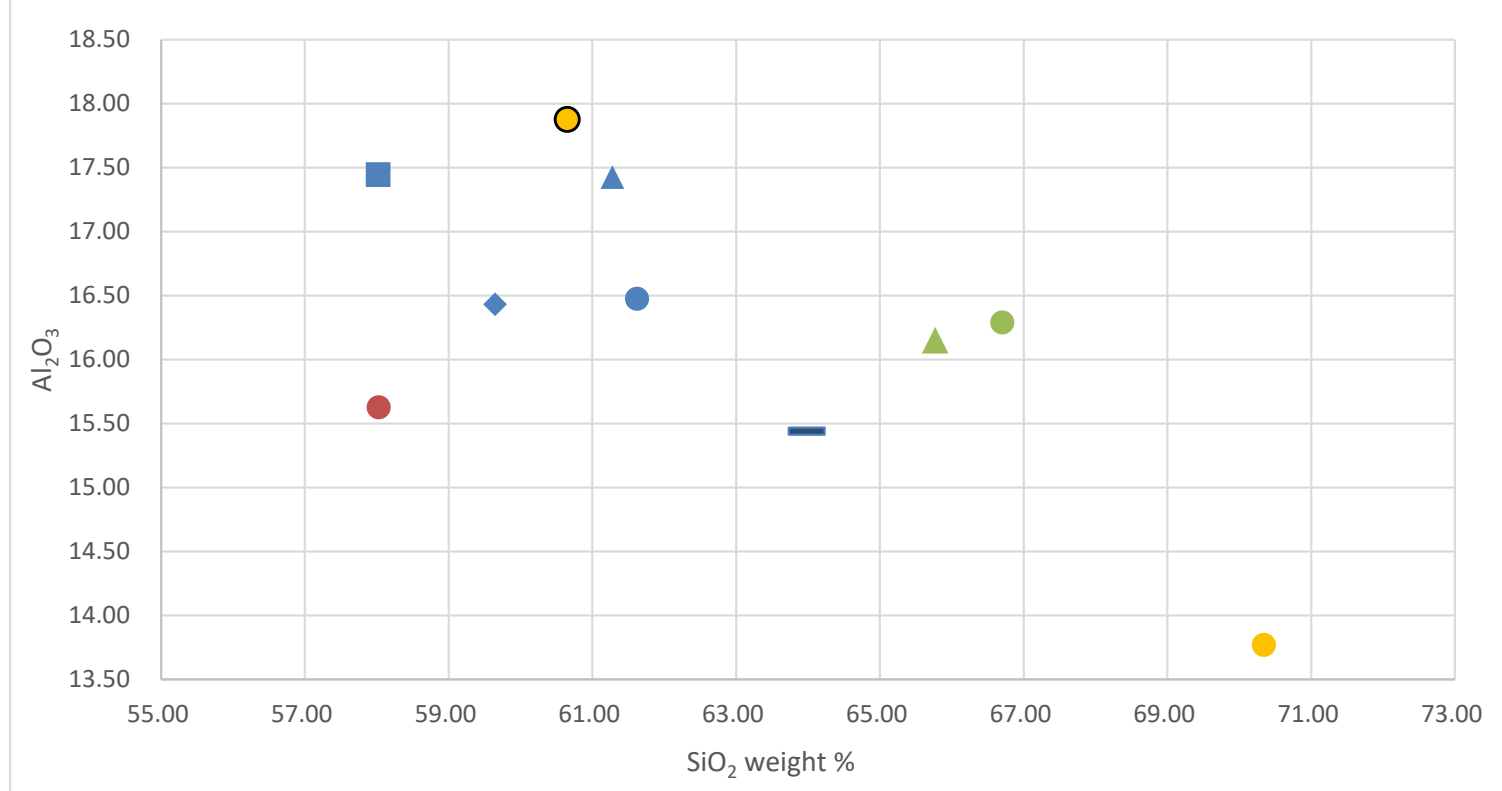

$22 \mathrm{~b}-\mathrm{Al}_{2} \mathrm{O}_{3}$ 


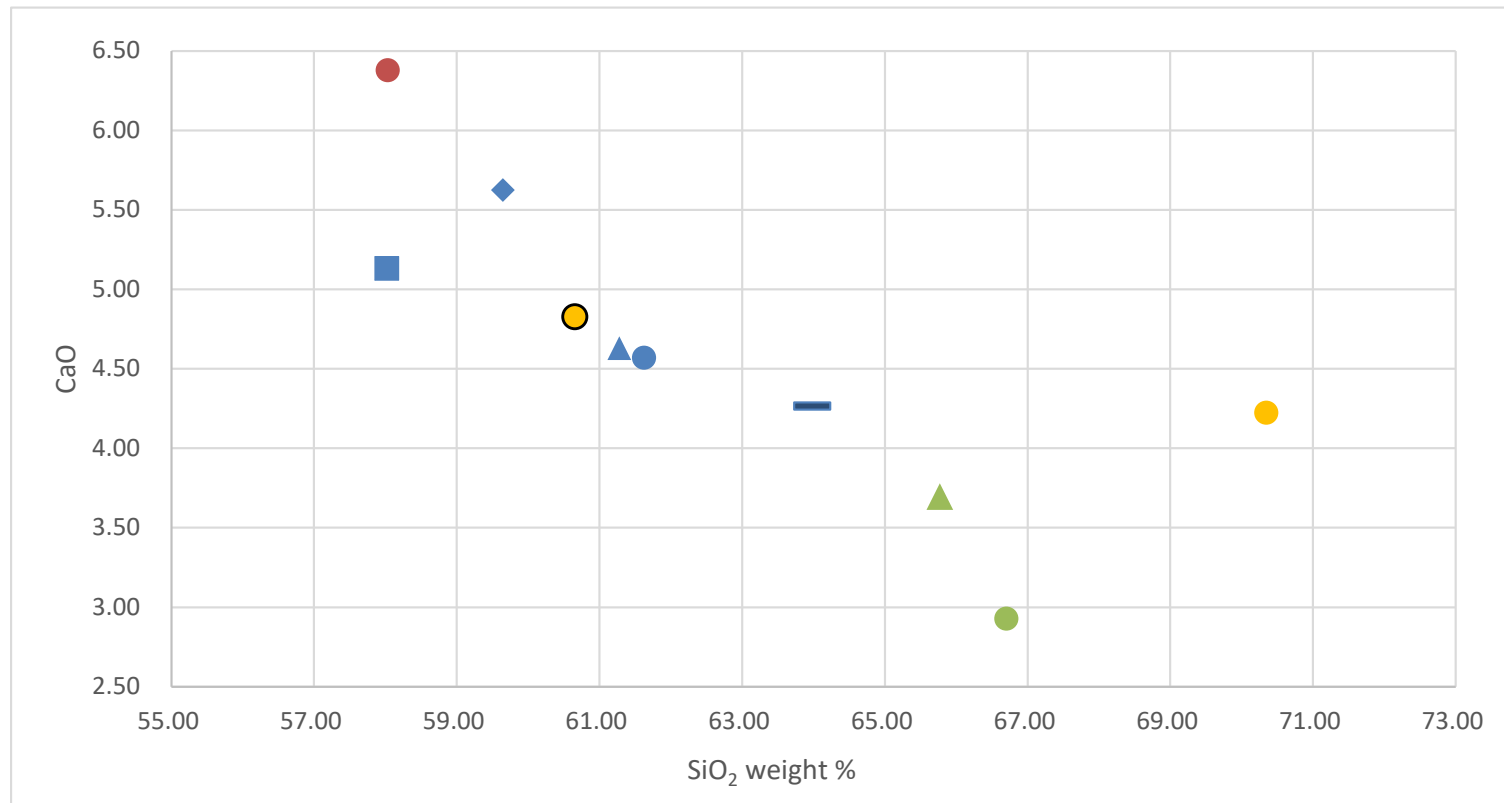

$22 \mathrm{c}-\mathrm{CaO}$

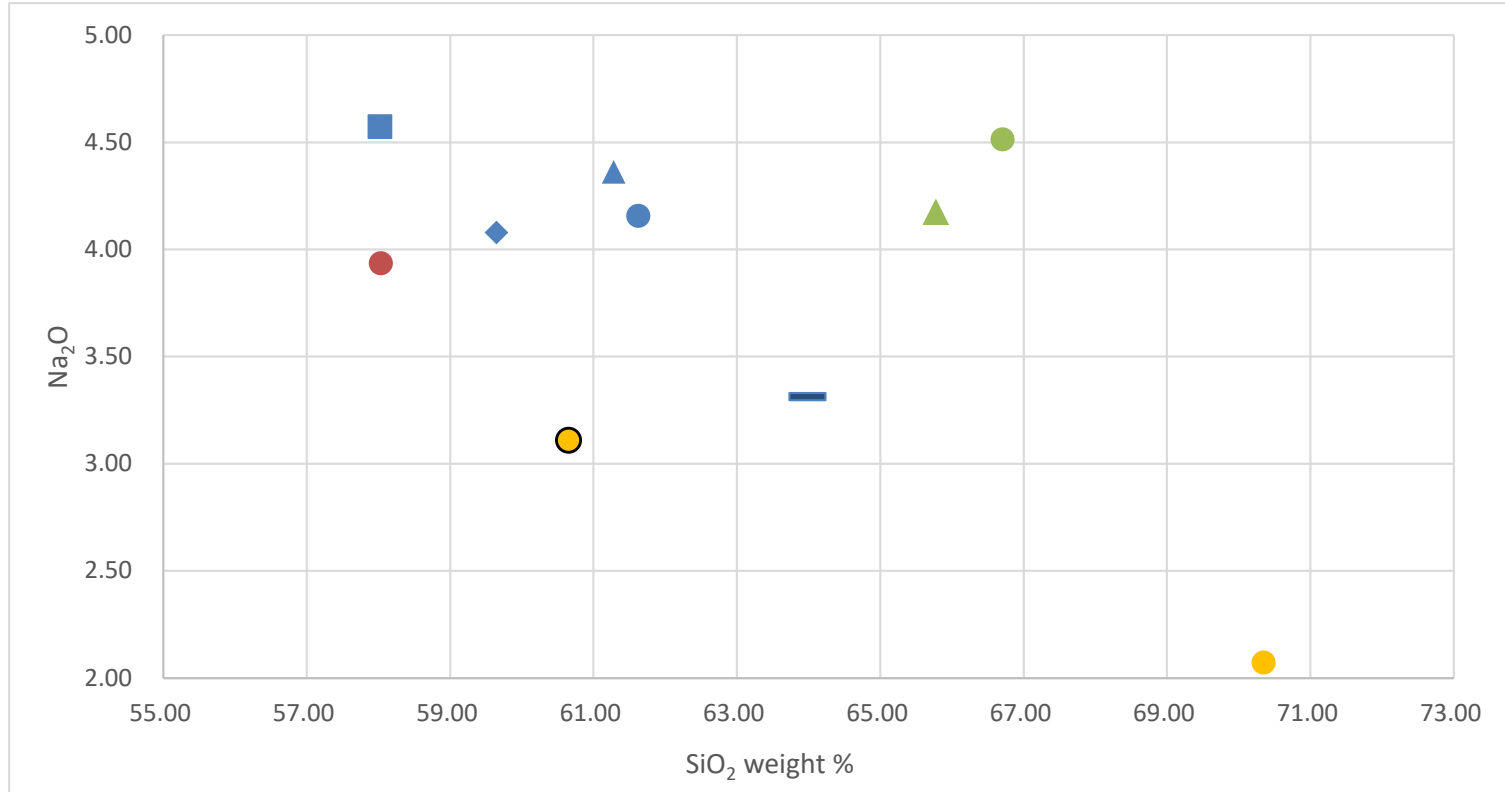

$22 \mathrm{~d}-\mathrm{Na}_{2} \mathrm{O}$ 


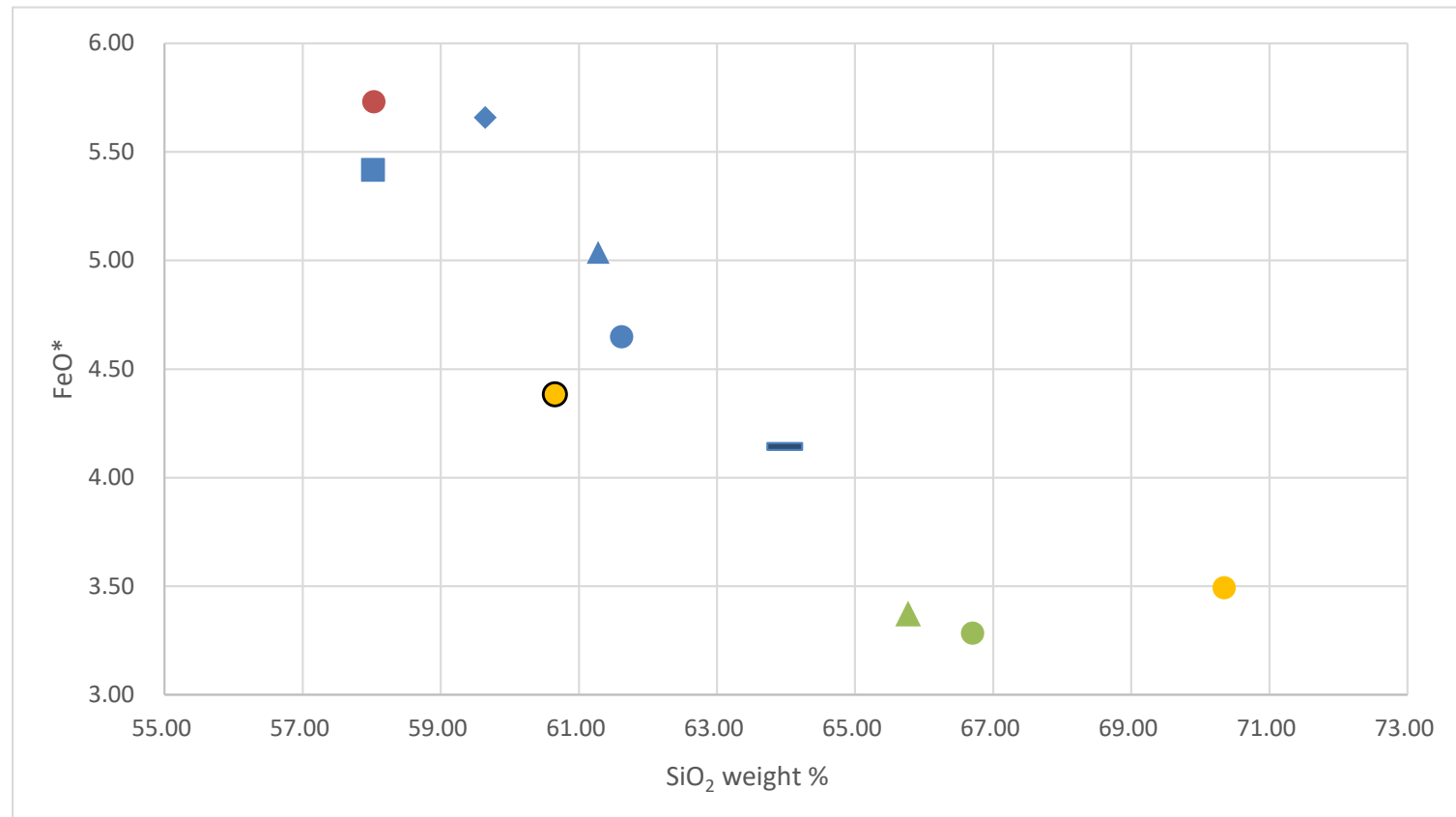

\section{2e - FeO*}

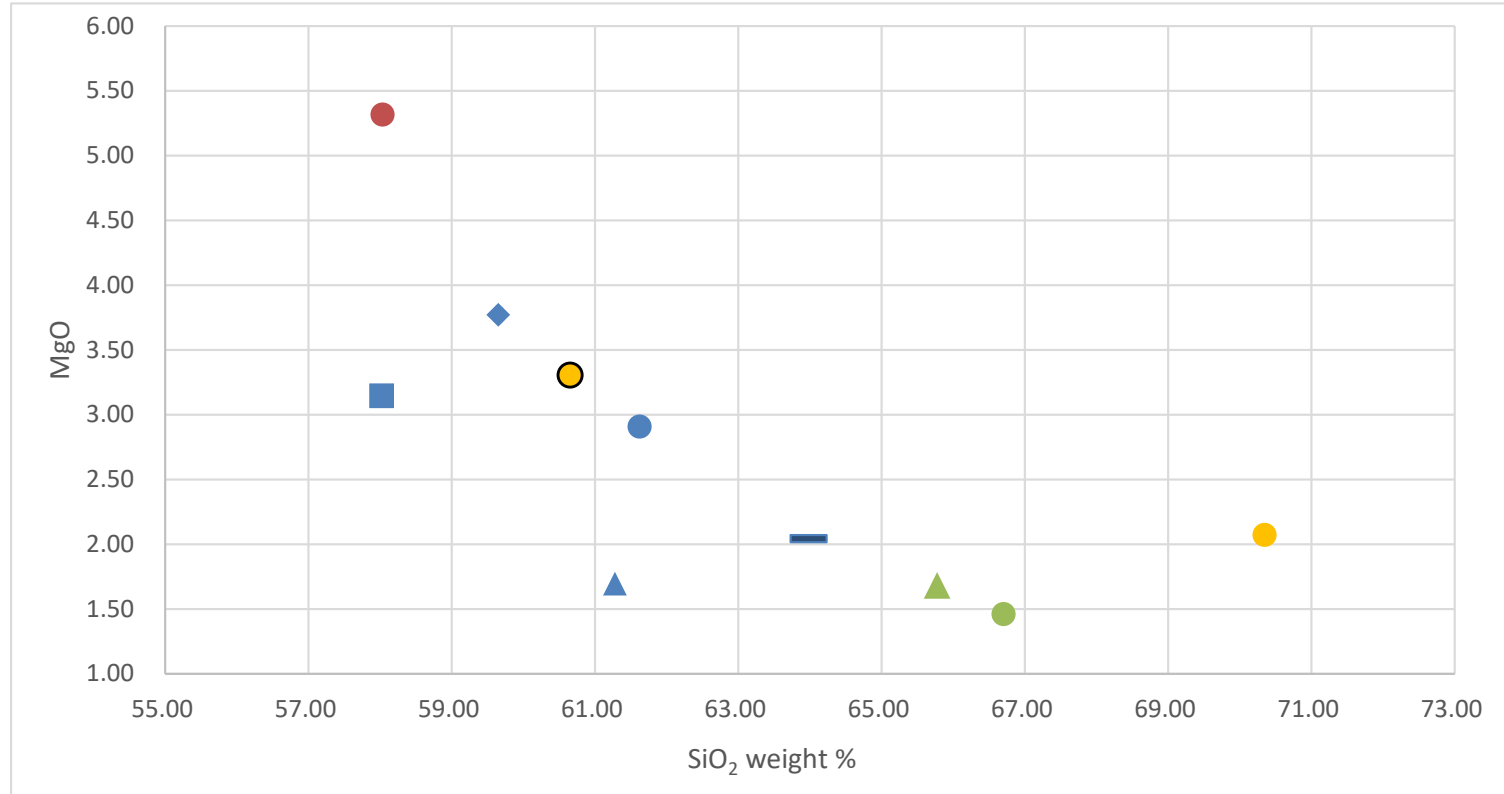

$22 \mathrm{f}-\mathrm{MgO}$ 


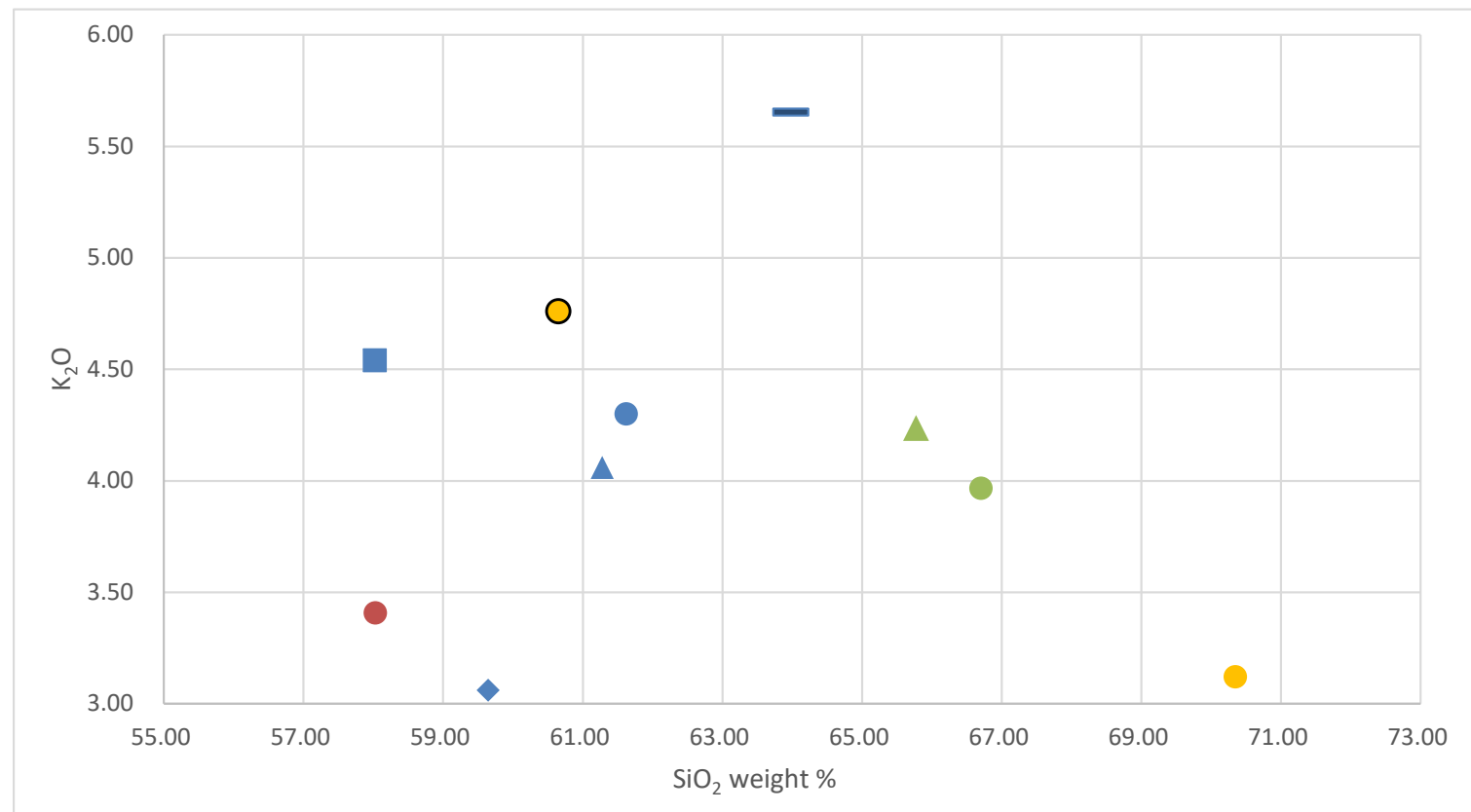

$22 \mathrm{~g}-\mathrm{K}_{2} \mathrm{O}$

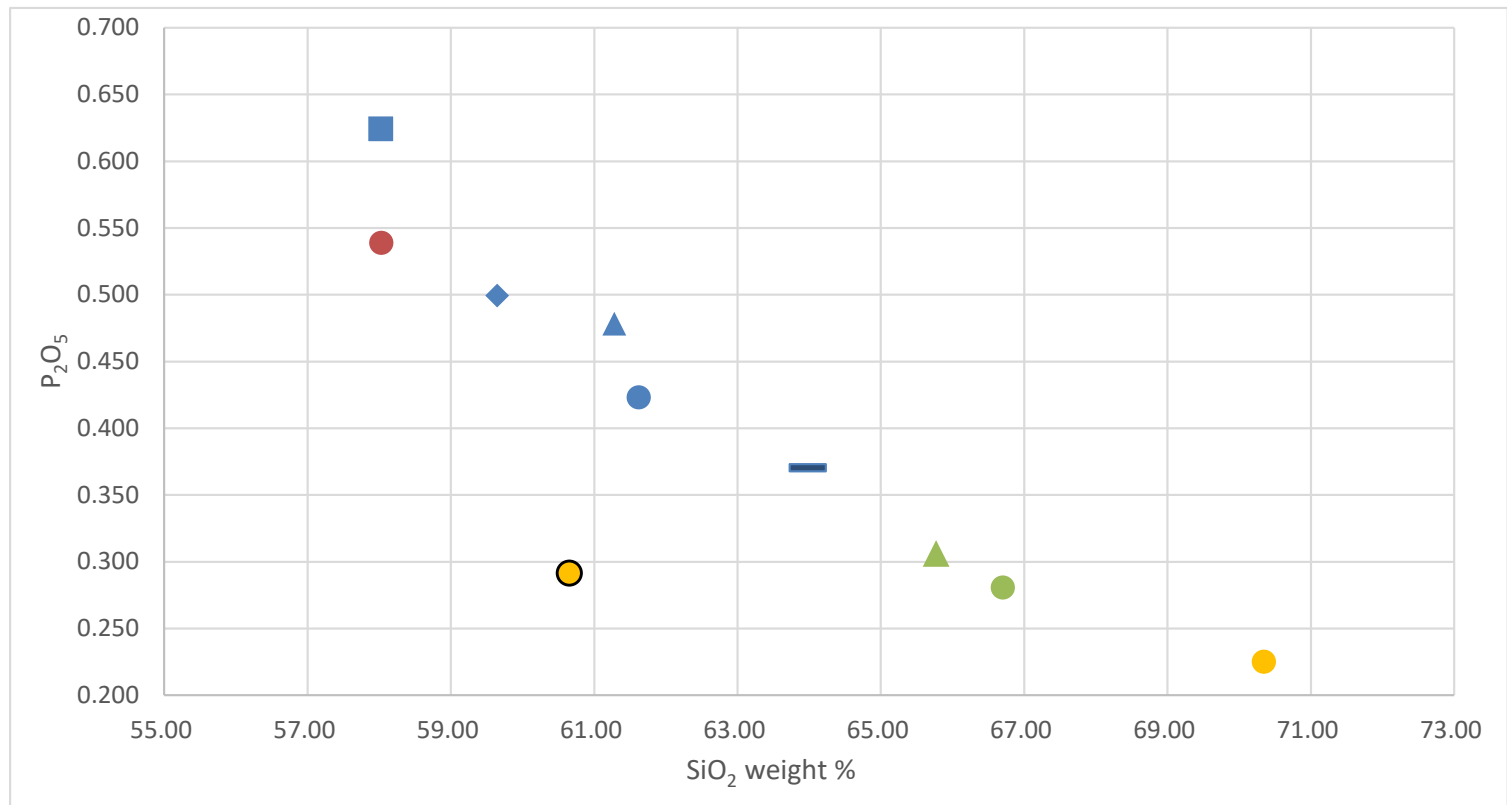

$22 \mathrm{~h}-\mathrm{P}_{2} \mathrm{O}_{5}$ 


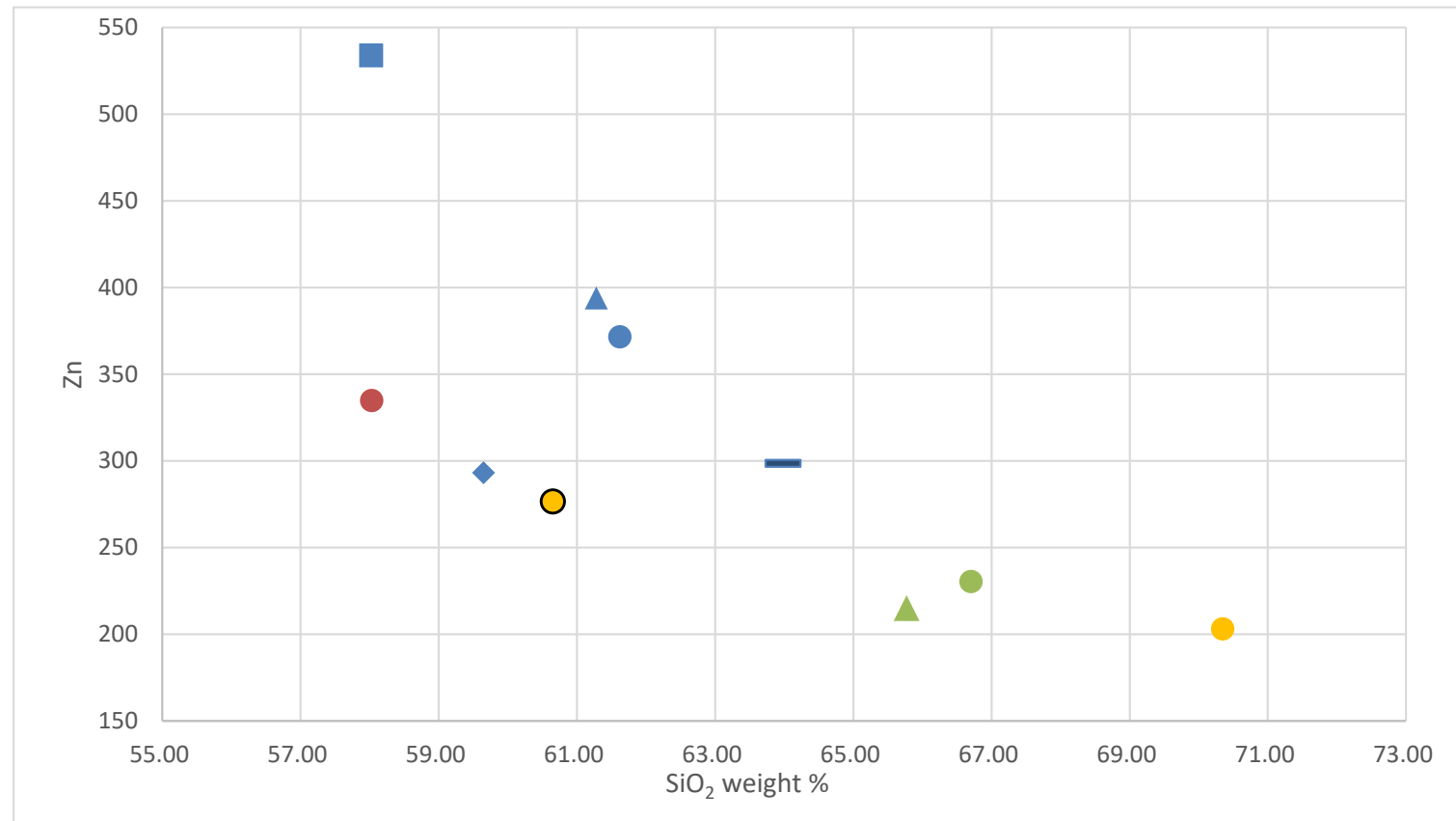

$22 \mathrm{i}-\mathrm{Zn}$

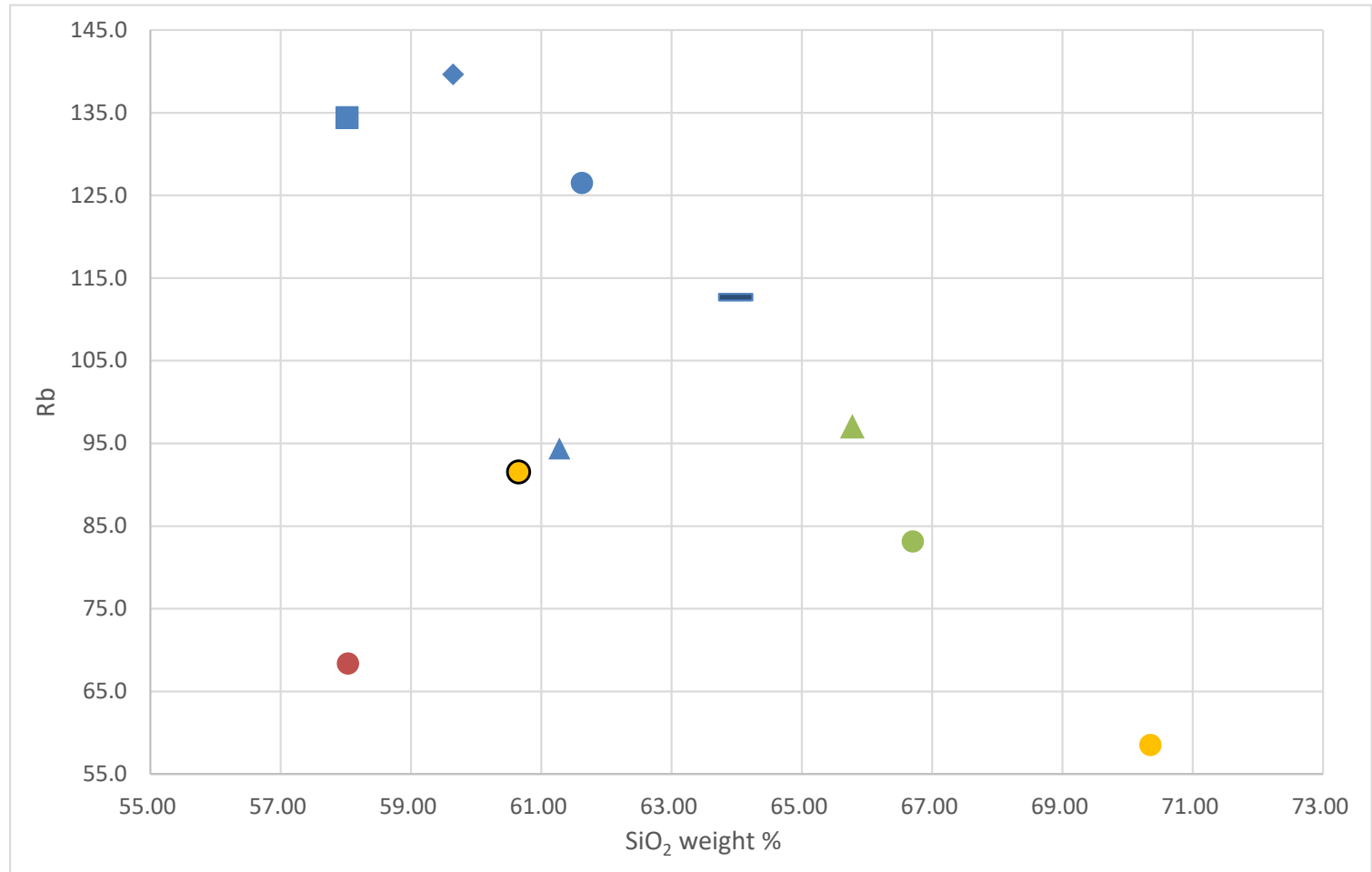

$22 j-R b$ 


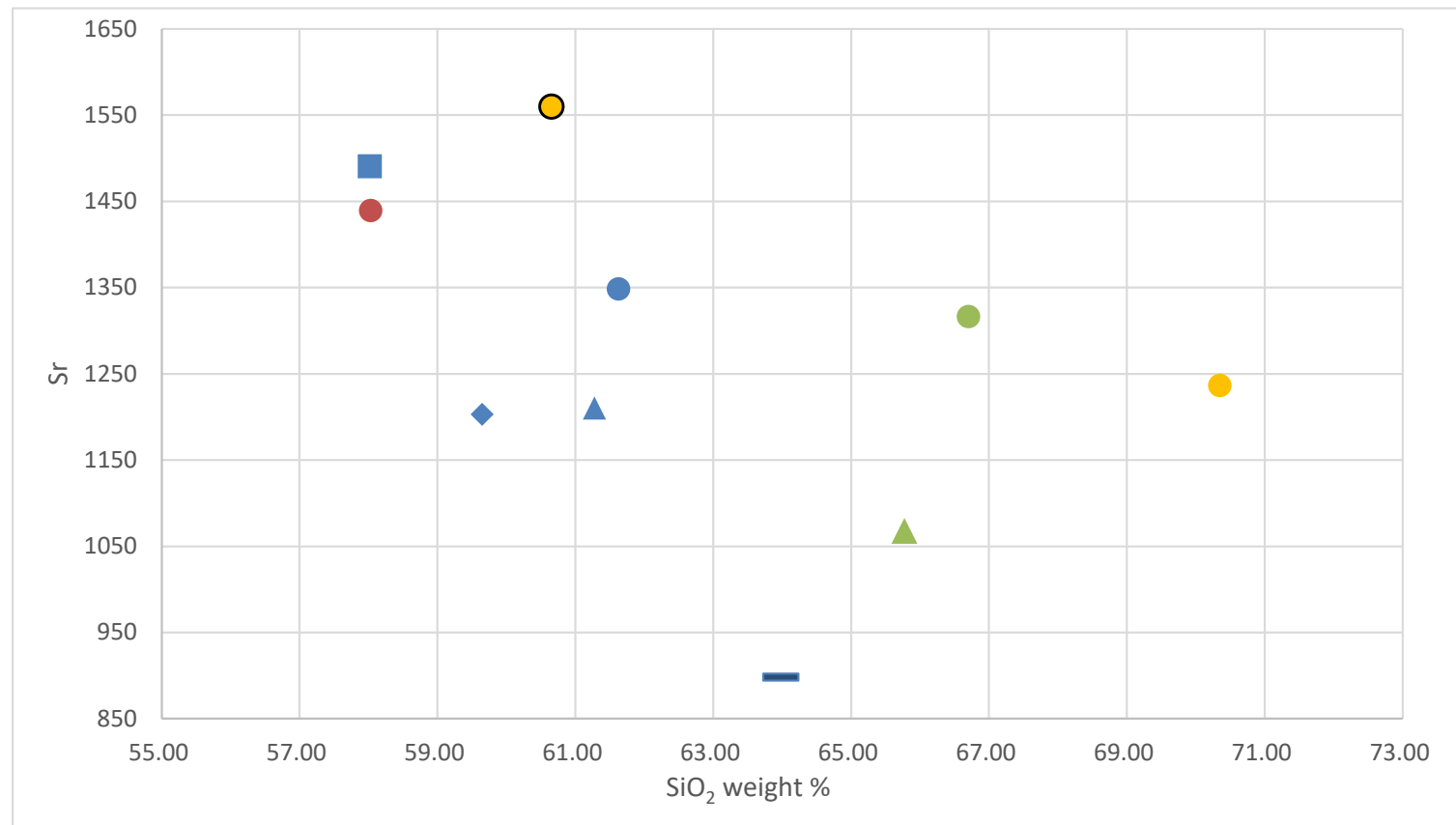

$22 \mathrm{k}-\mathrm{Sr}$

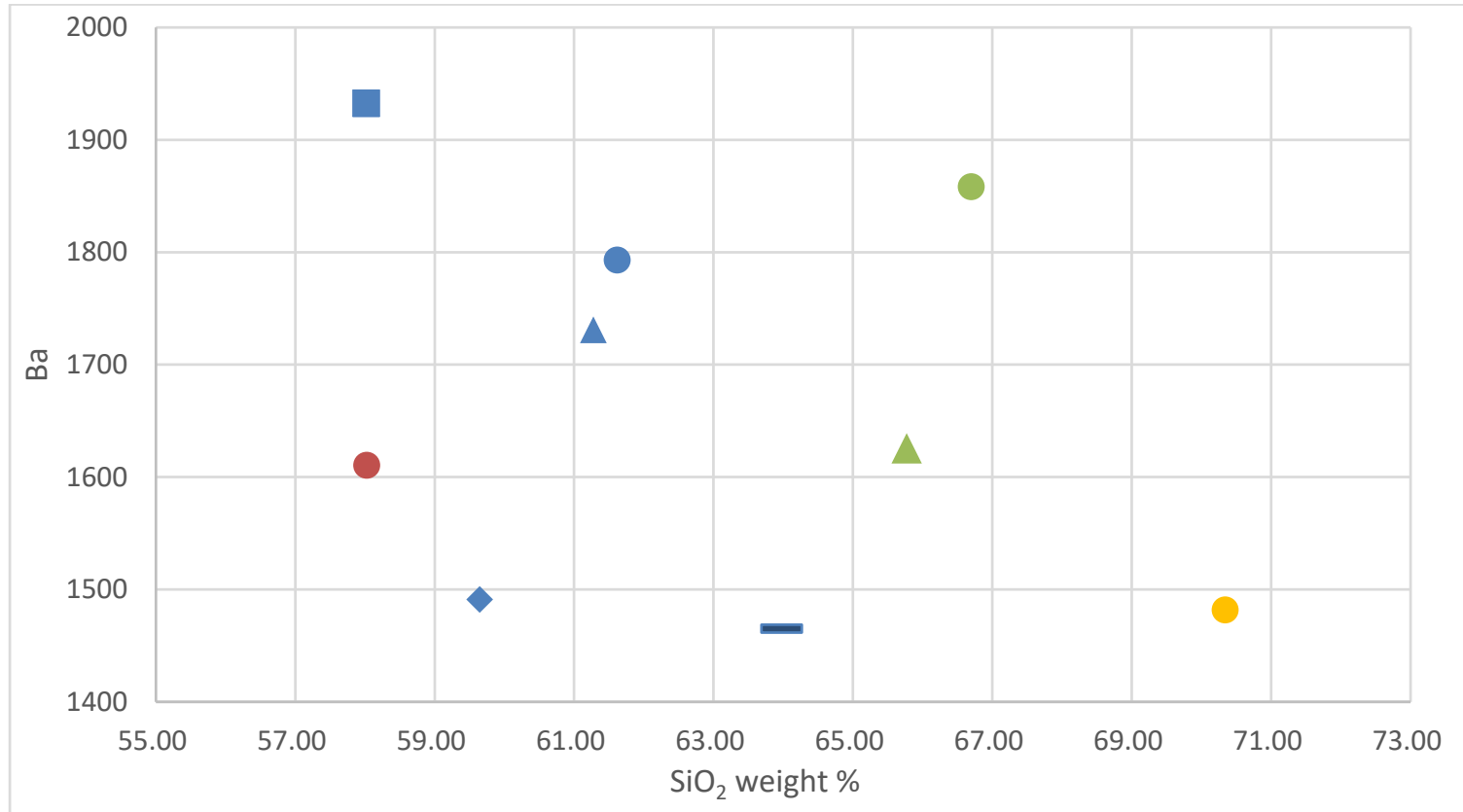

$22 \mathrm{l}-\mathrm{Ba}$ 


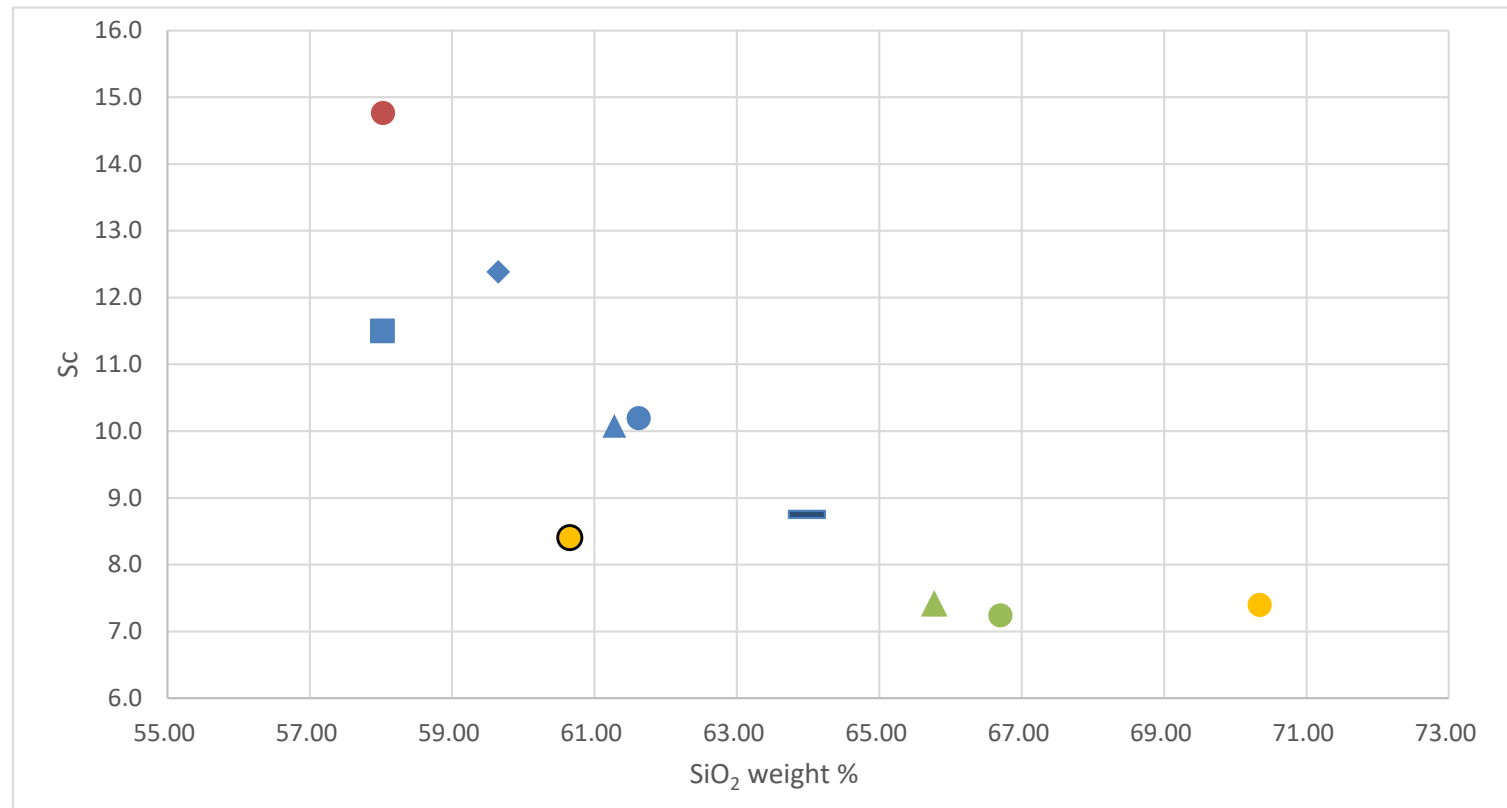

$22 \mathrm{~m}-\mathrm{Sc}$

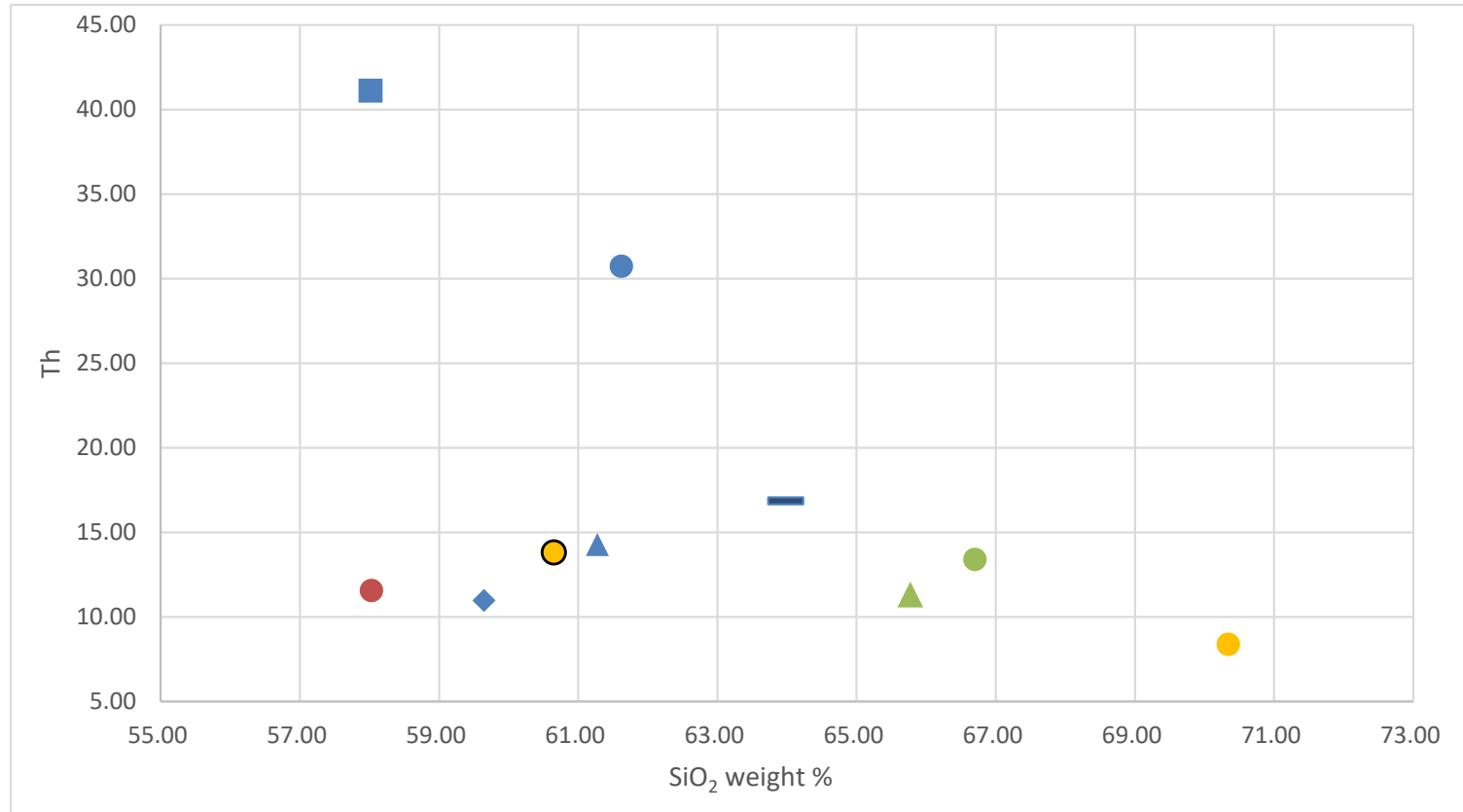

$22 n-T h$

Figures 22a through 22n. Harker diagrams of major and trace oxides. Symbols correspond to legend in Figure 21. 


\section{Trace Elements}

Minor and trace elements normalized to chondrite concentrations exhibit a uniform range and show similar overall patterns with similar chondrite normalized enrichments across the compositional range. The greatest variation is observed in the strongly incompatible elements $\mathrm{U}$ and Th; relatively less variation is recorded in the large ion lithophile (LIL) element’s Ba and Sr (Fig. 23).

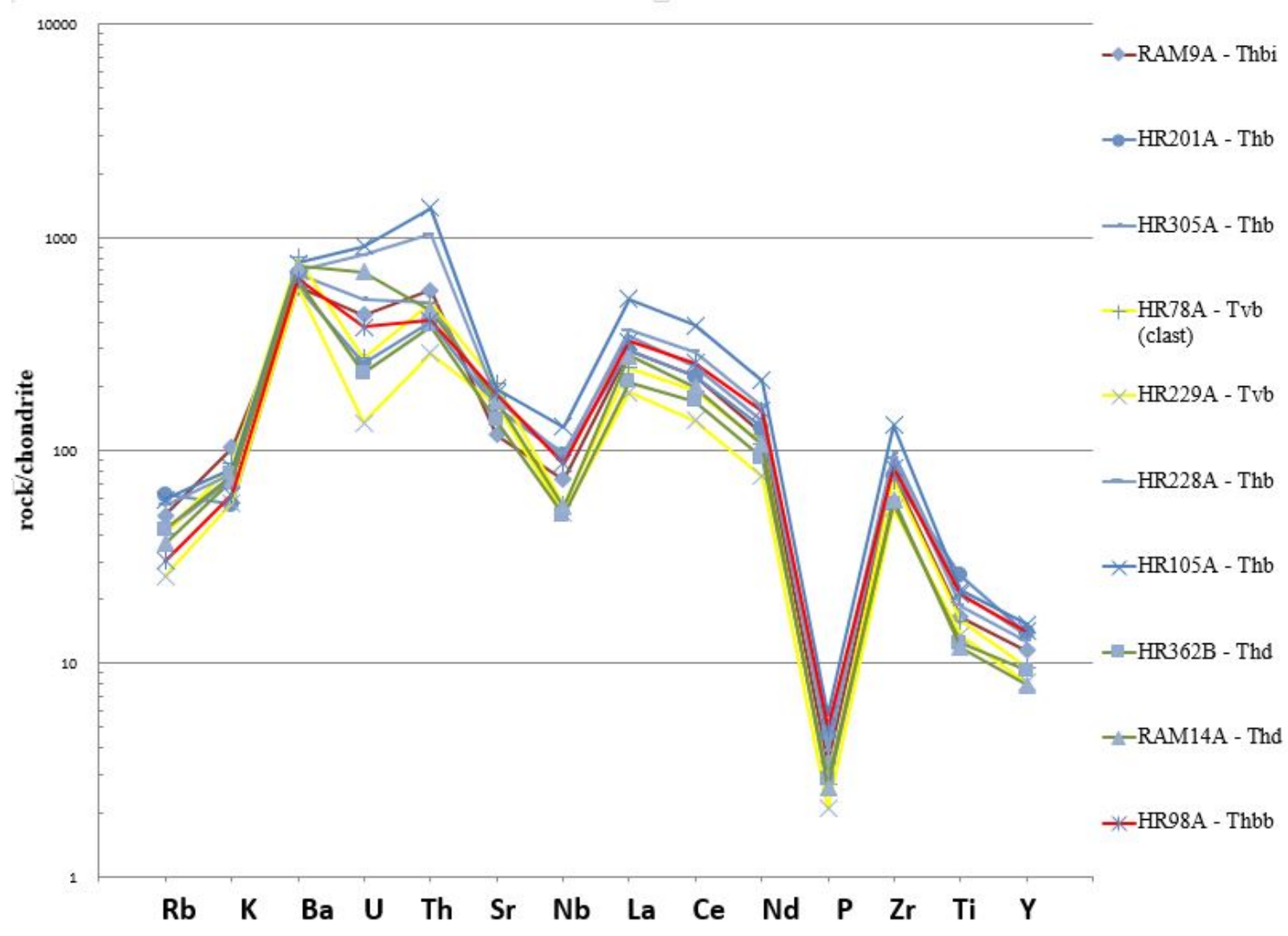

Figure 23. Trace element normalization diagram for northern Highland Range volcanic rocks normalized to chondrite.

Rare earth element plots (normalized to chondrite; McDonough and Sun, 1995)

(Fig. 24) show tightly clustered, relatively straight patterns, with all rocks displaying light 
rare earth element (LREE) enrichment and a small to nearly absent negative Eu anomaly.

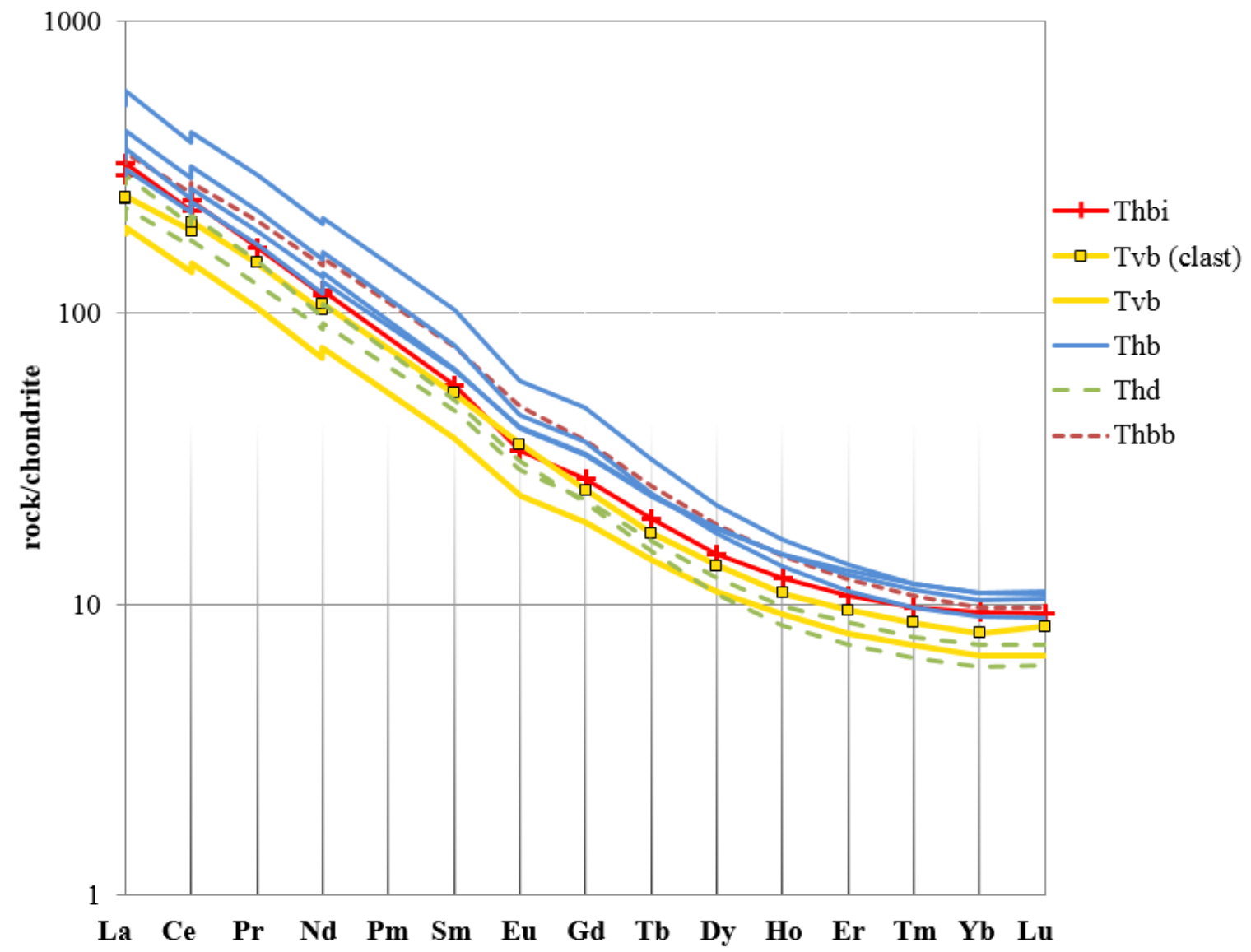

Figure 24. REE normalized to Chondrite from the northern Highland Range. Note very slight Europium anomaly.

\section{STRUCTURE}

\section{Faults}

Faults in the northern Highland Range are predominantly north- to northweststriking with moderate to steep east and west dips (Figs. 25 and 26). Measured fault orientations show over twice as many west-dipping faults as east-dipping with the 
majority of dips ranging from $60^{\circ}$ to $90^{\circ}$; mean dips are $58^{\circ}$ (west-dipping) and $60^{\circ}$ (east-dipping).

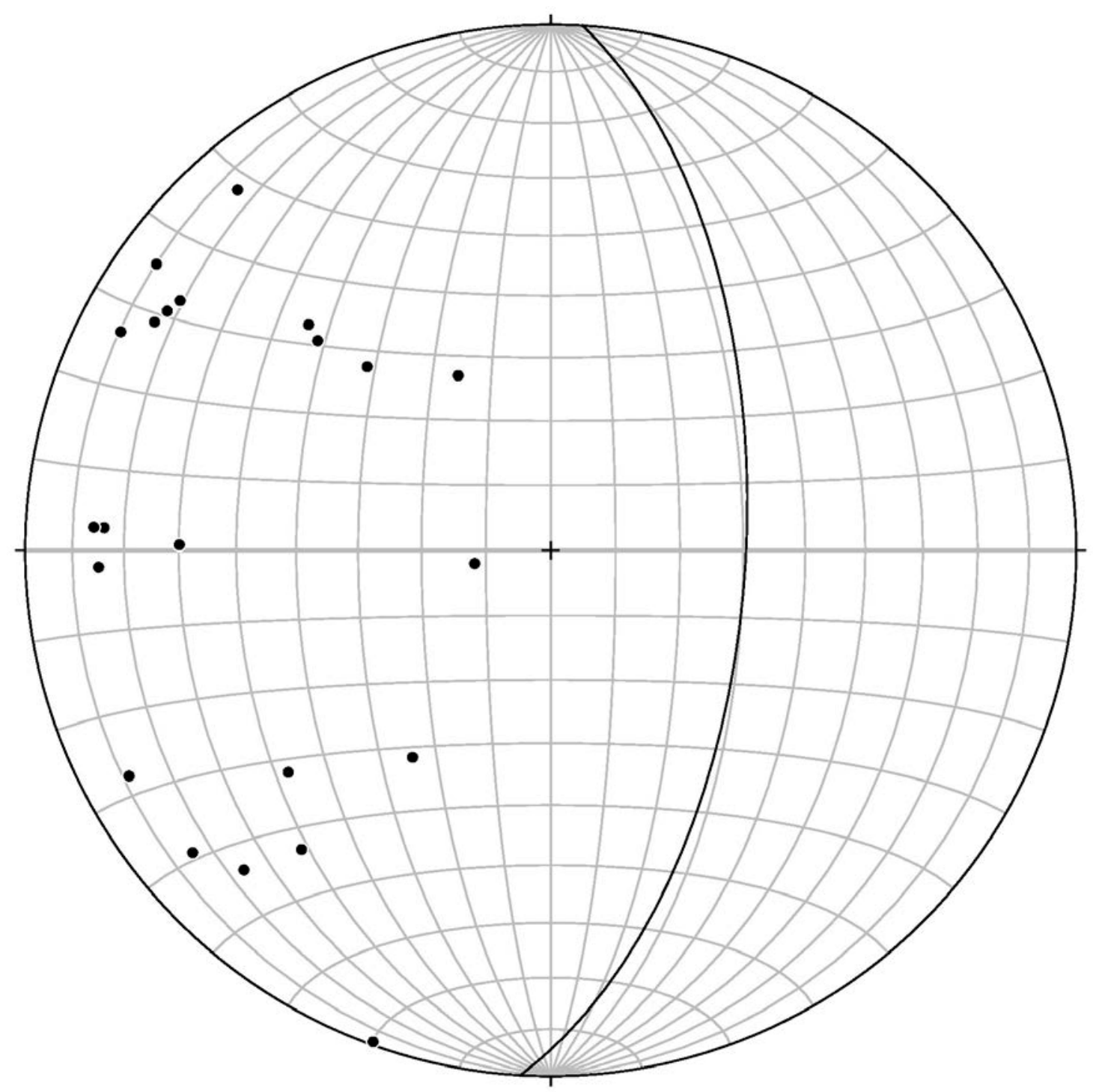

Figure 25. Stereonet plot of east-dipping faults. Equal angle stereonet plot of poles to east-dipping faults with great circle of the mean vector $\left(363^{\circ}, 60^{\circ}\right)$. $\mathrm{N}=22$. All stereonets produced on Stereonet 9.3.0 (Allmendinger et al., 2013, and Cardozo and Allmendinger, 2013). 


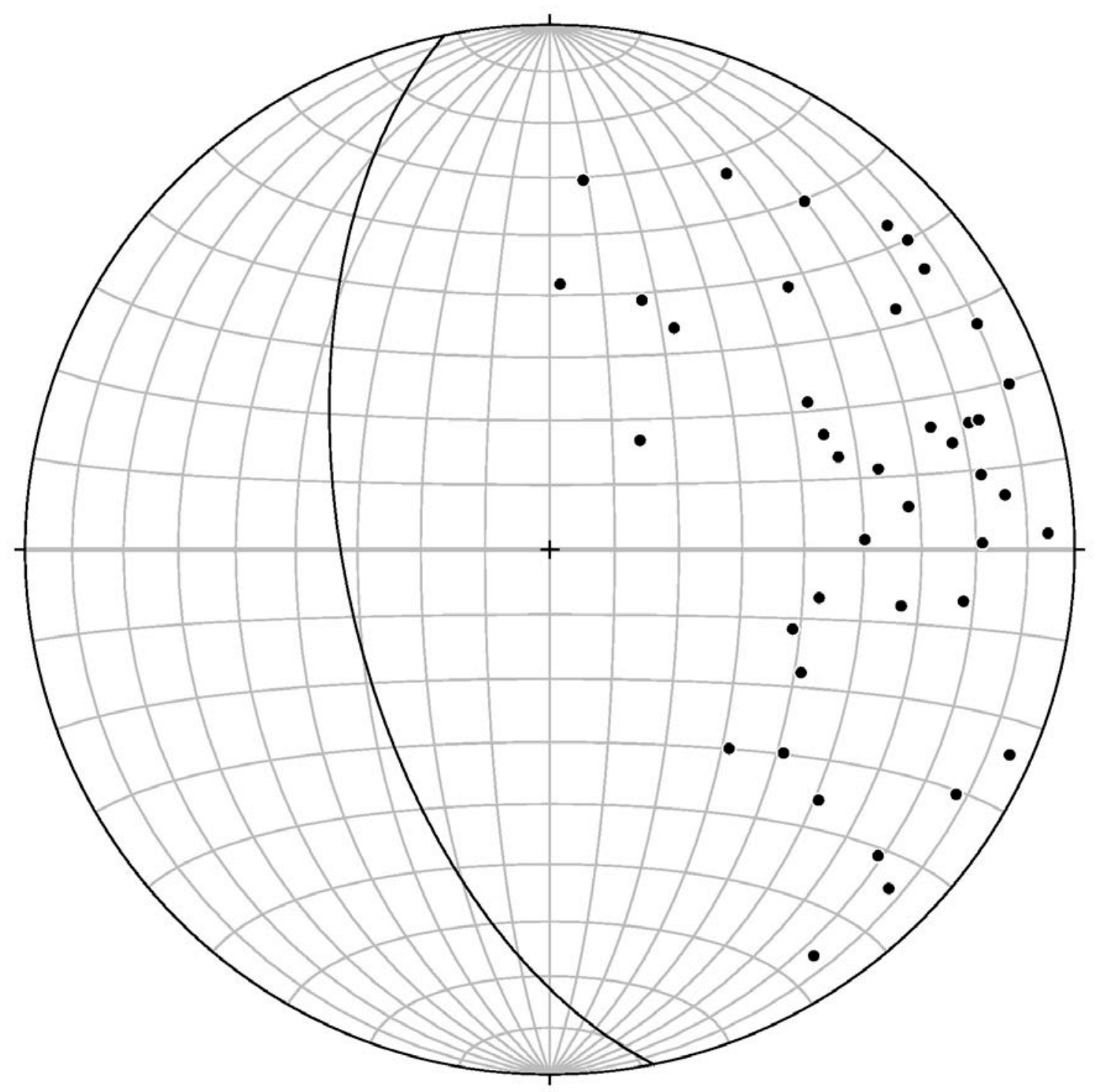

Figure 26. Stereonet plot of west-dipping faults. Equal area stereonet plot of poles to west-dipping faults with great circle of the mean vector $\left(169^{\circ}, 58^{\circ}\right) . n=42$

Normal offset of strata is ubiquitous. A smaller number of faults show normal as well as oblique- to strike-slip motion based on offset beds and sheared clasts within fault planes. Displacement along faults generally increases from east to west. Observed offset in the eastern half of the map area ranged between $1 \mathrm{~m}$ and $20 \mathrm{~m}$. Offset by western 
faults range from $20 \mathrm{~m}$ to $200 \mathrm{~m}$. Fault strike is used to characterize three distinct fault domains, which are defined below.

\section{Fault Zones}

The northern Highland Range can be split into three different fault zones grouped by similar strikes of faults: 1) an eastern zone of north-striking, predominantly west-dipping normal faults; 2) a zone of northwest-striking, alternately dipping normal faults in the southwestern part of the map area; and 3) a northern zone of dominant northeast- and ancillary northwest-striking normal faults (Fig. 27). Major faults in all zones have lengths of $>2 \mathrm{~km}$. Minor faults within each zone ( $<2 \mathrm{~km}$ long) accommodate motion between longer zone-defining faults and generally do not cut major faults. Minor faults for each zone commonly strike oblique to the longer major faults.

The north-striking, predominantly west-dipping Zone 1 faults are similar to faults found in the east-tilted Lake Mead extensional domain (Fig. 28). These north-striking faults continue to the north changing orientation by approximately $45^{\circ}$ and merging into zone 3 faults. To the south of the map area, zone 1 faults appear to die out or are cut off by northwest-striking faults of zone 2 or bend to the east as they near the axis of the anticline and syncline in the central Highland Range (Fig. 3).

Zone 2 faults are a continuation of the system of northwest-striking faults in the central Highland Range that run sub-parallel to the anticline axis (Fig. 2). The axis of the anticline as described by Davis (1984) and Faulds et al. (2001) strikes roughly parallel to the northwest-striking zone 2 faults. Although most zone 2 faults dip southwest towards 


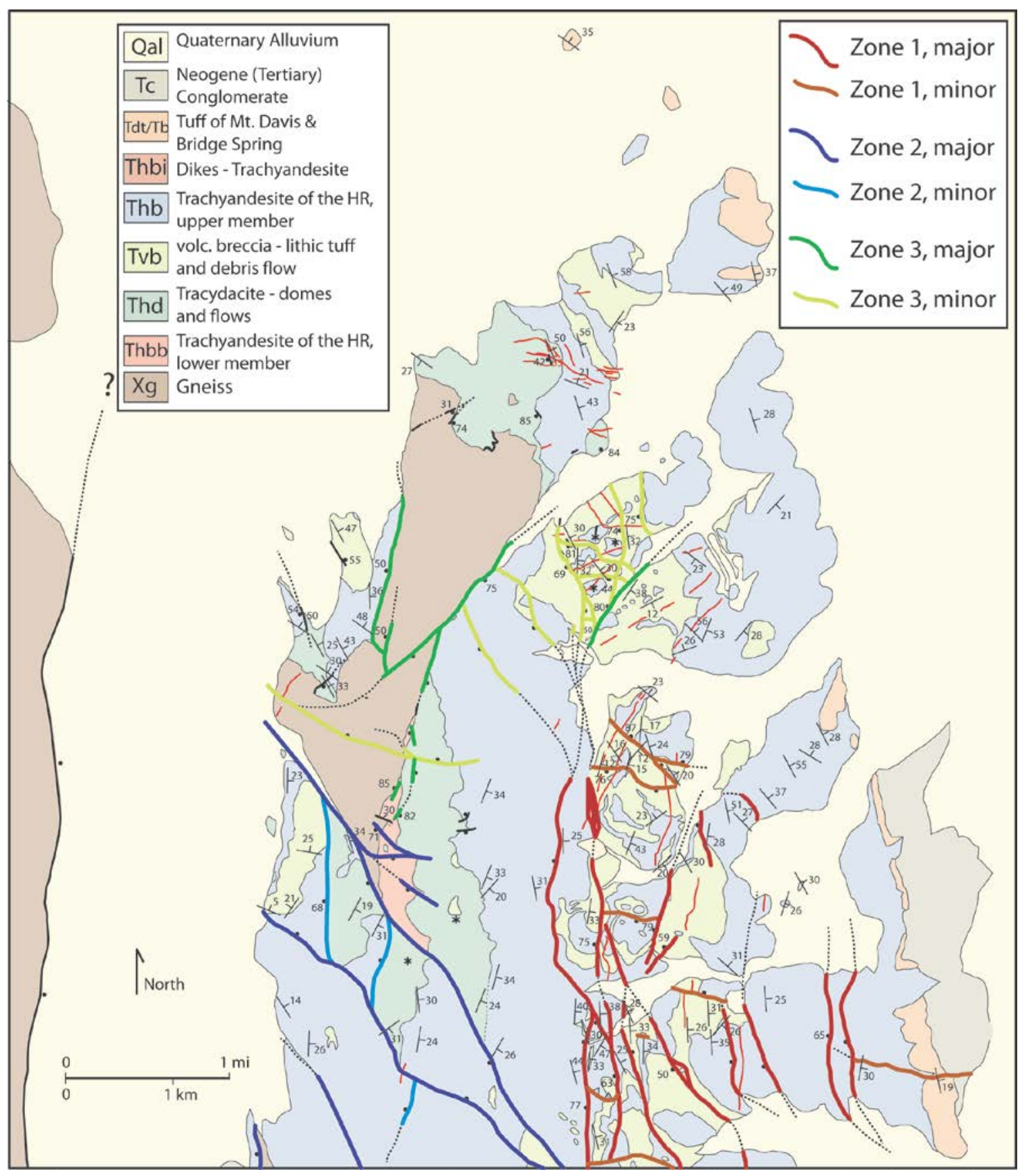

Figure 27. Northern Highland Range fault map. Faults highlighted by zone based on strike.

the axis, some northeast-dipping faults are present and form individual graben within the tilted blocks (Fig. 3; Plate 2). 


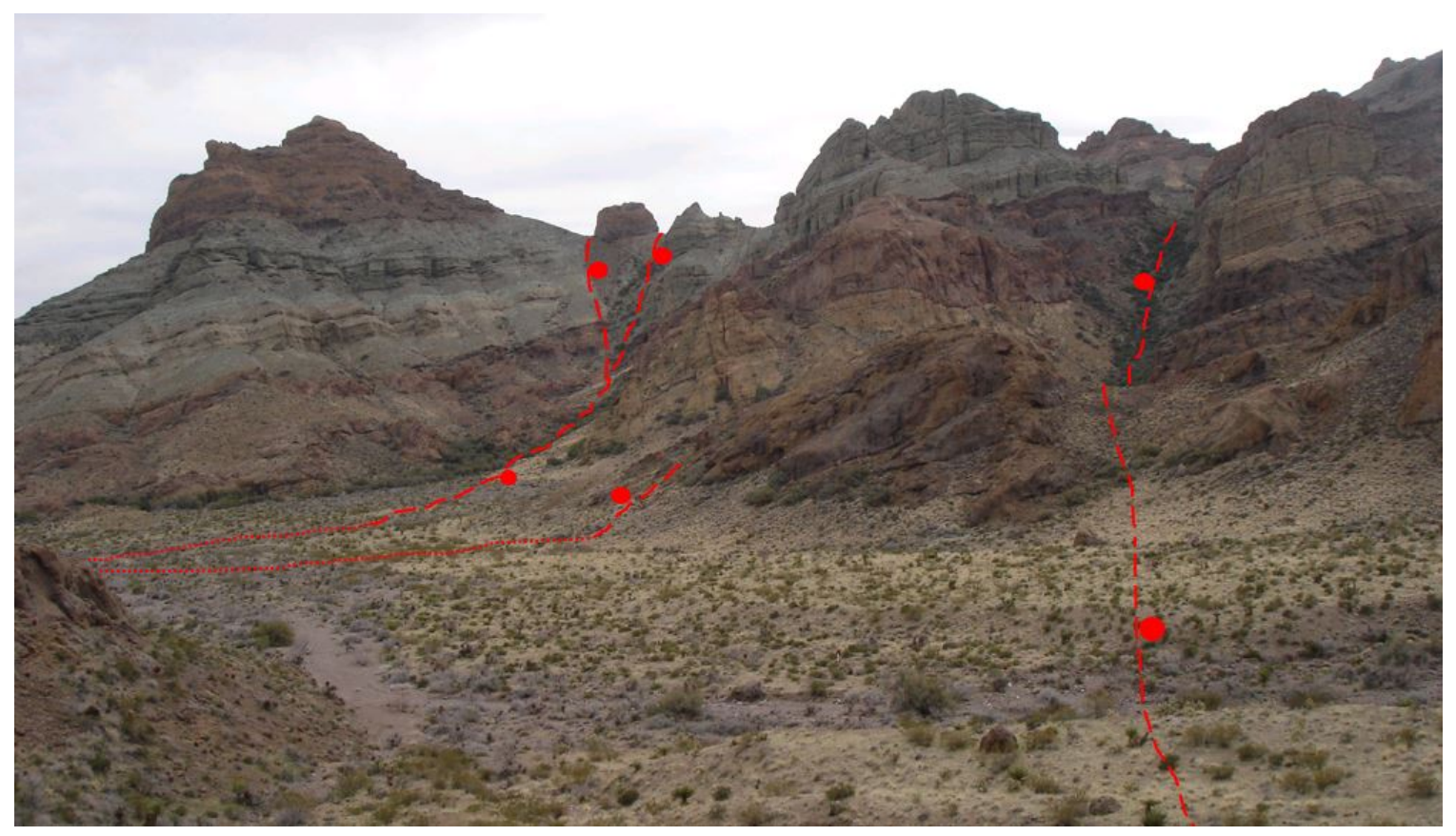

Figure 28. North-striking faults of zone 1. Dashed red lines define normal faults (ball on downthrown side). View to the southeast width is approximately $1 \mathrm{~km}$ wide.

A graben formed between two oppositely tilted northwest-striking faults within zone 2 is observed west of the "Main Central Ridge” (Plate 1). North-striking, west-dipping normal faults within the graben separate repeated sections of stratigraphy. Field observations of fault displacement exhibit only tens of meters of slip, but cumulative displacement of several hundred meters with increasing slip from east to west is inferred and results in juxtaposition of volcanic breccia in the western most block (Tvb within Thb) against the basement orthogneiss (Xg).

Zone 3 faults are defined by, and can be organized into, the two subgroups based on these characteristics: northeast-striking major normal faults accommodate tens of meters of slip, and north- and northwest-striking minor normal faults accommodate lesser amounts $(<20 \mathrm{~m})$ of slip. 
Oppositely dipping normal faults in the northern half of the range (in zone 3) bound the east side of a structural horst. Starting at latitude $3948000 \mathrm{~m} \mathrm{~N}$ the two horstbounding faults place trachydacite (Thd) next to orthogneiss (Xg) (Plate 1). As the faults are traced to the north the sequences of basaltic trachyandesite (Thb) and volcanic breccia (Tvb) lie across the eastern bounding fault from orthogneiss and trachydacite. This horst of orthogneiss has increasing amounts of slip along either side as the faults progress to the north and northeast.

\section{Orientation of Strata}

Attitudes of bedding measured from lava flows, volcanic breccias, tuffaceous sandstones, lahars, and debris flows, generally dip from $10^{\circ}$ to $40^{\circ}$ to the east (Fig. 29). Variations from the uniform bedding dips can differ from $5^{\circ}$ to $15^{\circ}$ in a localized area. Lava flows, breccias, debris flows, and volcanic breccia sequences presented erratic and west-dipping bedding attitudes as they filled and covered uneven paleotopography or mantled volcanic domes and/or steep-sided flows. The trachydacite unit (Thd), in particular, contains considerable variability in bedding strike and dip especially where younger flows and breccias mantle older, steep-sided domes and flows. Other west-dipping beds show drag near faults; small blocks of west-dipping strata occur locally between closely spaced, steep normal faults. Numerous minor faults within zone 3 produce variation of bedding orientations within the thickest section of the volcanic breccia (Tvb) (Fig. 27). 


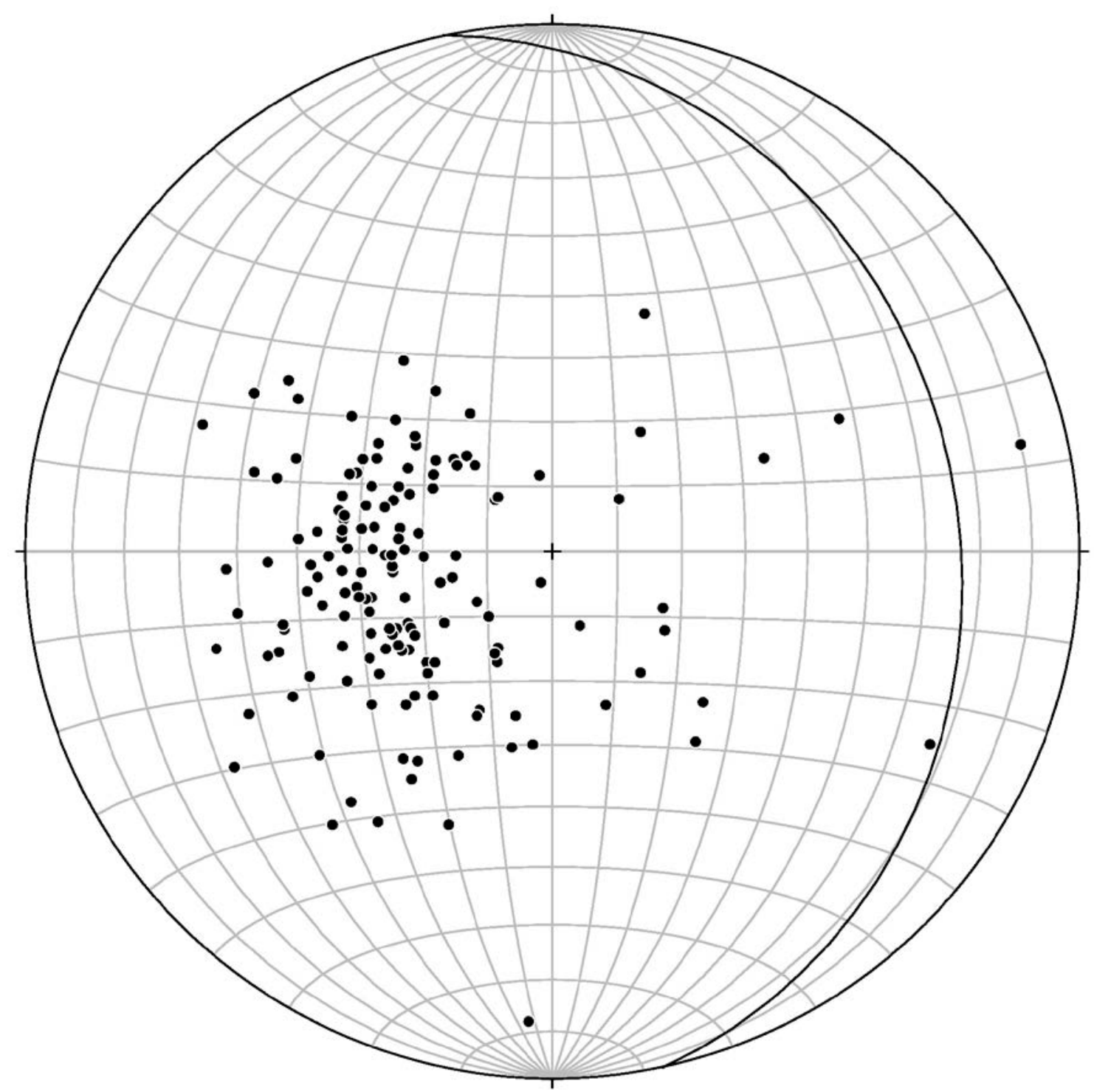

Figure 29. Stereonet plot of bedding. Equal area stereonet plot of poles to bedding with great circle of the mean vector $\left(348^{\circ}, 24^{\circ}\right) . n=147$

Bedding attitudes of Miocene volcanic rocks were divided into upper and lower groups with the middle of the volcanic breccia (Tvb) as the divide. This lithologic change was an ideal division to compare younger and older bedding spanning potentially 2.8 million years (Fig. 30). Dips and attitudes of younger and older Miocene volcaniclastic strata display no significant variation when plotted on a stereonet. 


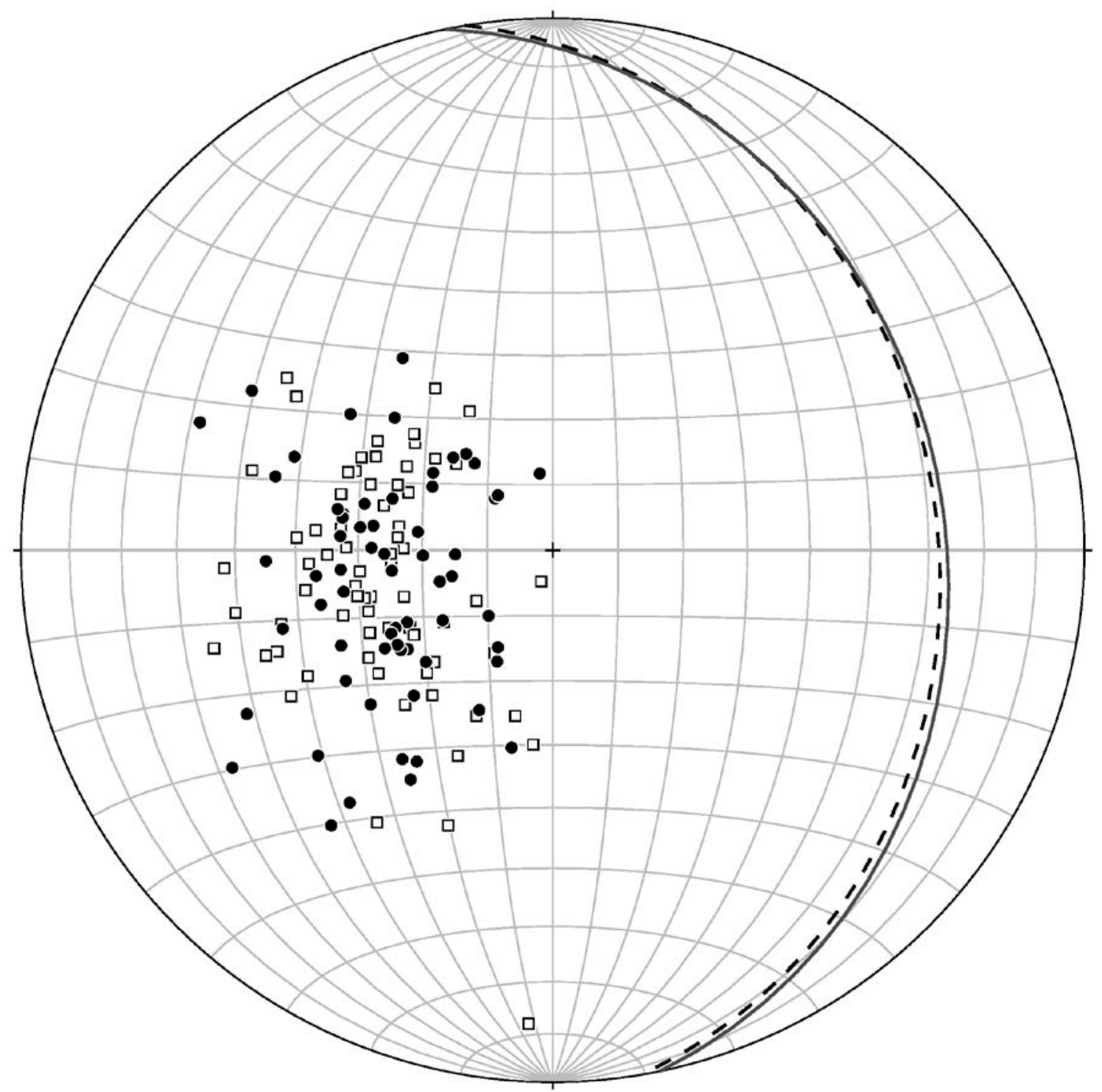

Figure 30. Stereonet comparing upper and lower east-dipping bedding attitudes. Equal area stereonet plot of poles to lower (squares) and upper (circles) bedding with great circles of the mean vector: lower (dashed, $351^{\circ}, 29^{\circ}$ ), and upper (solid, $348^{\circ}, 27^{\circ}$ ). $n=81$ and $n=63$; respectively.

\section{Dikes and Vents}

Many dikes are visibly continuous from $100 \mathrm{~m}$ to more than $1000 \mathrm{~m}$ striking from north, northeast, west and northwest (Fig. 31). Dikes range in thickness from less than $1 \mathrm{~m}$ to $12 \mathrm{~m}$. Dike thickness can vary along strike; at times thinning to nothing, cut 
off by faults, or thinning into an adjacent, sub-parallel fault. Dikes exposed east of the main central ridge and on the western end of the northern ridge are commonly associated with, and generally oriented subparallel to, major and minor faults of zones 1 and 3. Dike orientations generally strike north in the south and rotate to northeast to northwest in the north (Fig. 18). West-dipping dikes ( $\mathrm{n}=20$ ) have an average dip of $68^{\circ}$, and east-dipping dikes ( $\mathrm{n}=12$ ) have an average dip of $72^{\circ}$ (Fig. 32).

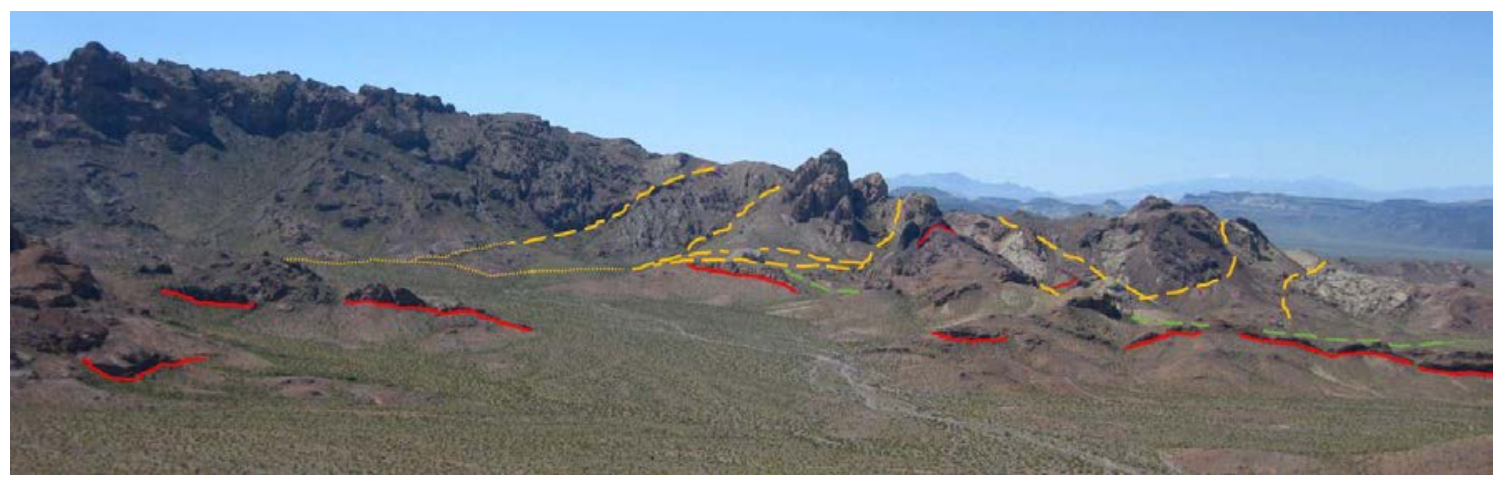

Figure 31. Dikes and faults on the northeast side of the map area. Red lines define dikes. Dashed lines define faults of zone 3: green (major) and yellow (minor). View is approximately $3 \mathrm{~km}$ wide and to the northwest.

A vertical dike or small plug (Thbi) that appears to feed ridge-capping lava flows (Thb) and intrude subjacent trachyandesite flows/autobreccias (Thb) and volcanic breccia (Tvb) (Fig. 33) occurs in one excellent exposure within the center of the range.

\section{DISCUSSION}

\section{Volcanic Stratigraphy, Facies Relationships and Correlation}

The northern Highland Range volcanic rocks consist of a thick (>3,000 m) sequence of trachydacite and trachyandesite lavas intercalated with a non-welded, dacite/rhyolite lithic tuff and many associated minor debris flows and tuffaceous sandstones. 
Lava flows and clasts and matrix within the volcanic breccia of the northern

Highland Range can be divided into trachyandesite and trachydacite groups. The

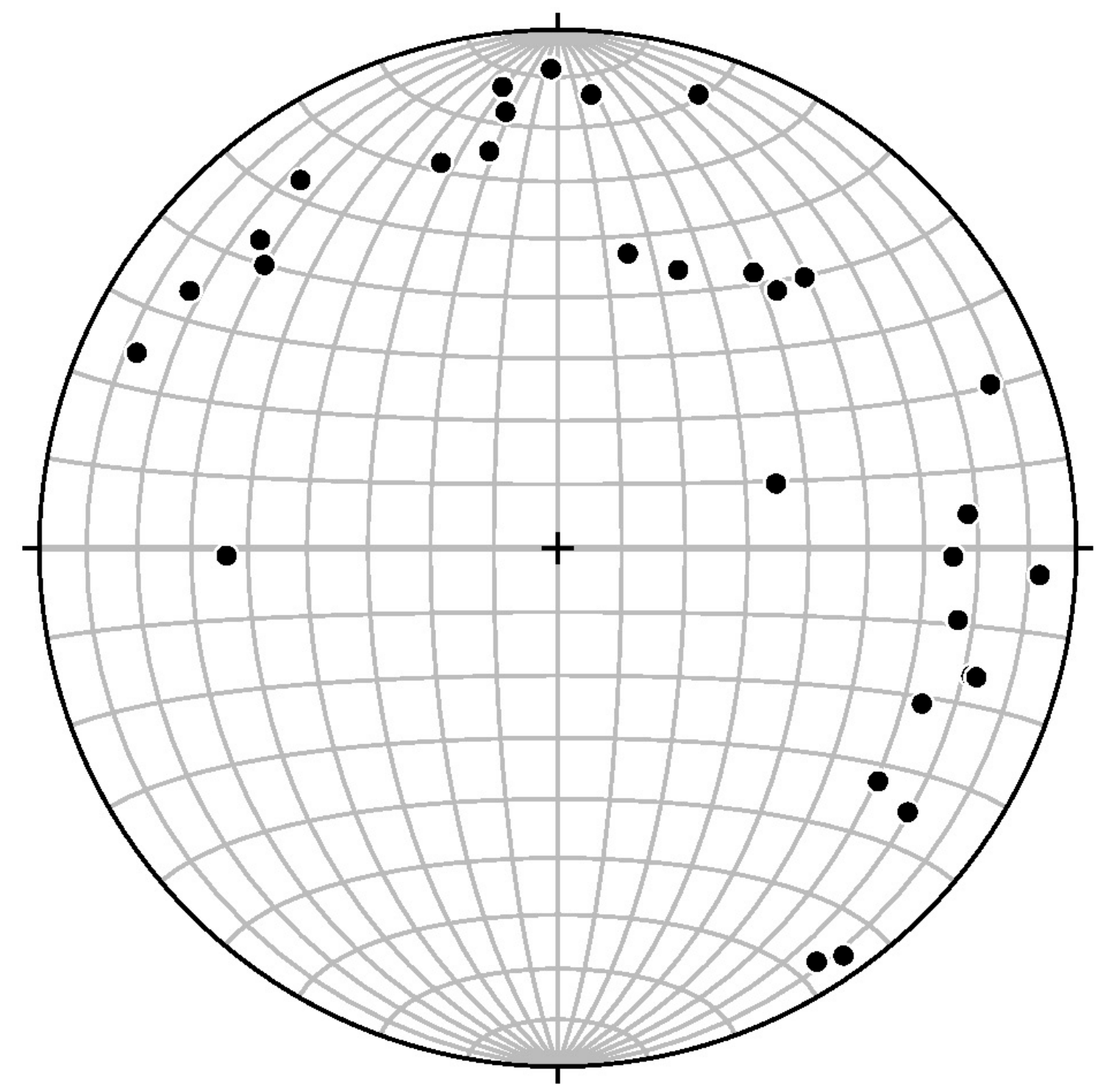

Figure 32. Stereonet of poles to dikes. $(\mathrm{n}=32)$ 


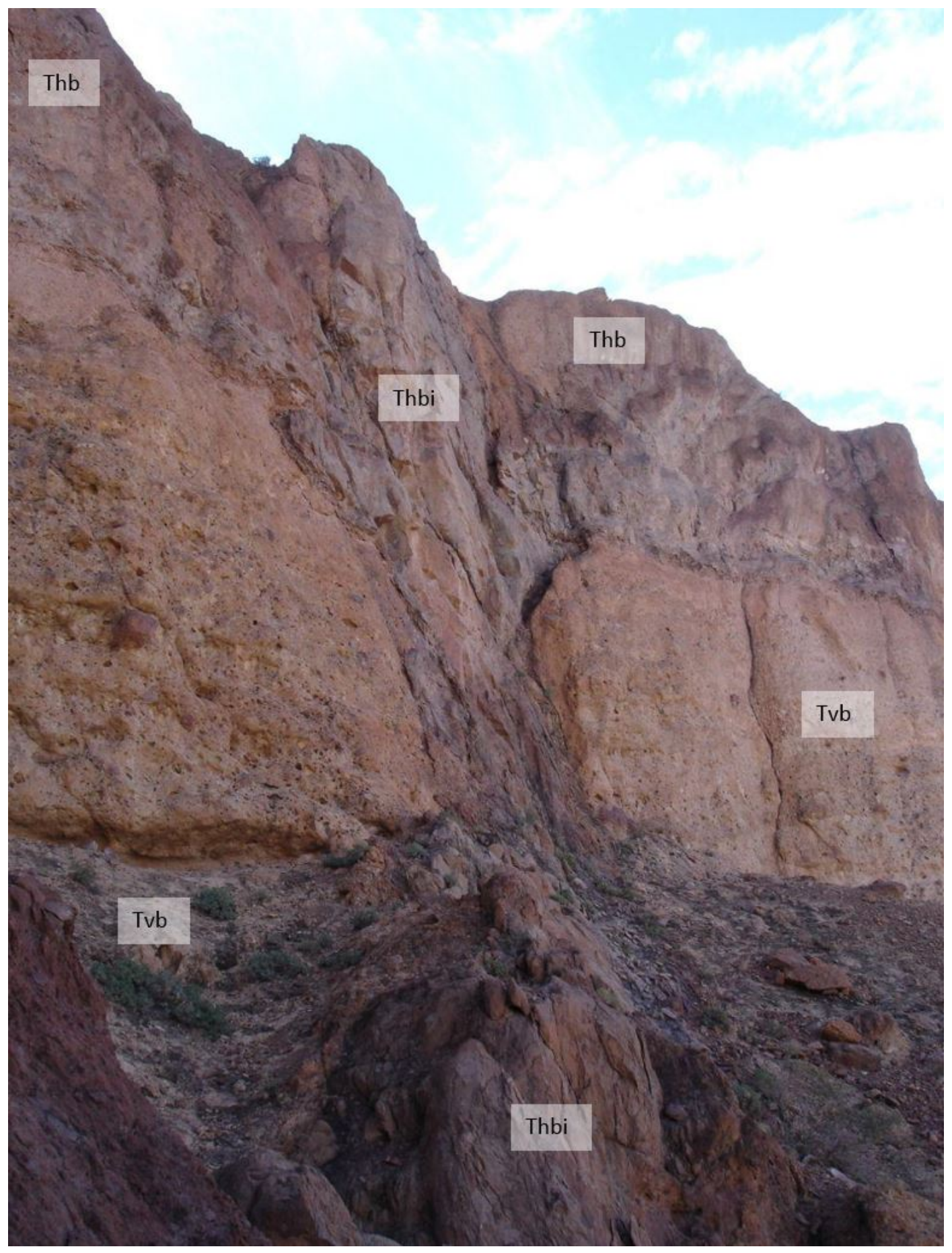

Figure 33. Trachyandesite dike or plug. Thbi rock intruding through buff-colored volcanic breccia (Tvb) and appearing to feed laterally into overlying lava flows (Thb). 
trachyandesite group includes the units Thbb, Thb, and multiple dikes (based on field mineralogy). The trachydacite group includes the unit Thd, a dike (based on whole rock analysis), and the matrix from Tvb; many clasts within the matrix appear similar to trachyandesite lavas. Whole rock analysis for this study focused on identifying rock types to compare to other volcanic sequences in the region (Fig. 21).

In the northern Highland Range, the intermediate to felsic volcanic breccia unit ( $\mathrm{Tvb}$ - trachydacite matrix) is sandwiched between mafic to intermediate sequences of basaltic trachyandesite (Thb), with a trachydacite unit (Thd) and a uniquely aphyric basaltic trachyandesite (Thbb) forming the basal part of the section.

Parts of the central and southern Black Mountains (Varga et al., 2004), the Mount Perkins region (Faulds et al., 1995), and the southern Highland Range (Faulds et al., 2002a) have sections of Miocene rhyolitic lavas and/or tuffs that occur stratigraphically between sequences of intermediate lava, but in detail the stratigraphy and volcanic facies of the northern Highland Range appear to be relatively unique and limited in stratigraphic extent.

Basal units Thbb (basal basaltic trachyandesite) and Thd (trachydacite) constitute only the lower ca. $200 \mathrm{~m}$ of volcanic strata, and both units appear to taper to the north and south. The modest total thickness and volume of these units suggest that they are probably local to the northern Highland Range (Plate 1). The aphyric to very sparsely porphyritic texture of Thbb in particular is a unique feature, and no similar texture is reported for rocks in previous work by Davis (1984), Olsen (1996), Faulds and Bell 
(1999), and Faulds et al. (2002a; 2002b) in the central or southern Highland Range. No vent source was identified for Thbb in the map area.

There is clear evidence of local derivation of trachydacite unit Thd. Multiple brecciated domes mark the vent sources for adjacent trachydacite flows (two asterisks near latitude 3,945,500 m N on Plate 1 and Fig. 8). Trachydacite domes and associated flows likely created a localized, $170 \mathrm{~m}$ thick, volcanic lava flow and dome field that constituted the first significant pulse of magmatism in the northern Highland Range. These breccia domes and flows created an undulating topography on which overlying lithic tuff and minor andesitic flows were deposited. Unit Thd also tapers along strike, but is obscured by faulting to the north, and is not found farther south of the map area. Davis (1984) found no similar rock in the central Highland Range. Intermediate lavas from the Nelson SW quadrangle (Faulds et al., 2002b) recognized as Thl (lower intermediate sequences, Volcanics of the Highland Range) have a similar composition to Thd, and are in roughly the same stratigraphic position.

The most voluminous unit (Thb) in the northern Highland Range extends into the southern and central Highland Range where it was first described by Davis (1984). Davis (1984) defined 14 volcanogenic and volcaniclastic sequences of lavas, lahars, and breccias and two units of lithic tuff beneath the Tuff of Bridge Spring and above the Precambrian gneiss as the "Highland Volcanics."

Three of the lava and breccia sequences of the "Highland Volcanics" were correlated by Davis (1984) to the Patsy Mine Volcanics (Anderson, 1971) based on morphology and regional stratigraphic relationships. However, trachyandesites in the 
northern Highland Range differ from the Patsy Mine Volcanics in that they lack olivine and typically have a gray to dark pink matrix compared to the dark brown matrix of the Pasty Mine Volcanics. Additionally, the Patsy Mine flows are extensive (up to $5 \mathrm{~km}$ ), whereas the lava flows of the northern Highland Range are rarely continuous for more than tens to a few hundred meters. Based on detailed mapping in this study, there is no clear rationale for dividing this sequence into numerous units as defined by Davis (1984). As well, there is no obvious set of distinctive criteria that can be used to correlate a portion of the sequence to the Patsy Mine Volcanics of Anderson (1971).

Faulds et al. (1999; 2002b) later defined unit Thb as the Volcanics of the Highland Range, which was described as a relatively monotonous sequence of trachybasaltic andesite lavas that thickened appreciably from the southern to the central Highland Range. The thick (>3,000 m) trachyandesite section of the northern Highland Range is dominated by discontinuous 3- to 12 m-thick lava flows with ubiquitous autobreccia-separating flows. Unit Thb from the northern Highland Range differs from Thb as described by Faulds et al. (2002a) in three distinct ways: (1) as much as 30 percent of the observed exposures of Thb comprise roughly equal volumes of lava and autobreccia as opposed to mostly lava flows and minor autobreccia; (2) local zones of clastic dikes and lava-sandstone breccia indicate that the lavas periodically interacted with water, but such features are absent farther south; (3) and the thick packets of volcanic breccias, lithic tuffs and lahars/debris flows (unit Tvb) interfingers with lavas of Thb in the central and northern Highland Range, but is absent to the south. 
Unit Tvb, in particular, is especially distinctive and is mostly absent from central Highland Range and not present at all in the southern Highland Range. Local lenses of volcanic breccia (Tvb) taper and die out within lava flows and autobreccia in the western exposures of Thb, which lie closer to the axis of the anticline (Fig. 34).

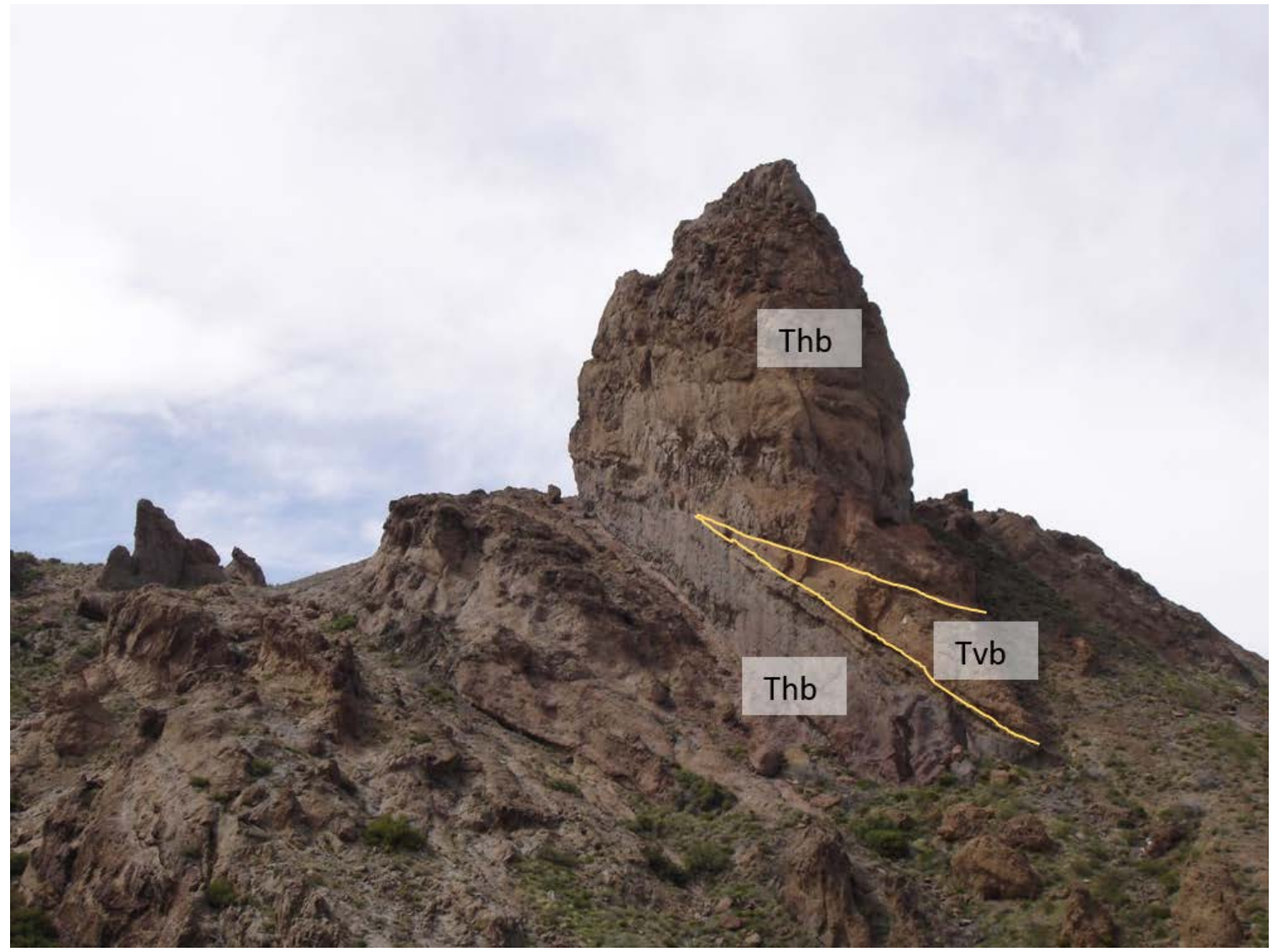

Figure 34. Interactions of lava flows and volcanic breccia. Orange volcanic breccia (Tvb) tapers to nothing between purple and orange trachyandesite lavas and autobreccias (Thb). Prominent summit block in center of view is approximately $25 \mathrm{~m}$ tall. View is to the west.

Similarly, Davis 1984) and the present study observed this unit thinning toward the south such that it is completely absent in the stratigraphy $1 \mathrm{~km}$ north of the anticline axis (Fig. 2). The tapering of this unit to the west and south, the intense propylitic alteration, the size to the largest clasts ( $>4 \mathrm{~m})$, and the presence of local thinly laminated 
tuffaceous siltstones and coarser sandy lenses suggest deposition close to a volcanic source and also within a basin that contained appreciable water.

Thin section and hand sample analysis of Tvb reveals many andesite and dacite clasts within a matrix of broken pyroxene crystals, a few relict glass shards, highly weathered and altered feldspar microlites, and secondary chlorite and sericite. The lack of abundant glass shards in the matrix could be from a small amount of transportation and winnowing of shards, as well as the intense propylitic alteration. The thinning and disappearance of this unit to the south suggests a source either in the central to northern part of the northern Highland Range, where Tvb is thickest, or outside the field area.

Field observation revealed three locations where steep-walled, thick (10 to $15 \mathrm{~m}$ ), intensely flow-folded dacitic lava domes predominantly reside within the lithic tuff. These domes also coincide with the thickest accumulation of Tvb, and Tvb here contains abundant large lithic clasts. The domes are located around the latitude of $3949000 \mathrm{~m} \mathrm{~N}$ in the central part of the map area (Plate 1). These are inferred to be possible vent sources (perhaps a vent complex within a small stratovolcano) for unit Tvb and are indicated by the three asterisks on Plate 1 near the latitude $3944000 \mathrm{~m} \mathrm{~N}$.

From tens of meters away, the domes initially look like thick trachyandesite lava flows due to color and morphology, but on closer inspection are revealed as domes of highly folded trachytic/trachydacitic lava within distinctly lighter-colored volcanic breccia of unit Tvb (Figs. 35a). The mineralogy of the domes, matrix, and clasts within the volcanic breccia are similar, and abundances of plagioclase and pyroxene; 20 to 30 percent, and 5 to 15 percent, respectively, are all similar. Amphibole and biotite are 


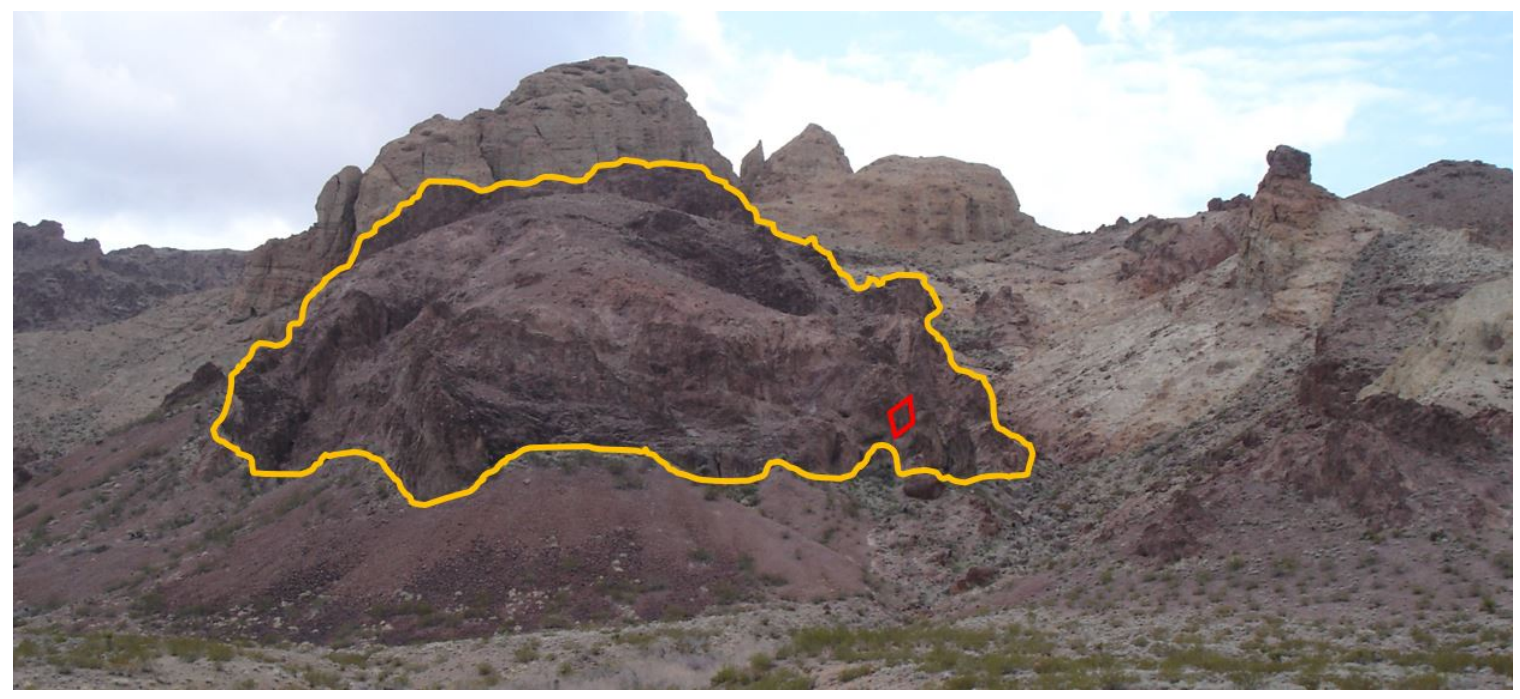

Figure 35A. Red trachyte dome (highlighted yellow; Thb) within the tan volcanic breccia (Tvb). Red pinnacle on the summit in the upper right of photo is capped by a trachyandesite flow (Thb).

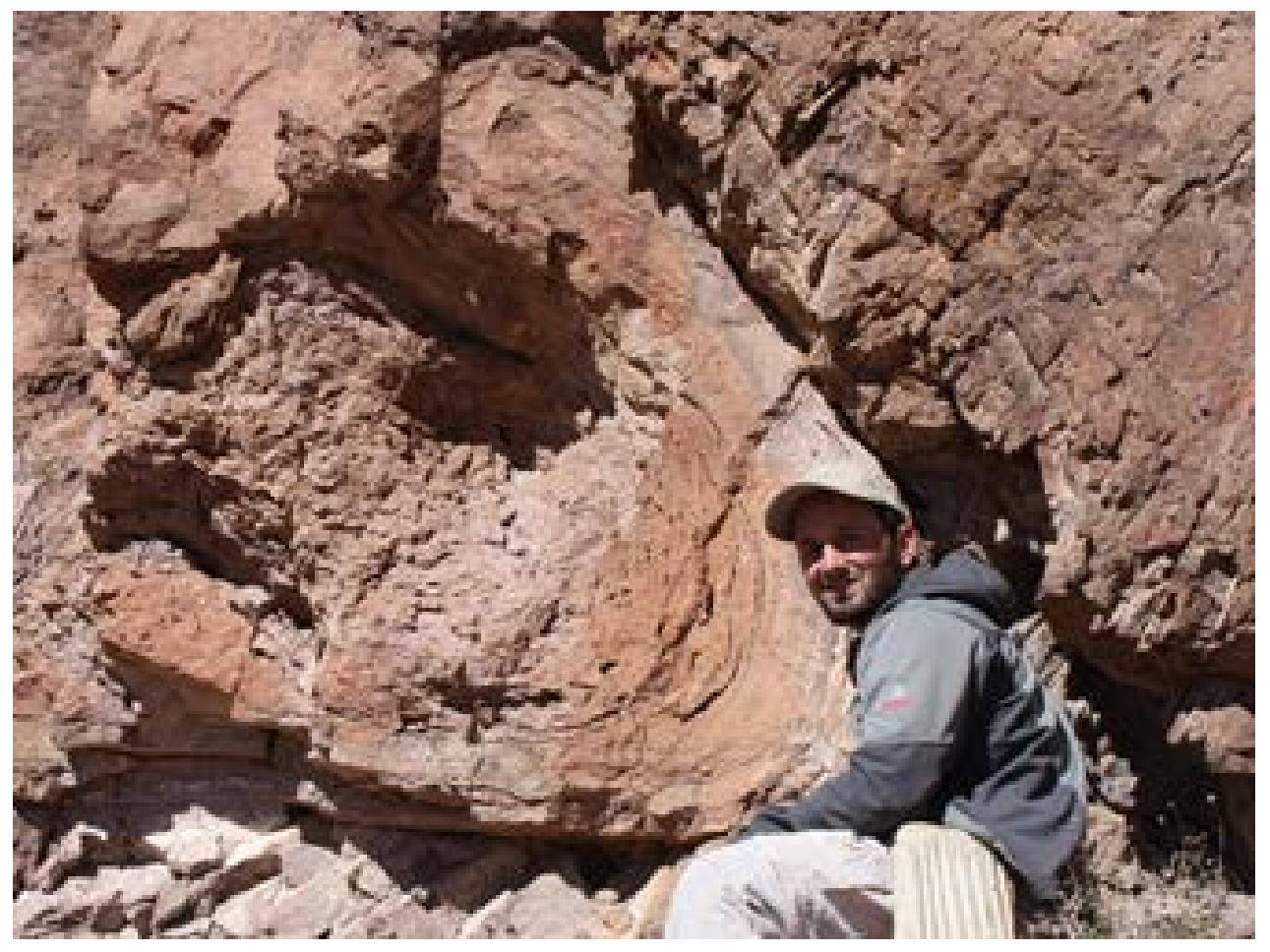

Figure 35B. Fold at the base of a trachyte dome. View of photo taken at red rhombus in (Fig. 35a).

Figure 35A and 35A. Trachyte domes within Tvb. 
present in minor to trace abundances. At the edge of one dome, volcanic breccia and lavas are interpreted as vent facies. Lenses of stretched, folded, flattened, and broken lava interfinger with volcanic breccia and similar fragments of lava, as blocks are entrained within the crystal rich matrix (Fig. 36). Orientations of flow banding range from generally sub-horizontal to vertical and displaying overturned folding (Fig. 35b).

Based on the observed physical relationships and petrology of the volcanic breccia and lava domes, Tvb is inferred to originate from this complex of domes. This correlation could be further tested by geochemical analysis of the domes and comparison with Tvb; the domes were not analyzed in the present study. Numerous trachyandesite and trachydacite dikes (Thbi) that mostly intrude through the voluminous units of the basaltic trachyandesite and trachyandesite lavas (Thb) and breccias (Tvb), and locally appear to feed some of the Thb sequence, are similar to dikes and intrusives recognized by earlier workers (Faulds et al., 2002a; 2002b; Davis, 1984), who also argued that the intermediate dikes represent the source pathways for the thick sequences of discontinuous trachyandesites of Thb (Fig. 33). The dikes do not cut the Tuff of Bridge Spring in any of the northern Highland Range exposures examined in this study, nor are they reported as cutting the Tuff of Bridge Spring in Faulds et al. (2002a) and Davis (1984).

Other than the regionally recognized Tuff of Bridge Spring, the stratigraphy in the northern Highland Range is poorly dated. The regionally extensive Peach Spring Tuff (18.8 Ma) (Ferguson et al., 2013) defines the base of Miocene volcanic strata in the southern Highland Range and northern Eldorado Mountains, but is only a few meters 


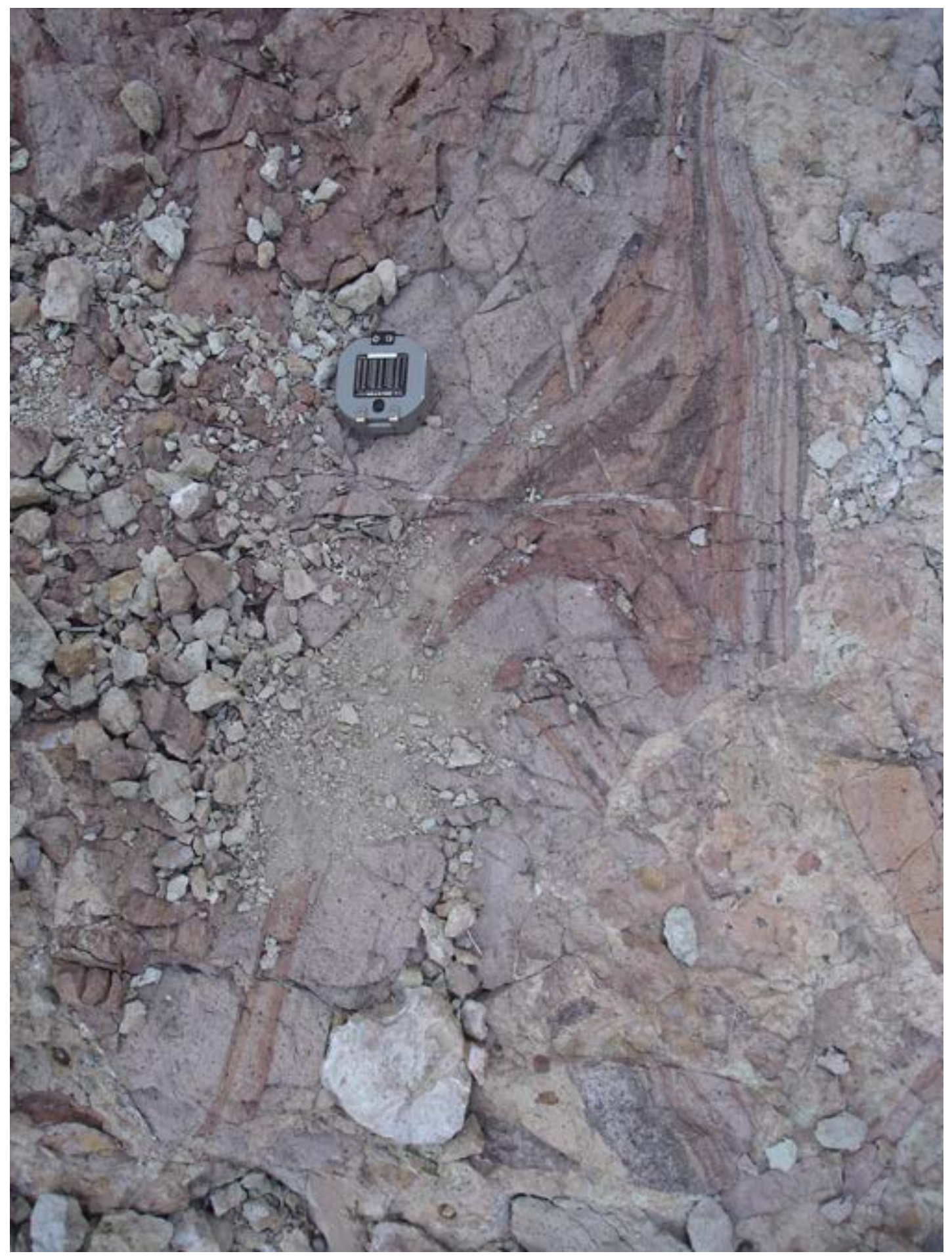

Figure 36. Deformed trachyte lavas within volcanic breccia. Stretched, banded, and brecciated trachydacitc flows intermingling with lithic tuff (Tvb). Compass for scale. 
thick in these areas and is absent farther to the north (central and northern Highland Range). An intermediate trachydacitic-trachyandesitic volcanic sequence (Volcanics of the Dixie Queen Mine) overlies the Peach Spring Tuff in the southern part of the Highland Range (Faulds et al., 2002a; Varga et al., 2004). The trachydacite lavas in this sequence have been dated at 18.5 to $16.3 \mathrm{Ma}$ (Faulds et al., 1995). Rhyolite lavas and tuffaceous rocks located in the southern Highland Range are 16.26 to 16.21 Ma and capped by the basaltic trachyandesite and trachyandesite lavas of the Highland Range (Thb of Faulds et al. 2002a; 2004) that extend from the south and comprise the majority of volcanic stratigraphy in the map area. Ages for these lavas obtained by Faulds et al. (2002a) span from 15.98 Ma to 15.66 Ma in the south to 18.27 Ma, where they lay unconformably on Precambrian orthogneiss, to 16.03 Ma in the central Highland Range, where the sample was obtained from a flow beneath the Tuff of Bridge Spring (Fig. 37). These age data suggest that the strata in the northern Highland Range comprising unit Thb are time transgressive to the lower southern Highland Range volcanic units ( $\mathrm{Tq}$ and Thr) (Fig. 38). The accumulation of a thick sequence of volcanic and volcaniclastic strata in the northern Highland Range and specifically the thinning of volcaniclastic units in the central Highland Range is compatible with the suggestion of Faulds et al. (2002a) that the hinge zone likely constituted a structural high during eruption and deposition of the units (Fig. 2). Figure 38 is a schematic north-south cross-section interpreting the general stratigraphic and volcanic facies relationships in the Highland Range as summarized above and using published absolute age constraints from Faulds et al. (2002a; 2004). 


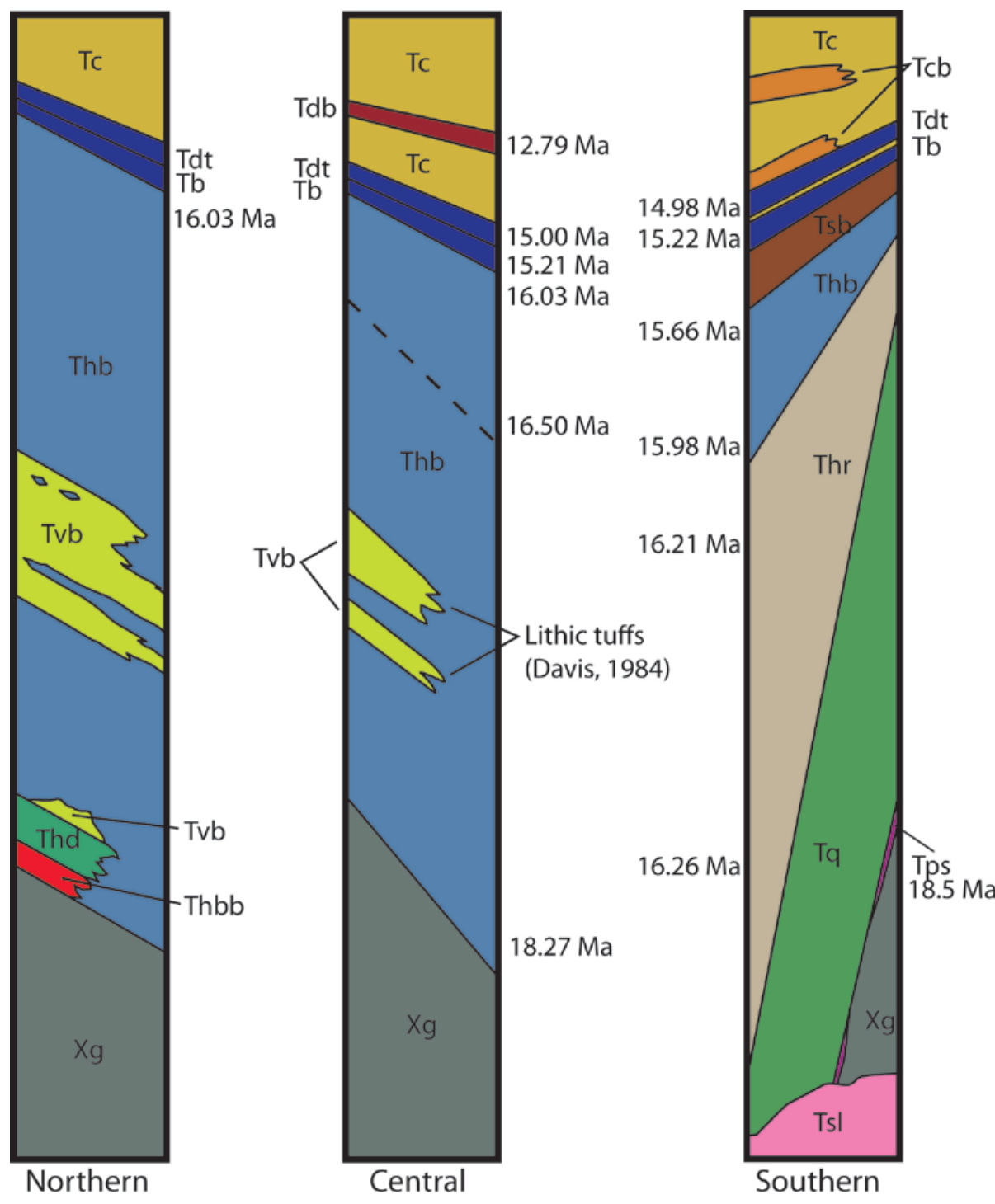

Figure 37. Stratigraphic column of the northern, central, and southern Highland Range. Figure modified from Faulds et al. (2002a). Unit descriptions described in Fig. 2. Columns represent approximately $5000 \mathrm{~m}$ of strata.

The closest volcanic sequences to the northern Highland Range are found in the central and southern McCullough Range, approximately $10 \mathrm{~km}$ to the northwest. Within the age range of 18.5 Ma (Peach Spring Tuff) and 15.22 ma (Tuff of Bridge Spring) are volcanic and volcaniclastic sequences that resemble the strata of the northern Highland 
Range and may partially correlate with the northern Highland Range area. This correlation awaits more detailed examination.

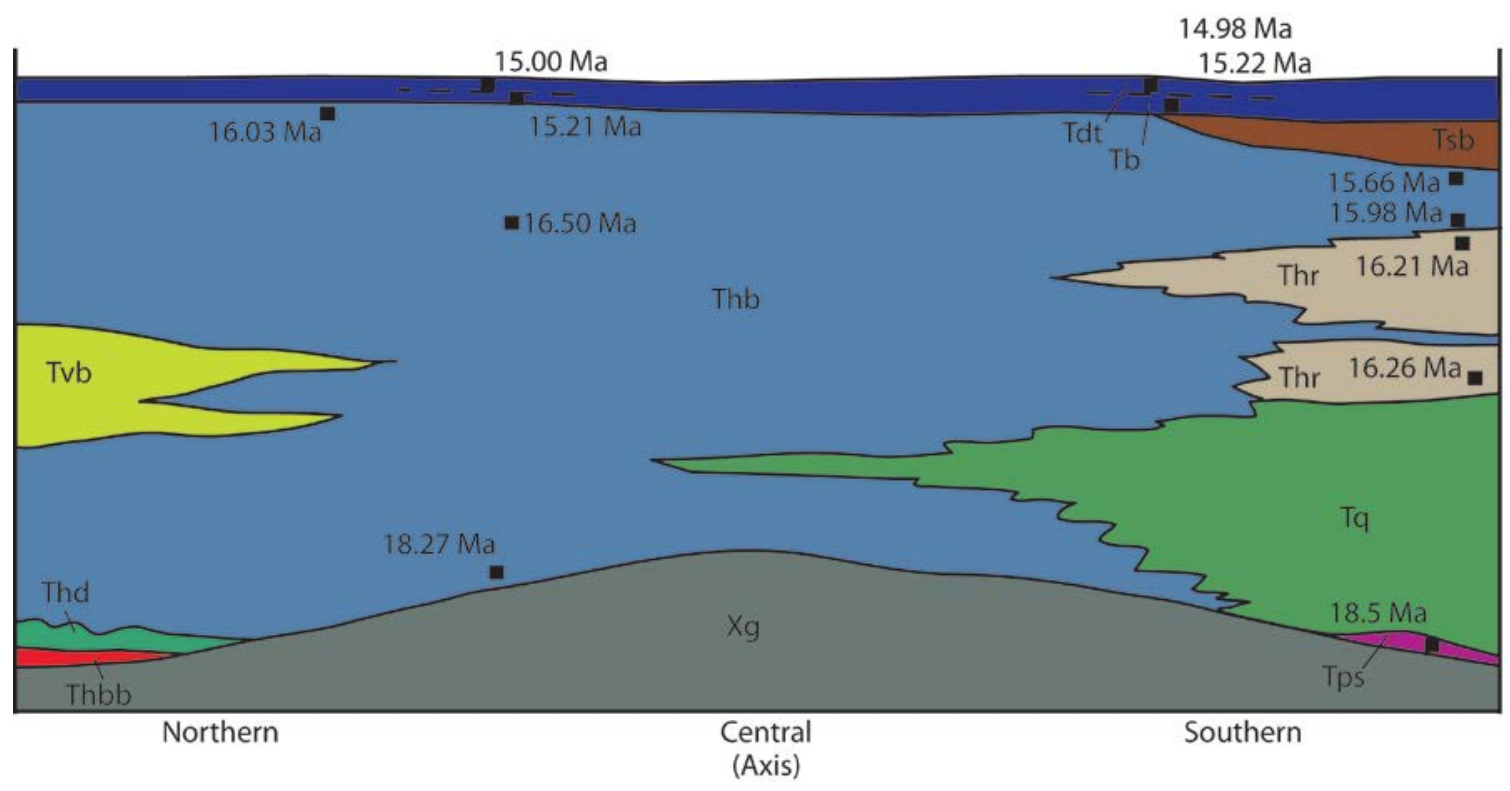

Figure 38. Cartoon cross section of the northern, central, and southern Highland Range. Drawing modified from Faulds et al. (2002a).

\section{Petrologic Comparisons to Highland Range Rocks and Surrounding Areas}

Volcanic samples collected from the central and southern Highland Range (Faulds et al., 2002a; Colombini et al., 2011; Johnson, 2014) and McCullough Range (Smith, 2010) were plotted with 10 selected samples from the study area (Fig. 39). Oxide, major, and minor geochemical data are tabulated and attached in Appendix B: Tables A through E. As noted previously, nine of the northern Highland Range volcanic rocks plot within a field of trachyandesites and trachydacites. One sample collected from the matrix of the volcanic breccia (HR229A in Figure 21 (yellow circle) and in Figure 39 (yellow square)) 


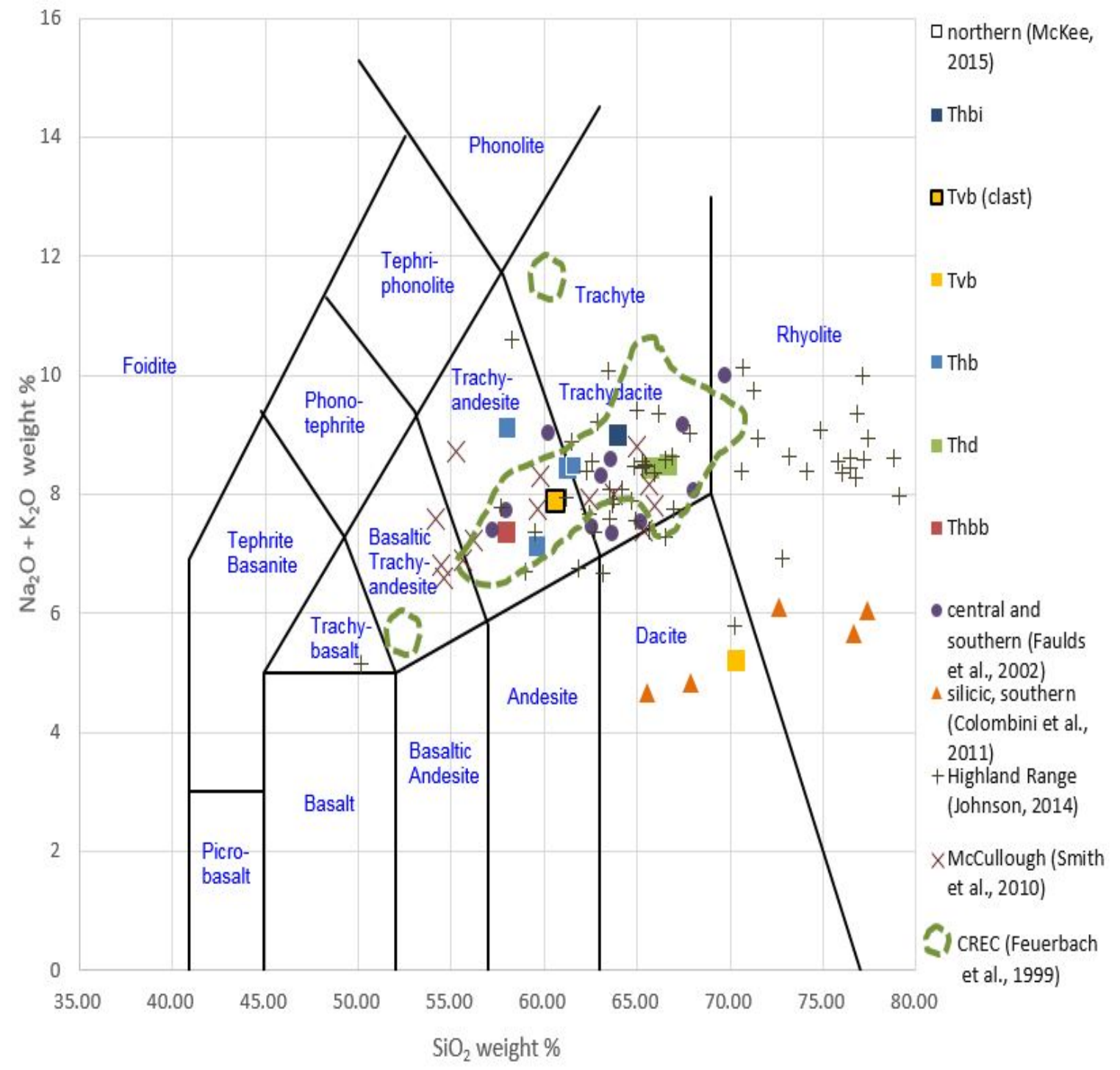

Figure 39. TAS plot of samples from the northern Highland Range and regionally adjacent volcanic rocks. Northern Highland Range: squares; (Thbb) red, (Thd) green, (Thb) light blue, (Tvb) yellow [outlined, clast within matrix], (Thbi) dark blue. Central and southern Highland Range (Faulds et al., 2002a): purple circles. Silicic volcanic rocks from the southern Highland Range (Colombini et al., 2011): orange triangles. Highland Range volcanic units (Johnson, 2014): crosses. McCullough Range volcanic units (Smith et al., 2010): X. Stage 2 trachyandesites and trachydacites of the Colorado River extensional corridor (Feuerbach et al., 1999): samples fall within dashed line. 
plots as a dacite within a group of dacites and rhyolites collected from the southern Highland Range. However, this sample may have experienced K loss due to propylitic alteration (Appendix A: HR229A) and is more likely a trachydacite in composition. Trachyandesite and trachydacite volcanic rocks of the northern Highland Range plot within a similar field as "stage 2" trachyandesites (solid diamonds) and trachydacites (*) of Feuerbach et al. (1999). Feuerbach et al. (1999) inferred that the monotonous and geochemically similar sequence of lavas were produced from mid- to upper-crustal steady-state magmatism during periods of extension within the Black Mountains accommodation zone.

Select minor and trace elements from the northern Highland Range, normalized to chondrite concentrations, were compared to central and southern Highland Range rocks (Fig. 40). All samples exhibit a similar pattern of relative enrichment and depletion. The trachyadesites and trachydacites from all areas have similar chondrite-normalized concentrations. The greatest variation is observed in some incompatible element concentrations for silicic samples (rhyolites and rhyolitic tuffs) from the southern Highland Range (Johnson, 2014) (Fig. 41). Patterns for intermediate rocks from the neighboring McCullough Range (Plate 1) are broadly similar to those in the study area, but encompass a somewhat wider range of chondrite-normalized values.

Chondrite-normalized REE plots from the intermediate rocks from the northern, central and southern Highland Range (Faulds et al., 2002a) and felsic rocks of the "silicic volcanic sequence” of the southern Highland Range (Colombini et al., 2011) have strong LREE enrichment and modest negative Eu anomalies (Fig. 42). 


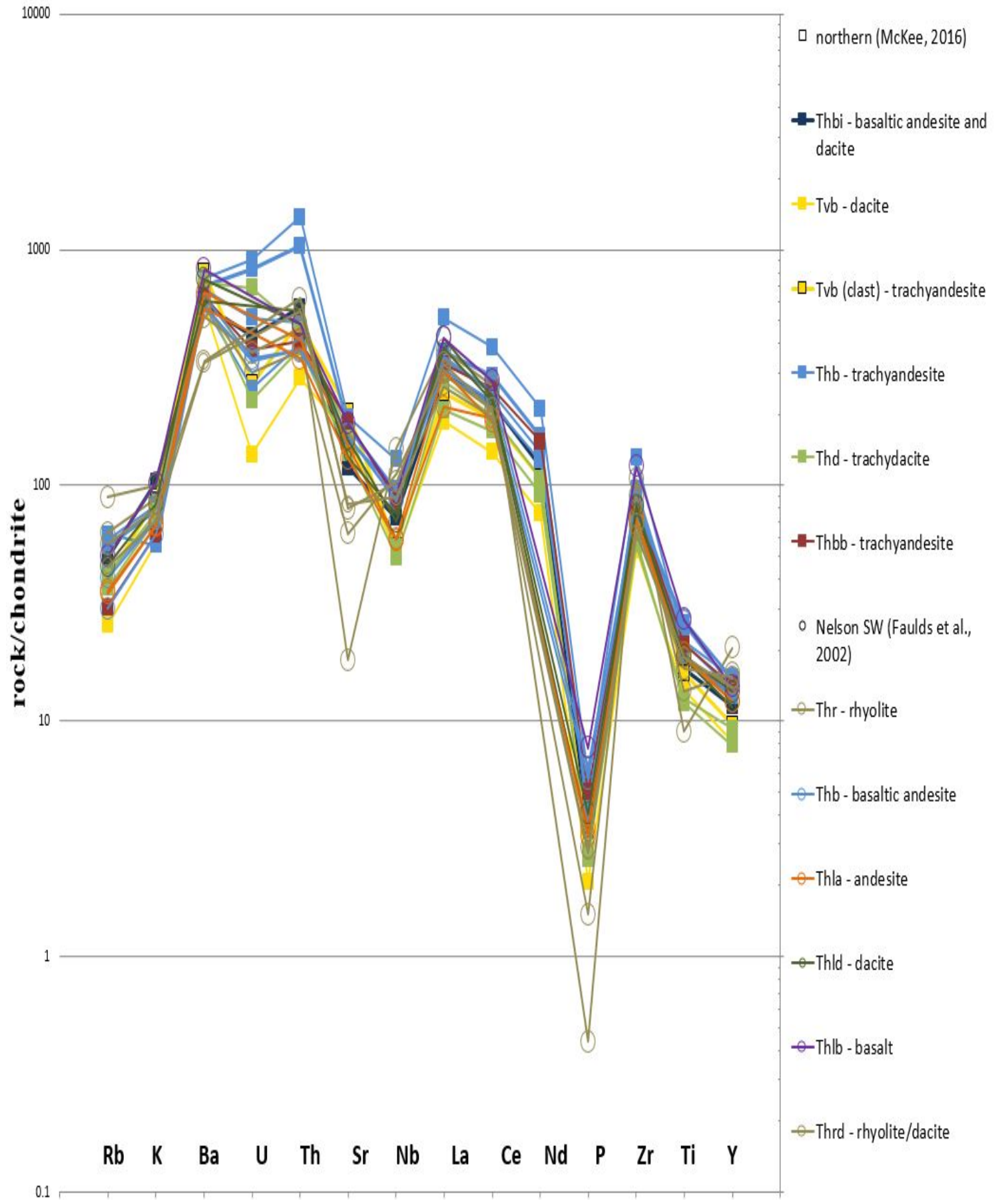

Figure 40. Trace elements of the northern Highland Range and Nelson SW Quadrangle. Northern Highland Range (squares), Nelson SW Quadrangle samples (circles). 


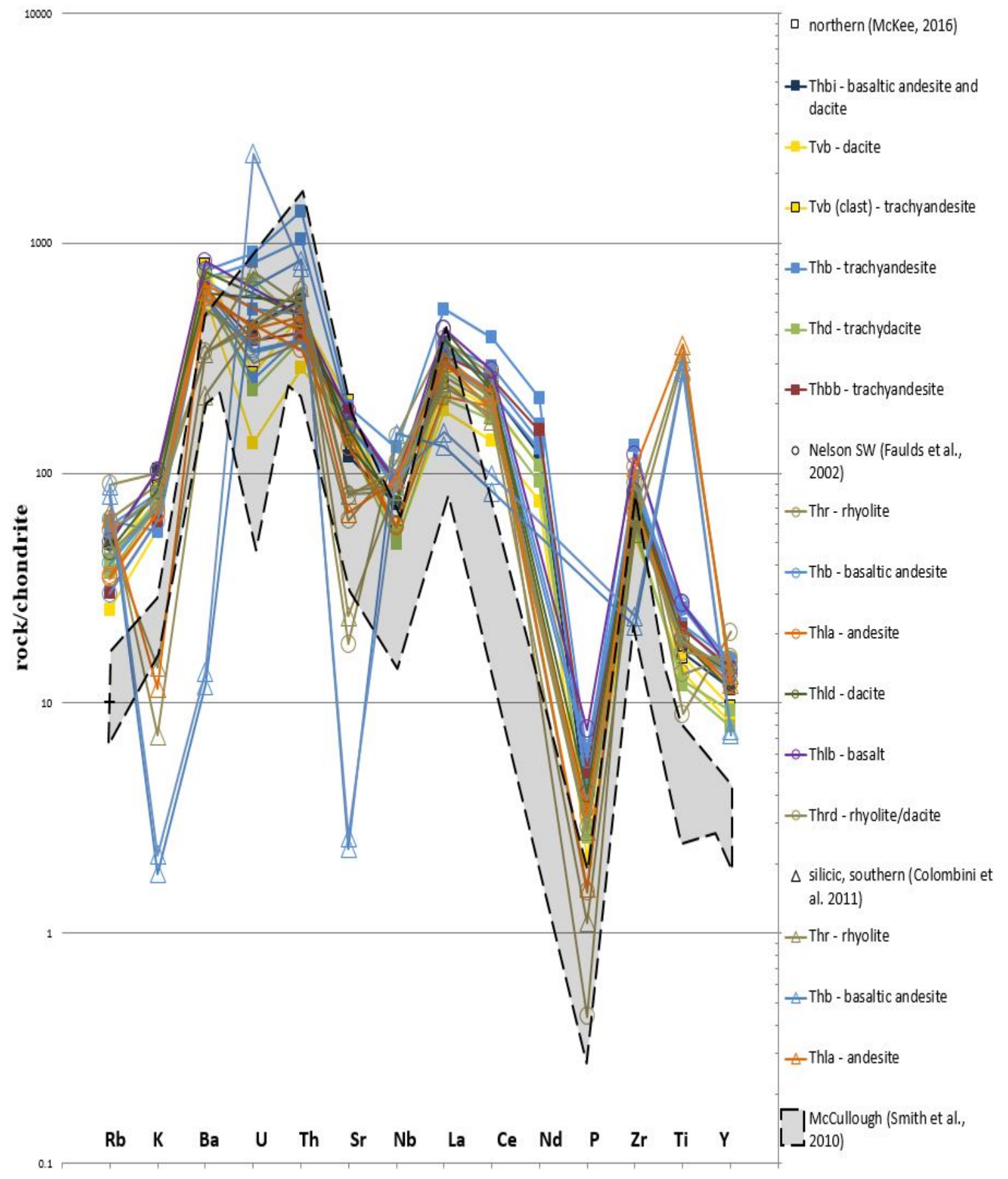

Figure 41. Trace elements of the northern Highland Range and surrounding local units. Northern Highland Range samples (squares), Nelson SW Quadrangle (central and southern) samples (circles), silicic southern units of the Highland Range (triangles), and McCullough Range (dashed gray field). 


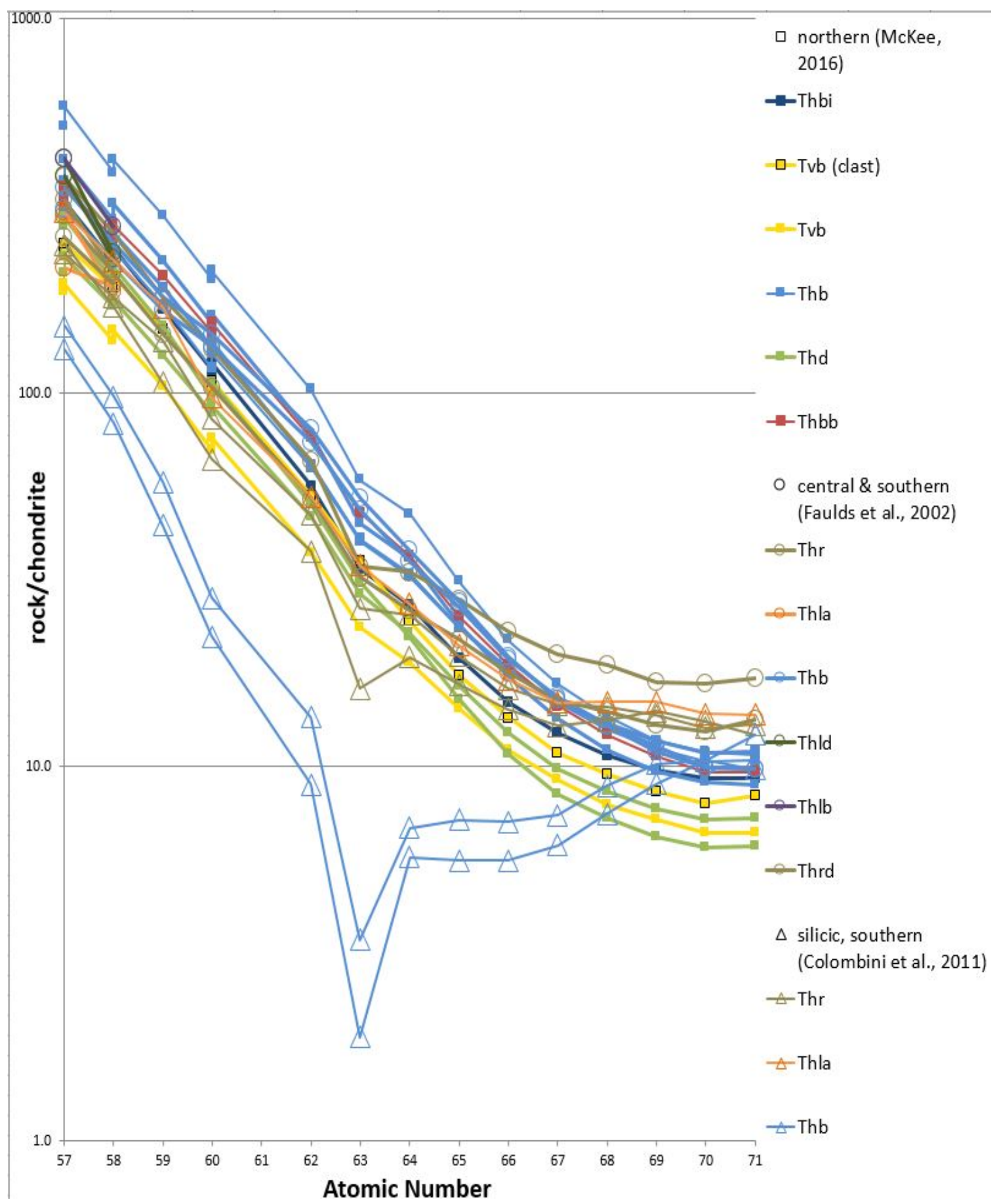

Figure 42. REE of the northern Highland Range and surrounding local areas. Northern Highland Range (squares), central and southern Highland Range (circles), and silicic southern units (triangles) from the Highland Range. 
The LREE-enriched signatures are common in mafic and intermediate rocks of the Colorado River extensional corridor and are inferred to represent involvement of geochemically enriched (in LREE's and LIL's), lithospheric mantle in the sources of the lavas (e.g. Bradshaw et al., 1993; Miller et al., 2000; Feuerbach et al., 2001; Metcalf, 2004). The more felsic samples from the central and southern Highland Range display distinctly different patterns that likely reflect strong accessory mineral control, especially titanite (Colombini et al., 2011). Unit Tvb, which is the most silicic unit analyzed in the present study, shows lower chondrite-normalized concentrations than all other more mafic samples from the northern Highland Range, but the overall pattern does not resemble the silicic rocks from the southern Highland Range.

\section{Structure}

\section{Faulting}

Faults were organized into three zones based predominantly on strike. Each zone was subdivided into major and minor faults. Major faults generally cut other faults and extend longer than minor faults, which are generally short and at oblique angles to major faults. Zone 1 major faults are north-striking and predominantly west-dipping. Zone 2 major faults strike to the northwest, generally dip southwest, and align sub-parallel to the axis of the anticline that defines the axial trace of the Black Mountains accommodation zone (Fig. 2). Zones 1 and 2 major faults fit the definition of Lake Mead domain: west-dipping normal faults in east-tilted fault blocks north of the Black Mountain accommodation zone (Faulds et al., 2001) (Fig. 43). Zone 3 major faults are north- to northeast-striking and dip to the southeast or northwest. Zone 3 minor faults display the 
most erratic orientations in the map and are predominantly bound between the two horstforming oppositely northeast-striking faults. Zone 3 faults do not fit within the definition of the Lake Mead domain.

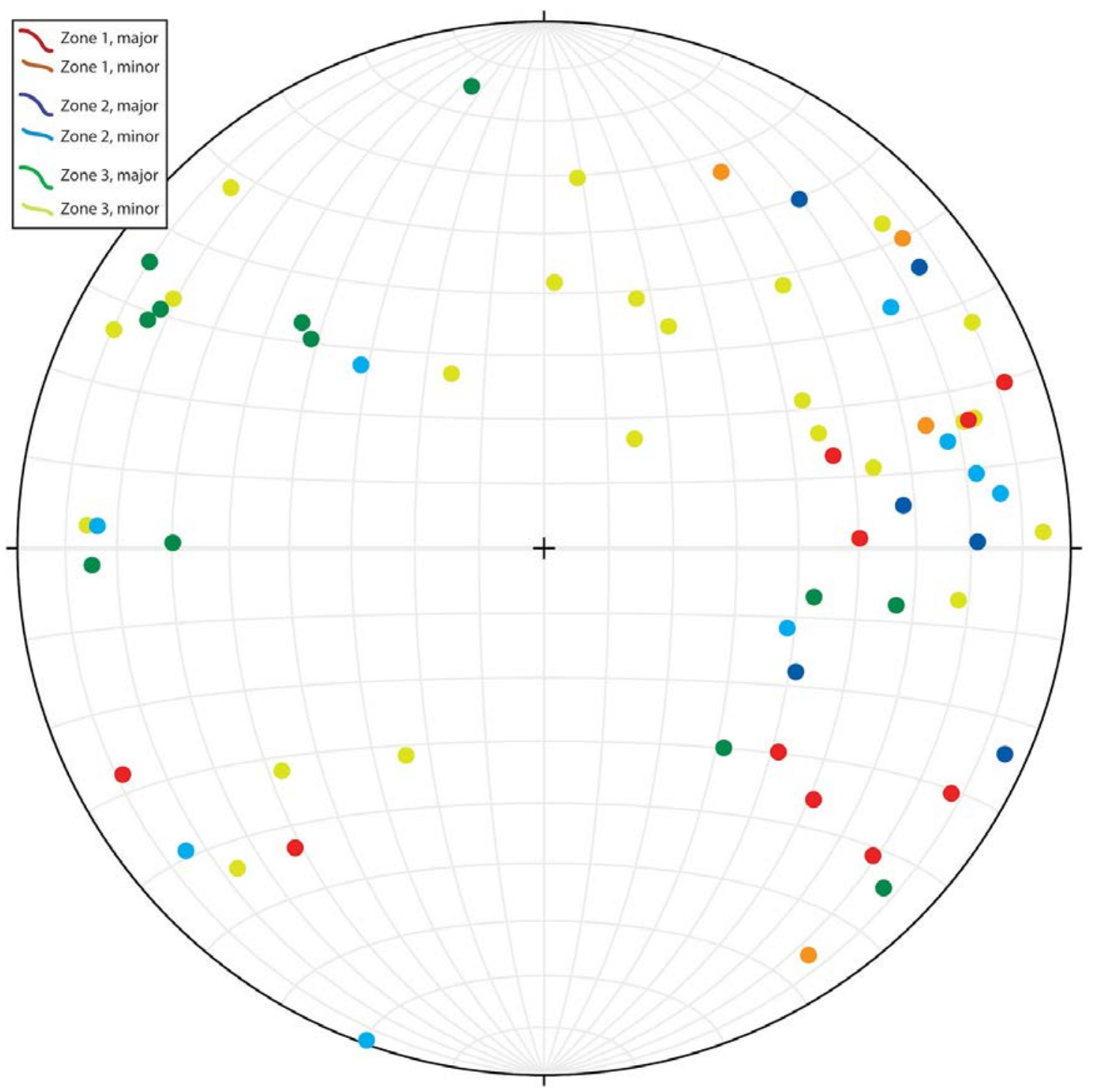

Figure 43. Stereonet of faults in relation to zone. Colors of poles to plane correspond to different fault zones in Figure 27. 


\section{Tilting and Extension}

Lava flows, volcanic breccias, tuffaceous sandstones, lahars, and debris flows are overwhelmingly east-tilted, occurring along west-dipping faults. All units lie sub-parallel to each other, and no obvious or distinct change in dip is observed at range scale or when

plotted on stereonets (Fig. 29). The thick sequence of poorly to massive-bedded volcanic breccias and debris flows (Tvb) in the northern Highland Range separates a mineralogically and morphologically uniform series of lavas and autobreccias (Thb). With the middle of the local volcanic section defined within the tan, green, and yellow volcanic breccia (Tvb), average strike and dip of beds in the upper half strike is $348^{\circ}$ and dip $27^{\circ}$ to the east. In comparison, beds in the lower half, strike is $351^{\circ}$ and dip $29^{\circ}$ to the east. Average strike and dip is based on the mean vector of the poles to the planes. The indistinguishable dips in bedding above and below the Tvb show that no significant extension occurred during the deposition of more than 3,000 m of lavas and pyroclastics (Fig. 30).

Despite the observed uniformity of average dip, dips in individual outcrops vary from approximately $25^{\circ}$ to $45^{\circ}$ (Fig. 29). Variation in bedding dip was observed throughout the entire section as the progressive deposition of non-planar lava flows and autobreccias produced irregular topography for the successive volcanic event. Lavas with autobreccia make up the vast majority of rock, leaving trace exposure of volcaniclastic sedimentary units to obtain bedding angles; the majority of beds were found within the sequences of volcanic breccia. Dip angles were predominantly measured from the base of lava flows where contact with the basal autobreccia was 
generally planar. Lengths of lava flows are diverse. Packets of shorter flows from 5 to 10 meters in length are non-planar as they have filled between, around, and on other flows and breccias. Other sections consist of usually thicker flows continuing for hundreds of meters. Significant changes in dips near faults were not recognized in the field. All of these factors contribute to scatter in the data, but it is worth noting that not only are the average dips remarkably similar, but the overall dispersion of dips (and strike orientations) is similar above and below the volcanic breccia unit (Tvb).

Systematic variation in tilting magnitude is observed between the southern and central Highland Range, with central Highland Range strata tilted less steeply than southern Highland Range strata, which are tilted up to $90^{\circ}$ and even locally overturned (Faulds et al., 2002a). Additionally, younger strata in the southern Highland Range are progressively less steeply tilted than older strata and exhibit tilt fanning (Fig 37). Faulds et al. (2002a) attribute this to initiation of extension after deposition of early intermediate volcanic strata, but with extension overlapping with deposition of younger felsic and mafic/intermediate volcanism; tilt-fanning is attributed to rotation on listric normal faults in a growth-fault type relationship. Tilt magnitude within the northern Highland Range is lower than that observed for most of the strata in the southern Highland Range, although overlapping that observed in the central Highland Range (Fig. 37).

Based on the existing age relationships discussed above, the volcanic rocks in the northern Highland Range were erupted between 18.27 Ma (Tha, and equivalent to Thb) and 15.21 Ma (Faulds et al., 2002a), with no obvious disconformities that might suggest a significant time break. This time range overlaps that inferred for volcanism in well-dated 
volcanic strata in the southern Highland Range (Fig. 38). The only obvious angular discordance is located in the southeast corner of the map area, where average dips of the Tuff of Bridge Spring (Tb) and Tuff of Mount Davis (Tdt) $\left(19^{\circ}\right)$ differ from those of the underlying trachyandesite by approximately $15^{\circ}$; this is displayed in cross section B-B' (Plate 2). Over the majority of the map area, the Tuff of Mount Davis and Tuff of Bridge Spring have an average dip of $27^{\circ}$. Underlying east-dipping trachyandesite strata have an average dip of $28^{\circ}$; therefore, tuff bedding attitudes are similar to all underlying strata. Thus, a first order inference based on the variation from south to north in tilt magnitude (Fig. 37) is that the northern Highland Range experienced less total extension than the southern Highland Range. Furthermore, the generally uniform tilting observed throughout the northern Highland Range indicates that the majority of volcanism predated the onset of extension. The $15^{\circ}$ variation in dip observed between the Tuff of Mount Davis and Tuff of Bridge Spring in the southeast corner of the map area may be due to the variation in timing and the possible duration of extension from south to north. The dips of faults and fault-bedding angles provide some information on the style of faulting and how extension was accommodated. Fault dips are variable but average ca. $60^{\circ}$ for both east and west-dipping faults (Figs. 25 and 26). Fault-bedding angles are variable but generally large $\left(\geq 60^{\circ}\right)$ and not uncommonly near $90^{\circ}$ (Plate 2), indicating also that faults initiated at fairly steep angles to the originally horizontal to subhorizontal lava flows and volcaniclastic members. These two relationships would be consistent with extension occurring by slip on sub-parallel, steeply dipping faults with relatively planar geometry, accompanied by or followed by uniform rotation of faults to their current 
orientations (i.e. domino-style fault blocks) (Plate 2) to tilt the strata. Listric geometry cannot be completely ruled out, and possibly faults may become curved at depth (listric) as inferred for the southern Highland Range.

A regional investigation by Gans and Bohrson (1998) found that magmatism in the northern part of the Colorado River extensional corridor, including areas at the same latitude as the northern Highland Range, ceased around the onset of extension-related tilting and unroofing. The relationships observed in the northern Highland Range, uniform tilting with no significant change in tilt up section, would be consistent with their regional observations and conclusions.

\section{Relationship of the Northern Highland Range to the Black Mountains Accommodation Zone and Lake Mead Extensional Domain}

Although the east-tilted strata of the northern Highland Range has been interpreted by Faulds et al. (2002a) as the northeastern limb of an extensional anticline within the Black Mountains accommodation zone, fault geometries between the northern and central Highland Range differ. Planar west-dipping faults in the north dominate in comparison to the listric east- and west-dipping faults of the central and especially southern Highland Range. Fewer east-dipping faults are expected as the map area is situated north of the accommodation zone and faulting is more consistent with Lake Mead domain faulting and tilting characteristics (Faulds et al., 2001; 2002a).

West-dipping faults in the Lake Mead domain are inferred to sole into a west-dipping, low angle detachment with a headwall expressed more than $70 \mathrm{~km}$ to the east by the Grand Wash fault (Fig. 1). Whether the northern Highland Range faults sole 
into a deeper part of the Grand Wash fault at depth is not clear, as the east-dipping headwall detachment surface to the Whipple Mountain domain, the McCullough Range fault, lies just $3 \mathrm{~km}$ to the west of the map area. Cross-sections were placed to encompass the McCullough Range fault to display possible interactions between faults from oppositely dipping domains. Because of the proximity of the McCullough Range fault to the map area, I infer that the mostly west-dipping faults in the northern Highland Range dip into and are antithetic to the McCullough Range fault. As discussed above, the magnitude of extension clearly dies out from south to north in the northern Highland Range, and it is uncertain how the west-dipping and east-dipping detachments interact at depth, or how and whether faults in the northern Highland Range sole to the east-dipping McCullough Range fault as shown on Plate 2.

The basement horst in the northern Highland Range (Plate 1) is shown on the west side of cross-section A-A' (Plate. 2) and may be indicative of this structural complexity. The horst is created by a series of oppositely-dipping faults that produced the largest amount of displacement in the map area. Displacement along the horstforming sets of faults increases moving north, placing volcanic breccia (Tvb) against basement orthogneiss (Xg) (Fig. 44; Plates 1 and 2). West-dipping faults to the east of the horst display lower amounts of slip and have more moderate dips in comparison to faults west of the horst. Volcanic strata on the horst strike to the northwest in comparison to the predominantly north striking strata observed in the rest of the map area. Displacement presumably dies outs on the McCullough Range fault moving to the north, and it is possible that the horst structure seen in the northern Highland Range 
represents part of a complex extensional fault zone with variable displacement being taken up on the McCullough Range fault and the horst-bounding faults (Fig. 44). The presence of a basement horst clearly shows that extensional deformation in this area is complex and that the overall structure and tilting observed are not easily interpreted within the context of oppositely dipping tilt domains, or necessarily as the east-dipping limb of an extensional anticline.

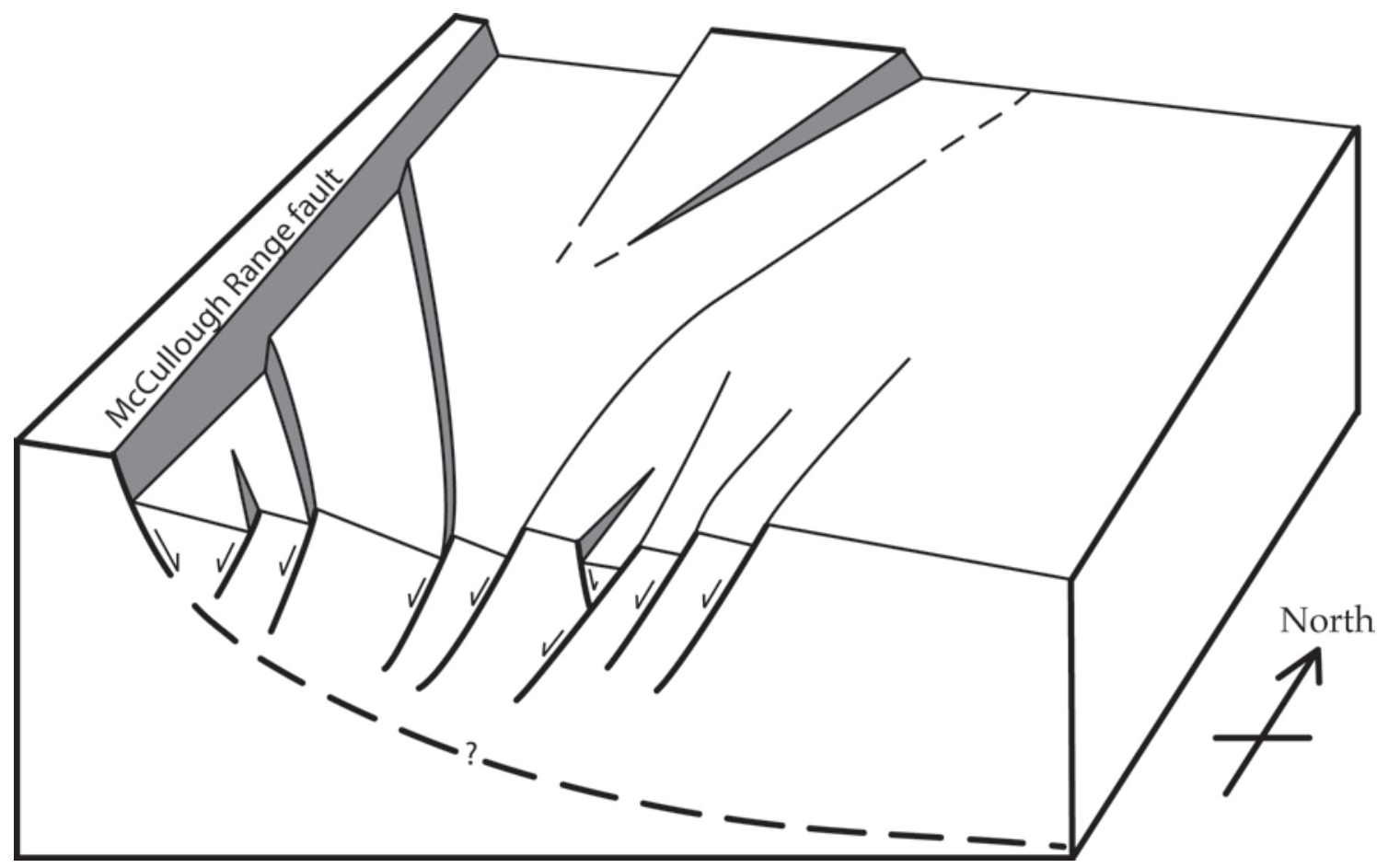

Figure 44. Schematic and simplified three-dimensional block diagram showing possible faulting relationships in the northern Highland Range. Note that in this diagram the extensional anticline in the central Black Mountains is not shown.

\section{Fault and Dike Interaction}

Although the data are scattered, dikes strikes are crudely similar to fault strikes (Fig. 45). Field relationships and structural data combined argue for a penecontemporaneous relationship between diking and faulting within the northern 
Highland Range (Fig. 46). Dikes in the northern Highland Range strike roughly north in the south, becoming more northeasterly moving northward, and ultimately have an easterly strike in the northern reaches of the map area (Fig. 47).

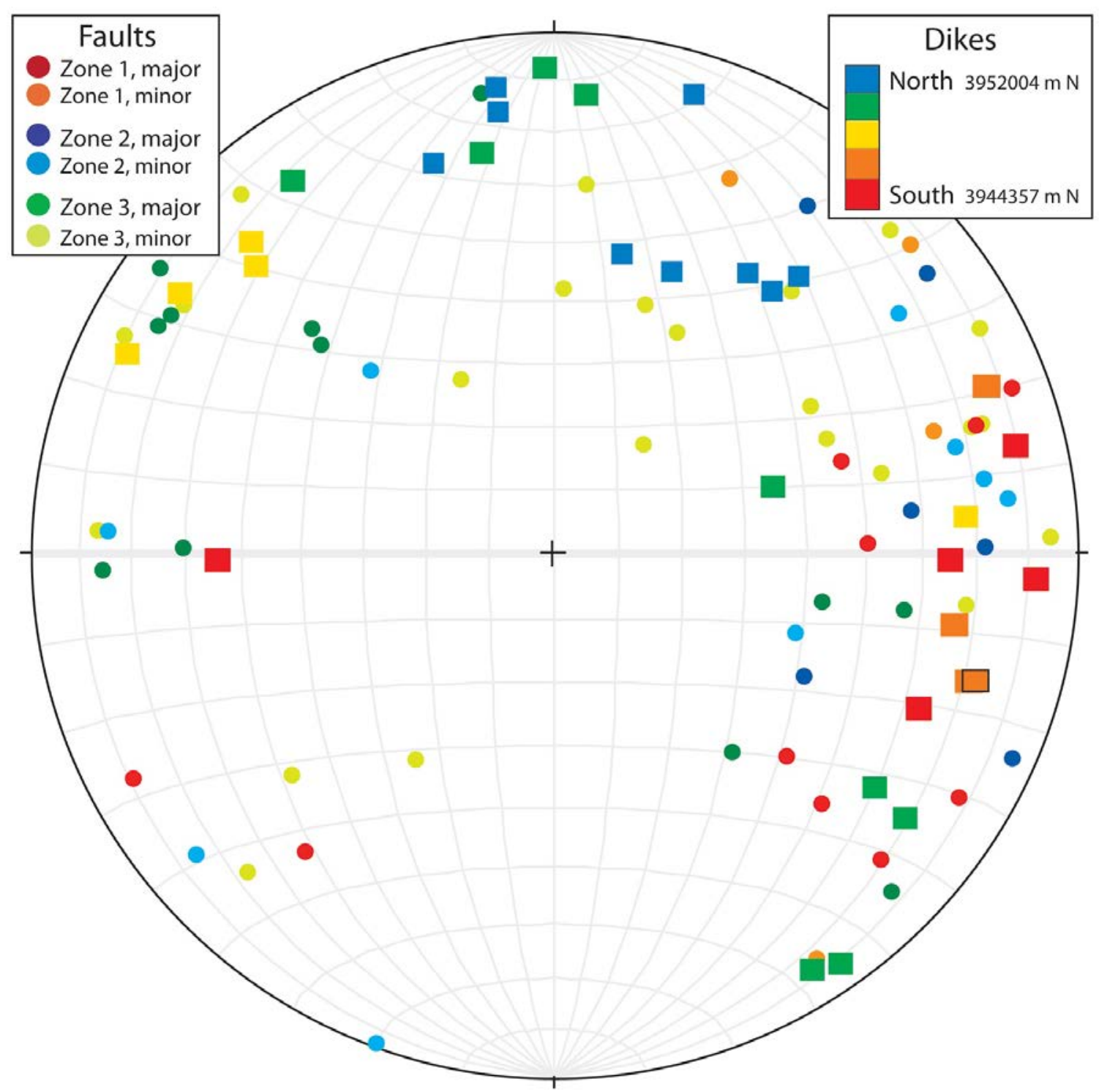

Figure 45. Fault and dike orientations of the northern Highland Range. 


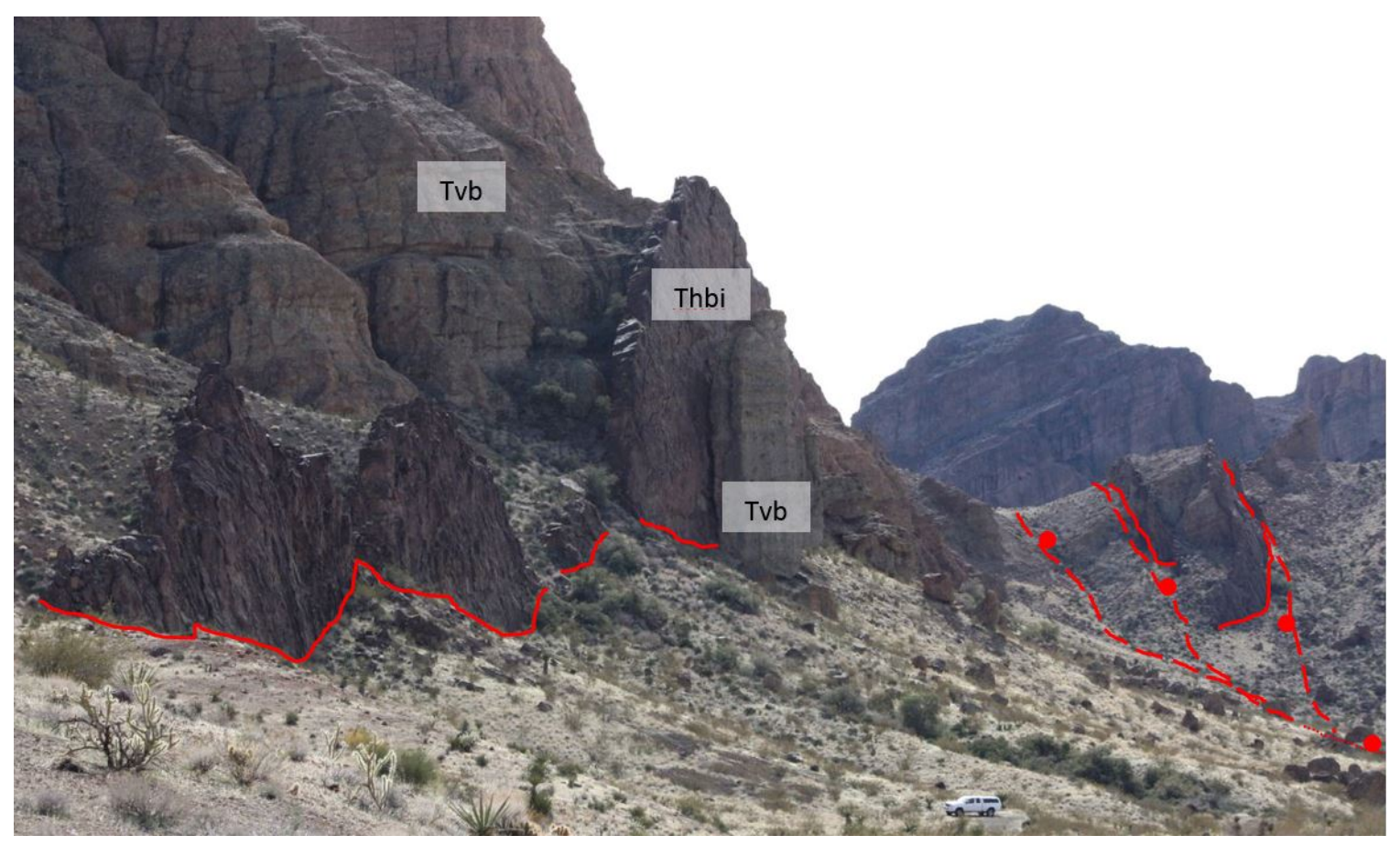

Figure 46. Major faults of zone 1 and associated dikes. Solid red lines highlight the base of dikes. Dashed red lines define zone 1 major faults. Dike in the left side of view has a strike of approximately $010^{\circ}$ (azimuth). Two dikes at pass on right side of view are subparallel to a series of faults that converge into a range-scale persistent, west-dipping fault. View is to the south. Note truck at bottom of photo for scale. Photo courtesy of Chris Scudder.

The faults in zones 1 and 2 also are dominated by north strikes, whereas faults in zone 3 strike more northeasterly to easterly. Similar dipping fault and dike dip angles are compatible. West-dipping dike and fault dips are $68^{\circ}$ and $58^{\circ}$, respectively. East-dipping dike and fault dips are $72^{\circ}$ and $60^{\circ}$, respectively. To illustrate this relationship, dike data for the map area were divided evenly into five groups latitudinally (between 3944357 m to $3952004 \mathrm{~m} \mathrm{~N}$ ) and assigned a color, and poles to dikes were plotted on a stereonet with the fault zones (Fig. 45). This plot makes two important points: (1) Dikes and normal faults record the same overall extensional strain field and are therefore roughly synchronous; (2) either the strain field was variable from north to south in the map area 


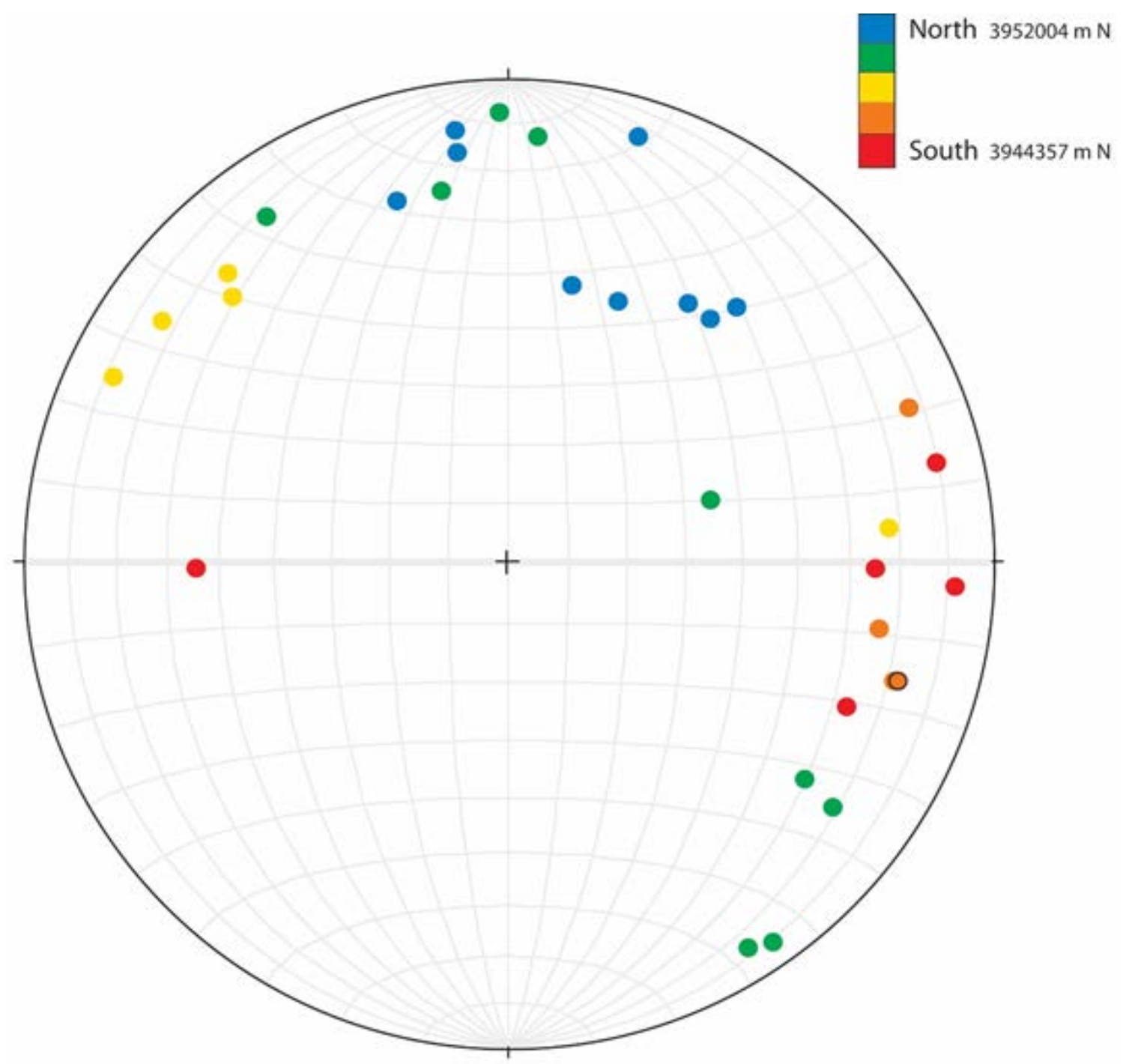

Figure 47. Stereonet of dike orientations. Poles to planes color coded according to latitude.

or dikes and faults in the northern area (fault zone 3) have experienced modest, but of unknown magnitude, clockwise, vertical-axis rotation. Regarding point (1), as with the fault orientations in zones 1 and 2, dike orientations in the same areas of the map are consistent with east-west extension. Regarding point (2), if dikes and faults record a spatially variable strain field, then this would suggest that extensional strain changed from roughly east-west to north-northwest-south-southeast. Such a significant shift in the 
strain field over a short distance seems unlikely. However, the inferred vent area mentioned earlier in the discussion also occurs roughly at the transition from north-south strikes to more northeast-southwest and even east-west dike strikes (Fig. 27 and Plate 1). If this represents the remnants of a stratovolcano, then it is also possible that a shallow magma chamber beneath the volcano could have locally interacted with the farfield tectonic stresses and reoriented the principal stress axes in the vicinity of the volcano. The alternative possibility mentioned in regard to point (2), that the northernmost Highland Range might have experienced modest vertical axis rotation that did not affect the rest of the map area, cannot be ruled out from the data presented here. Some modest vertical-axis rotation might also be compatible with the general view that the northern Highland Range represents a complex transition between highly extended areas farther to the east and the little extended area to the west-northwest.

\section{CONCLUSIONS}

The field relationships, geologic mapping, petrography, geochemistry, and structural analysis of the northern Highland Range lead to the following conclusions.

The northern Highland Range is a ca. 3,000 m-thick sequence of volcanic and volcaniclastic flows and breccias overlain by regionally extensive tuffs (Mt. Davis and Bridge Spring). The northern Highland Range has an intermediate-felsic-intermediate Miocene volcanic progression similar to adjacent and regional volcanic sequences. Unique mineralogy, geochemistry and lithologic character of some units (notably Tvb) and volcanic vent facies, as well as the presence of domes and dikes feeding the 
extrusives, argue for local derivation from a dome/stratocone volcanic complex that was mostly restricted to the northern Highland Range.

Faults are dominantly normal, moderately to steeply dipping, and exhibit mostly dip slip. Fault strikes are variable from south to north in the map area, with north to north-northwest strikes in the southern part of the map area becoming northeast-striking in the northern part of the map area. Slip on individual faults is modest, ranging from a few meters to a few tens of meters, but cumulative normal displacement across the area is at least 1 to $2 \mathrm{~km}$.

Tilting of strata in the northern Highland Range was uniform with modest east tilts of ca. $25^{\circ}$ to $30^{\circ}$ on average throughout much of the map area. Local variations in dip owing to deposition on non-horizontal surfaces, original depositional dips, and drag on faults produces dispersion in the data, but otherwise no systematic variation is observed from the base of the Miocene volcanic section to the capping Tuffs of Mt. Davis and Bridge Spring.

The uniform tilts observed in the map area indicate that between 18.27 Ma to 15.00 Ma, when virtually the entire volcanic sequence was erupted, there was no or very limited extension. Relatively uniform and high fault-bedding angles and similar fault orientations are consistent with this interpretation and suggest faults initiated at steep angles to originally horizontal strata and then were rotated to somewhat lower angles during the main phase of extension and tilting. Tilt-fanning observed in the southern Highland Range is not observed in the northern Highland Range, indicating that 
extension commenced earlier in the southern Highland Range and overlapped with the later phases of volcanism there.

The total extension inferred across the northern Highland Range has not been rigorously quantified. The modest tilting contrasts with the steep tilting $\left(\geq 90^{\circ}\right)$ observed in the southern Highland Range for rocks of the same age. Therefore, the relative magnitude of total extension was appreciably less in the northern Highland Range.

The northern Highland Range map area occurs north of the Black Mountains accommodation zone axis. North- to northwest-striking, west-dipping faults resulting in east-tilted strata fit the description of Lake Mead domain faulting found north of the accommodation zone, but northeast-striking faults and dikes in the map area are anomalous. Tilting within the map area cannot be interpreted exclusively as a homoclinally, east-dipping limb of an extensional anticline within the accommodation zone. The proximity of the area to the McCullough Range fault, which is the western breakaway fault to the Whipple domain within the Colorado River extensional corridor, as well as the formation of a basement horst, suggest a complex structural transition between the two tilt domains.

Dikes were emplaced concurrent with normal faulting, and their north to northnorthwest orientations in much of the map area are consistent with broadly east-west to east northeast-west southwest regional extension. In the northernmost Highland Range, dike orientations differ by as much as $90^{\circ}$, suggesting either local variations in extensional strain, perhaps produced by stresses associated with subvolcanic magma chambers, or vertical axis rotation of the northernmost Highland Range. 


\section{REFERENCES CITED}

Allmendinger, R.W., Cardozo, N.C., and Fisher, D., 2013, Structural Geology Algorithms: Vectors and Tensors: Cambridge, England, Cambridge University Press, 289 p.

Anderson, R.E., 1971, Thin skin distension in Tertiary rocks of southeastern Nevada: Geological Society of America Bulletin, v. 82, p. 43-58.

Anderson, R.E., Longwell, C.R., Armstrong R.L., and Marvin, R.F., 1972, Significance of $\mathrm{K}-\mathrm{Ar}$ ages of Tertiary rocks from the Lake Mead region, NevadaArizona: Geological Society of America Bulletin, v. 83, p. 273-288.

Anderson, R.E., Barnhard, T.P., and Snee, L.W., 1994, Roles of plutonism, midcrustal flow, tectonic rafting, and horizontal collapse in shaping the Miocene strain field of the Lake Mead area, Nevada and Arizona: Tectonics, v.13, no. 6, p. 1,3811,410 .

Angelier, J., Colletta, B., and Anderson, R.E., 1985, Neogene paleostress changes in the Basin and Range; a case study at Hoover Dam, Nevada - Arizona: Geological Society of America Bulletin, v. 96, no. 3, p. 347-361.

Axen, G.J. Taylor, W. J. and Bartley, J. M., 1993, Space-time patterns and tectonic controls of Tertiary extension and magmatism in the Great Basin of the western United States: Geological Society of America Bulletin, v. 105, no. 1, p. 56-76.

Bachl, C.A., Miller, C.F., Miller, J.S., and Faulds, J.E., 2001, Construction of a pluton: Evidence from an exposed cross-section of the Searchlight pluton, Eldorado Mountains, Nevada: Geological Society of America Bulletin, v. 113, no. 9, p. 1213-1228.

Bacon, C.R., 1986, Magmatic inclusions in silicic and intermediate volcanic rocks: Journal of Geophysical Research: Solid Earth, v. 91, no. B6, p. 6091-6112.

Bazar, D., Miller, J., Miller, C., Dodge, M., Hodge, K., and Faulds, J., 2006, Eruption of deep mushy magma from the Searchlight magma system, southern Nevada (USA): a crystal size distribution and geochemical analysis: Eos (Transactions, American Geophysical Union), v. 1, p. 1667.

Bingler, E.C., and Bonham, H.F., Jr., 1973, Reconnaissance geologic map of the McCullough Range and adjacent areas, Clark County, Nevada: Nevada Bureau of Mines and Geology Map 45, scale 1:125 000, 1 sheet. 
Cardozo, N., and Allmendinger, R.W., 2013, Spherical projections with OSXStereonet: Computers \& Geosciences, v. 51, no. 0, p. 193-205, doi: 10.1016/j.cageo.2012.07.021.

Christiansen, R.L., and Yeats, R.S., 1992, Post Laramide geology of the U.S. Cordilleran region, in Burchfiel, B.C., Lipman, P.W. and Zoback, M.L., eds., The Cordilleran orogen: conterminous U.S.: Boulder, Colorado, Geological Society of America, The Geology of North America, v. G-3, p. 261-406.

Colombini, L.L., Gualda, G.A.R., Miller, C.F., Faulds, J.E. Miller, J.S., Wooden, J.L. and Mazdab, F., 2008, Mid-Miocene rhyolite sequence, Highland Range, NV: Record magma evolution and eruption from the Searchlight pluton magma chamber: EOS Transactions of the American Geophysical Union, 89(53), Fall Meeting Supplemental Abstract, v. 1, p. 2125.

Darvall, P., 1991, Miocene extension and volcanism in the Eldorado Mountains, southeast Nevada, USA [M.S. thesis]: Monash University, Clayton, Australia.

Davis, S.O., 1984, Structural geology of the central part of the Highland Spring Range, Clark County, Nevada, [M.S. thesis]: University of Southern California.

Dickinson, W.R., 2002, The basin and range province as a composite extensional domain: International Geology Review, v. 44, no. 1, p. 1-38.

Dodge, M.S., Miller, J.S., Faulds, J.E., and Miller, C.F., 2005, An erupted record from the Miocene Searchlight pluton, Nevada: Geological Society of America Abstracts with Programs, v. 37, no. 4. p. 66.

Faulds, J.E., Geissman, J.W., and Mawer, C.K., 1990, Structural development of a major extensional accommodation zone in the Basin and Range province, northwestern Arizona and southern Nevada: Implications for kinematic models of continental extension: Geological Society of America Memoirs 176, p. 37-76.

Faulds, J.E., Geissman, J.W., and Shafiqullah, M., 1992, Implications of paleomagnetic data on Miocene extension near a major accommodation zone in the Basin and Range province, northwestern Arizona and southern Nevada: Tectonics 11, no. 2, p. 204-227.

Faulds, J.E., Feuerbach, D.L., Reagan, M.K., Metcalf, R.V., Gans, P., and Walker, J.D., 1995, The Mt. Perkins block, northwestern Arizona: An exposed cross section of an evolving, preextensional to synextensional magmatic system: Journal of Geophysical Research, v. 100, no. B8, p. 15,249-15,266. 
Faulds, J.E., Varga, R.J., 1998, The role of accommodation zones and transfer zones in the regional segmentation of extended terranes, in Faulds, J.E., Stewart, J.H., eds., Accommodation zones and transfer zones: The regional segmentation of the Basin and Range Province: Geological Society of America Special Paper 323, p. 1-46.

Faulds, J.E., Bell, J.W., 1999, Geologic map of the Nelson SW Quadrangle, Clark County, Nevada: Nevada Bureau of Mines and Geology Open-File Report 99-15, scale 1:24 000 .

Faulds, J.E., Feuerbach, D.L., Miller, C.F., and Smith, E.I., 2001, Cenozoic evolution of the northern Colorado River extensional corridor, southern Nevada and northwest Arizona: Pacific Section of the American Association of Petroleum Geologists Publication GB 78 (also Utah Geological Association Publication 30), p. 239-272.

Faulds, J.E., Olson, E.L., Harlan, S.S., and McIntosh, W.C., 2002a, Miocene extension and fault-related folding in the Highland Range, southern Nevada: A threedimensional perspective: Journal of Structural Geology, v. 24. p. 861-886.

Faulds, J.E., Bell, J.W. and Olson, E. L., 2002b, Geologic map of the Nelson SW quadrangle, Clark County, Nevada: Nevada Bureau of Mines and Geology, Map 134, scale 1:24 000, 1 sheet, 15 p. text.

Faulds, J.E., Miller, C.F., Miller, J.S., and Ludington, S., 2008, The Searchlight magmatic system, southern Nevada and northwest Arizona: Anatomy and evolution of a pre-to syn-extensional putonic-volcanic system in the highly extended Colorado River extensional corridor: Geological Society of America Abstracts with Programs, v. 40, no. 1, p. 85.

Feuerbach, D.L., Smith, E.I., Tangeman, J.A., and Walker, J.D., 1993, The role of the mantle during crustal extension: Constraints from geochemistry of volcanic rocks in the Lake Mead area, Nevada and Arizona: Geological Society of America Bulletin, v. 105, p. 1561-1575.

Feuerbach, D.L., Faulds, J.E., and Reagan, M.K., 1999, Interrelations between magmatism and extension in a major accommodation zone, southern Nevada and northwest Arizona, Nevada Petroleum Society Guidebook, v. 14, p. 115-138.

Glazner, A.F., Nielson, J.E., Howard, K.A., and Miller, D.M., 1986, Correlation of the Peach Spring Tuff, a large-volume Miocene ignimbrite sheet in California and Arizona: Geology, v. 14, p. 840-843.

Gans, P.B., and Bohrson, W.A., 1998, Suppression of volcanism during rapid extension in the Basin and Range province, United States: Science, v. 279, p. 66-68. 
Harlan, S.S., Duebendorfer, E.M., and Deibert, J.E., 1998, 40Ar/39Ar age determinations from Miocene volcanic rocks in the western Lake Mead area and southern Las Vegas Range, Nevada: Canadian Journal of Earth Sciences, v. 35, p. 495-503.

Hawkesworth, C., Turner, S., Gallagher, K., Hunter, A., Bradshaw, T., and Rogers, N., 1995, Calc-alkaline magmatism, lithospheric thinning and extension in the Basin and Range: Journal of Geophsycial Research, v. 100, p. 10,271-10,286.

Hooper, P.R., Johnson, D.M., and Conry, R.M., 1993, Major and trace element analyses of rocks and minerals by automated x-ray spectrometry: open file report, GeoAnalylytical Lab., Washington State University, Geology Department, Pullman, p. 36.

Howard, K.A., 1991, Intrusion of horizontal dikes: Tectonic significance of Middle Proterozoin diabase sheets widespread in the upper crust of the southwestern United States: Journal of Geophysical Research, v. 96, no. B7, p. 12,461-12,478.

Howard, K.A., and John, B.E., 1987, Crustal extension along a rooted system of imbricate low-angle faults; Colorado River extensional corridor, California and Arizona: Geological Society of London, Geological Society Special Publications, v. 28, p. 299-311.

Johnson, D.M., Hooper, P.R., and Conrey, R.M., 1999, Advances in X-ray Analysis: GeoAnalytical Lab, Washington State University, vol 41, p. 843-867.

Johnson, B. M., Miller, J. S., Miller, C. F., Wooden, J. L., \& Colombini, L. L., 2014, Thermal and compositional evolution of the Mid-Miocene Searchlight magmatic system as recorded in zircon: American Geophysical Union Abstracts, v. 1, p. 2554.

Knaack, C., Cornelius, S.B., and Hooper, P.R., 1995, Trace element analysis of rocks and minerals by ICP-MS: open-file report, GeoAnalytical Lab, Washington State University, Geology Department, Pullman, p. 18.

Lipman, P.W., 1992, Magmatism in the Cordilleran United States: progress and problems in Burchfiel, B.C., Lipman, P.W. and Zoback, M.L., eds., The Cordilleran orogen: conterminous U.S.: Boulder, Geological Society of America, The Geology of North America, v. G-3, p. 481-513.

Longwell, C.R., 1963, Reconnaissance geology between Lake Mead and Davis Dam, Arizona-Nevada: United States Geological Survey, Professional Paper 374-E, p. 51. 
McDonough, W.F., and Sun, S-S, 1995. The composition of the Earth: Chemical Geology, v. 120, no. 3, p. 223-253.

Metcalf, R.V., Smith, E.I., Walker, J.D., Reed, R.C., and Gonzales, D.A., 1995, Isotopic disequilibrium among commingled hybrid magmas; evidence for a two-stage magma mixing-commingling process in the Mt. Perkins Pluton, Arizona: Journal of Geology, v. 103, p. 509-527.

Metcalf, R.V., 2004, Volcanic-plutonic links, plutons as magma chambers and crustmantle interaction: a lithospheric scale view of magma systems: Transactions of the Royal Society of Edinburgh-Earth Sciences, v. 95 no.1-2, p. 357-374.

Miller, C.F., and J.S. Miller, 2002, Contrasting stratified plutons exposed in tilt blocks, Eldorado Mountains, Colorado River rift, Nevada: Lithos, v. 61, p. 209-224.

Miller, J.S., Glazner, A.F., Farmer, G.L., Suayah, I.B., and Keith, L.A., 2000, A Sr, Nd, and $\mathrm{Pb}$ isotopic study of mantle domains and crustal structure from Miocene volcanic rocks in the Mojave Desert, California: Geological Society of America Bulletin, v. 112, p. 1264-1279.

Miller, J, Miller, C, Wooden, J, Perrault, D, Hodge, K, Faulds, J, Cates, N, and Means, M, 2006, A 2 Million Year History of Plutonism and Volcanism in the Searchlight magma system, Eldorado Mountains, Nevada (USA), Eos (Transactions, American Geophysical Union), v. 1, p. 1714.

Morikawa, S. A., 1994, The geology of the tuff of Bridge Spring, southern Nevada and northwestern Arizona [M.S. thesis]: University of Nevada, Las Vegas.

Nielson, J.E., Lux, D.R., Dalrymple, G.B., and Glazner, A.F., 1990, Age of the Peach Springs Tuff, southeastern California and western Arizona: Journal of Geophysical Research, v. 95, p. 571-580.

Nielson, J.E., and Beratan, K.K., 1995, Tertiary basin development and tectonic implications, Whipple detachment system, Colorado River extensional corridor, California and Arizona: Journal of Geophysical Research, v. 95, p. 599-614.

Olson, E.L., 1996. Geometry and kinematics of an extensional anticline, Highland Spring Range, southern Nevada [M.S. thesis]: University of Iowa.

Platt, J.P., and England, P.C., 1994, Convective removal of lithosphere beneath mountain belts: Thermal and mechanical consequences: American Journal of Science, v. 293, p. 307-336. 
Spencer, J.E., 1985, Miocene low-angle normal faulting and dike emplacement, Homer Mountain and surrounding areas, southeastern California and southernmost Nevada: Geological Society of American Bulletin, v. 96, p. 1,140-1,155.

Sun, S.S. and McDonough, W.F., 1989, Chemical and isotopic systematics of oceanic basalts: Implications for mantle composition and processes, in Saunders, A.D., Norry, M.J., eds., Magmatism in Ocean Basins: Geological Society, London, Special Publications 42, no. 1, p. 313-345.

Smith, J., Miller, J., Koteas, C., and Miller, C., 2008, Incorporation of host rock blocks during growth of the Aztec Wash pluton, Eldorado Mountains, Nevada: Geological Society of America Abstracts with Programs, v. 40, no. 1, p. 92.

Smith, E., Honn, D., 2010, Volcanoes of the McCullough Range, southern Nevada: Geological Society of America Special Papers 463, p. 203-219.

Sonder, L.J. and Jones, C. H., 1999, Western United States extension: How the west was widened: Annual Reviews of Earth and Planetary Sciences, v. 27, p. 417-462.

Varga, R. J. Faulds, J.E., Snee, L.W., and Harlan, S.S., 2004, Miocene extension and extensional folding in a anticlinal segment of the Black Mountain accommodation zone, Colorado River Extensional Corridor, southwestern United States: Tectonics, v. 23, no. 1, p.1-19.

Walker, B.A. Jr., Miller, C.F., Claiborne, L.E., Wooden, J.L., and Miller, J.S., 2007, Geology and geochronology of the Spirit Mountain batholith, southern Nevada: implications for timescales and physical processes of batholith construction: Journal of Volcanology and Geothermal Research v. 167, no. 1, p. 239-262.

Wells, M.L., and Hoisch, T.D., 2008, The role of mantle delamination in widespread Late Cretaceous extension and magmatism in the Cordilleran orogen, western United States: Geological Society of America Bulletin, v. 120, no. 5-6, p. 515-530.

Wernicke, B., 1990, Basin and Range Extensional Tectonics near the latitude of Las Vegas, Nevada: Geological Society of America Memoir 176, p. 1-500.

Wernicke, B., 1992, Cenozoic extensional tectonics of the U.S. Cordillera, in Burchfiel, B.C., Lipman, P.W. and Zoback, M.L., eds., The Cordilleran orogen: conterminous U.S.: Boulder, Geological Society of America, v. G-3, p. 553-581.

Wooden, J.L., and Miller, D.M., 1990, Chronologic and isotopic framework for early proterozoic crustal evolution in the eastern Mojave Desert region, SE California: Journal of Geophysical Research, Solid Earth, v. 95, no. B12, p. 20,133 - 20,146. 
APPENDIX A: Photomicrographs

\begin{tabular}{|c|c|c|c|}
\hline Rock ID & Unit & Description & $\begin{array}{l}\text { Location } \\
\text { UTM zone S11 }\end{array}$ \\
\hline $98 A^{*}$ & Thbb & Highland Range basal trachyandesite & $\begin{array}{l}675808 \mathrm{~N} \\
3945831 \mathrm{E}\end{array}$ \\
\hline $14 \mathrm{~A}^{*}$ & Thd & Trachydacite domes and flows & $\begin{array}{l}675704 \mathrm{~N} \\
3944897 \mathrm{E}\end{array}$ \\
\hline $362 B^{*}$ & Thd & Trachydacite domes and flows & $\begin{array}{l}676540 \mathrm{~N} \\
3945605 \mathrm{E}\end{array}$ \\
\hline $105 A^{*}$ & Thb & $\begin{array}{l}\text { Volcanics of the Highland Range - } \\
\text { trachyandesite flows }\end{array}$ & $\begin{array}{l}676656 \mathrm{~N} \\
3945872 \mathrm{E}\end{array}$ \\
\hline $228 A^{*}$ & Thb & $\begin{array}{l}\text { Volcanics of the Highland Range - } \\
\text { trachyandesite flows }\end{array}$ & $\begin{array}{l}677394 \mathrm{~N} \\
3948320 \mathrm{E}\end{array}$ \\
\hline $229 A^{*}$ & Tvb & Volcanic breccia: lithic tuff and debris flows & $\begin{array}{l}677763 \mathrm{~N} \\
3948662 \mathrm{E}\end{array}$ \\
\hline $78 A^{*}$ & $\begin{array}{l}\text { Tvb } \\
\text { (clast) }\end{array}$ & Volcanic breccia: lithic tuff and debris flows & $\begin{array}{l}677902 \mathrm{~N} \\
3943521 \mathrm{E} \\
\end{array}$ \\
\hline $305 \mathrm{~A}^{*}$ & Thb & $\begin{array}{l}\text { Volcanics of the Highland Range - } \\
\text { trachyandesite flows }\end{array}$ & $\begin{array}{l}678217 \mathrm{~N} \\
3945332 \mathrm{E}\end{array}$ \\
\hline $9 \mathrm{~B}^{*}$ & Thbi & Trachyandesite and Trachydacite dikes & $\begin{array}{l}678784 \mathrm{~N} \\
3949393 \mathrm{E} \\
\end{array}$ \\
\hline $201 A^{*}$ & Thb & $\begin{array}{l}\text { Volcanics of the Highland Range - } \\
\text { trachyandesite flows }\end{array}$ & $\begin{array}{l}679277 \mathrm{~N} \\
3950094 \mathrm{E}\end{array}$ \\
\hline $3 \mathrm{~A}$ & Tvb & Volcanic breccia: lithic tuff and debris flows & $\begin{array}{l}678711 \mathrm{~N} \\
3944688 \mathrm{E}\end{array}$ \\
\hline 8B & Tvb & Volcanic breccia: lithic tuff and debris flows & $\begin{array}{l}679179 \mathrm{~N} \\
3950090 \mathrm{E}\end{array}$ \\
\hline $10 \mathrm{~A}$ & Tvb & Volcanic breccia: lithic tuff and debris flows & $\begin{array}{l}678916 \mathrm{~N} \\
3948564 \mathrm{E}\end{array}$ \\
\hline 41 & Thbb & Highland Range basal trachyandesite & $\begin{array}{l}678205 \mathrm{~N} \\
3940192 \mathrm{E} \\
\end{array}$ \\
\hline $48 \mathrm{~A}$ & Thbi & Trachyandesite and Trachydacite dikes & $\begin{array}{l}678510 \mathrm{~N} \\
3944701 \mathrm{E}\end{array}$ \\
\hline 52B & Tvb & Volcanic breccia: lithic tuff and debris flows & $\begin{array}{l}677867 \mathrm{~N} \\
3951287 \mathrm{E}\end{array}$ \\
\hline $56 \mathrm{~A}$ & Thd & Trachydacite domes and flows & \begin{tabular}{|l}
$675243 \mathrm{~N}$ \\
$3945991 \mathrm{E}$ \\
\end{tabular} \\
\hline $58 \mathrm{~A}$ & Thd & Trachydacite domes and flows & $\begin{array}{l}675901 \mathrm{~N} \\
3945980 \mathrm{E}\end{array}$ \\
\hline $64 \mathrm{~A}$ & Thbi & Trachyandesite and Trachydacite dikes & $\begin{array}{l}678288 \mathrm{~N} \\
3928550 \mathrm{E}\end{array}$ \\
\hline
\end{tabular}

*Sample analyzed for whole rock geochemistry. 
APPENDIX A: Photomicrographs (continued)

\begin{tabular}{|l|l|l|l|}
\hline Rock ID & Unit & Description & $\begin{array}{l}\text { Location } \\
\text { UTM zone S11 }\end{array}$ \\
\hline 68B & Thb & $\begin{array}{l}\text { Volcanics of the Highland Range - } \\
\text { trachyandesite flows }\end{array}$ & $\begin{array}{l}677772 \mathrm{~N} \\
3940921 \mathrm{E}\end{array}$ \\
\hline 69A & Thb & $\begin{array}{l}\text { Volcanics of the Highland Range - } \\
\text { trachyandesite flows }\end{array}$ & $\begin{array}{l}679954 \mathrm{~N} \\
3949015 \mathrm{E}\end{array}$ \\
\hline 70D & Tvb & Volcanic breccia: lithic tuff and debris flows & $679017 \mathrm{~N}$ \\
& & 3941413 E \\
\hline 367A & $\mathrm{Xg}$ & Diabase dike within Orthogneiss & $675577 \mathrm{~N}$ \\
& & & $3947068 \mathrm{E}$ \\
\hline
\end{tabular}


98A Thbb - Highland Range basal trachyandesite

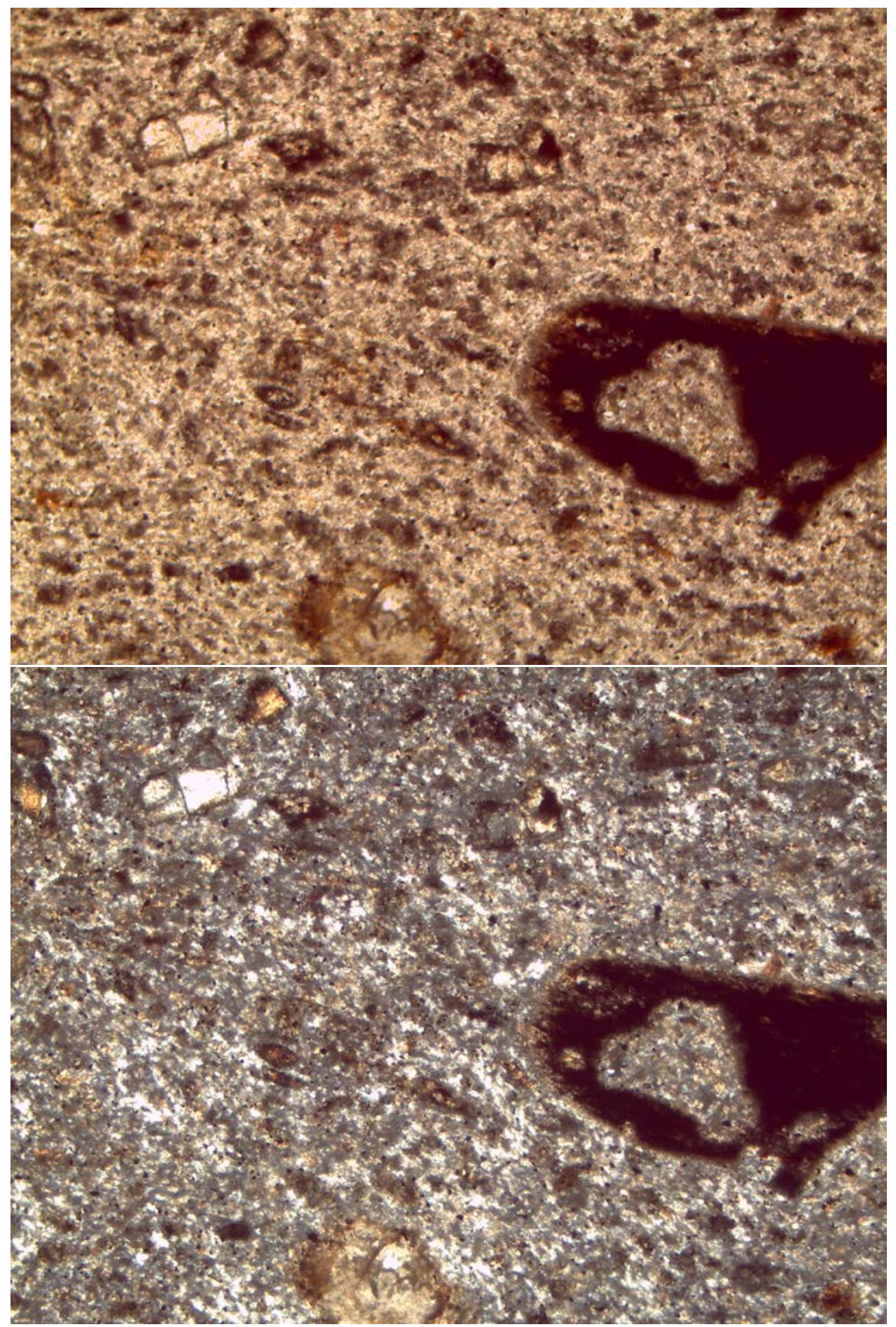

Width of field of view is $3 \mathrm{~mm}$. 
14A Thd - Trachydacite domes and flows

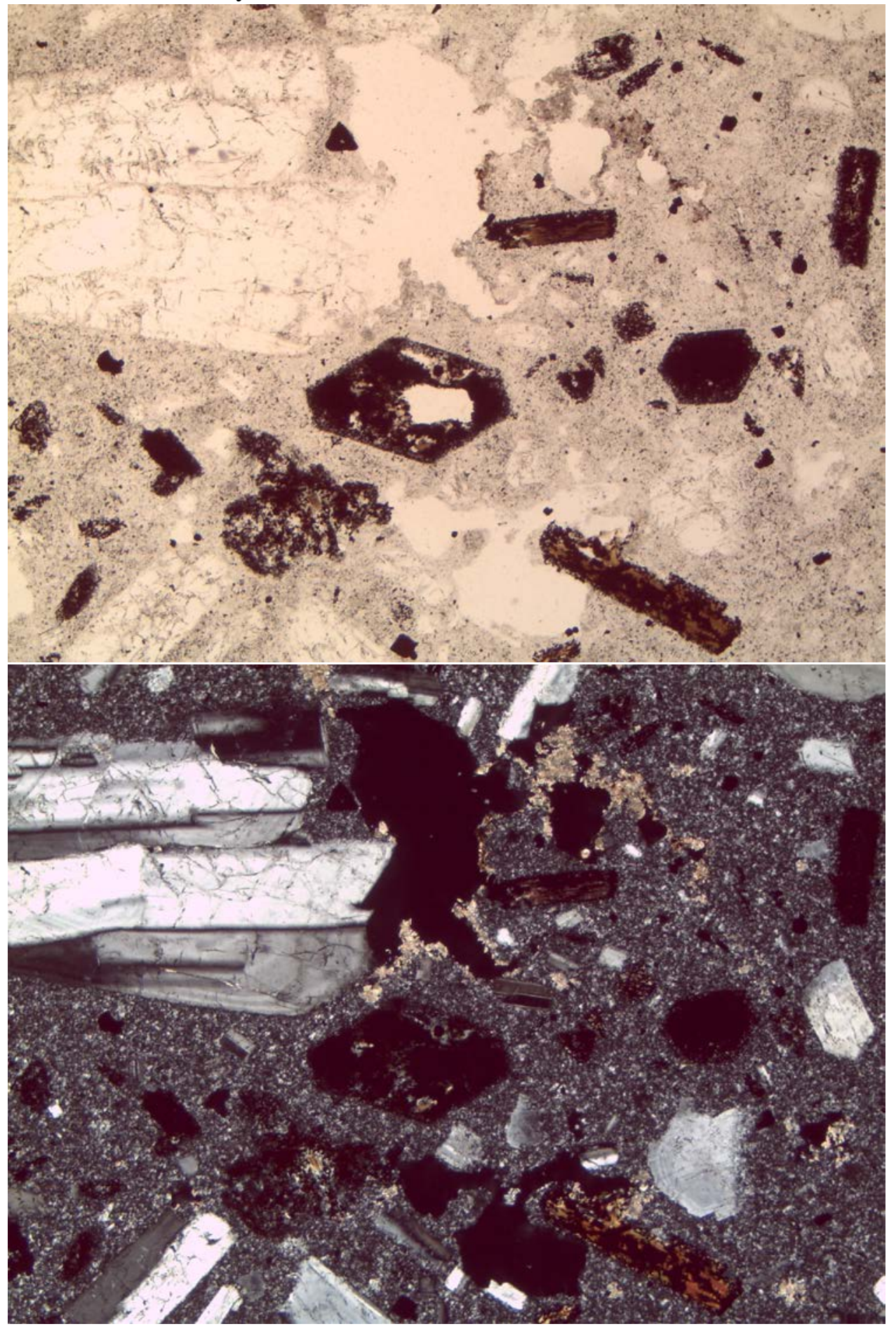

Width of field of view is $3 \mathrm{~mm}$. 
362B Thd - Trachydacite domes and flows (first view)

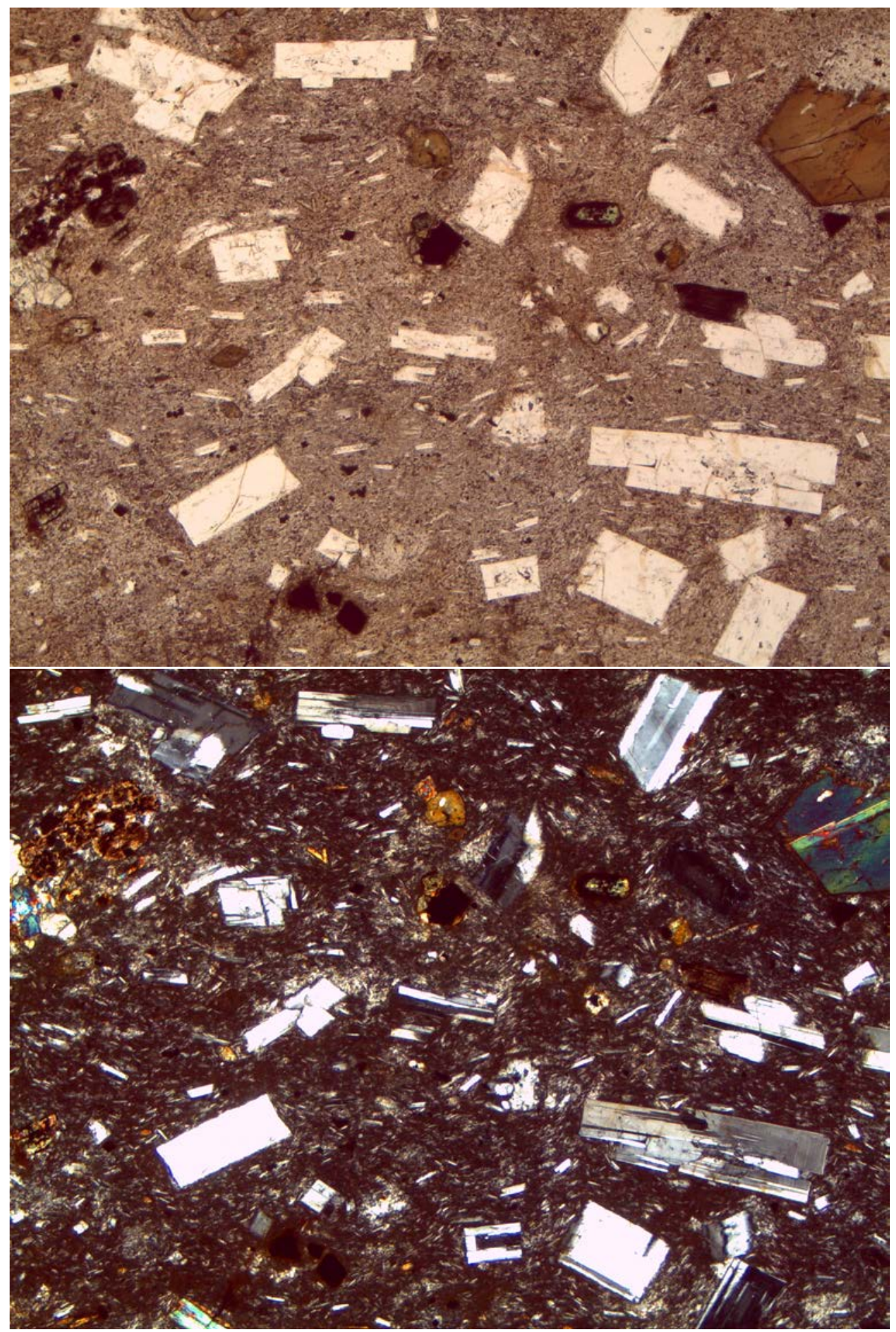

Width of field of view is $3 \mathrm{~mm}$. 
362B Thd - Trachydacite domes and flows (second view)

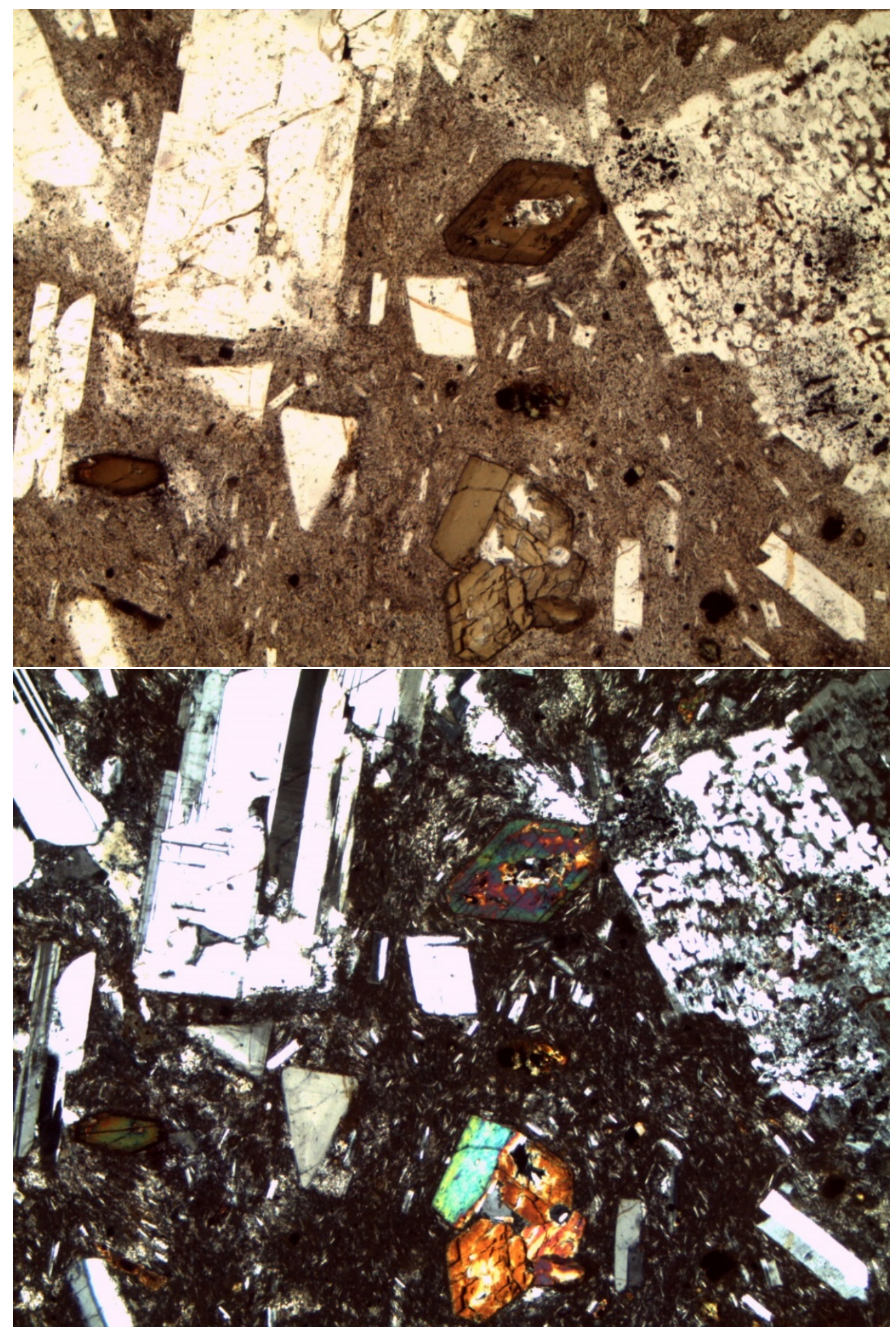

Width of field of view is $3 \mathrm{~mm}$. 
105A Thb - Volcanics of the Highland Range - trachyandesite flows

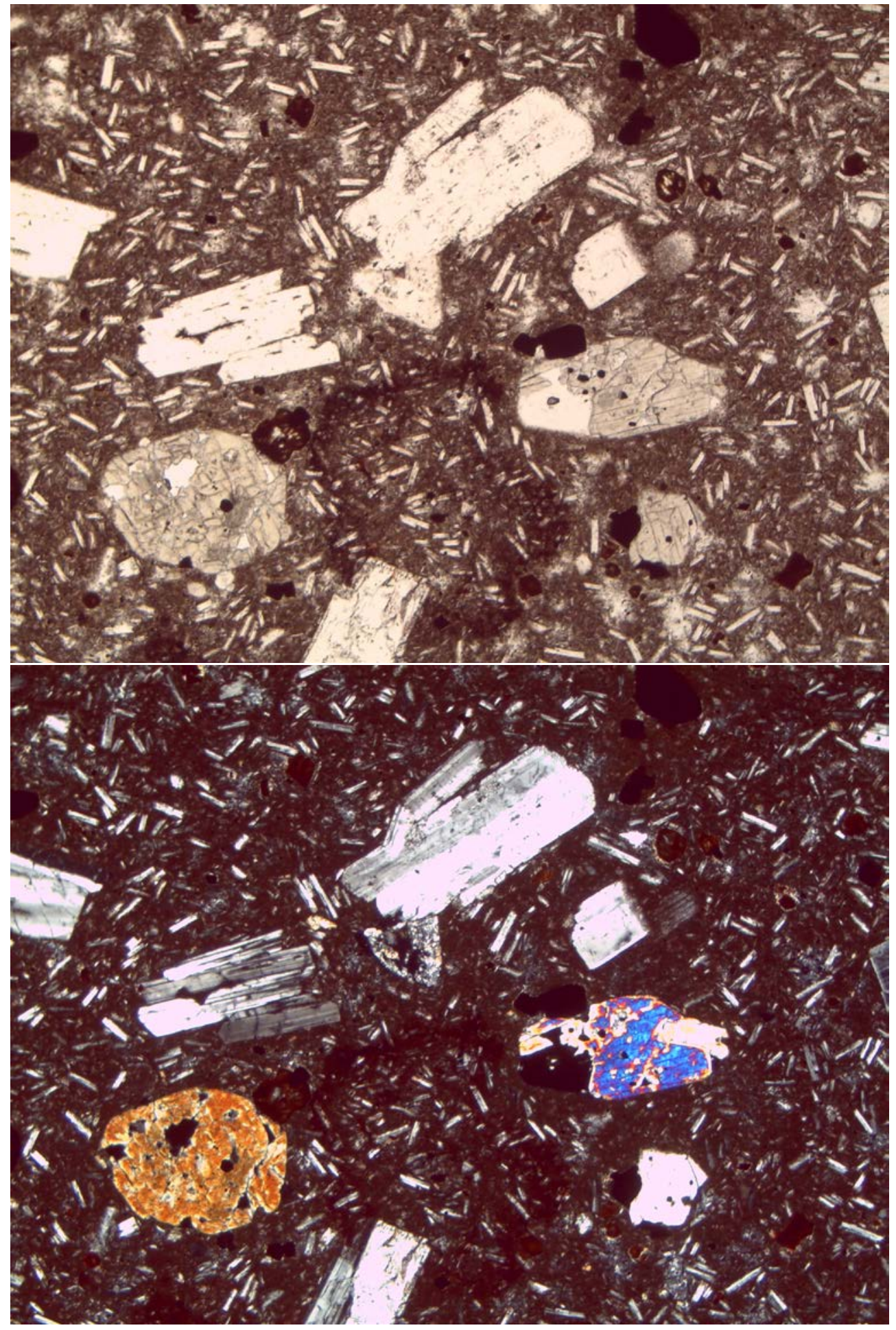

Width of field of view is $3 \mathrm{~mm}$. 
228A Thb - Volcanics of the Highland Range - trachyandesite flows
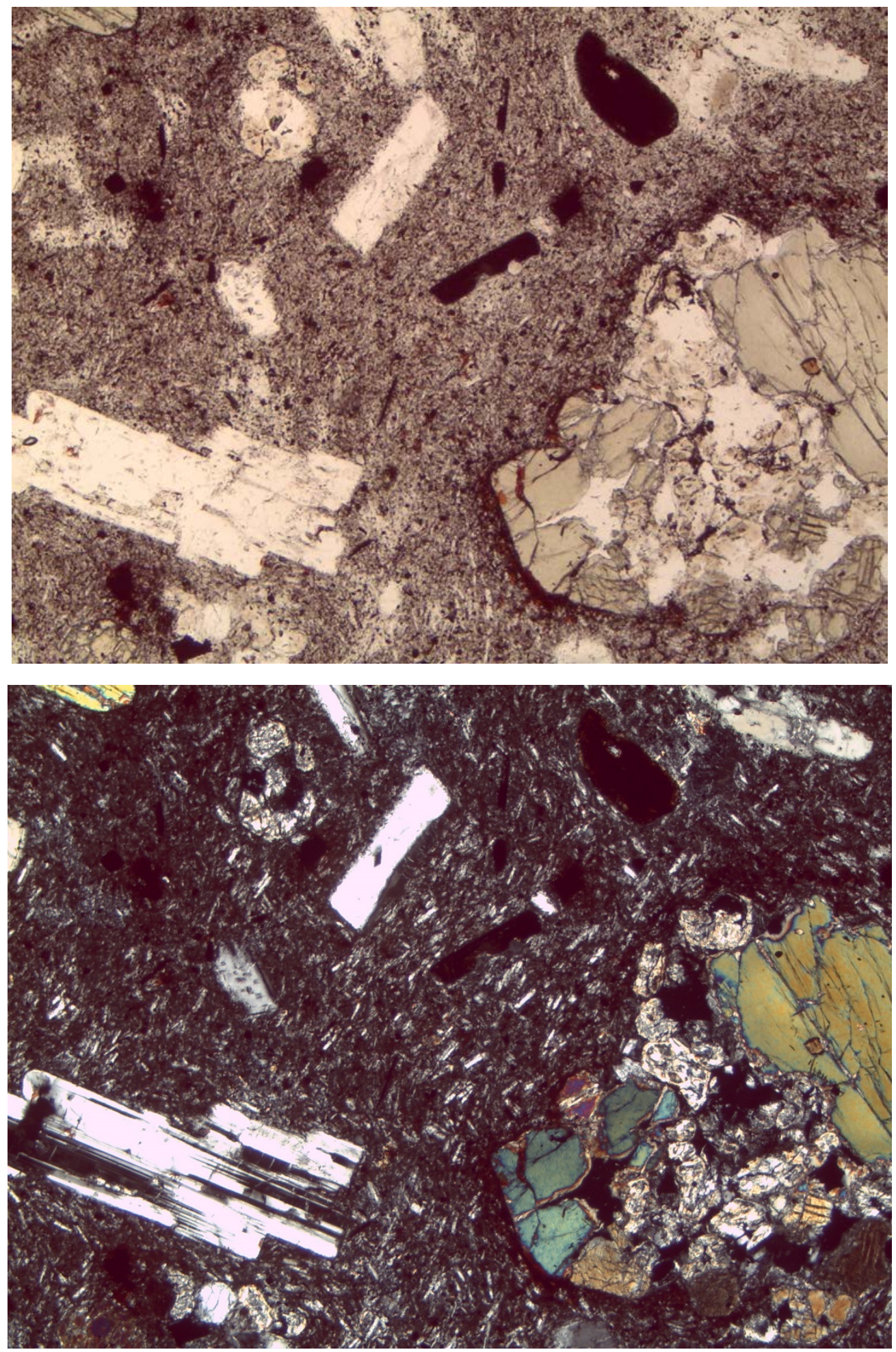

Width of field of view is $3 \mathrm{~mm}$. 
229A Tvb - Volcanic breccia: lithic tuff and debris flows

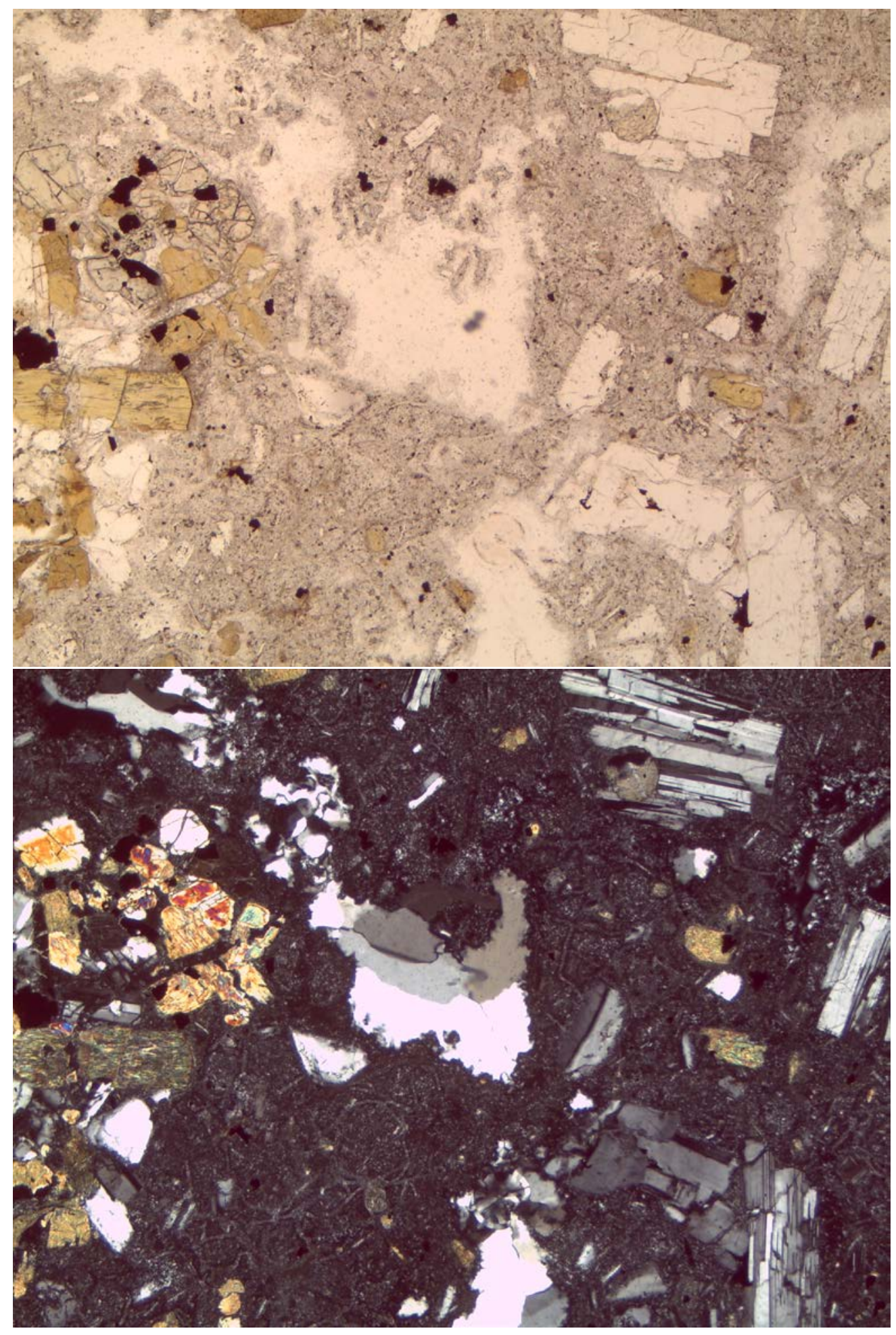

Width of field of view is $3 \mathrm{~mm}$. 
78A Tvb - Volcanic breccia: lithic tuff and debris flows (clast within matrix)

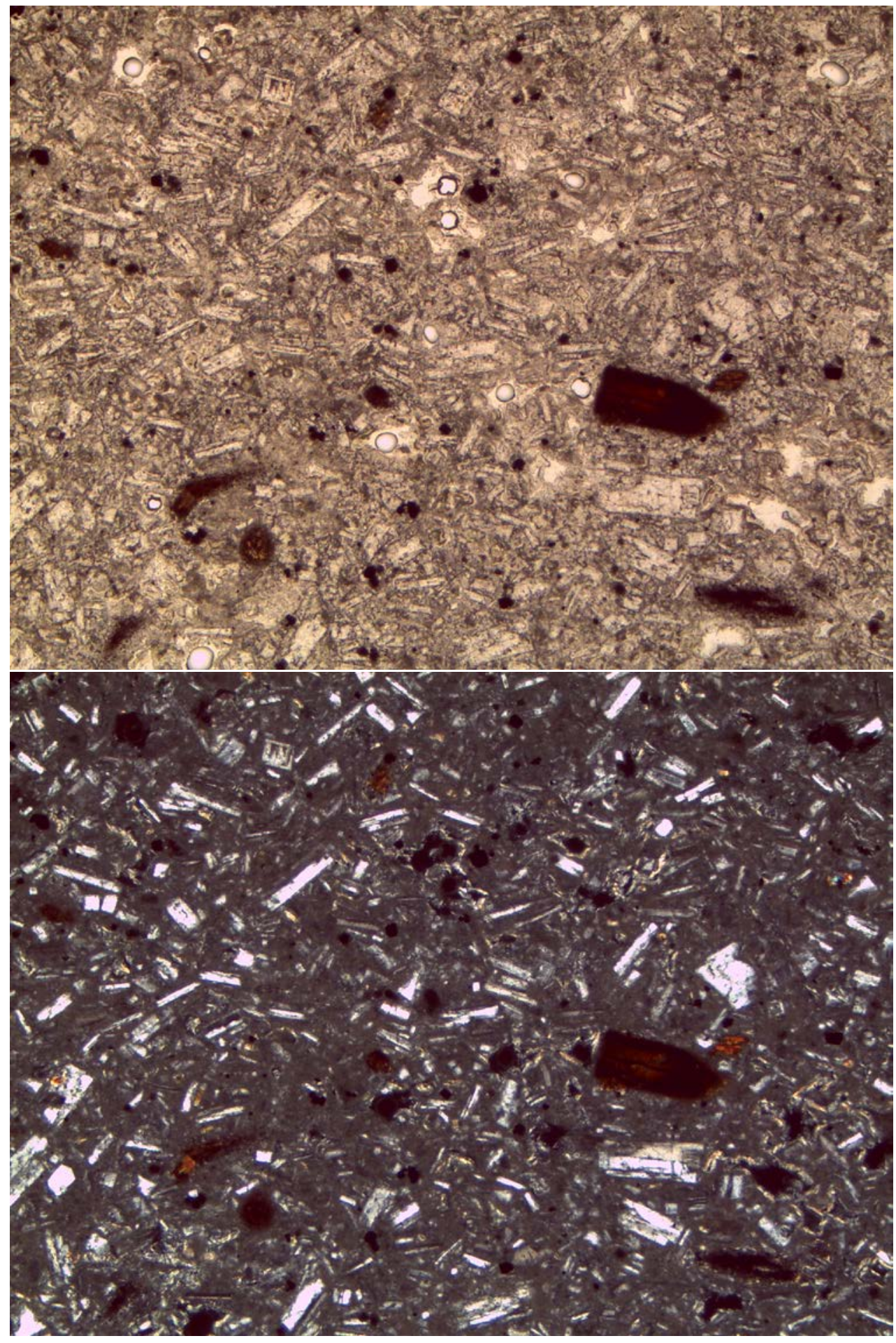

Width of field of view is $3 \mathrm{~mm}$. 
305A Thb - Volcanics of the Highland Range - trachyandesite flows

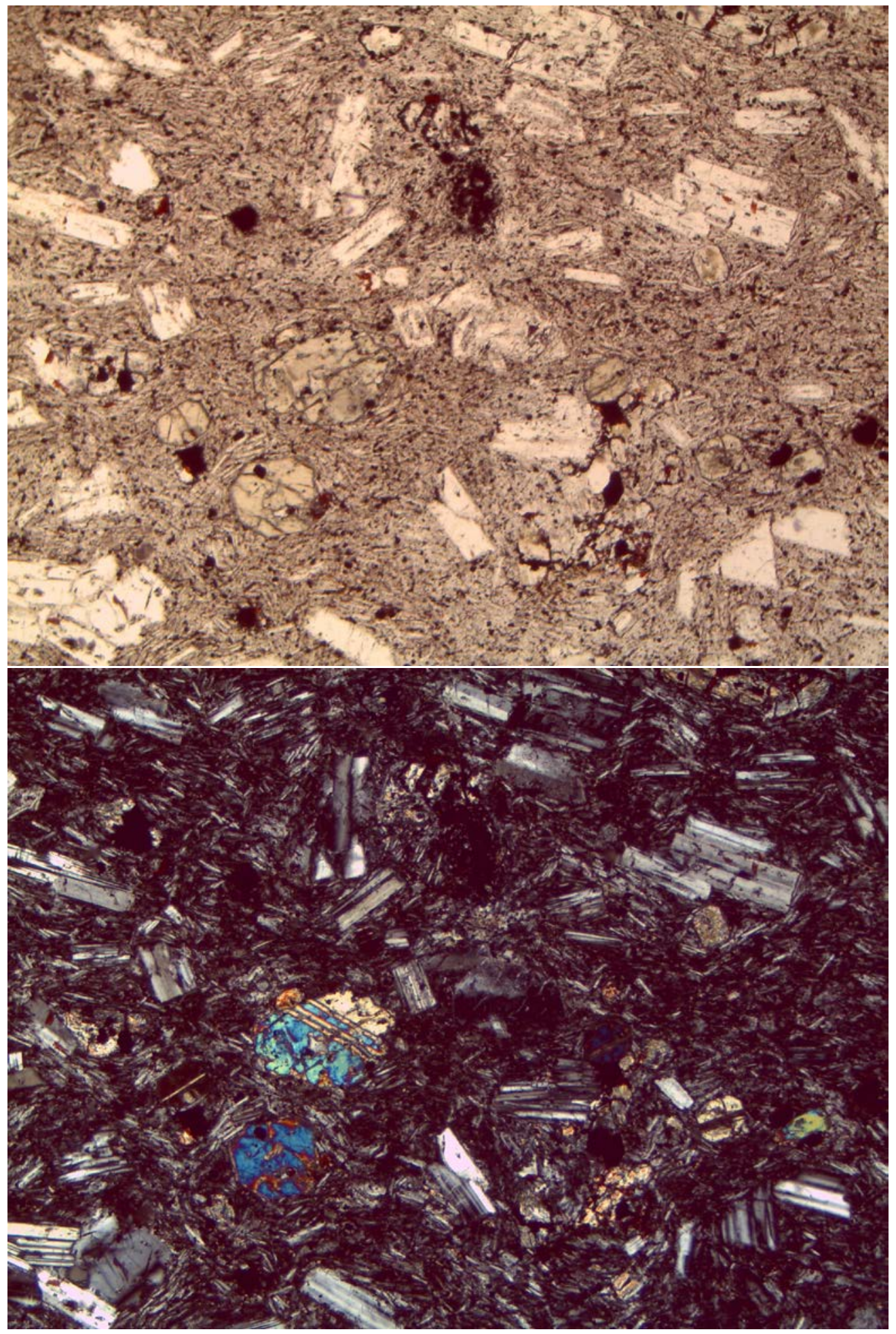

Width of field of view is $3 \mathrm{~mm}$. 
9B Thbi - Trachyandesite and Trachydacite dikes

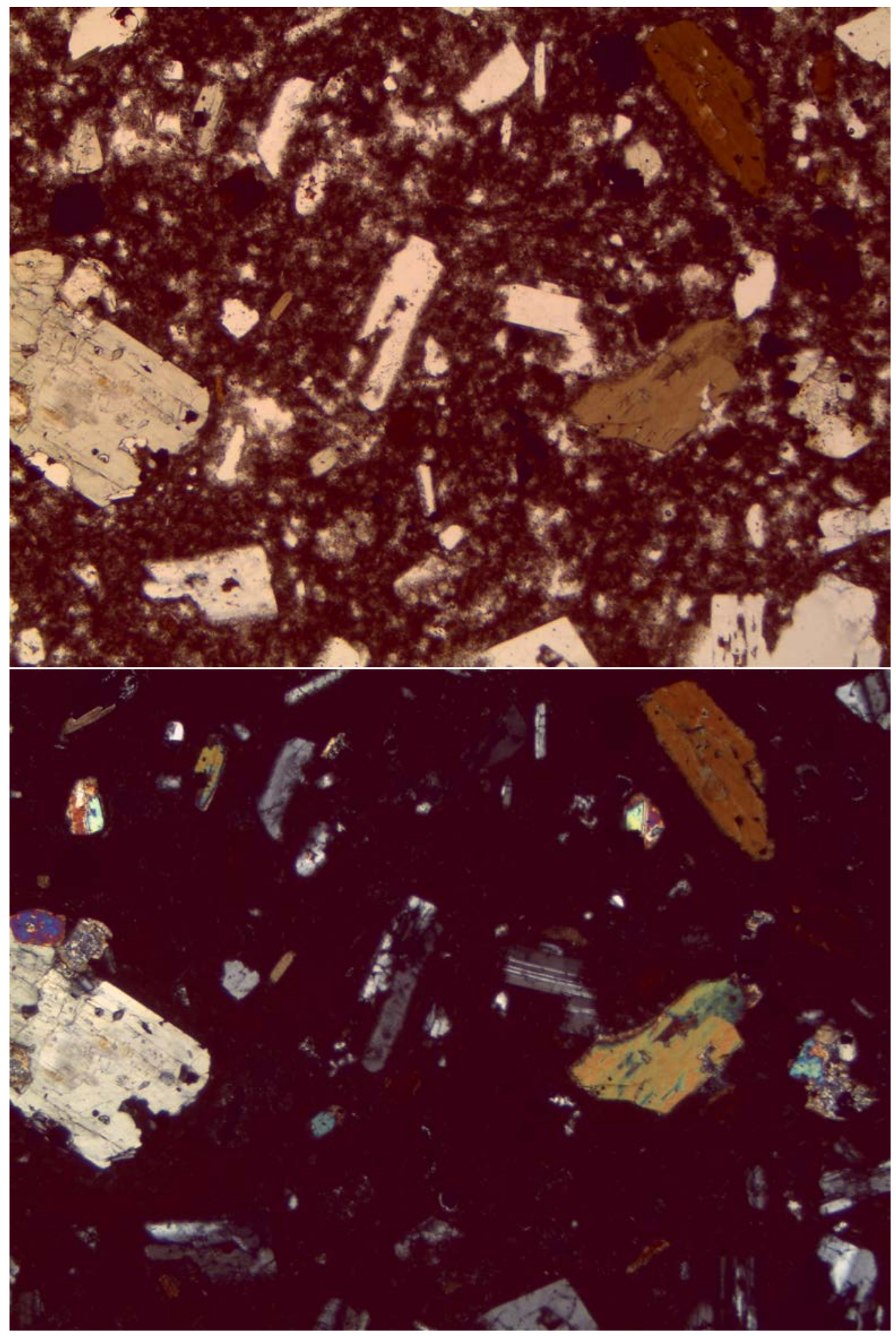

Width of field of view is $3 \mathrm{~mm}$. 
201A Thb - Volcanics of the Highland Range - trachyandesite flows

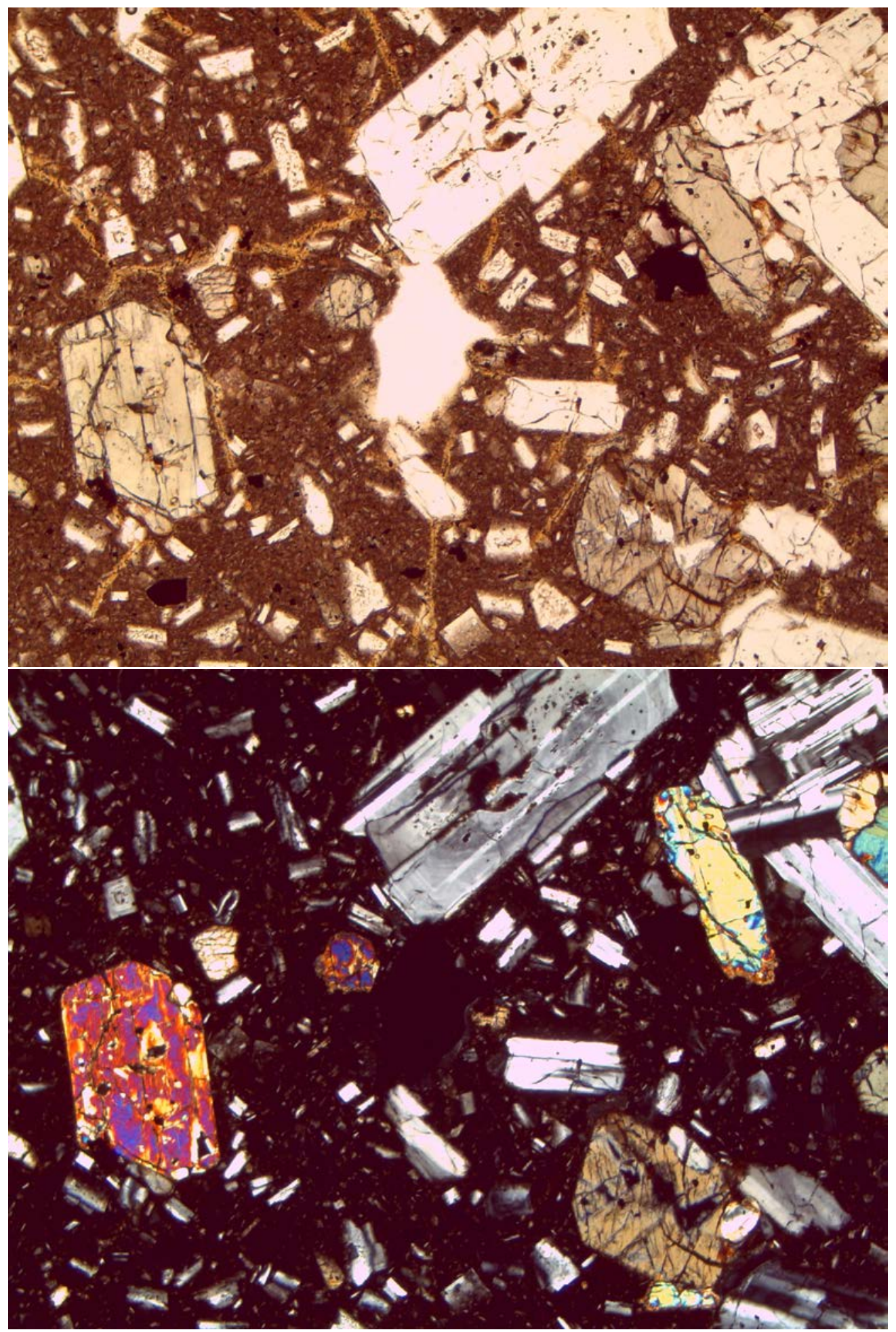

Width of field of view is $3 \mathrm{~mm}$. 
3A Tvb - Volcanic breccia: lithic tuff and debris flows

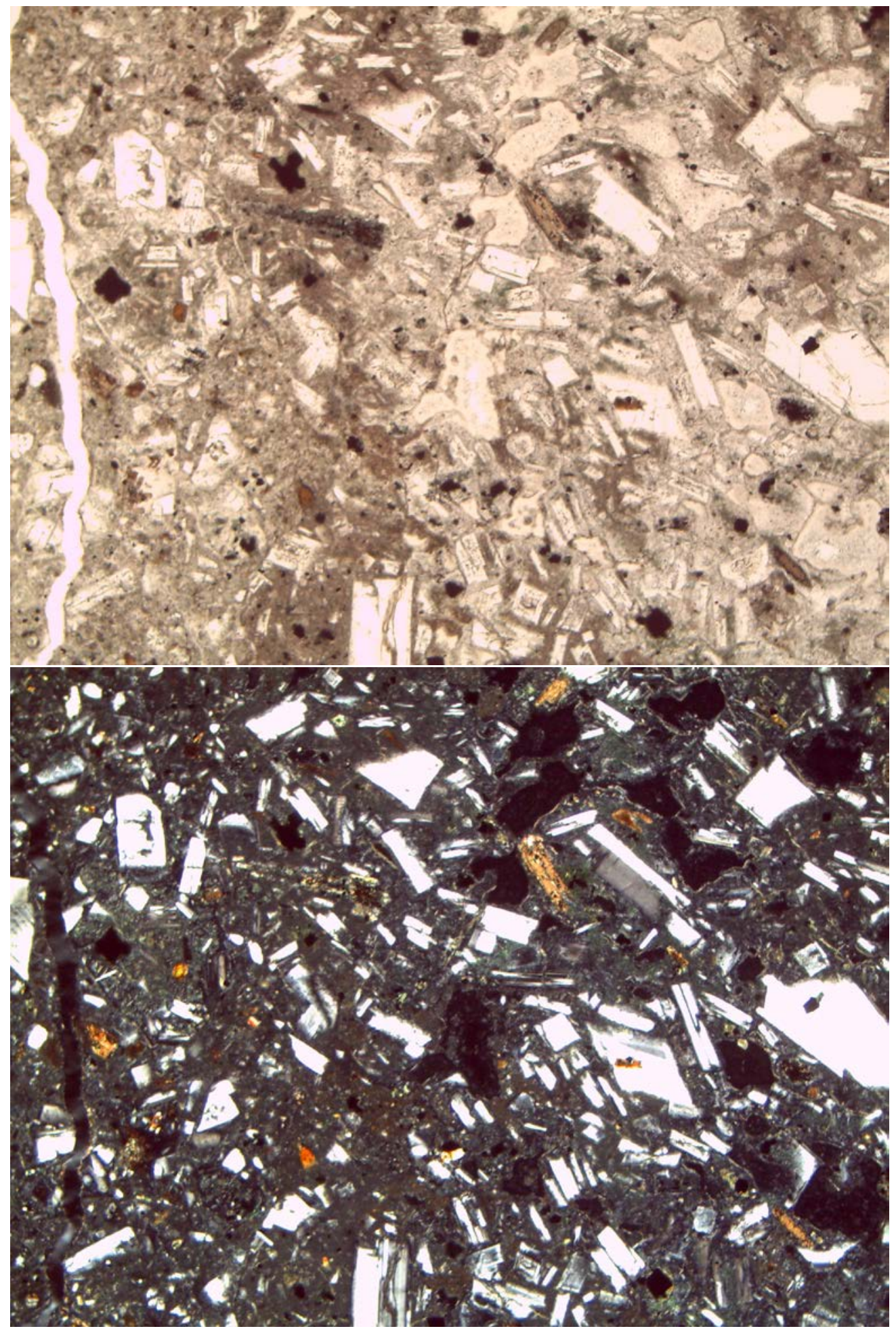

Width of field of view is $3 \mathrm{~mm}$. 
8B Tvb - Volcanic breccia: lithic tuff and debris flows

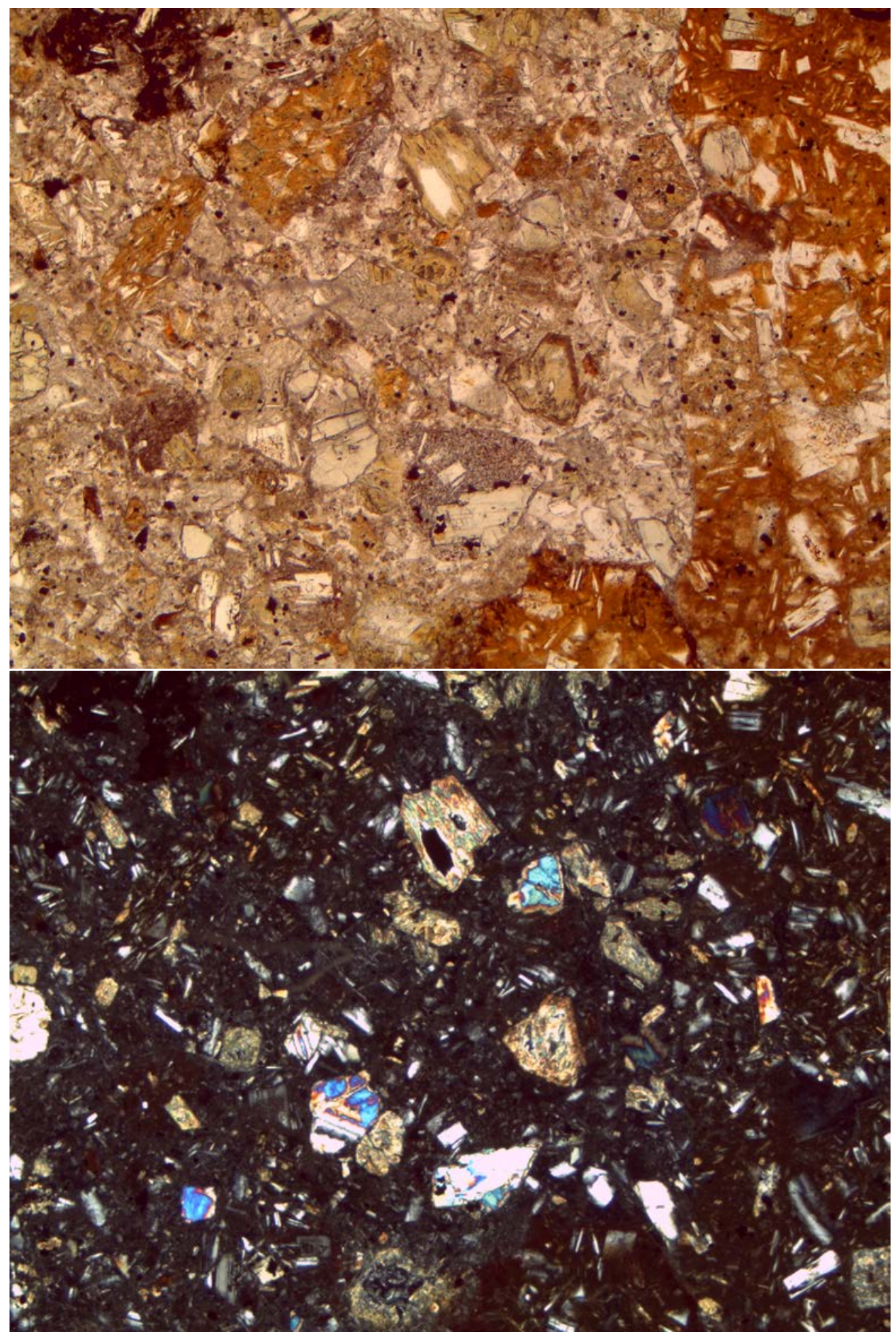

Width of field of view is $3 \mathrm{~mm}$. 
10A Tvb - Volcanic breccia: lithic tuff and debris flows

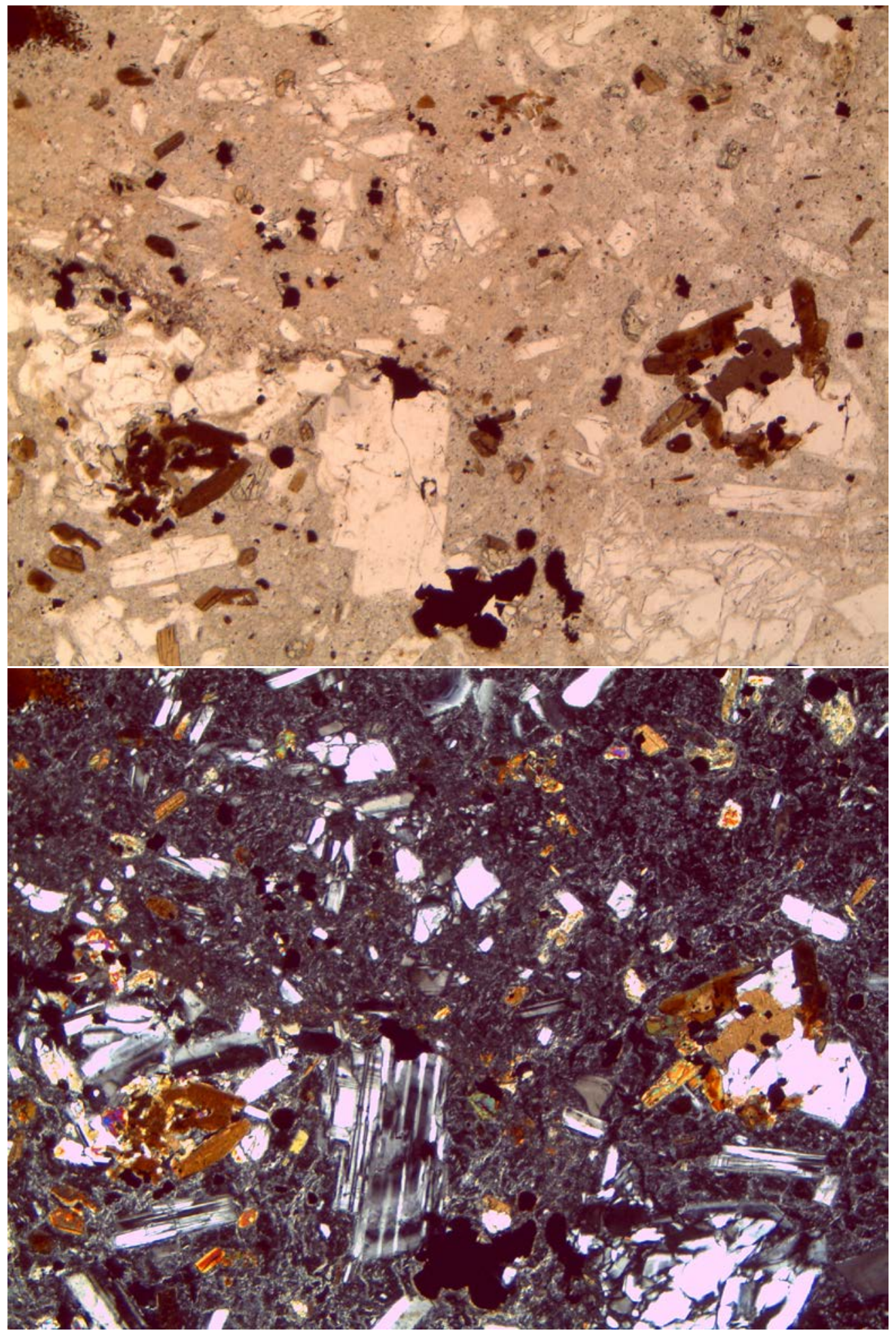

Width of field of view is $3 \mathrm{~mm}$. 
41 Thbb - Highland Range basal trachyandesite

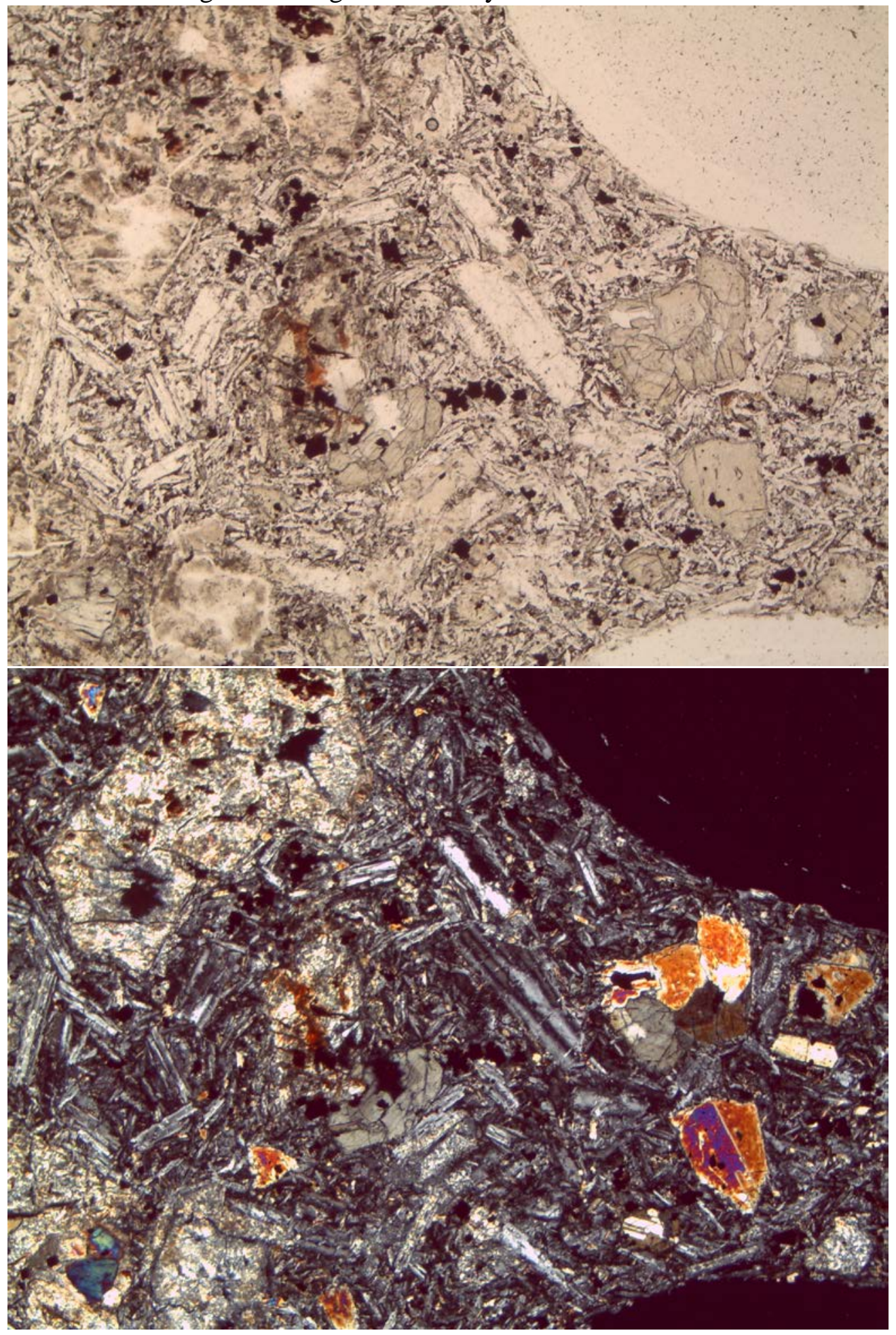

Width of field of view is $3 \mathrm{~mm}$. 
48A Thbi - Trachyandesite and Trachydacite dikes

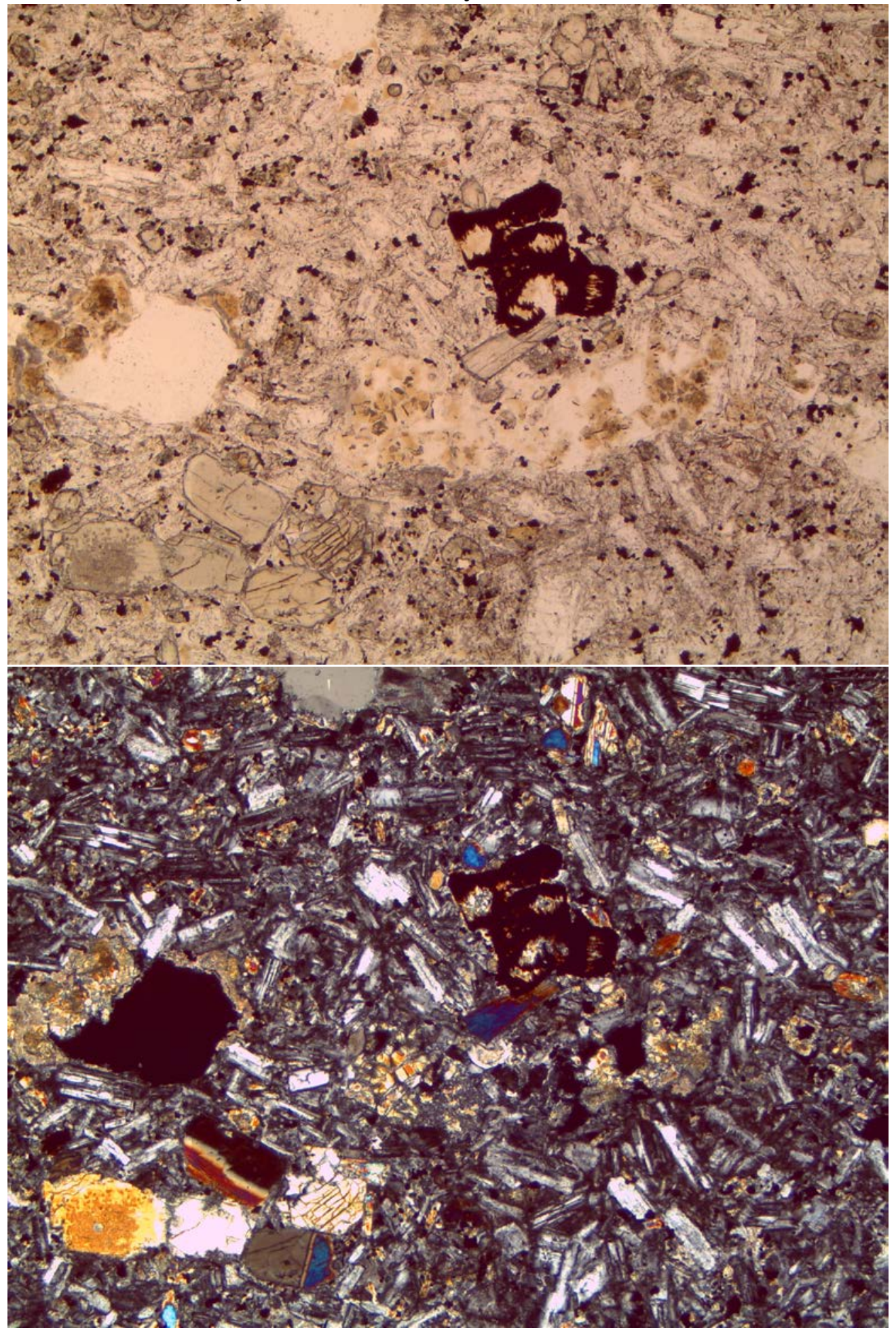

Width of field of view is $3 \mathrm{~mm}$. 
52B Tvb - Volcanic breccia: lithic tuff and debris flows

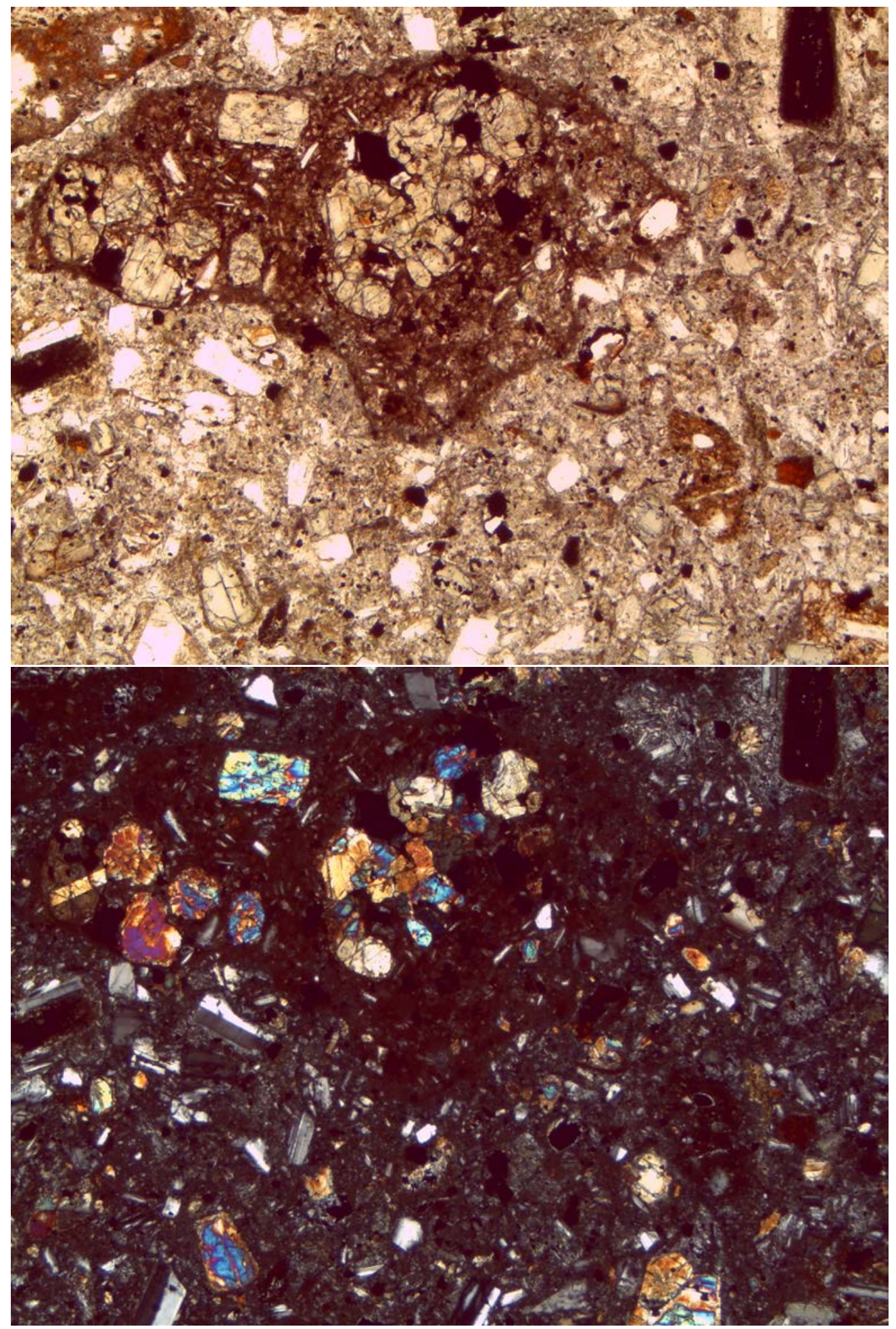

Width of field of view is $3 \mathrm{~mm}$. 
56A Thd - Trachydacite domes and flows

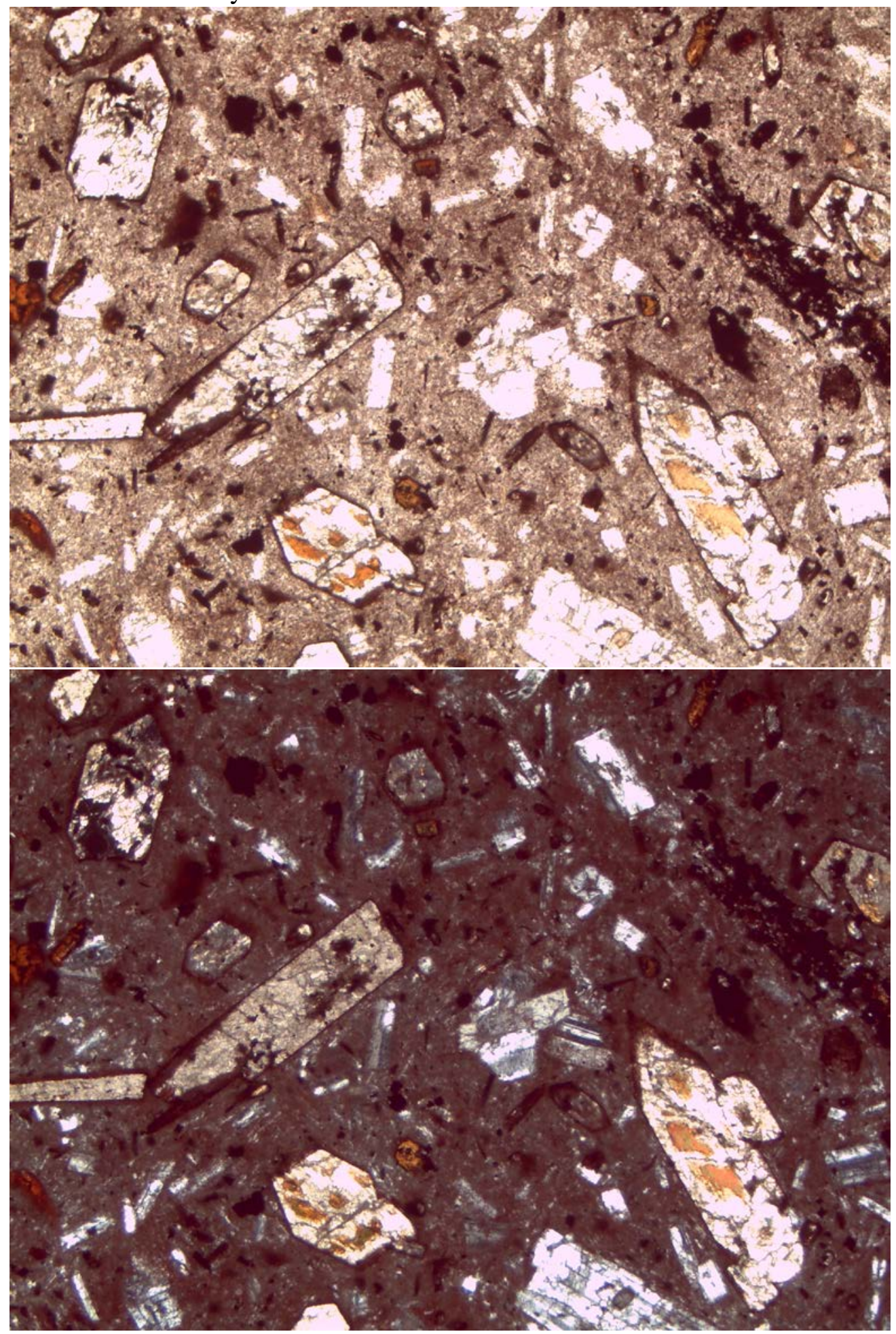

Width of field of view is $3 \mathrm{~mm}$. 
58A Thd - Trachydacite domes and flows

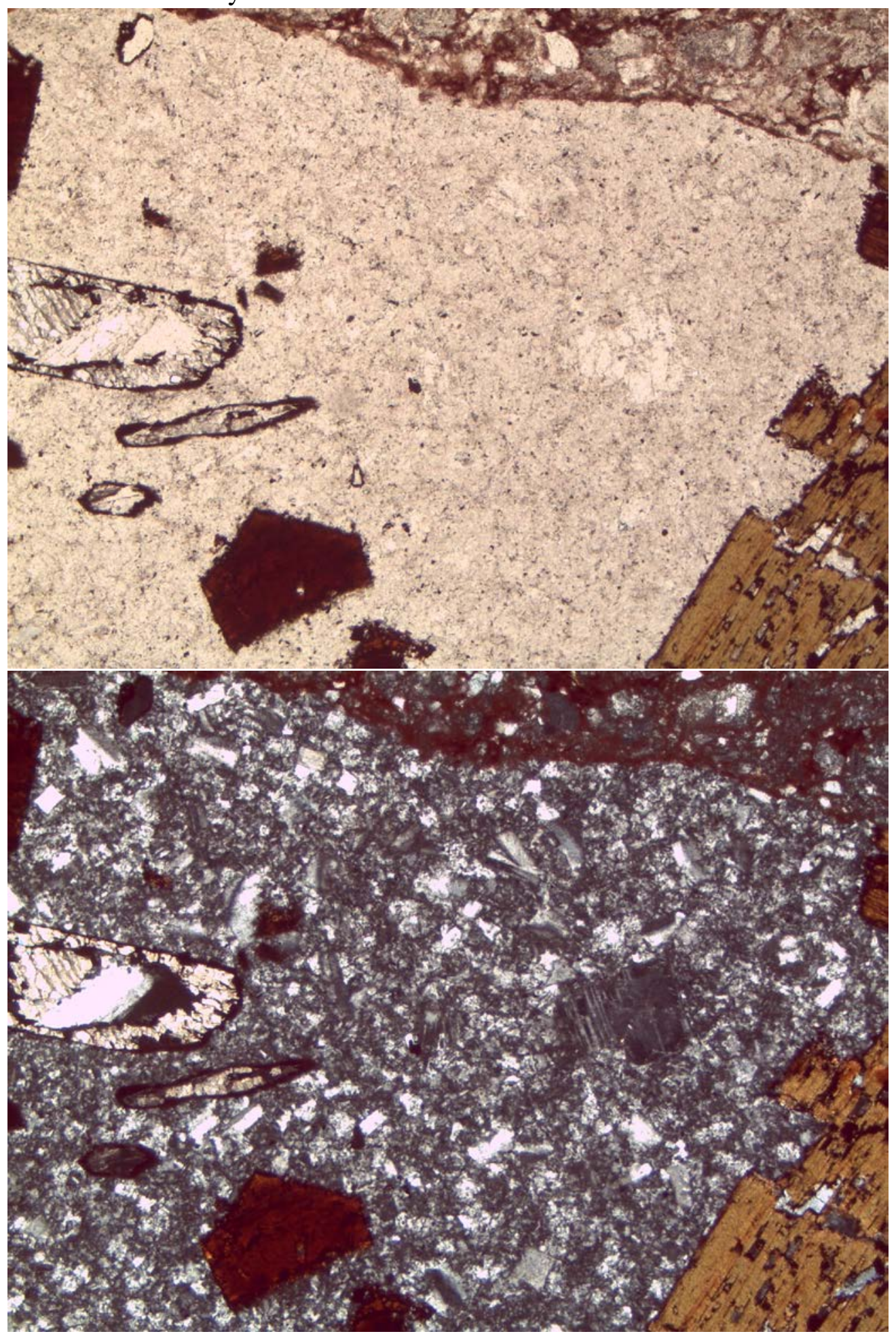

Width of field of view is $3 \mathrm{~mm}$. 
64A Thbi - Trachyandesite and Trachydacite dikes

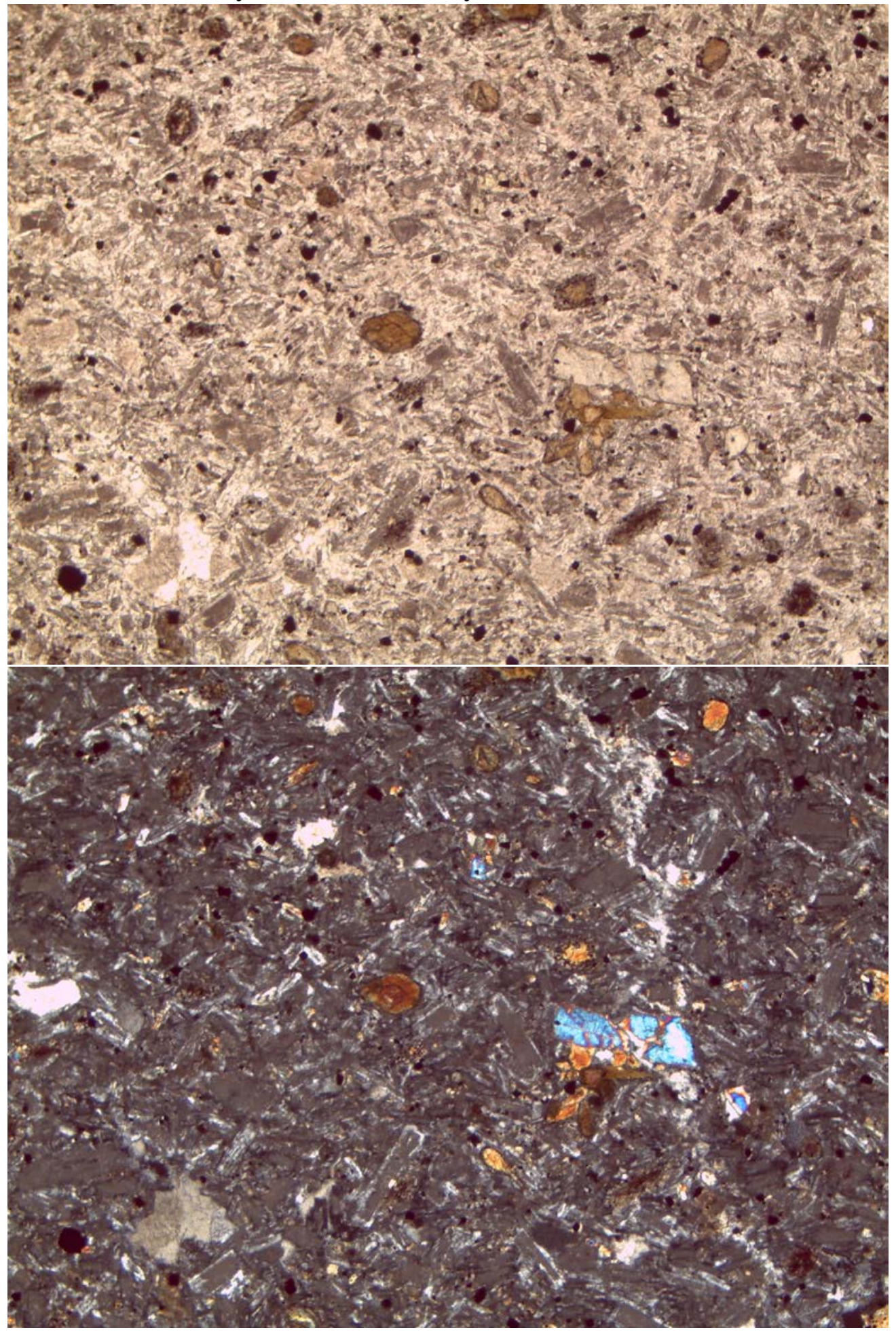

Width of field of view is $3 \mathrm{~mm}$. 
68B Thb - Volcanics of the Highland Range - trachyandesite flows

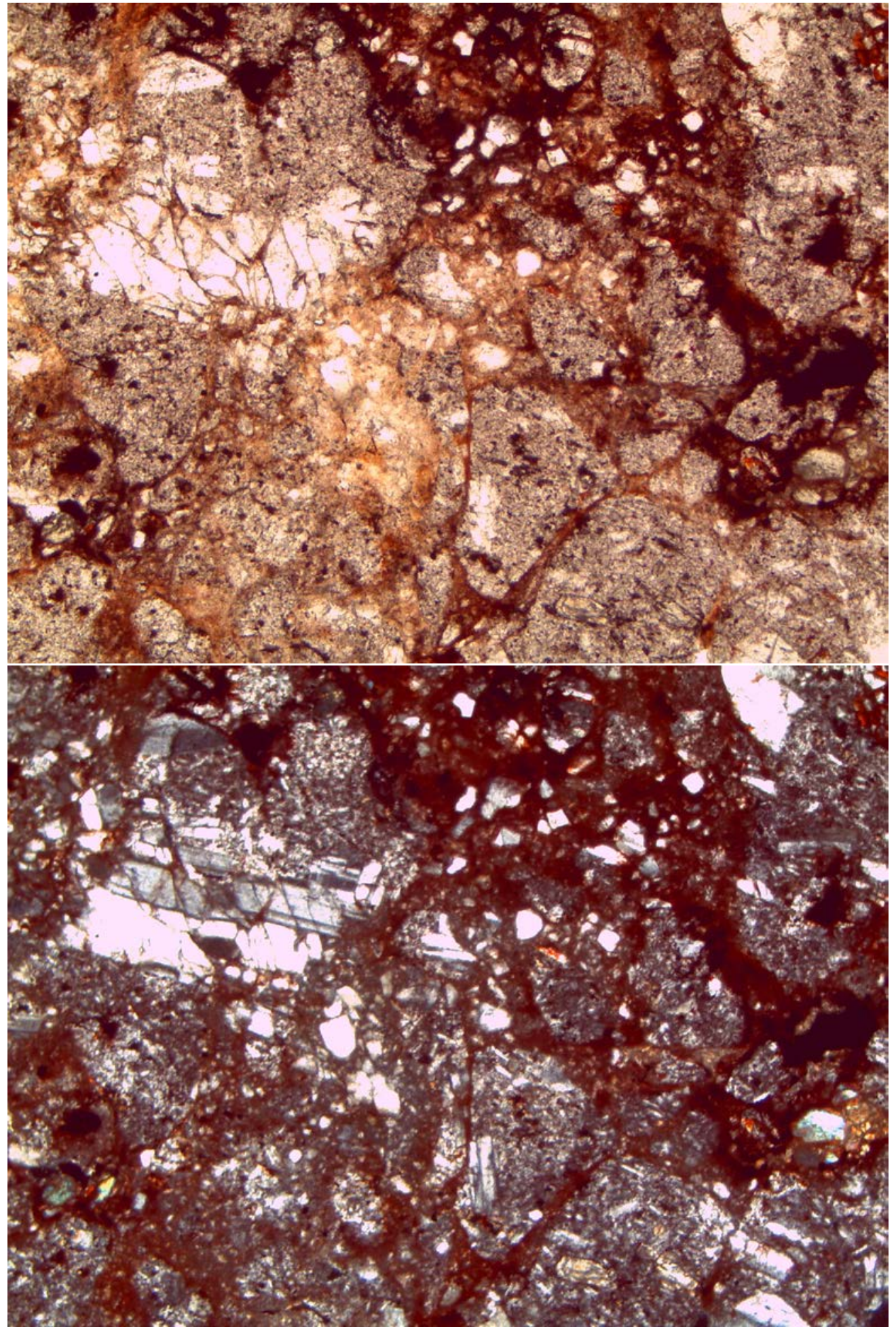

Width of field of view is $3 \mathrm{~mm}$. 
69A Thb - Volcanics of the Highland Range - trachyandesite flows

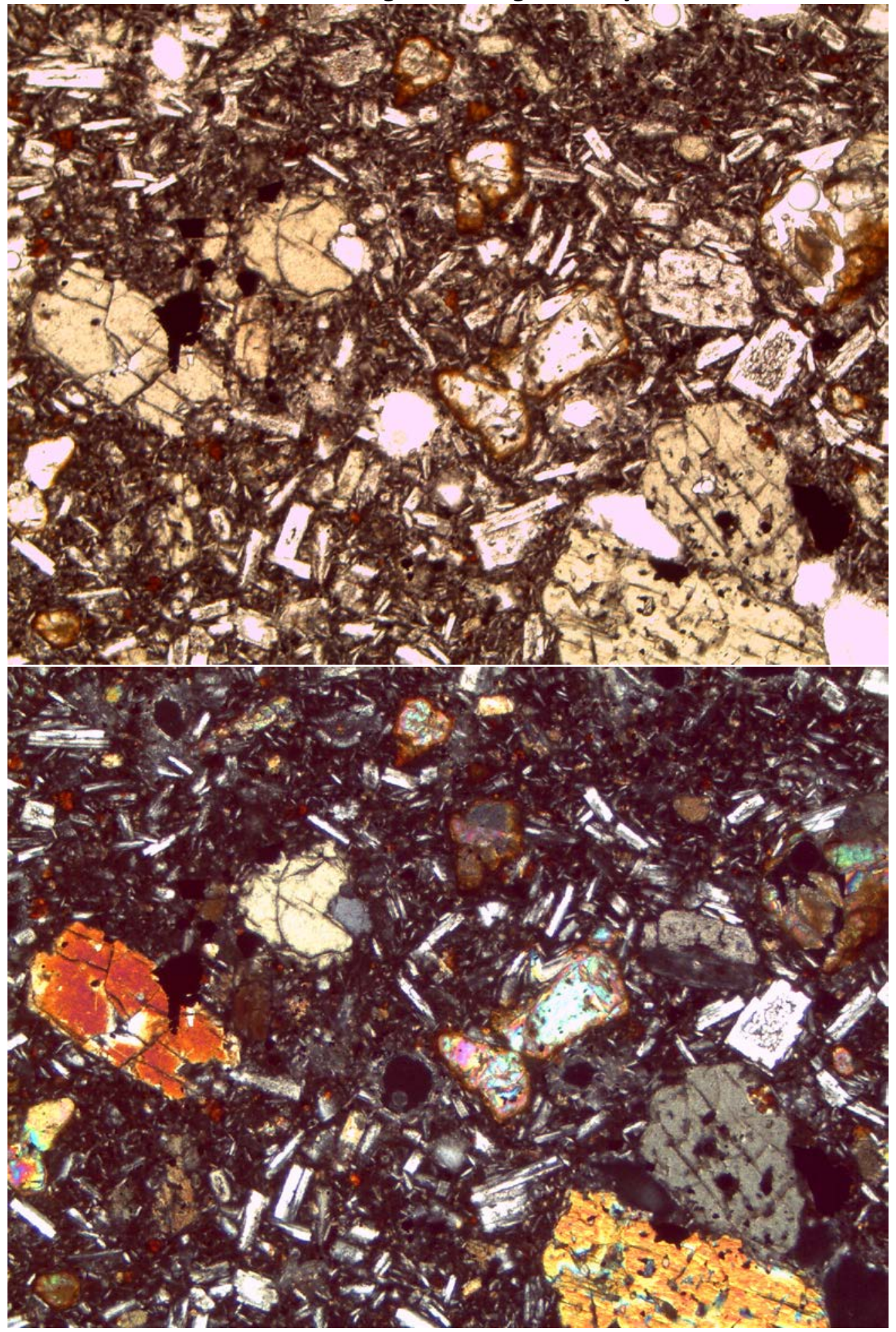

Width of field of view is $3 \mathrm{~mm}$. 
70D Tvb - Volcanic breccia: lithic tuff and debris flows

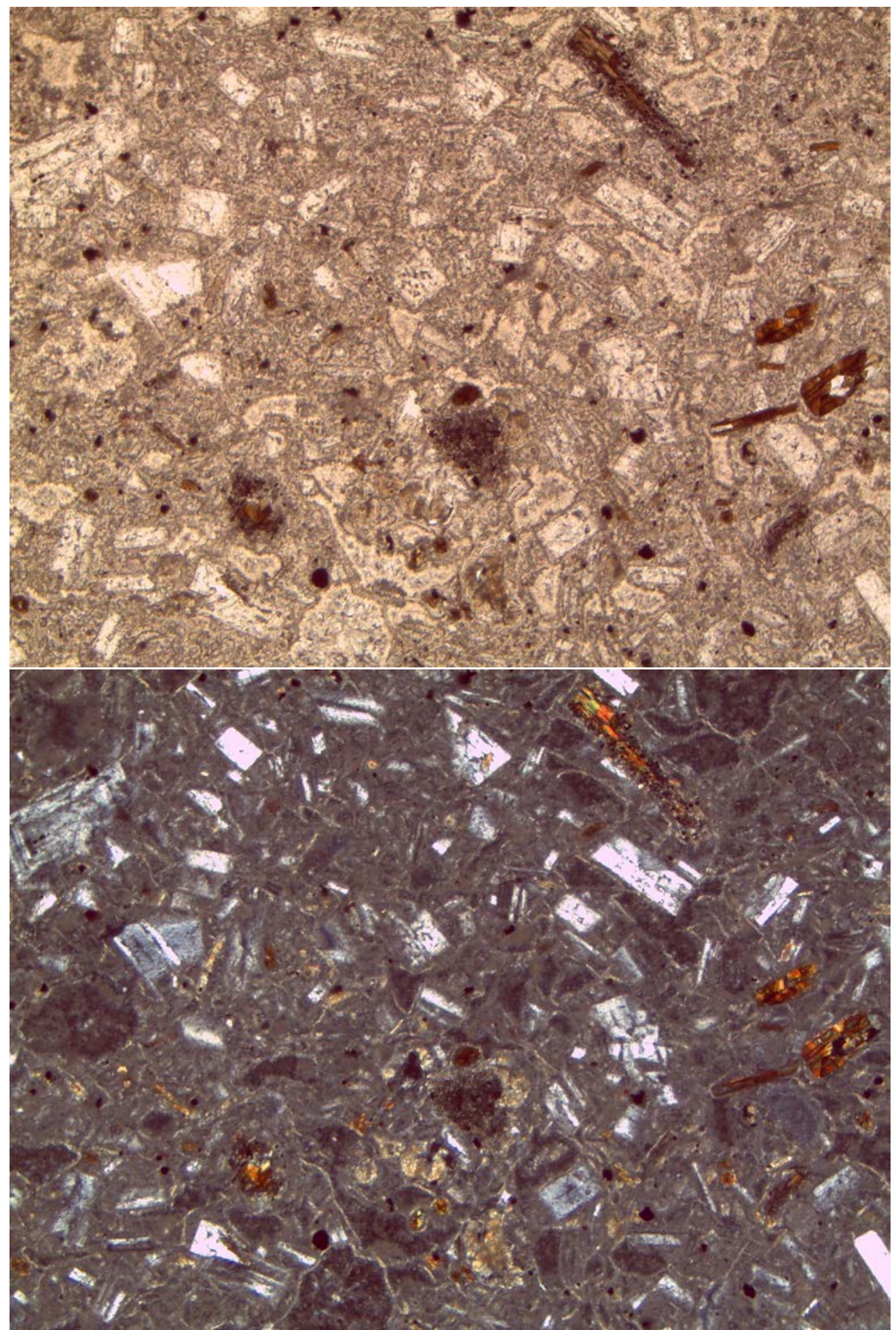

Width of field of view is $3 \mathrm{~mm}$. 
367A Xg-Diabase dike within Orthogneiss

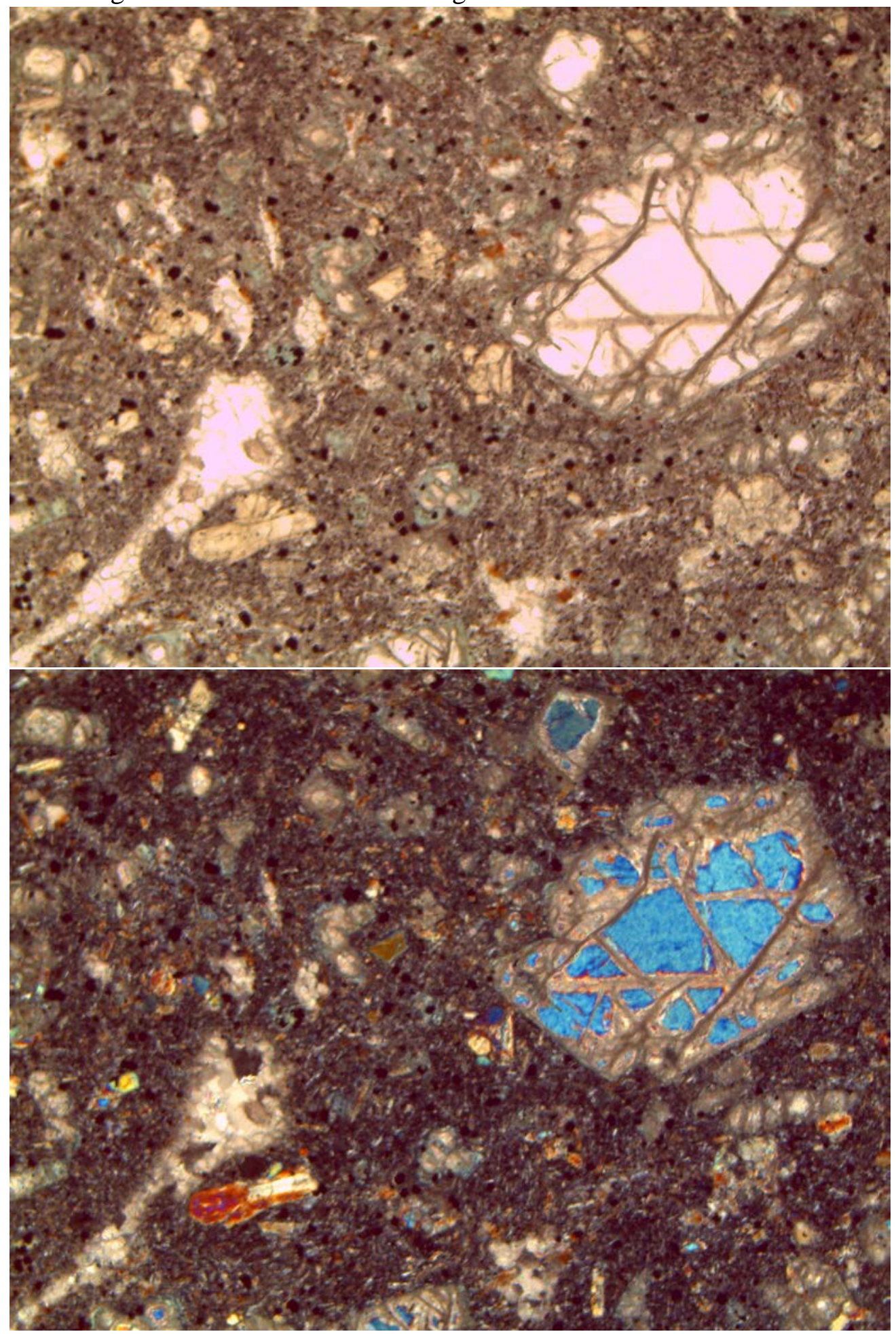

Width of field of view is $3 \mathrm{~mm}$. 


\section{APPENDIX B: Tables}

Table A. Modal Mineralogy in Selected Northern Highland Range Volcanic Units

Table B. Geochemical Data, Northern Highland Range, Nevada

Table C. Geochemical Data, Nelson SW Quadrangle, Highland Range, Nevada

Table D. Geochemical Data, silicic portion of the Highland Range, Nevada

Table E. Summary of Geochemistry for Volcanic Rocks of the McCullough Range 
Table A

Modal Mineralogy in Selected Northern Highland Range Volcanic Units

\begin{tabular}{|c|c|c|c|c|c|c|c|c|c|c|c|}
\hline 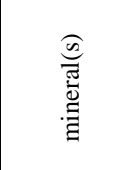 & 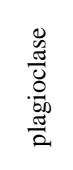 & 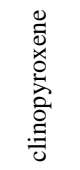 & 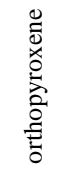 & 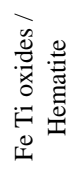 & 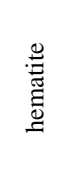 & 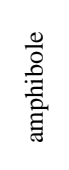 & $\begin{array}{l}\stackrel{\mathscr{Z}}{0} \\
.0 \\
.0\end{array}$ & 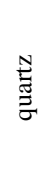 & $\begin{array}{l}\stackrel{\mathscr{\Xi}}{0} \\
\frac{0}{\partial}\end{array}$ & $\stackrel{\Xi}{\Xi}$ & 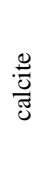 \\
\hline \multicolumn{12}{|l|}{ Thbi } \\
\hline $64 \mathrm{~A}$ & trace & 3 & --- & --- & --- & 5 & 2 & --- & --- & -- & -- \\
\hline $48 \mathrm{~A}$ & 2 & 5 & 4 & 2 & --- & --- & --- & --- & --- & -- & $\ldots$ \\
\hline $9 \mathrm{~A} / \mathrm{B}$ & 18 & 6 & 3 & --- & --- & 3 & 1 & --- & -- & -- & - \\
\hline \multicolumn{12}{|c|}{ Thb (upper) } \\
\hline 6 & 30 & 8 & --- & 1 & --- & 2 & --- & --- & --- & -- & - \\
\hline $69 \mathrm{~A}$ & 20 & 7 & 2 & 1 & --- & --- & --- & --- & --- & --- & -- \\
\hline $201 \mathrm{~A}$ & 23 & 6 & 4 & 1 & trace & --- & --- & --- & --- & --- & - \\
\hline $2 \mathrm{~B}$ & 5 & 7 & 2 & --- & --- & trace & trace & --- & --- & -- & - \\
\hline $70 \mathrm{~A}$ & 35 & 25 & --- & 3 & --- & 2 & --- & --- & -- & -- & - \\
\hline 41 & 20 & 4 & 7 & --- & --- & --- & --- & --- & --- & -- & - \\
\hline \multicolumn{12}{|c|}{ Tvb (matrix) } \\
\hline $3 \mathrm{~A}$ & trace & trace & trace & --- & --- & --- & --- & --- & trace & -- & -- \\
\hline $8 \mathrm{~B}$ & 25 & 5 & trace & --- & --- & --- & --- & --- & --- & --- & - \\
\hline $10 \mathrm{~A}$ & 25 & 5 & --- & trace & --- & trace & 4 & --- & --- & -- & -- \\
\hline 52 B & 14 & 12 & 9 & --- & --- & 7 & --- & --- & --- & -- & - \\
\hline $70 \mathrm{D}$ & 30 & 3 & -- & trace & -- & 3 & --- & --- & --- & -- & - \\
\hline $229 \mathrm{~A}$ & 20 & 2 & 1 & trace & --- & 5 & trace & --- & --- & -- & - \\
\hline \multicolumn{12}{|c|}{ Trachitic domes within Tvb } \\
\hline $68 \mathrm{~B}$ & 20 & 6 & 5 & --- & --- & --- & --- & --- & --- & --- & -- \\
\hline $66 \mathrm{~A}$ & 15 & 5 & trace & --- & -- & -- & --- & --- & --- & --- & -- \\
\hline \multicolumn{12}{|c|}{ Tvb (lithics) } \\
\hline $3 \mathrm{~A}$ & 25 & 4 & trace & --- & --- & --- & trace & --- & --- & --- & - \\
\hline $8 \mathrm{~B}$ & 25 & 5 & --- & --- & --- & 2 & --- & --- & --- & -- & - \\
\hline RAM $10 \mathrm{~A}$ & 25 & 5 & --- & trace & -- & trace & 4 & --- & -- & --- & - \\
\hline 52 B & 30 & 15 & --- & --- & --- & 5 & --- & --- & --- & --- & - \\
\hline $78 \mathrm{~A}$ & 5 & trace & --- & --- & -- & 3 & --- & --- & --- & -- & -- \\
\hline \multicolumn{12}{|c|}{ Thb (middle) } \\
\hline $52 \mathrm{~A}$ & 5 & 8 & 6 & --- & --- & --- & --- & --- & --- & -- & - \\
\hline $305 \mathrm{~A}$ & 20 & 7 & 4 & 4 & -- & 1 & -- & --- & -- & -- & - \\
\hline $78 \mathrm{~B}$ & 20 & 10 & trace & --- & --- & --- & --- & --- & --- & --- & $\cdots$ \\
\hline \multicolumn{12}{|l|}{ Thb (lower) } \\
\hline $305 \mathrm{~A}$ & 20 & 7 & 4 & 4 & 10 & 1 & --- & --- & $\begin{array}{l}-- \\
\end{array}$ & --- & - \\
\hline $19 \mathrm{~B}$ & 45 & 8 & 5 & trace & --- & -- & --- & --- & -- & -- & - \\
\hline $228 \mathrm{~A}$ & 15 & 3 & 2 & 1 & --- & 1 & 2 & --- & --- & -- & $\cdots$ \\
\hline RAM 11 A & 8 & trace & 4 & trace & -- & --- & --- & --- & -- & -- & - \\
\hline $105 \mathrm{~A}$ & 15 & 6 & 3 & 2 & --- & --- & --- & --- & --- & -- & - \\
\hline \multicolumn{12}{|l|}{ Thd } \\
\hline 362 B & 35 & trace & --- & --- & --- & 10 & --- & 1 & --- & --- & $\cdots$ \\
\hline $14 \mathrm{~A}$ & 25 & --- & --- & --- & -- & 8 & 8 & --- & --- & -- & - \\
\hline $56 \mathrm{~A}$ & 20 & --- & --- & --- & --- & 5 & --- & --- & --- & --- & -- \\
\hline $58 \mathrm{~A}$ & 12 & --- & --- & --- & --- & 5 & 7 & --- & --- & -- & -- \\
\hline \multicolumn{12}{|l|}{ Thbb } \\
\hline $98 \mathrm{~A}$ & --- & 5 & 5 & 3 & trace & --- & --- & --- & --- & -- & 3 \\
\hline \multicolumn{12}{|l|}{ Xg (dike) } \\
\hline $367 \mathrm{~A}$ & --- & 15 & --- & 5 & --- & --- & --- & --- & --- & 20 & - \\
\hline
\end{tabular}

(McKee, 2016) 
Table B

Geochemical Data, Northern Highland Range, Nevada

\begin{tabular}{|c|c|c|c|c|c|c|c|c|c|c|c|}
\hline Sample \# & & HR105A & HR98A & HR201A & HR78A & HR305A & HR228A & RAM9A & HR362B & RAM14A & HR229A \\
\hline Latitude & & 676656 & 675808 & 679277 & 677902 & 678217 & 677394 & 678784 & 676540 & 675704 & 677763 \\
\hline Longitude & & 3945872 & 3945831 & 3950049 & 3943521 & 3945332 & 3948320 & 3949393 & 3945605 & 3944897 & 3948662 \\
\hline Map Unit & & Thb & Thbb & Thb & Tvb (clast) & Thb & Thb & Thbi & Thd & Thd & Tvb \\
\hline \multicolumn{12}{|c|}{ Normalized Major Elements (Weight \%) } \\
\hline $\mathrm{SiO2}$ & & 58.02 & 58.03 & 59.65 & 60.65 & 61.28 & 61.62 & 63.98 & 65.77 & 66.70 & 70.34 \\
\hline TiO2 & & 0.963 & 0.927 & 1.138 & 0.698 & 0.944 & 0.824 & 0.730 & 0.548 & 0.524 & 0.597 \\
\hline Al2O3 & & 17.45 & 15.63 & 16.43 & 17.88 & 17.43 & 16.48 & 15.44 & 16.15 & 16.29 & 13.77 \\
\hline $\mathrm{FeO}^{*}$ & & 5.42 & 5.73 & 5.66 & 4.38 & 5.04 & 4.65 & 4.14 & 3.37 & 3.28 & 3.49 \\
\hline MnO & & 0.138 & 0.105 & 0.093 & 0.090 & 0.085 & 0.067 & 0.060 & 0.055 & 0.044 & 0.073 \\
\hline MgO & & 3.15 & 5.32 & 3.77 & 3.31 & 1.70 & 2.91 & 2.05 & 1.68 & 1.46 & 2.07 \\
\hline $\mathrm{CaO}$ & & 5.13 & 6.38 & 5.62 & 4.83 & 4.63 & 4.57 & 4.26 & 3.70 & 2.93 & 4.23 \\
\hline $\mathrm{Na2O}$ & & 4.57 & 3.94 & 4.08 & 3.11 & 4.36 & 4.16 & 3.31 & 4.18 & 4.51 & 2.07 \\
\hline K2O & & 4.54 & 3.41 & 3.06 & 4.76 & 4.06 & 4.30 & 5.65 & 4.24 & 3.97 & 3.12 \\
\hline P2O5 & & 0.624 & 0.539 & 0.499 & 0.292 & 0.478 & 0.423 & 0.370 & 0.306 & 0.281 & 0.225 \\
\hline $\mathrm{Na2O}+\mathrm{K} 2 \mathrm{O}$ & & 9.11 & 7.35 & 7.14 & 7.87 & 8.42 & 8.46 & 8.97 & 8.41 & 8.48 & 5.20 \\
\hline Total & & 100.00 & 100.00 & 100.00 & 100.00 & 100.00 & 100.00 & 100.00 & 100.00 & 100.00 & 100.00 \\
\hline \multicolumn{12}{|c|}{ Trace Elements (ppm) } \\
\hline \multirow[t]{2}{*}{ Sc } & & 11 & 13 & 11 & 8 & 9 & 10 & 8 & 8 & 6 & 7 \\
\hline & Sc & 11.5 & 14.8 & 12.4 & 8.4 & 10.1 & 10.2 & 8.8 & 7.4 & 7.2 & 7.4 \\
\hline $\mathbf{V}$ & & 155 & 107 & 116 & 111 & 90 & 106 & 83 & 74 & 67 & 57 \\
\hline $\mathrm{Cr}$ & & 63 & 193 & 64 & 32 & 38 & 67 & 53 & 42 & 42 & 44 \\
\hline $\mathrm{Ni}$ & & 52 & 156 & 53 & 23 & 34 & 43 & 37 & 27 & 36 & 31 \\
\hline $\mathrm{Cu}$ & & 100 & 30 & 31 & 16 & 30 & 41 & 28 & 20 & 11 & 14 \\
\hline Zn & & 89 & 75 & 86 & 89 & 83 & 68 & 66 & 63 & 60 & 56 \\
\hline Ga & & 24 & 22 & 20 & 23 & 22 & 22 & 19 & 22 & 20 & 16 \\
\hline \multirow[t]{2}{*}{$\mathbf{R b}$} & & 136 & 70 & 143 & 93 & 96 & 128 & 114 & 97 & 84 & 59 \\
\hline & $\mathbf{R b}$ & 134.4 & 68.4 & 139.6 & 91.6 & 94.4 & 126.5 & 112.7 & 97.1 & 83.2 & 58.6 \\
\hline \multirow[t]{2}{*}{$\mathrm{Sr}$} & & 1411 & 1350 & 1149 & 1492 & 1139 & 1278 & 859 & 998 & 1243 & 1178 \\
\hline & $\mathrm{Sr}$ & 1491 & 1440 & 1203 & 1560 & 1210 & 1349 & 898 & 1068 & 1317 & 1237 \\
\hline \multirow[t]{2}{*}{$\mathbf{Y}$} & & 24 & 22 & 22 & 15 & 21 & 20 & 18 & 15 & 12 & 13 \\
\hline & $\mathbf{Y}$ & 24.70 & 21.99 & 21.32 & 15.82 & 22.22 & 19.84 & 18.23 & 15.02 & 12.64 & 13.43 \\
\hline \multirow[t]{2}{*}{$\mathrm{Zr}$} & & 501 & 318 & 288 & 277 & 371 & 353 & 290 & 213 & 224 & 203 \\
\hline & $\mathrm{Zr}$ & 534 & 335 & 293 & 277 & 394 & 372 & 299 & 215 & 231 & 203 \\
\hline
\end{tabular}


Table B (continued)

Geochemical Data, Northern Highland Range, Nevada

\begin{tabular}{|c|c|c|c|c|c|c|c|c|c|c|}
\hline $\begin{array}{l}\text { Sample \# } \\
\text { Map Unit }\end{array}$ & $\begin{array}{c}\text { HR105A } \\
\text { Thb }\end{array}$ & $\begin{array}{c}\text { HR98A } \\
\text { Thbb }\end{array}$ & $\begin{array}{c}\text { HR201A } \\
\text { Thb }\end{array}$ & $\begin{array}{c}\text { HR78A } \\
\text { Tvb (clast) }\end{array}$ & $\begin{array}{c}\text { HR305A } \\
\text { Thb }\end{array}$ & $\begin{array}{c}\text { HR228A } \\
\text { Thb }\end{array}$ & $\begin{array}{c}\text { RAM9A } \\
\text { Thbi }\end{array}$ & $\begin{array}{l}\text { HR362B } \\
\text { Thd }\end{array}$ & $\begin{array}{c}\text { RAM14A } \\
\text { Thd }\end{array}$ & $\begin{array}{c}\text { HR229A } \\
\text { Tvb }\end{array}$ \\
\hline \multirow[t]{3}{*}{ Nb } & 30.9 & 20.8 & 22.7 & 13.3 & 23.3 & 22.7 & 17.5 & 11.9 & 13.0 & 12.2 \\
\hline & 30.45 & 20.37 & 22.75 & 12.66 & 22.99 & 22.63 & 17.52 & 11.28 & 12.67 & 11.24 \\
\hline & 3.94 & 0.72 & 1.26 & 1.09 & 1.29 & 2.10 & 0.73 & 0.76 & 0.91 & 1.20 \\
\hline \multirow[t]{2}{*}{ Ba } & 1822 & 1532 & 1403 & 1932 & 1634 & 1686 & 1404 & 1523 & 1760 & 1407 \\
\hline & 1933 & 1610 & 1491 & 2042 & 1731 & 1793 & 1465 & 1626 & 1858 & 1482 \\
\hline \multirow[t]{2}{*}{ La } & 122 & 77 & 70 & 58 & 81 & 87 & 70 & 50 & 66 & 44 \\
\hline & 138.13 & 84.18 & 73.78 & 59.31 & 87.15 & 99.64 & 77.16 & 54.70 & 70.18 & 46.46 \\
\hline \multirow[t]{3}{*}{ Ce } & 237 & 158 & 136 & 117 & 152 & 178 & 137 & 104 & 122 & 85 \\
\hline & 256.87 & 171.49 & 147.36 & 125.44 & 163.89 & 195.33 & 149.65 & 108.83 & 133.14 & 90.13 \\
\hline & 28.26 & 19.58 & 16.34 & 14.10 & 18.19 & 21.44 & 15.97 & 11.93 & 14.29 & 9.91 \\
\hline \multirow[t]{14}{*}{ Nd } & 94 & 68 & 54 & 48 & 62 & 72 & 54 & 41 & 45 & 33 \\
\hline & 99.22 & 71.79 & 59.55 & 50.41 & 63.90 & 75.40 & 55.93 & 42.85 & 49.94 & 35.34 \\
\hline & 15.65 & 11.64 & 9.66 & 8.13 & 9.81 & 11.88 & 8.61 & 7.10 & 7.66 & 5.72 \\
\hline & 3.39 & 2.77 & 2.36 & 2.05 & 2.34 & 2.59 & 1.96 & 1.68 & 1.80 & 1.37 \\
\hline & 9.75 & 7.52 & 6.73 & 5.05 & 6.70 & 7.41 & 5.56 & 4.71 & 4.58 & 3.92 \\
\hline & 1.17 & 0.95 & 0.88 & 0.65 & 0.88 & 0.89 & 0.73 & 0.61 & 0.57 & 0.53 \\
\hline & 5.56 & 4.77 & 4.65 & 3.44 & 4.62 & 4.42 & 3.77 & 3.12 & 2.74 & 2.81 \\
\hline & 0.94 & 0.82 & 0.84 & 0.62 & 0.84 & 0.76 & 0.70 & 0.56 & 0.48 & 0.52 \\
\hline & 2.26 & 2.02 & 2.09 & 1.58 & 2.16 & 1.84 & 1.77 & 1.43 & 1.20 & 1.31 \\
\hline & 0.30 & 0.27 & 0.29 & 0.22 & 0.30 & 0.25 & 0.25 & 0.20 & 0.17 & 0.18 \\
\hline & 1.86 & 1.65 & 1.76 & 1.35 & 1.86 & 1.55 & 1.59 & 1.23 & 1.04 & 1.13 \\
\hline & 0.27 & 0.25 & 0.26 & 0.21 & 0.28 & 0.23 & 0.24 & 0.19 & 0.16 & 0.17 \\
\hline & 11.65 & 7.76 & 7.01 & 6.86 & 8.76 & 8.70 & 7.22 & 5.54 & 5.84 & 5.20 \\
\hline & 1.61 & 1.06 & 1.39 & 0.73 & 1.39 & 1.31 & 1.12 & 0.64 & 0.70 & 0.69 \\
\hline \multirow[t]{2}{*}{$\mathbf{P b}$} & 35 & 22 & 18 & 21 & 23 & 30 & 20 & 26 & 27 & 17 \\
\hline & 35.76 & 21.74 & 18.44 & 20.96 & 24.29 & 30.43 & 24.22 & 25.64 & 27.21 & 17.22 \\
\hline \multirow[t]{2}{*}{ Th } & 40 & 12 & 12 & 14 & 14 & 30 & 16 & 11 & 13 & 8 \\
\hline & 41.12 & 11.57 & 10.98 & 13.82 & 14.28 & 30.74 & 16.86 & 11.32 & 13.41 & 8.40 \\
\hline \multirow[t]{2}{*}{$\mathbf{U}$} & 7 & 3 & 2 & 2 & 4 & 6 & 3 & 2 & 5 & 1 \\
\hline & 8.57 & 2.09 & 2.02 & 1.76 & 2.54 & 6.06 & 3.09 & 1.99 & 2.32 & 1.20 \\
\hline
\end{tabular}

Major and trace element data were analyzed at the GeoAnalytical Laboratory at Washington State University. Major and trace elements (not shaded) were measured by XRF (x-ray flourescence), except trace elements (shaded) were analyzed on an ICP-mass spectrometer. See geologic map and Unit Description section for description of units. Locations are in UTM, zone 11 S.

(McKee, 2016) 
Table C

Geochemical Data, Nelson SW Quadrangle, Highland Range, Nevada

\begin{tabular}{|c|c|c|c|c|c|c|c|c|c|c|c|}
\hline & & & & & & & & & & & \\
\hline Sample \# & JF-94-61 & JF-94-62 & JF-94-63 & JF-94-64 & JF-99-83 & JF-99-89 & JF-99-141 & JF-99-151 & JF-99-235 & JF-99-252 & JF-99-265 \\
\hline Latitude & 35³1’29" & 35³1’43" & 35³2’11" & 35³2’39" & 35³1’04" & $35^{\circ} 31^{\prime} 27^{\prime \prime}$ & $35^{\circ} 30^{\prime} 00^{\prime \prime}$ & $35^{\circ} 30^{\prime} 04^{\prime \prime}$ & $35^{\circ} 31^{\prime} 52^{\prime \prime}$ & 35³2’36" & 35³3’58" \\
\hline Age (Ma) & 16.26 & 16.21 & 15.98 & 15.66 & & & & & & & \\
\hline & & & & Maj & jor Elemen & ts (Weight & $\%)$ & & & & \\
\hline $\mathrm{SiO}_{2}$ & 67.41 & 69.72 & 57.94 & 57.23 & 62.5 & 63.56 & 63.61 & 63.08 & 60.16 & 65.16 & 68.05 \\
\hline $\mathrm{FeO}^{*}$ & 2.58 & 1.47 & 4.86 & 5.2 & 4.85 & 3.88 & 4.16 & 4.38 & 4.5 & 4.11 & 3.43 \\
\hline MnO & 0.074 & 0.089 & 0.094 & 0.097 & 0.074 & 0.058 & 0.063 & 0.042 & 0.059 & 0.082 & 0.065 \\
\hline MgO & 0.91 & 0.46 & 4.86 & 4.70 & 3.18 & 2.24 & 2.92 & 3.09 & 3.70 & 2.96 & 1.54 \\
\hline $\mathrm{CaO}$ & 2.16 & 1.16 & 6.40 & 7.05 & 4.26 & 3.78 & 4.26 & 4.33 & 5.43 & 4.21 & 3.25 \\
\hline $\mathrm{Na}_{2} \mathrm{O}$ & 4.30 & 4.49 & 3.79 & 4.01 & 3.73 & 2.91 & 3.66 & 3.70 & 3.39 & 3.68 & 3.70 \\
\hline $\mathrm{K}_{2} \mathrm{O}$ & 4.87 & 5.51 & 3.94 & 3.40 & 3.72 & 5.67 & 3.70 & 4.61 & 5.64 & 3.85 & 4.37 \\
\hline
\end{tabular}

\begin{tabular}{|c|c|c|c|c|c|c|c|c|c|c|c|}
\hline Total & 98.75 & 98.52 & 99.34 & 99.43 & 98.73 & 98.95 & 98.79 & 99.42 & 99.27 & 99.19 & 99.48 \\
\hline $\mathrm{V}$ & 42 & 10 & 134 & 140 & 127 & 67 & 86 & 71 & 117 & 82 & 78 \\
\hline $\mathrm{Ni}$ & 11 & 10 & 92 & 87 & 61 & 50 & 56 & 102 & 125 & 59 & 54 \\
\hline $\mathrm{Cu}$ & 8 & 5 & 34 & 37 & 20 & 20 & 25 & 23 & 42 & 34 & 24 \\
\hline $\mathrm{Zn}$ & 62 & 63 & 79 & 76 & 76 & 62 & 73 & 63 & 82 & 56 & 47 \\
\hline $\mathrm{Sr}$ & 452 & 131 & 1188 & 1182 & 1066 & 963 & 942 & 1138 & 1337 & 600 & 578 \\
\hline $\mathrm{Y}$ & 24.93 & 32.01 & 23.78 & 23.70 & 19 & 18 & 19 & 21 & 22 & 22 & 24 \\
\hline $\mathrm{Zr}$ & 346 & 404 & 316 & 300 & 276 & 305 & 266 & 314 & 459 & 238 & 259 \\
\hline $\mathrm{Nb}$ & 26.78 & 34.47 & 20.95 & 20.58 & 14.2 & 18.1 & 14.0 & 16.9 & 21.8 & 21.4 & 24.7 \\
\hline Cs & 2.75 & 5.78 & 2.07 & 1.00 & & & & & & & \\
\hline $\mathrm{Nd}$ & 48.36 & 61.02 & 66.70 & 62.37 & & & & & & & \\
\hline $\mathrm{Sm}$ & 7.96 & 10.06 & 12.28 & 11.24 & & & & & & & \\
\hline $\mathrm{Eu}$ & 1.86 & 2.00 & 3.02 & 2.81 & & & & & & & \\
\hline $\mathrm{Gd}$ & 5.37 & 6.81 & 7.81 & 7.32 & & & & & & & \\
\hline $\mathrm{Tb}$ & 0.82 & 1.05 & 1.03 & 1.00 & & & & & & & \\
\hline Dy & 4.52 & 5.86 & 4.99 & 4.92 & & & & & & & \\
\hline Ho & 0.86 & 1.13 & 0.86 & 0.87 & & & & & & & \\
\hline Er & 2.33 & 3.09 & 2.12 & 2.14 & & & & & & & \\
\hline $\mathrm{Tm}$ & 0.33 & 0.43 & 0.28 & 0.29 & & & & & & & \\
\hline $\mathrm{Yb}$ & 2.12 & 2.84 & 1.69 & 1.69 & & & & & & & \\
\hline $\mathrm{Lu}$ & 0.34 & 0.44 & 0.25 & 0.25 & & & & & & & \\
\hline $\mathrm{Hf}$ & 8.03 & 10.20 & 7.83 & 7.09 & & & & & & & \\
\hline & \multicolumn{11}{|c|}{-9.63} \\
\hline & \multicolumn{11}{|c|}{17.806} \\
\hline & \multicolumn{11}{|c|}{15.538} \\
\hline & \multicolumn{11}{|c|}{38.441} \\
\hline
\end{tabular}

Major and trace element data were analyzed at the GeoAnalytical Laboratory at Washington State University. Trace elements were measured by XRF (x-ray fluorescence), except samples 94-61, 94-62, 94-63, and 94-64. For these samples, Rb, Y, Nb, Cs, Ba, La, Ce, Pr, Nd, Sm, Eu, Gd, Tb, Dy, Ho, Er, Tm, Yb, Lu, Hf, $\mathrm{Ta}, \mathrm{Pb}, \mathrm{Th}$, and $\mathrm{U}$ were analyzed on an ICP-mass spectrometer. Isotopic compositions were completed at the University of Kansas. See Geologic Map of the Nelson SW Quadrangle for descriptions of units.

(Faulds et al., 2002a) 
Table D

Geochemical Data, silicic portion of the Highland Range, Nevada

\begin{tabular}{|c|c|c|c|c|c|}
\hline Sample \# & HRL 14A & HRL 12A & HRL 16 & HRL 21 & HRL 27 \\
\hline Age (Ma) & 16.0 & 16.0 & --- & --- & $16.3-16.6$ \\
\hline Map Unit & Thr & Thr & Thb & Thb & Thla \\
\hline \multicolumn{6}{|c|}{ Major Elements (Weight \%) } \\
\hline $\mathrm{SiO2}$ & 65.54 & 72.59 & 76.62 & 77.40 & 67.90 \\
\hline $\mathrm{TiO} 2$ & 14.53 & 13.51 & 12.12 & 12.45 & 15.86 \\
\hline Al2O3 & 4.51 & 2.13 & 2.01 & 0.69 & 3.11 \\
\hline FeO* & 0.08 & 0.05 & 0.05 & 0.04 & 0.08 \\
\hline MnO & 2.76 & 0.76 & 0.20 & 0.10 & 0.89 \\
\hline MgO & 4.21 & 1.47 & 0.50 & 0.64 & 2.21 \\
\hline $\mathrm{CaO}$ & 3.41 & 3.27 & 2.81 & 2.64 & 4.96 \\
\hline Na2O & 3.88 & 5.69 & 5.55 & 5.92 & 4.18 \\
\hline K2O & 0.79 & 0.40 & 0.10 & 0.12 & 0.64 \\
\hline P2O5 & 0.30 & 0.12 & 0.02 & 0.01 & 0.17 \\
\hline $\mathrm{Na} 2 \mathrm{O}+\mathrm{K} 2 \mathrm{O}$ & 4.67 & 6.09 & 5.65 & 6.04 & 4.82 \\
\hline Total & 98.90 & 99.56 & 100.90 & 98.85 & 100.50 \\
\hline \multicolumn{6}{|c|}{ Trace Elements (ppm) } \\
\hline \multicolumn{6}{|l|}{ Sc } \\
\hline \multicolumn{6}{|l|}{$\mathrm{V}$} \\
\hline \multicolumn{6}{|l|}{$\mathrm{Cr}$} \\
\hline \multicolumn{6}{|l|}{$\mathrm{Ni}$} \\
\hline \multicolumn{6}{|l|}{$\mathrm{Cu}$} \\
\hline \multicolumn{6}{|l|}{$\mathrm{Zn}$} \\
\hline \multicolumn{6}{|l|}{ Ga } \\
\hline $\mathrm{Rb}$ & 119 & 155 & 184 & 202 & 146 \\
\hline $\mathrm{Sr}$ & 584 & 173 & 17 & 19 & 486 \\
\hline $\mathrm{Y}$ & 21 & 21 & 11.5 & 12 & 19 \\
\hline $\mathrm{Zr}$ & 260 & 210 & 82.5 & 91 & 405 \\
\hline $\mathrm{Nb}$ & 20 & 21.3 & 35.5 & 22.7 & 22.5 \\
\hline \multicolumn{6}{|l|}{ Cs } \\
\hline $\mathrm{Ba}$ & 797 & 525 & 29 & 33 & 1488 \\
\hline $\mathrm{La}$ & 56.0 & 58.9 & 31.0 & 35.7 & 72.1 \\
\hline $\mathrm{Ce}$ & 110.0 & 104.0 & 50.8 & 59.8 & 138.0 \\
\hline $\operatorname{Pr}$ & 13.1 & 10.1 & 4.2 & 5.5 & 16.1 \\
\hline $\mathrm{Nd}$ & 39.8 & 31.0 & 10.4 & 13.2 & 45.5 \\
\hline $\mathrm{Sm}$ & 7.24 & 5.78 & 1.37 & 2.08 & 8.06 \\
\hline $\mathrm{Eu}$ & 1.54 & 0.94 & 0.11 & 0.20 & 2.01 \\
\hline Gd & 5.25 & 4.03 & 1.18 & 1.41 & 5.61 \\
\hline $\mathrm{Tb}$ & 0.74 & 0.62 & 0.21 & 0.27 & 0.79 \\
\hline Dy & 4.11 & 3.62 & 1.43 & 1.81 & 4.36 \\
\hline Но & 0.83 & 0.73 & 0.35 & 0.42 & 0.84 \\
\hline $\mathrm{Er}$ & 2.39 & 2.20 & 1.24 & 1.47 & 2.47 \\
\hline $\mathrm{Tm}$ & 0.35 & 0.36 & 0.23 & 0.26 & 0.38 \\
\hline $\mathrm{Yb}$ & 2.16 & 2.25 & 1.77 & 1.77 & 2.36 \\
\hline $\mathrm{Lu}$ & 0.33 & 0.31 & 0.31 & 0.25 & 0.35 \\
\hline Hf & 6.8 & 5.8 & 3.85 & 3.6 & 9.5 \\
\hline \multicolumn{6}{|l|}{ Та } \\
\hline \multicolumn{6}{|l|}{$\mathrm{Pb}$} \\
\hline Th & 15.6 & 18.6 & 24.45 & 22.8 & 13.8 \\
\hline $\mathrm{U}$ & 5.53 & 3.16 & 4.815 & 18.1 & 3.12 \\
\hline
\end{tabular}

(Colombini et al., 2011) 
Table E

Summary of Geochemistry for Volcanic Rocks of the McCullough Range

\begin{tabular}{|c|c|c|c|c|c|c|c|c|c|c|c|c|c|c|}
\hline Sample \# & Tch-a1 & Tch-d2 & Tms-b3 & Tms-a4 & Tmw-d5 & Tmw-b6 & Tev-d7 & Tev-b8 & Tfr-a9 & Tfc-a10 & Tic-a11 & Tcd-b12 & Tcd-a13 & Tcd-d14 \\
\hline \multicolumn{15}{|c|}{ Major Elements (Weight \%) } \\
\hline $\mathrm{SiO} 2$ & 56.2 & 62.44 & 55.23 & 59.78 & 65.61 & 63.73 & 65.38 & 65.91 & 54.64 & 55.64 & 54.15 & 54.45 & 59.68 & 65.01 \\
\hline $\mathrm{Al} 2 \mathrm{O} 3$ & 15.97 & 15.8 & 18.44 & 18.37 & 15.89 & 16.17 & 15.68 & 15.63 & 16.25 & 16.4 & 15.06 & 16.28 & 16.27 & 16.12 \\
\hline $\mathrm{TiO} 2$ & 1.14 & 0.84 & 1.04 & 1.01 & 0.6 & 0.69 & 0.59 & 0.58 & 1.23 & 1.03 & 1.28 & 1.45 & 1.04 & 0.74 \\
\hline Fe2O3 & 6.85 & 4.75 & 6.46 & 5.18 & 3.91 & 4.46 & 3.92 & 3.83 & 7.17 & 6.18 & 6.26 & 7.87 & 5.6 & 4.03 \\
\hline $\mathrm{MgO}$ & 4.45 & 2.34 & 3.03 & 1.95 & 1.59 & 2.04 & 2.34 & 1.88 & 4.4 & 3.37 & 3.4 & 4.72 & 3.47 & 1.82 \\
\hline $\mathrm{Na} 2 \mathrm{O}$ & 3.77 & 3.92 & 3.92 & 4.3 & 4 & 3.94 & 3.69 & 3.76 & 3.25 & 3.23 & 3.45 & 3.63 & 3.65 & 3.91 \\
\hline K2O & 3.45 & 3.99 & 4.8 & 4.01 & 4.16 & 4.05 & 3.71 & 4.03 & 3.33 & 3.65 & 4.12 & 3.18 & 4.09 & 4.88 \\
\hline $\mathrm{MnO}$ & 0.1 & 0.06 & 0.11 & 0.09 & 0.06 & 0.08 & 0.06 & 0.06 & 0.11 & 0.1 & 0.2 & 0.12 & 0.1 & 0.06 \\
\hline $\mathrm{CaO}$ & 6.55 & 4.33 & 5 & 4.86 & 3.67 & 3.98 & 4.17 & 3.37 & 6.8 & 5.65 & 7.58 & 7.15 & 5.31 & 3.23 \\
\hline P2O5 & 0.57 & 0.38 & 1.09 & 0.44 & 0.27 & 0.34 & 0.25 & 0.24 & 0.65 & 0.55 & 0.57 & 0.69 & 0.51 & 0.31 \\
\hline $\mathrm{Na} 2 \mathrm{O}+\mathrm{K} 2 \mathrm{O}$ & 7.22 & 7.91 & 8.72 & 8.31 & 8.16 & 7.99 & 7.4 & 7.79 & 6.58 & 6.88 & 7.57 & 6.81 & 7.74 & 8.79 \\
\hline Total & 99.04 & 98.86 & 99.12 & 99.98 & 99.76 & 99.48 & 99.79 & 99.29 & 97.83 & 95.8 & 96.07 & 99.53 & 99.73 & 100.12 \\
\hline \multicolumn{15}{|c|}{ Trace Elements (ppm) } \\
\hline Sc & 15 & 11 & 10 & 11 & 8 & 9 & 10 & 8 & & & & 19 & 12 & 9 \\
\hline V & 162 & 109 & 164 & 106 & 70 & 81 & 73 & 64 & & & & 210 & 151 & 87 \\
\hline $\mathrm{Ni}$ & 71 & 34 & 21 & 10 & 17 & 19 & 32 & 26 & 58 & 21 & 80 & 44 & 37 & 17 \\
\hline $\mathrm{Cu}$ & 39 & 30 & 113 & 15 & 18 & 20 & 20 & 20 & & & & 41 & 33 & 19 \\
\hline Ga & 20 & 20 & 20 & 21 & 19 & 20 & 19 & 19 & & & & 20 & 19 & 18 \\
\hline $\mathrm{Rb}$ & 73 & 91 & 65 & 81 & 103 & 113 & 90 & 105 & 78 & 87 & 107 & 67 & 92 & 129 \\
\hline $\mathrm{Sr}$ & 1201 & 957 & 2828 & 1067 & 840 & 958 & 802 & 771 & 974 & 939 & 836 & 1133 & 1187 & 708 \\
\hline Y & 24 & 23 & 28 & 29 & 25 & 29 & 23 & 22 & 24 & 17 & 23 & 29 & 30 & 32 \\
\hline $\mathrm{Zr}$ & 374 & 350 & 762 & 415 & 317 & 343 & 280 & 284 & 347 & 351 & 406 & 434 & 448 & 418 \\
\hline $\mathrm{Nb}$ & 17 & 15 & 41 & 23 & 14 & 16 & 12 & 13 & 17 & 17 & 23 & 20 & 22 & 24 \\
\hline Ba & 1599 & 1523 & 2121 & 1578 & 1464 & 1509 & 1625 & 1488 & 1344 & 1507 & 1066 & 1713 & 1755 & 1481 \\
\hline $\mathrm{La}$ & 77 & 64 & 187 & 68 & 63 & 69 & 52 & 61 & 80 & 84 & 98 & 93 & 88 & 86 \\
\hline $\mathrm{Hf}$ & 10 & 10 & 20 & 11 & 9 & 10 & 7 & 8 & 8 & 8 & 10 & 11 & 12 & 11 \\
\hline $\mathrm{Pb}$ & 13 & 15 & 33 & 13 & 18 & 16 & 16 & 20 & & & & 12 & 21 & 20 \\
\hline Th & 21 & 20 & 69 & 20 & 19 & 21 & 16 & 15 & 14 & 14 & 24 & 25 & 29 & 27 \\
\hline $\mathrm{U}$ & 2 & 2 & 0 & 0 & 3 & 2 & 0 & 4 & & & & 1 & 0 & 2 \\
\hline
\end{tabular}

(Smith et al., 2010) 